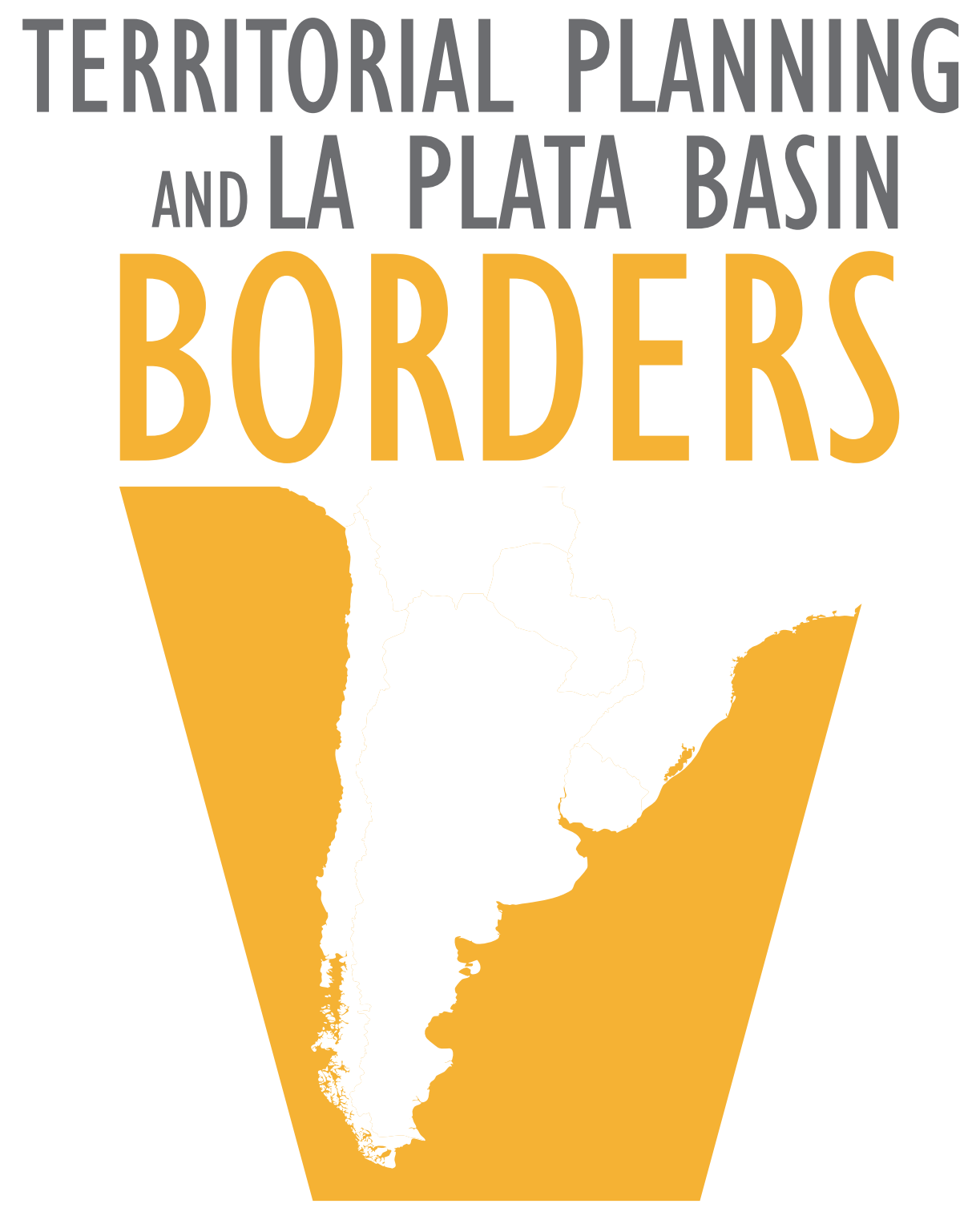

Antonio Paulo Cargnin

Aldomar Arnaldo Rückert

Bruno de Oliveira Lemos

(Eds.) 


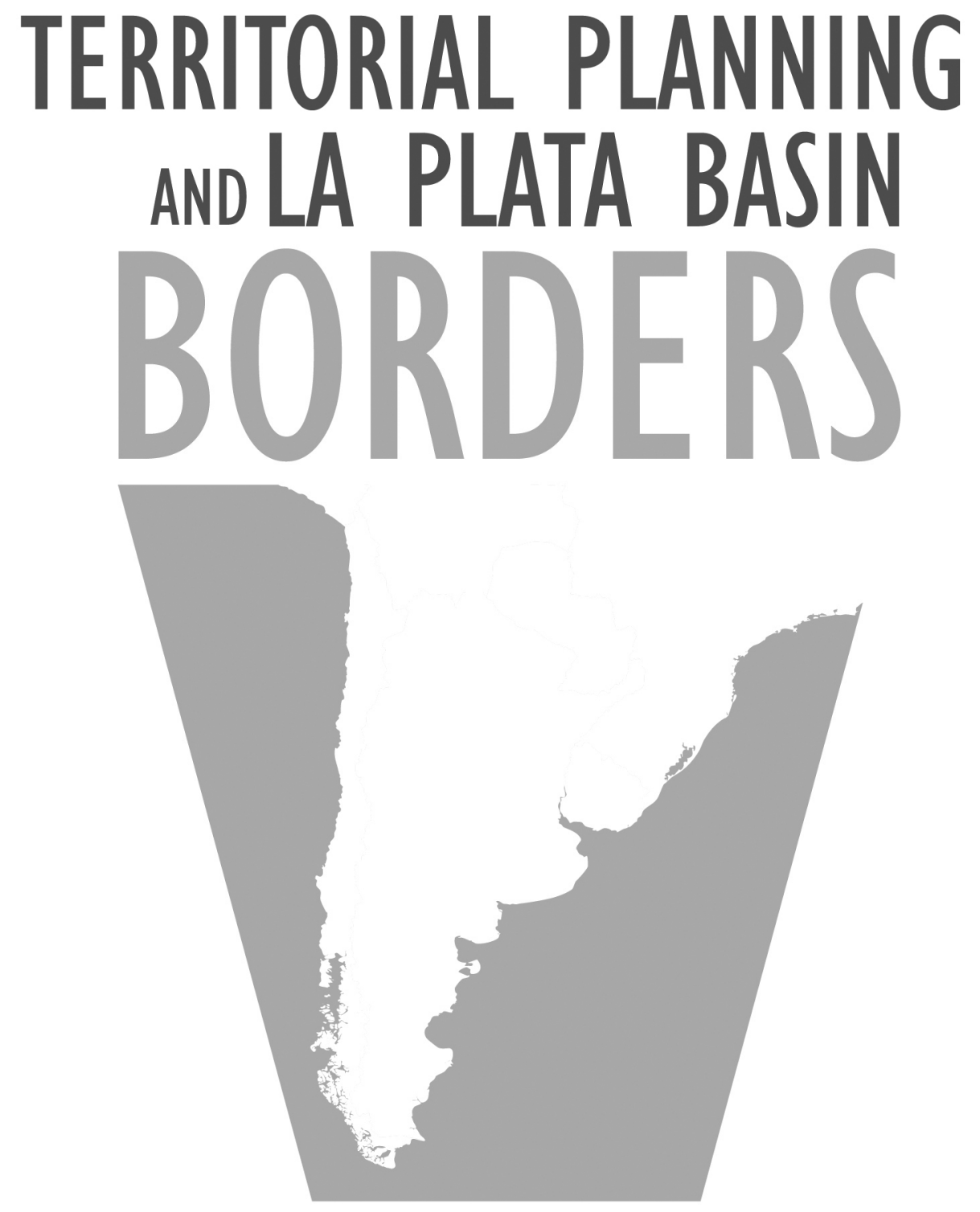

Antonio Paulo Cargnin

Aldomar Arnaldo Rückert Bruno de Oliveira Lemos

(Eds.) 


\section{Editors}

Antonio Paulo Cargnin

Aldomar Arnaldo Rückert

Bruno de Oliveira Lemos

\section{Editorial Board}

Carla Giane Soares da Cunha

Fernando Dreissig de Moraes

Irma Carina Macolmes

\section{Language Review}

Marlise Margô Henrich

\section{Layout}

Diego MeneghettI

Ronaldo Machado

\section{Cover Design}

Laurie Fofonka Cunha

\section{Institutional support}

Programa de Pós-Graduação em Geografia (POSGEA)

Instituto de Geociências (IGEO)

Universidade Federal do Rio Grande do Sul (UFRGS), Brazil

Secretaria de Planejamento, Governança e Gestão (SPGG)

Governo do Estado do Rio Grande do Sul, Brazil

\section{Dados Internacionais de Publicação}

Bibliotecária Regina de Carvalho Pereira CRB8/91772

\section{Letra}

www.editoraletra1.com.br letra1@editoraletra1.com (+5551) 33729222 Rua Lopo Gonçalves, 554 Cidade Baixa 90050-350 Porto Alegre, RS, Brazil CNPJ I 2.062.268/000I-37
T327 Territorial planning and La Plata Basin borders / Antonio Paulo Cargnin, Aldomar Arnaldo Rückert, Bruno de Oliveira Lemos (Eds.) . - Porto Alegre : Editora Letra1, 2018. 232p.

ISBN 978-85-63800-35-0 DOI 10.21826/9788563800350

1. Brasil - Fronteiras.2. La Plata - Fronteira. 3. Território. I. Cargnin, Antonio Paulo. II. Rückert, Aldomar Arnaldo. III Lemos, Bruno de Oliveira. III. Título.

CDD 320.12 


\section{Contents}

\section{Presentation}

Part | Territorial Dynamics and La Plata Basin Borders

Aspects of territorial and demographic dynamics in the southern border of Brazil

Ana Maria de Aveline Bertê, Antonio Paulo Cargnin,

Bruno de Oliveira Lemos \& Suzana Beatriz de Oliveira

Migratory dynamics and transbordering in La Plata Basin: an outlook at the transnational migration of Haitians and Senegaleses

Roberto Rodolfo Georg Uebel

La Plata region tripoints: state of the matter and descriptive comparison

Alejandro Benedetti

Territorial dynamics on the Brazilian Uruguayan cross-border: case study of the twin cities (Jaguaráo, BR-Rio Branco, UR) Heleniza Avila Campos \& Andressa Lopes Ribeiro

Part II Territorial policies applied to the borders of La Plata Basin

IIRSA and the role assigned to the La Plata Basin region in South American physical integration

Eduarda Figueiredo Scheibe

Energy transitions and regional integration in South America Silvina Carrizo \& Sébastien Velut

IIRSA-COSIPLAN and the Garabi-Panambi hydroelectric complex in the historical missionary territory

Ludmila Losada da Fonseca \& Aldomar Arnaldo Rückert

The imperfect synthesis between development and defense in border management in La Plata Basin

Flávia Carolina de Resende Fagundes 



\section{Presentation}

Pierre Monbeig, the great French geographer who participated in the founding of Universidade de São Paulo (USP) used to quote a saying he had often heard in the 1930s: "Brazil grows up at night, while the politicians are sleeping". This is still true today, as the dynamism of Brazilian society often allows it not to be blocked by the weakness or ineptness of public policies.

It seems that this is also the case more widely on the continent, as shown in the book coordinated by Antonio Paulo Cargnin, Aldomar Arnaldo Rückert and Bruno de Oliveira Lemos. They had intended to identify and analyze common territorial dynamics among the countries of the region, as well as recent transformations in the multi-scale territorial policies applied to the boundaries of La Plata Basin ${ }^{1}$. The cases presented in this book show precisely, in detail, the richness of current developments in these border regions, while national public policies, and even multilateral ones, are struggling to set up.

In general, borders present deficiencies due to their isolation from the central areas, and the boundaries of La Plata Basin present exactly these characteristics because, although they are located in the region of greater trade and population mobility of South America, they are often mere places of passage between the great centers, like São Paulo and Buenos Aires. In addition, the territorial policies applied to these borders usually presented a restrictive character to the development, due to the priority given to the policies of defense.

There has been no lack of political initiative for the integration of La Plata basin, but in general without much success, since they all have had ups and downs due to variation of the economic and political situations.

ALALC (1960) was the first one, but had mediocre results. The primary objective of the Treaty of La Plata Basin, in 1969, was its physical integration as a way of stimulating economic integration. The Financial Fund for the Development of the Río de la Plata Basin (FONPLATA) was set up in 1974, but the conjuncture was not favorable, due to divergences between the countries resulting from the installation of the hydroelectric plants of Corpus and Itaipú.

1 In their definition, the region including the basins of the Paraná, Paraguay and Uruguay rivers, to which they added São Paulo, due to the polarization it exerts on the region. 
The situation changed with the Treaty of Asuncion, signed on March 26, 1991, which created MERCOSUR/L, but in the period 1999-2002 it experienced a crisis, followed by a reversal in the years 2000, with the simultaneous election of leftwing governments in the region and a resumption of ECLAC's former concerns with productive integration. This led to the creation of the MERCOSUR/1 Fund for Structural Convergence and Institutional Strengthening (FOCEM) in 2005 and the MERCOSUR Productive Integration Program in 2008. However, the situation has changed again with the arrival of liberal-minded governments, especially in Brazil and Argentina.

The territorial analysis of policies carried out in the countries of $\mathrm{La}$ Plata Basin tends to express similar difficulties (starting with problems of compatibility of statistics). This framework makes it even more important to analyze the cross-border territorial dynamics and the different national policies concerning their borders, relating them to the various political contexts.

Fortunately, instead of concentrating (as most books on regional integration do) on the multiple episodes of treaty negotiations, this book analyzes what is really happening in the concerned areas. This is no doubt a reflection of the tendency of geographers to prefer to analyze real situations on the ground, rather than in meetings held in capitals, which are well known to include a great deal of rhetoric and role play.

Part I, Territorial Dynamics and La Plata Basin Borders, reviews a series of very specific topics.

Chapter 1 analyzes demographic dynamics in the southernmost State of Brazil, Rio Grande do Sul, and in neighboring countries, Uruguay and Argentina, where an emptying of the border regionsoccurs. The analysis shows that this dynamics is related to the lack of economic activity and of infrastructure, which have driven the population to the most dynamic and urbanized areas.

Cross-border migration is the object of chapter 2. Due to the saturation of models for the integration of immigrants in the Northern Hemisphere, La Plata Basin became an alternative to several new groups, among them, the Haitians and Senegalese, and the chapter analyses the dynamics of these two specific groups and their repercussions in the region.

Chapter 3 deals with the case of "tripoints" at the confluence of the Paraná and Iguaçu rivers, a specific geopolitical condition became a place name: the Triple Frontier. However, this is no more than one of the triangles formed in South America by the process of interstate delimitation, between 
the late nineteenth and early twentieth century. In total, there are thirteen of them, five of which involve the countries of the Plata region.

Chapter 4 is dedicated to the relationship between twin cities on the Brazilian-Uruguayan border, Jaguaráo (BR) and Rio Branco (UR). The territorial configuration of these cities reveals an integrated urban and dynamic culture to some extent influenced by the national policies of their particular countries.

Part II, Territorial policies applied to the borders of La Plata Basin, is also devoted to specific subjects, analyzed in a precise way.

Chapter 5 describes the role assigned by the IIRSA initiative to La Plata Basin region in South American physical integration, where a significant concentration of projects appears in its cross-border area, giving it a central role in the integration of the whole region.

Chapter 6, dealing with energy transitions and regional integration in South America, is less optimistic about integration in this field, mainly seen as a means to ensure the existing functioning by limited exchanges, rather than as a genuine transition instrument.

Chapter 7 is dedicated to a local conflict directly resulting from regional integration. IIRSA has included in its portfolio old projects, one of which is the construction of two dams on the Uruguay River, on the border between Brazil and Argentina. The implementation of the Garabi-Panambi Hydroelectric Complex will have an impact on the host cities; it reveals negative effects of the imposition of projects due to the absence of dialogue between municipalities and the State, as well as the lack of dialogue with the civil society.

Finally, chapter 8 rises to a wider perspective, the imperfect synthesis between development and defense in border management in La Plata Basin, still seen at local level, the Iguaçu cross-border region.

Although it is now well established that the guarantee of security necessarily passes through the development dimension, there is still a mismatch between development and security policies in the region, as shown by the case.

This book is therefore definitely the demonstration that, just as it is necessary to "think globally and act locally", even to think globally it is necessary to observe locally, as the local configurations very often reveal the stakes of regional, national and international scale conflicts.

Hervé Théry

Researcher of Centre National de la Recherche Scientifique Professor of Universidade de São Paulo (USP) 

Part I

\section{Territorial Dynamics and La Plata Basin Borders}





\title{
ASPECTS OF TERRITORIAL AND DEMOGRAPHIC DYNAMICS IN THE SOUTHERN BORDER OF BRAZIL
}

\author{
Ana Maria de Aveline Bertê, Antonio Paulo Cargnin, \\ Bruno de Oliveira Lemos \& Suzana Beatriz de Oliveira
}

\section{ABSTRACT}

This article aims at analyzing the behavior of territorial and demographic dynamics in the southernmost federation unit of Brazil, Rio Grande do Sul State, and in neighboring countries, Uruguay and Argentina. Based on previous studies conducted for the State, in which the intensification of the effects of demographic transition and the emptying of the border region were verified, this article sought to identify similarities in neighboring countries and discuss the possible causes of these dynamics. Data analysis showed that the sharp drop in population growth also strongly affects Uruguay, where the population tends to move to the southern coastal fringe, in the departments of Maldonado, Canelones and San Jose. In Argentina, this trend is less intense, except for Misiones that has attracted population. The analysis shows that, both in the border with Uruguay as in the greatest part of Argentina, this dynamics is related to the lack of economic activity and of infrastructure, which have driven the population to the most dynamic and urbanized areas.

KEYWORDS Population dynamics, demographic transition, regional development, Southern border of Brazil. 
The link between the emergence of the modern territorial State and the establishment of borders in Europe is recurrent in the bibliography on the subject, and is related to the need of the State delimiting the territory where its power is exercised. In this sense, it is important to affirm that the borders were built by the territory of the Nation-state. This concept of fixed borders appeared in the Modern Age, linked to the political needs of centralization of territorial power and to the development of a mercantile economy in Europe, as a counterpoint to the more diffuse and flexible medieval borders, a reflection of the decentralization of political power in the period (Badie, 1995). The formation of linear borders emerges with the modern State from the fourteenth and fifteenth centuries on, when the link between the State and the citizens becomes the territory, which is the subject of sovereignty (Raffestin, 1986).

In approaching the nation-state, Foucher (2009, p. 22), in one of his works, addresses an institutional concept of border:

Borders are territorial discontinuities, with the function of political marking. In this sense, they are institutions established by political decisions, designed or imposed, and administered by legal texts: the laws of a sovereign State within them, public international law as a common law of coexistence of States even when they are dissolved, because territorial treaties are the only ones by which the succession of State is automatic.

In another definition, Foucher (1991, p. 38) defines borders, in a broader sense, as elementary spatial structures, in a linear way, with a function of geopolitical discontinuity and marking, of reference on the registers of the real, the symbolic and the imaginary. The real refers to the exercise of sovereignty in its own modalities; the symbolic refers to the sense of belonging to a political community; and the imaginary refers to the relation with the other, with oneself, with its own history and with the founding myths.

In the case of the southern border of Brazil, an effective occupation of this territory by the Europeans occurred late, linked to the disputes between Spain and Portugal for Colonia de Sacramento in the eighteenth century. However, attempts to delimit this border only took place in the nineteenth century, with the 
independence of Brazil ${ }^{1}$, Argentina and Uruguay. In fact, the limits with Argentina were only consolidated in 1898, and with Uruguay, in the year 1909. Rio Grande do Sul State (RS) is located in the southern portion of Brazil, including the country's border with Argentina and Uruguay, as shown in Figure 1.

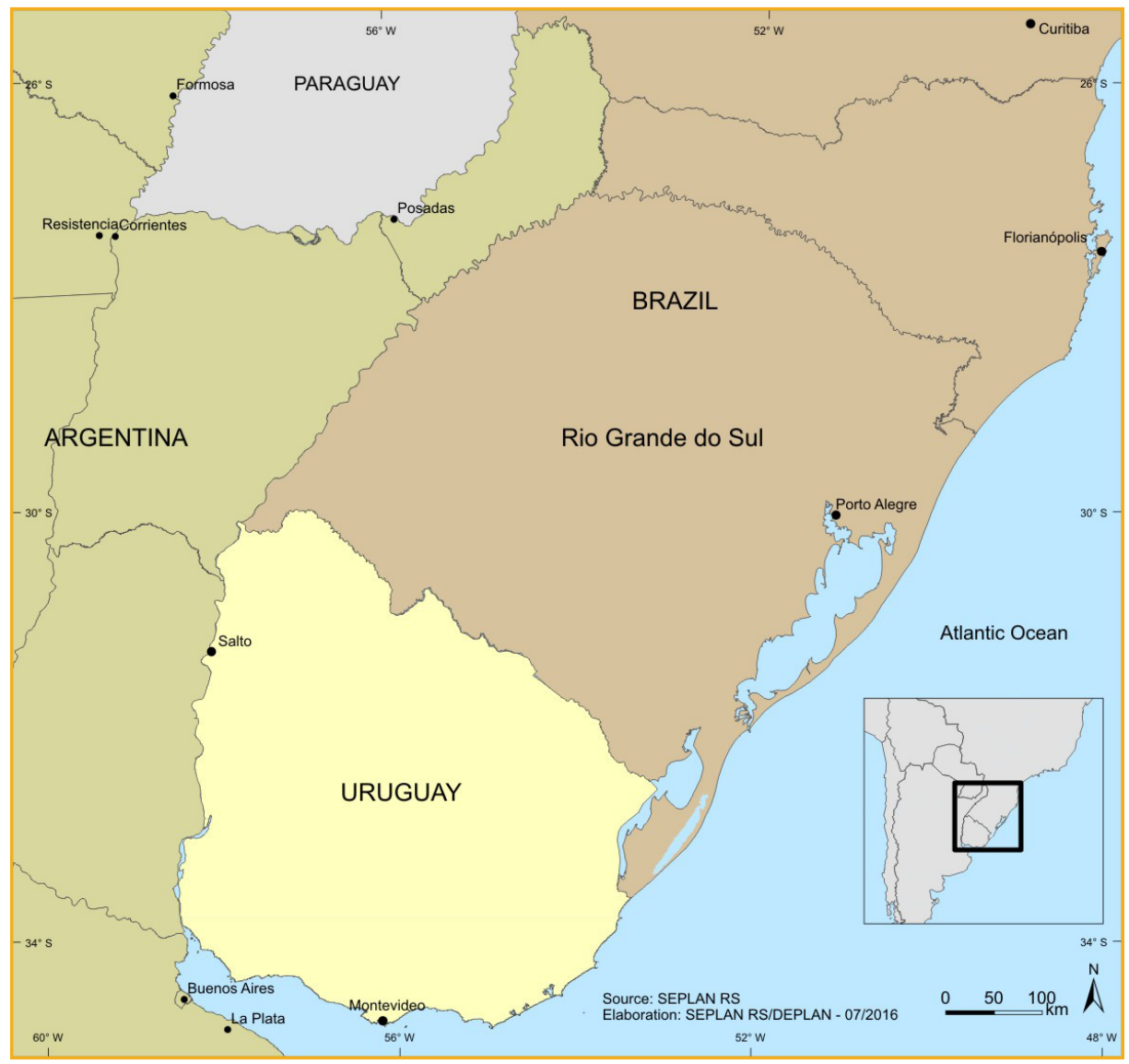

Figure I. Map of the limits of Brazil with Argentina and Uruguay.

The differences in the regions of border with Uruguay and Argentina are in great part due to the physical characteristics of the area, as well as to the colonization history. In the border between Brazil and Uruguay, the integration characteristics of the dry land border and the joint socioeconomic development contributed for a

1 Magnoli (1997, p. 242) states that the predominant period of delimitation of the Brazilian borders is that of the Empire, contrary to what the "myth" of the antiquity of Brazilian borders defends. 
similar productive structure on both sides of the border. The non-establishment of the borders of the Uruguayan territory soon after the independence of that country is related to political identities still in formation, because in this period there was a common identity, indistinct from the one of Brazil. According to Caetano (2011, p. 171), referring to the period of Uruguayan independence:

Proliferaban por entonces, como ha sido estudiado largamente, una multiplicidad de identidades que iban desde distintas formas que referían a las nociones de lo provincial (“oriental”, "porteño", "cordobés"), lo regional ("argentinos", entendidos por entonces como rioplatenses) y aún lo continental ("americanos" o la persistente idea de "españoles americanos"). Los grandes conflictos y procesos sociales se dirimían en el territorio de la región. No existían fronteras: ni jurídicas (no los preveía por ejemplo la primera Constitución de 1830), ni políticas (los bandos argentinos e orientales, unitarios y federales y blancos y colorados, se asociaban permanentemente entre sí, así como también con los grupos de la conflictiva zona sur del Imperio del Brasil), ni económicas (el gran negocio de la región era el llamado comercio de tránsito, con los grandes ríos como hidrovías disponibles y disputadas) ni tampoco sociodemográficas (las incipientes configuraciones sociales y las primeras cadenas inmigratorias se asociaban a poblaciones que se desplegaban y radicaban con muy vagos sentimientos de limites). ${ }^{2}$

This predominance of cross-border characteristics between Brazil and Uruguay prevailed over a long period, until the definitive demarcation of the border in the 1920s, resulting in a joint socioeconomic development in the region. In studying the

\footnotetext{
2 At that time, as has been studied at length, a multiplicity of identities proliferated, ranging from different forms that referred to the notions of provincial ("oriental", "porteño", "cordobés"), regional ("Argentines", then considered as Rioplatenses) and even continental ("Americans" or the persistent idea of "American Spaniards"). The great conflicts and social processes were settled in the territory of the region. There were no frontiers: neither juridical (not foreseen in the first Constitution of 1830), nor political (the groups of Argentinean and Eastern, unitarian and federal, and blancos and colorados were permanently associated with each other, as well as with the groups of the conflict southern zone of the Empire of Brazil), nor economic (the great business of the region was the so-called transit trade, using the big rivers as available and disputed waterways) nor even sociodemographic (the incipient social configurations and the first immigration chains were associated with populations that were deployed and settled with very vague notions of limits.).
} 
border scenarios of Peru, Cuisinier-Raynal (2001) describes five unique situations ${ }^{3}$, including the concept of Synapse that seems to fit the border between Brazil and Uruguay, with an intense exchange rate between the populations of both countries, and strong support from contiguous states.

Broadly speaking, it may be stated that, on the Brazilian side, rice crops in the flood plains of rivers and cattle and sheep breeding predominate. On the Uruguayan side, besides cattle and sheep breeding, forestry also stands out. The economic structure of the region is based on agriculture in medium and large estates, which does not favor the transfer of resources from trade of agricultural products to industry. Besides, there were no significant changes in the productive sector, with industry remaining linked to a traditional base and slow incorporation of technology.

In the border between Brazil and Argentina, the difficulties of interaction caused by the barrier represented by Uruguay River hinder a greater socioeconomic relationship. Based on the Cuisinier-Raynal typology (2001), it may be said that this border has some characteristics of Margins (Marges), with no major private contacts between border populations and State investments in infrastructure and border cooperation, and Buffer zones (Marche), especially in the northwest of Rio Grande do Sul, where cross-border relationships are sporadic and made by small roads, and also where the States have created natural parks, protected areas or reserved zones.

The only two road links between both countries occur through the cities of São Borja-Santo Tomé and Uruguaiana-Paso de los Libres, since there are no bridges in the northwest of Rio Grande do Sul State. In the Brazilian side of the border, rice crops and cattle and sheep breeding predominate at south; and soybean, corn, wheat and cassava crops, as well as cattle and swine breeding predominate at north. Also, the presence of industry of agricultural machinery and tools stands out. On the Argentine side, besides cattle breeding, rice, soy, forestry and yerba-mate stand out. On both sides of the northern Brazilian-Argentine border, the tourism related to natural and historical characteristics of the regionalso predominates, linked to the Jesuit Missions, established in Rio Grande do Sul from 1626 on.

3 Namely: Margins (Marges); Buffer-zones (Marches), Fronts (Fronts), Synapses (Synapses) and Capillaries (Capillaires). 
Concerning demography, the recent prospective study, RS 2030: Agenda de Desenvolvimento Territorial (RS 2030: Territorial Development Agenda; Rio Grande do Sul, 2014), has made a comprehensive reflection about the current trend of demographic emptying of the international border region of Rio Grande do Sul. The study pointed out several very serious repercussions on the economic and social dynamics of the region and the State as a whole.

This article envisages to identify similarities in the processes that occurred in neighboring countries and to discuss the possible causes of these dynamics. Therefore, it presents a comparative analysis of two interrelated processes that may worsen the socioeconomic situation of these regions: the aging of the border population combined with the loss of labor for regions with greater socioeconomic development.

Based on these aspects, this article also seeks to point out, with basis on previous studies (Rio Grande do Sul, 2012; Bertê et al, 2016), some possible reasons why this movement of population loss has become so pronounced in recent years. The crossborder and multi-scalar analysis allowed identifying the position of Rio Grande do Sul concerning the Demographic Transition ${ }^{4}$ in relation to other territorial units, as well as factors in common with neighboring countries that can stimulate the exit of population from the border regions.

As methodological procedures, population data provided by the governments of the three countries were used, and organized according to the age groups from 0 to 14 , from 15 to 64 and over 65 years. In addition, the annual population growth rates of the inter-census periods were compared in order to identify possible population losses. The methodology covered the compared areas defined by Rückert, Carneiro Filho and Uebel (2015) for MERCOSUR. Finally, an analysis of economic factors and transport infrastructure that may be contributing to this regional scenario of population losses is carried out.

\footnotetext{
4 Demographic transition is a dynamic phenomenon that affects populations over time, in which, at first, there is an increase in population growth rates (a demographic explosion), but with the drop in the birth rate, population growth rate decreases over time, tending towards stability or, even, reduction.
} 


\section{DEMOGRAPHIC DYNAMICS OF RIO GRANDE DO SUL STATE AND ITS SIMILARITIES WITH URUGUAY AND ARGENTINA}

Recent studies, published in the series RS 2030: Agenda de Desenvolvimento Territorial, elaborated using data from population censuses of IBGE - Instituto Brasileiro de Geografia e Estatística (Brazilian Institute of Geography and Statistics), revealed some demographic tendencies that have been conforming in Rio Grande do Sul State. These movements, which had already been detected in previous researches and censuses, became even more evident from the Census 2010 on (Jardim; Barcellos, 2011; Cargnin et al., 2014).

One of the first tendencies observed, which also started in the 1970s, was the significant increase in urban population rates. It must be taken into consideration that urbanization is a process that takes place in global scale. In Rio Grande do Sul State, the movement meant an important population shift to RMPA Regiáo Metropolitana de Porto Alegre (Porto Alegre Metropolitan Region). It also represented a significant growth of cities near traditional urban centers, forming the current urban network. Figure 2 shows the demographic density of the municipalities of Rio Grande do Sul in 2010, which has a large population concentration in the State northeast.

Another more recent trend shows a relationship with the phenomenon known as demographic transition. The reduction of the population growth rate and the increase of life expectancy tend to cause an inversion in the traditional pattern of the demographic pyramid, with population increase in older age groups.

The population of Rio Grande do Sul, that reached the 10.7 million mark in 2010, representing 5.6\% of the Brazilian population, with a declining trend in this participation, has been suffering the impacts of this transition. After a high population growth in the 1950 s, when growth rates reached $2.59 \%$, the pace decreased progressively, reaching the 1980s with an average annual growth rate around $1.55 \%$. In the 1990 s, these values were reduced to $1.48 \%$ and, in 2000 , they reached $1.21 \%$. Data of the last Census indicate a further decline in this growth pace, reaching a rate of $0.49 \%$ p.a., lower than the one of $1.17 \%$ of the Country, placing Rio Grande do Sul as the Brazilian state whose population had the lowest growth in the decade. 


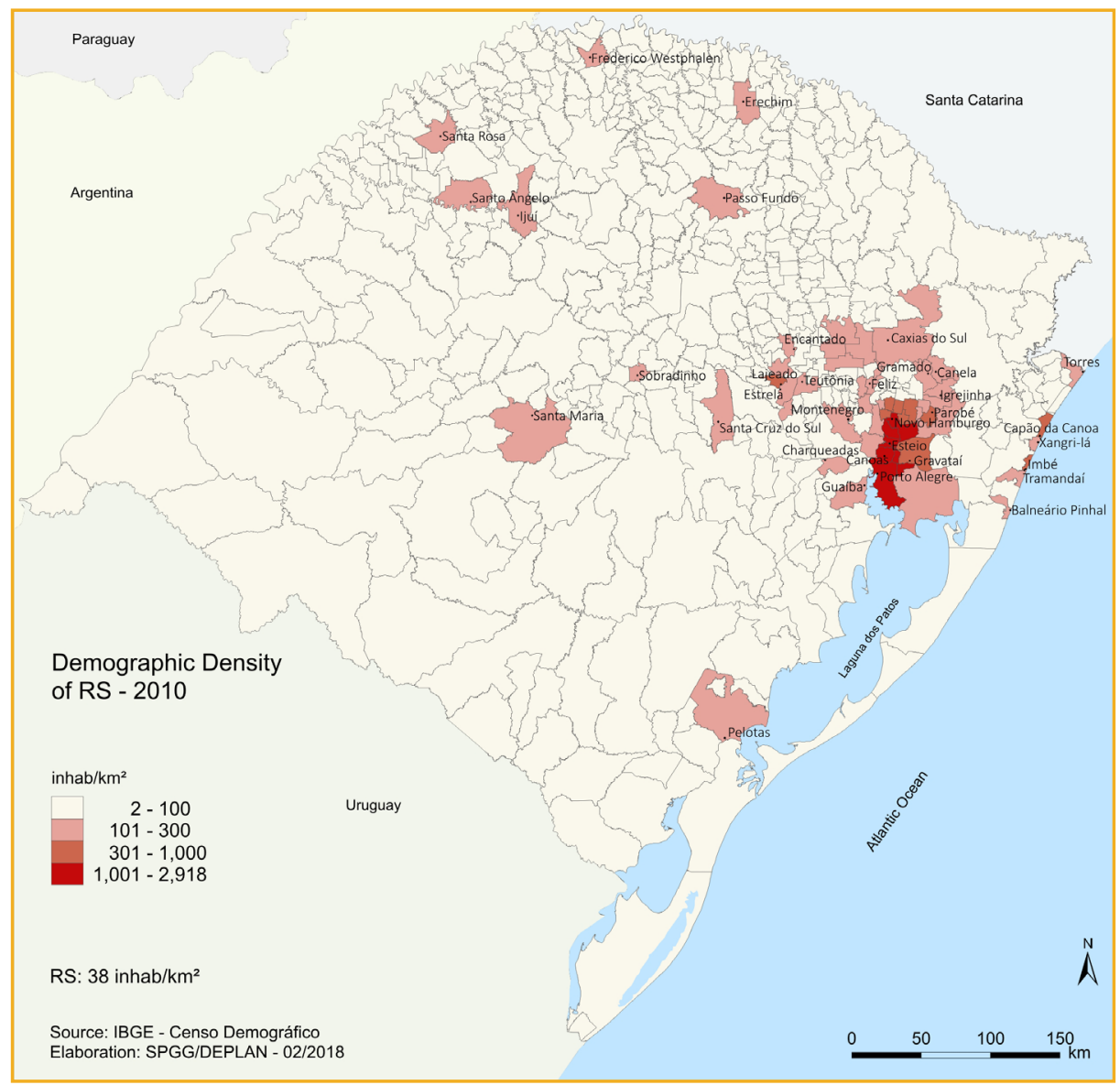

Figure 2. Demographic Density of RS -2010 .

The major factor in this process is the decline in the fertility rate presented by the State. The average number of children per woman in 2010 was 1.8, a figure which is already below the population replacement rate ${ }^{5}$ that is 2 children.

The decline in the fertility rate, as well as in mortality, besides the increase in life expectancy ${ }^{6}$ directly affects the population age structure. In the case of life

5 Population replacement rate is the average number of children that women between 15 and 49 years of age need to have in order that the population remains constant.

6 Life expectancy at birth is the average number of years that a group of individuals born at the same year are expected to live, if the mortality rates identified in the year of observation are steady since their birth. 
expectancy, Rio Grande do Sul, for many years, differs among Brazilian states, with one of the highest life expectations of the Country. The analysis of the period 19702010 indicates that there was an increase of more than eight years in the state life expectancy, from 67.8 to 75.9 years in the last three decades, as may be observed in Figure 3.

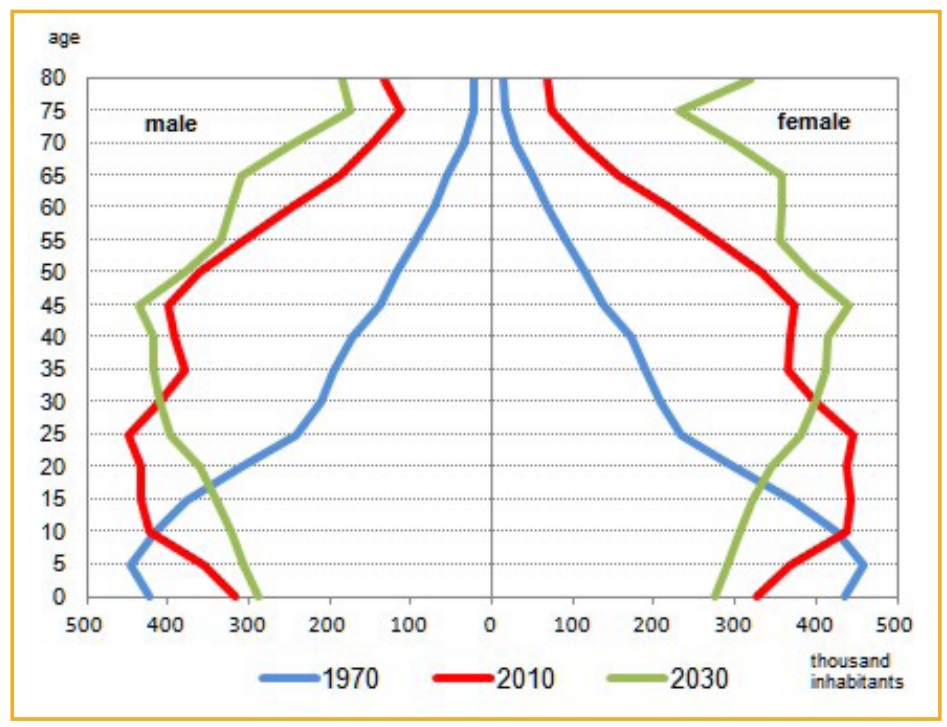

Figure 3. Population distribution by age and gender, RS - 1970, 2010 and 2030.

Source: Rio Grande do Sul State Government, 2014.

The results of the projections made by FEE - Fundação de Economia e Estatística (Economics and Statistics Foundation) until the year 2050 must be added to these data, which reveal some aspects that demand attention, shown in Figure 4. A first aspect refers to the fact that Rio Grande do Sul will reach a maximum contingent of 11 million inhabitants in 2025 and, from then on, will undergo a gradual reduction of its absolute population, totaling 9.7 million in the year 2050. Rio Grande do Sul should be one of the first states to achieve a negative growth rate in Brazil, starting a gradual process of stabilization and reduction of its population.

There is a great disparity when this projection is analyzed by age. The contingent of population between 0 and 14 years, which has already shown a reduction between the years 2000 and 2010, should continue to fall. The number of people aged between 15 and 64 years will continue to increase and reach a maximum contingent 


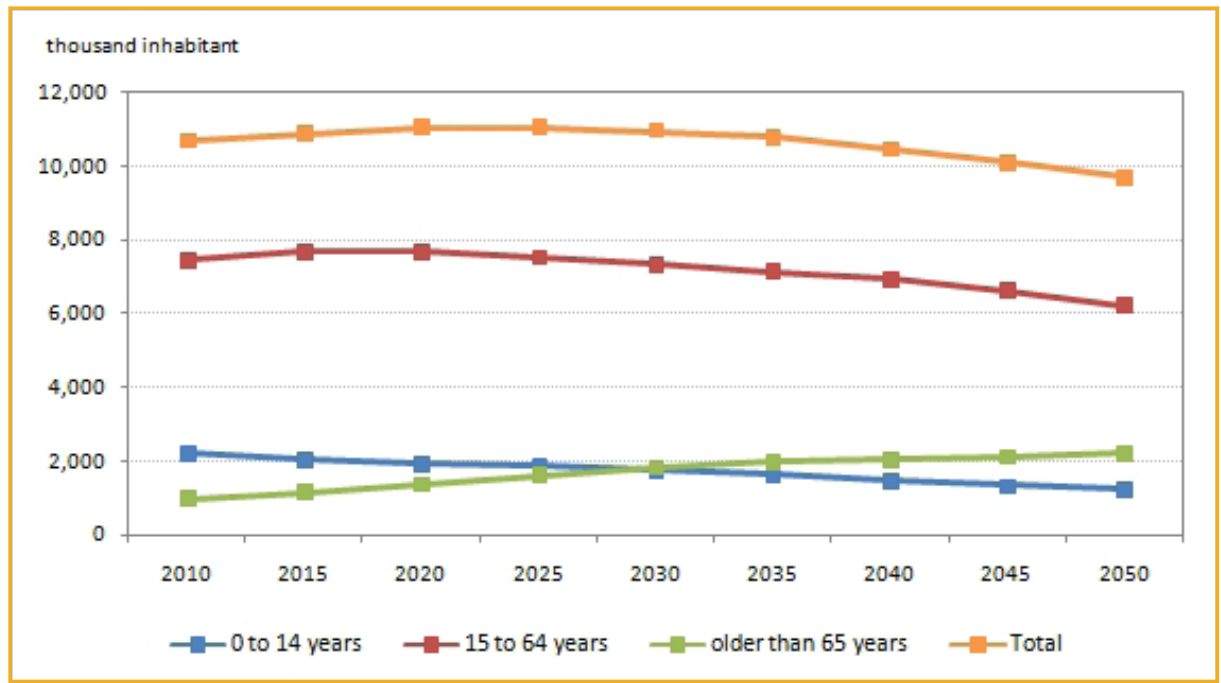

Figure 4. Population of RS, by age group 2015 to 2050 (in thousand inhabitants).

Source: Rio Grande do Sul State Government, 2014.

between 2015 and 2020 and, from then on, it will begin a process of reduction. Finally, the population older than 65 will continue to increase in next decades. This kind of population growth behavior indicates that the State is undergoing a demographic transition, in which the weight of the population considered inactive (those from 0 to 14 years plus those older than 65 years) divided by the working population (from 14 to 65 years) is still smaller.

If this projection for the next decades is confirmed, Rio Grande do Sul is in the height of this proportion since, from the next decade on, the relationship between inactive and active would begin to grow. Therefore, the State is experiencing the so-called Demographic Bonus, i.e., a period in which the active population is proportionally more numerous than the inactive one. Such condition indicates an advantage for development, since the most numerous active population creates better conditions for production, savings and investment. However, it is important to consider that an ageing population in coming decades involves several challenges to society and the government, mainly in issues related to health and welfare. 
Extending this analysis to neighboring countries, based on data from the Censuses of Brazil $(2010)^{7}$, Argentina $^{8}$ (2010) and Uruguay9 (2011), it is possible to identify how the demographic transition is manifested in the surrounding administrative units, causing problems in the border area. For comparison purposes, the methodology used by Rückert, Carneiro Filho and Uebel (2015) was used. Based on the Nomenclature of Territorial Units for Statistics of the European Unit (NUTS), they defined comparable areas for MERCOSUR countries, according to the following levels.

Table I

Levels of space division and number of units per country

\begin{tabular}{lcc}
\hline \multicolumn{1}{c}{ Country } & Level II & Level III \\
\hline Argentina & Provinces (24) & Departments or Partidos (501) \\
Brazil & States (27) & Geographic Micro-regions (558) \\
Paraguay & East and West (2) & Departments (18) \\
Uruguay & Country & Departments (19) \\
Bolivia & Departments (9) & Provinces (112) \\
Chile & Regions (13) & Provinces (51) \\
\hline
\end{tabular}

Source: Rückert, Pereira e Uebel, 2015.

In this text, only the administrative units of Brazil, Argentina and Uruguay were assessed in order to verify the status of Rio Grande do Sul State and its border region in relation to the neighboring territories. It is also important to state that, for Level III of the Brazilian territory, specifically in the case of Rio Grande do Sul, the scale of COREDEs ${ }^{10}$ will be used, since it is a reference of regionalization for governmental planning of the State.

7 Data from IBGE - Instituto Brasileiro de Geografia e Estatística (Brazilian Institute of Geography and Statistics).

8 Data from INDEC - Instituto Nacional de Estadística y Censos.

9 Data from INE - Instituto Nacional de Estadística.

10 COREDEs - Conselhos Regionais de Desenvolvimento (Regional Councils of Development) were established by the State Government through State Law 10,283, dated Oct 17, 1994. They are a permanent and autonomous forum for the discussion and decision of policies and actions that envisage regional development. At present the State has 28 COREDEs. 
Therefore, the levels of analysis for Argentina, Brazil and Uruguay were, respectively: provinces, states and country, for Level II; and Departments or Partidos, COREDEs and Departments, for Level III, as may be observed in Table II ${ }^{11}$.

Table 2

Levels of space division and number of units per country

\begin{tabular}{lcc}
\hline \multicolumn{1}{c}{ Country } & Level II & Level III \\
\hline Argentina & Provinces (24) & Departments or Partidos (501) \\
Brazil & States (27) & COREDEs (28) \\
Uruguay & Country & Department (19) \\
\hline
\end{tabular}

Source: Adapted from Rückert, Pereira e Uebel, 2015.

Concerning the population in working age, Rio Grande do Sul State is located in southern Brazil which, along with the central region, has the highest percentage of population in this age group. The same occurs comparatively with the three countries studied. In 2010, the State had $69.85 \%$ of its population in the ages between 15 and 64 years, only being surpassed by the states of Rio de Janeiro (69.90\%), São Paulo (70.69\%), Santa Catarina (71.26\%) and the Federal District (71.36). The national averages for Brazil (2010), Argentina (2010) and Uruguay (2011) are, respectively, 68.54\%, 64.25\% and 64.10\%. Therefore, the presence of a Demographic Bonus period in Rio Grande do Sul is emphasized. Figure 5 shows the percentage of population between 15 and 64 years for Level II.

The analysis of data for comparative areas in Level III disaggregates this information, reinforcing the idea that Rio Grande do Sul would be close to its peak of effectiveness of the Demographic Bonus. It may noticed that the highest percentages of population between 15 and 64 years are located in the northeast of the State and in some industrial regions in the central-north, which have received population in working age from the border regions of RS. In Argentina and Uruguay, the percentages of population for this age group are much lower than those found in Rio Grande do Sul State. Figure 6 shows the percentage of population from 15 to 64 years for Level III based on the censuses of the three countries.

11 Level I was not represented by country because Uruguay was already classified in Level II, due to the disproportion of the population of that country in relation to Argentina and Brazil. 


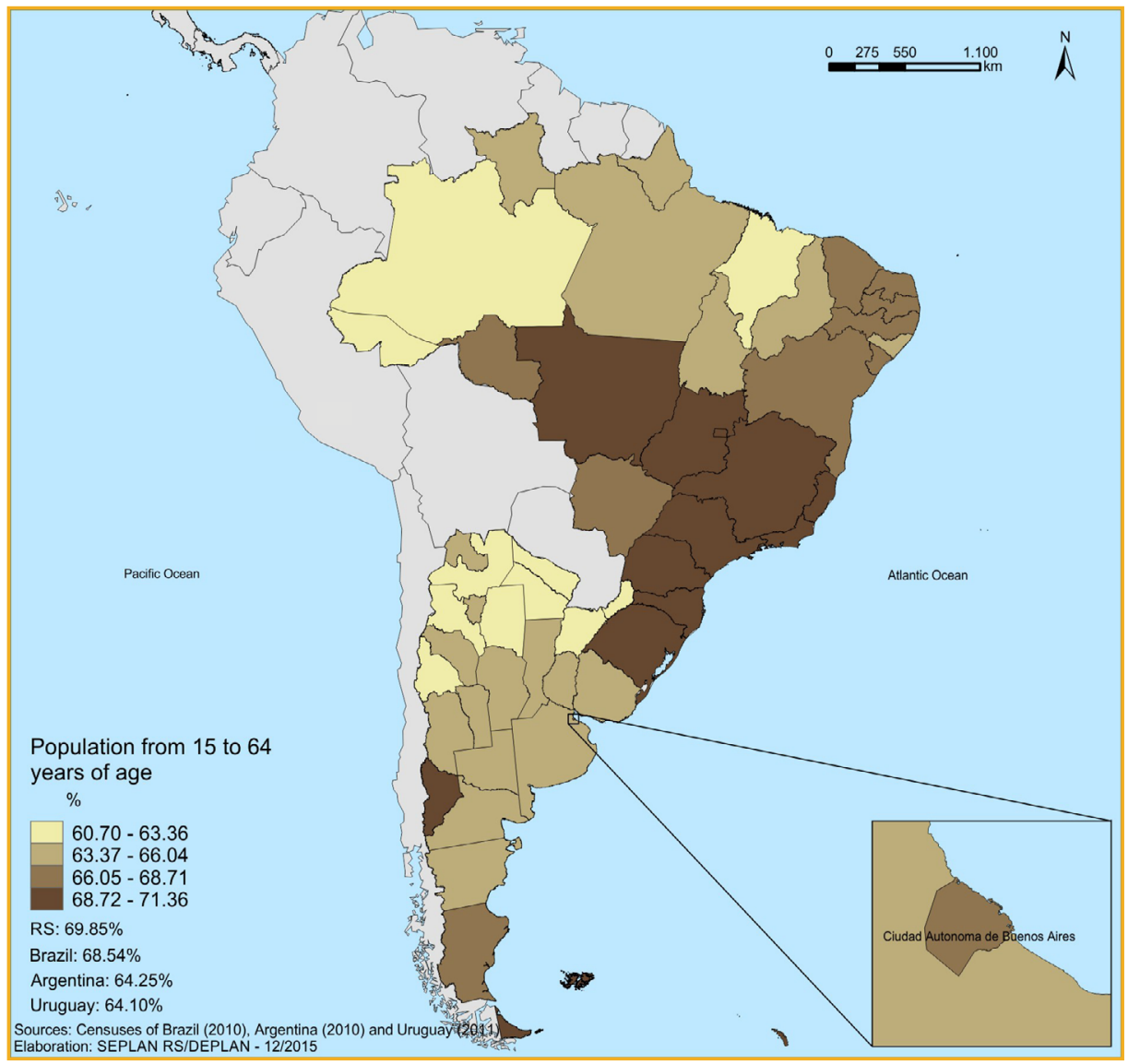

Figure 5. Percentage of population from 15 to 64 years of age in Brazilian states, Argentine provinces and Uruguay - Comparable areas Level II.

Regarding the population in advanced age, older than 65 years of age, it is observed that, for comparable areas Level II, Ciudad Autónoma de Buenos Aires had the highest concentration, with $16.40 \%$, followed by Uruguay, with $14.10 \%$. High percentages are also observed in the Argentine provinces of Santa Fé (11.80\%), Córdoba (11.20\%) and La Pampa (11.2\%), besides others from central-eastern region of Argentina, as shown in Figure 7.

Rio Grande do Sul presented a percentage of $9.30 \%$ elderly, above the Brazilian average $(7.38 \%)$ and the highest of the Country, although below the averages of Argentina and Uruguay. However, in coming years, the State tends to have averages 


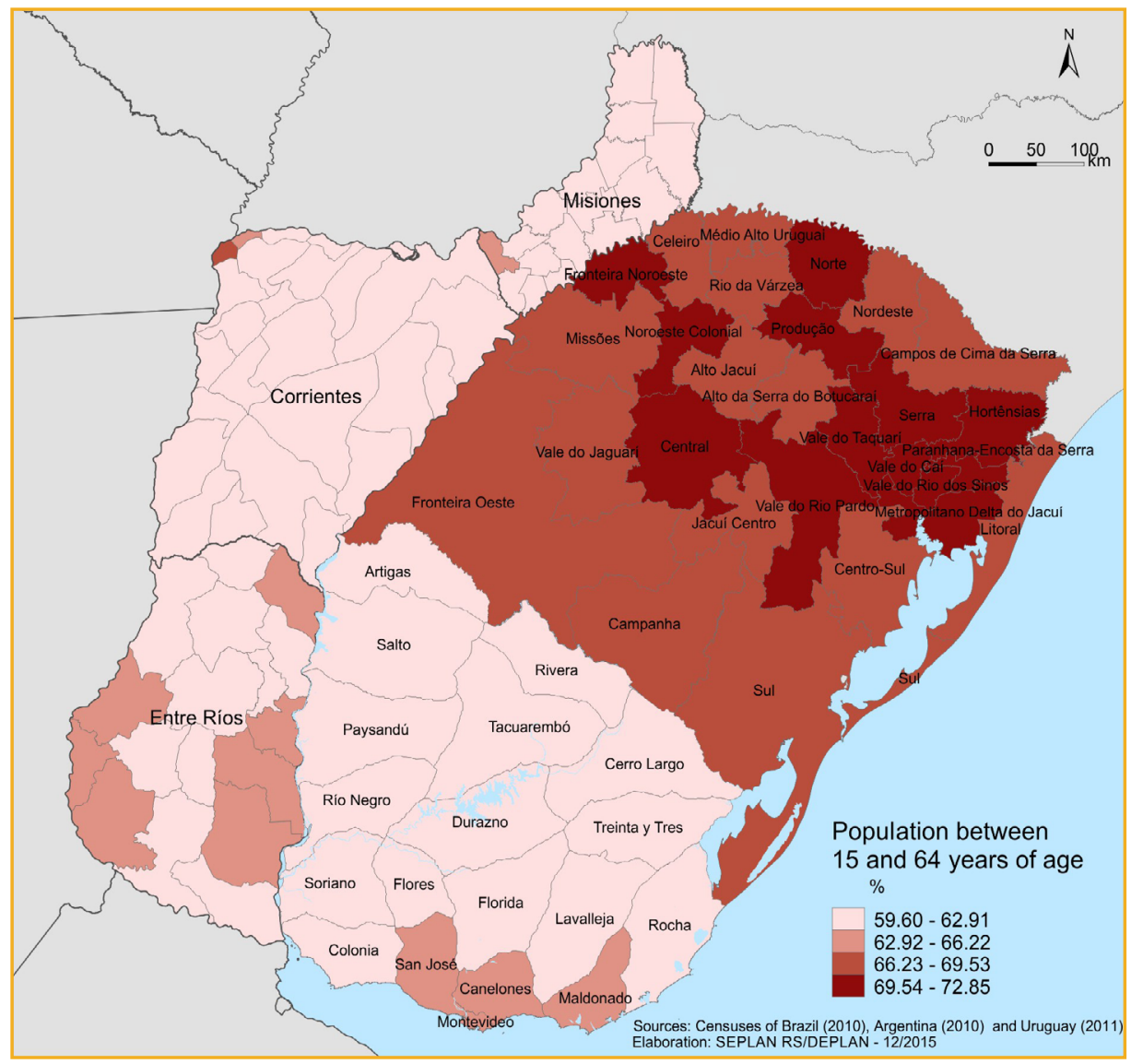

Figure 6. Percentage of population between 15 and 64 years in State's COREDEs and Argentine and Uruguayan departments - Comparable areas Level III.

increasingly similar to those of these countries, due to the current high percentage of population in working age, and a more intense ageing process of the population when compared to the other states of the Federation.

Figure 8 shows the concentration of elderly population for comparable areas of Level III, with emphasis for the departments of southern Uruguay, especially Lavalleja (16.70\%) and Colonia (16\%). COREDEs with the highest percentages of elderly population in Rio Grande do Sul presented recent population losses, mainly of population in working age, particularly Centro (12.20\% of the elderly), Vale do Jaguari (11.83\%) and Fronteira Noroeste (11.62\%), located on the Brazilian Borderland. 


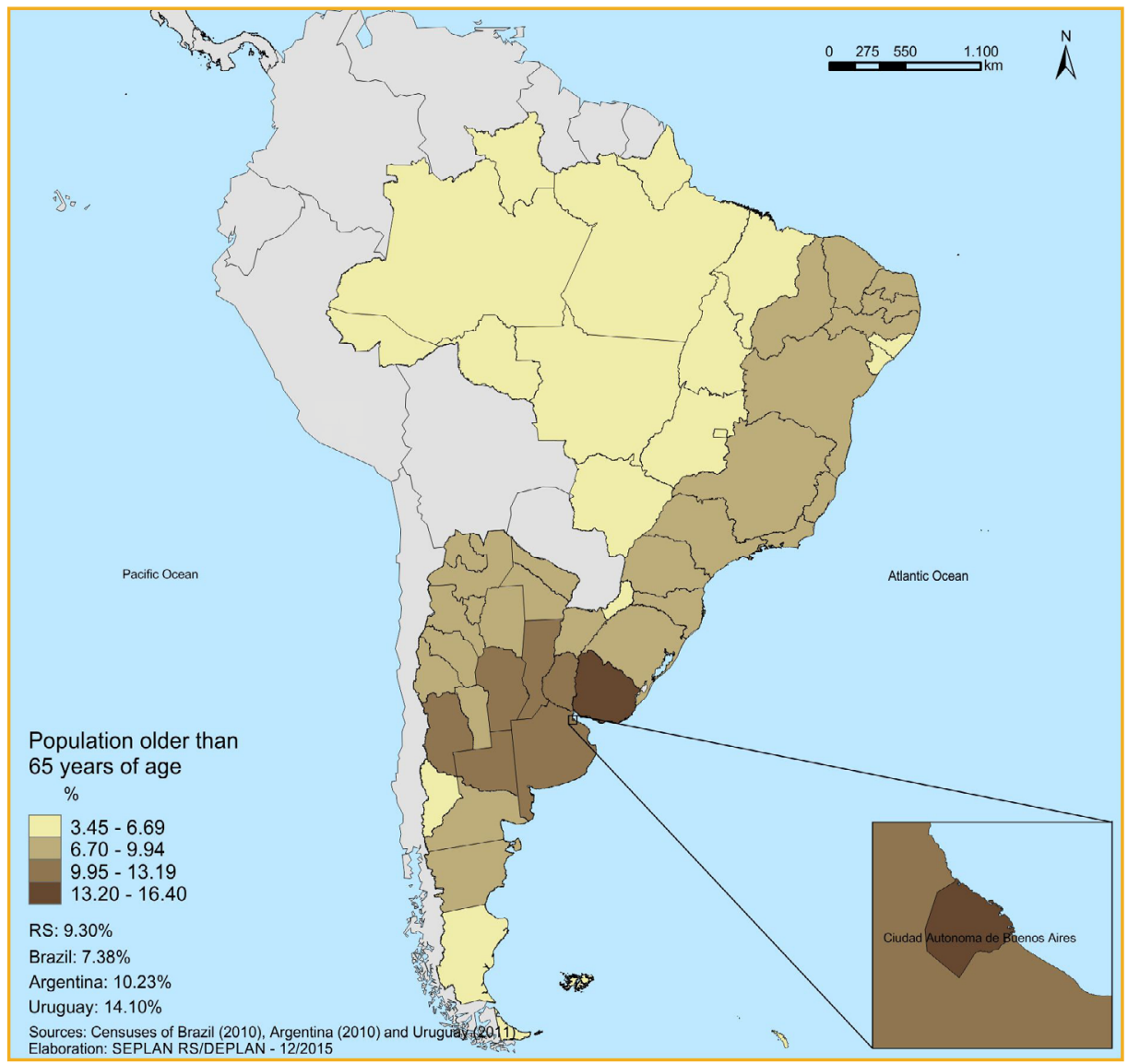

Figure 7. Percentage of population older than 65 years in Brazilian states, Argentine provinces and in Uruguay - Comparable areas Level II.

In general, it is noted a population ageing trend in the border area analyzed, and in Uruguay, where the demographic transition process is already consolidated, the percentages are higher. Most of the Argentine departments, as well as of the Regional Councils of Development tend to follow the same trend.

Concerning the younger age group, from 0 to 14 years, in total population, the north of Brazil and of Argentina concentrate the highest percentages. In Brazil, the states of Acre (33.70\%), Amazonas (33.18\%), Amapá (33.14\%) and Roraima $(33.05 \%)$ stand out. In Argentina, the highest percentages are in the provinces of Misiones (32.50\%) and Santiago del Estero (31.60\%). Ciudad Autónoma de Buenos Aires had the lowest percentage, with 16.30\%, as shown in Figure 9. 


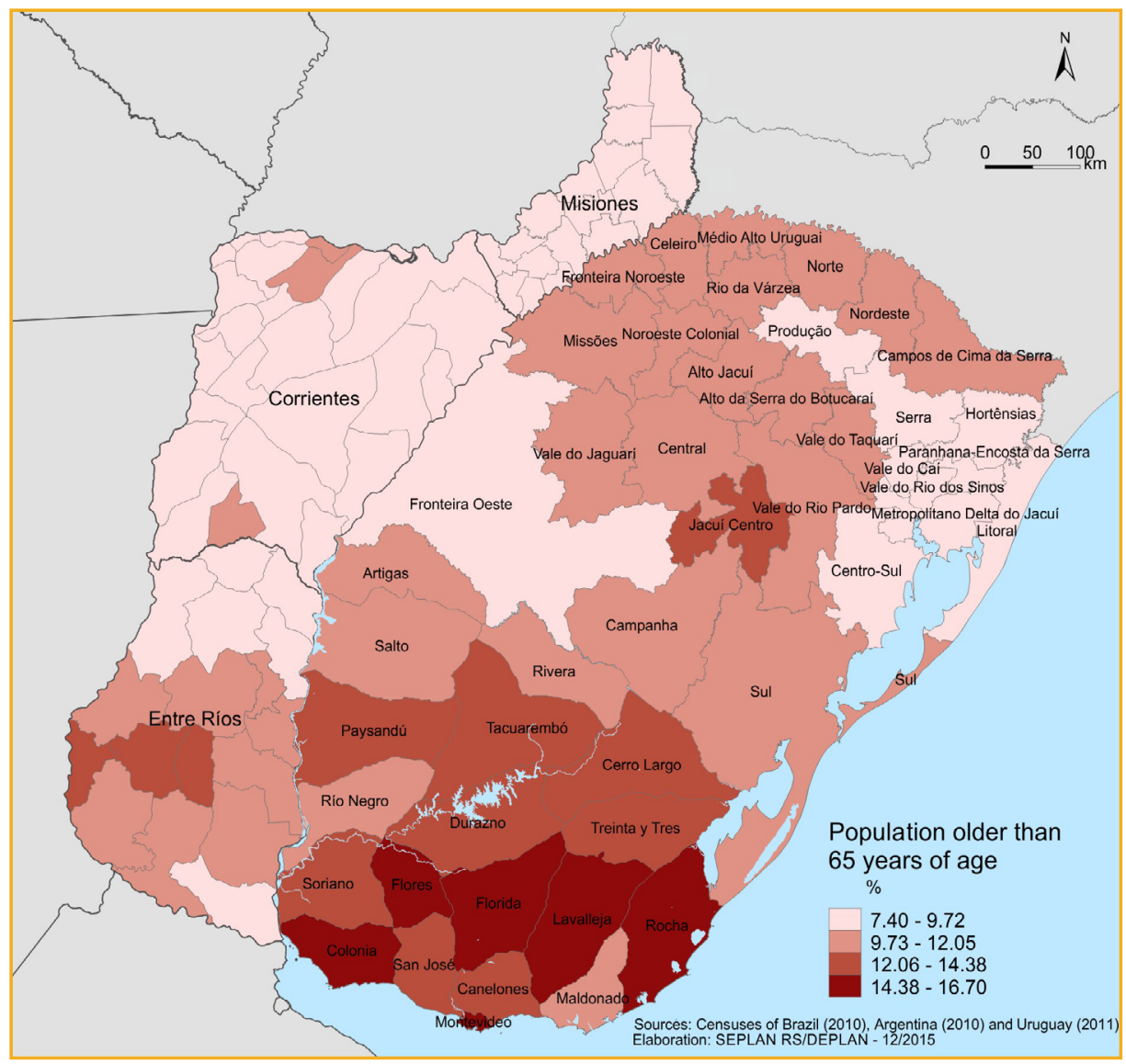

Figure 8. Percentage of population older than 65 years in COREDEs and Argentine and Uruguayan departments - Comparable areas Level III.

Data from Census 2010 showed that Rio Grande do Sul had a share of only $20.85 \%$ young people in its population, a percentage that is below Brazilian, Argentine and Uruguayan averages. This low participation of children indicates that RS will face significant difficulties in replacing its current working age population

The limit with Argentina represents an important rupture in demographic structure, since San Pedro (40.10\%), General Manuel Belgrano (38.5\%) and Guarani (37.6\%) departments, in Misiones province, have high percentages of population below 15 years of age. The same applies to the whole province of Corrientes, as shown in Figure 10. 


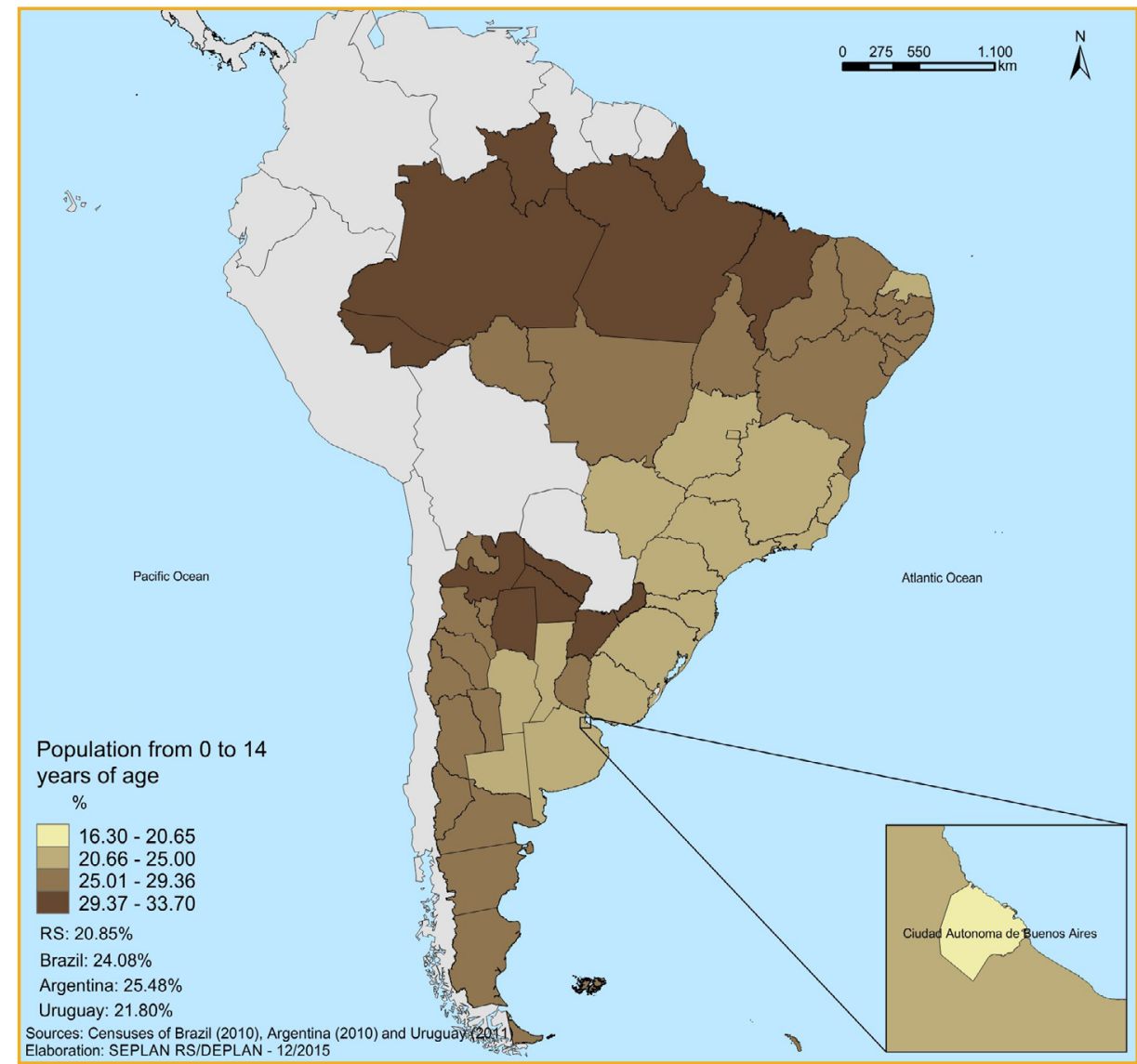

Figure 9. Percentage of population from 0 to 14 years of age in Brazilian states, Argentine provinces and Uruguay - Comparable areas Level II.

For the analysis of average annual population growth rates, different periods were considered for the three countries, due to the limitations imposed by the temporality of the censuses. For Brazil, IBGE data for the period 2000-2010 were used. For Argentina, INDEC data were extracted for the period 2001-2010. As for Uruguay, INE data for the period 2004-2011 were used. The results are shown in Figure 11 .

According to Figure 11, considering an analysis for Level II, Rio Grande do Sul, Uruguay and Ciudad Autónoma de Buenos Aires constitute a core of low population growth in the area. It is also worth noticing that the highest population 


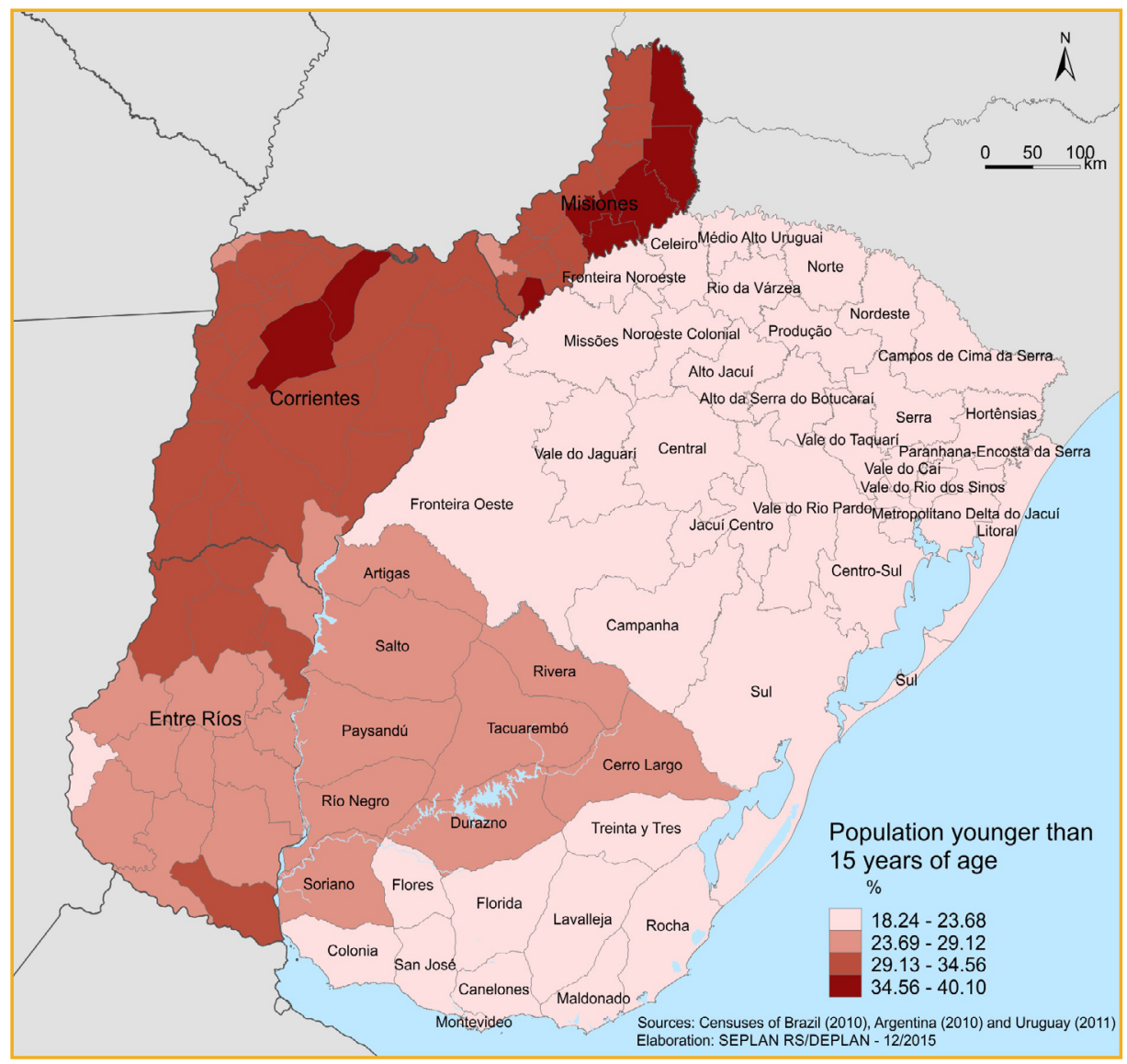

Figure 10. Percentage of population from 0 to 14 years of age in COREDEs and Argentine and Uruguayan departments - Comparable areas Level III.

growth rates for the three countries occurred in peripheral regions, in Region North of Brazil and in southern Argentina.

Considering the chosen areas, it may be observed a population growth of $0.20 \%$ p.a. in Uruguay, $0.49 \%$ p.a. in Rio Grande do Sul and, respectively, 0.71\% p.a., $0.72 \%$ p.a., and $1.47 \%$ p.a. in the Argentine provinces of Corrientes, Entre Rios and Missiones. Rio Grande do Sul was the Brazilian state whose population had the lowest growth in the period. Uruguay had an even lower population growth, whereas Argentine provinces presented higher growth rates than those of Rio Grande do Sul and Uruguay. The analysis for Level III is shown in Figure 12. 


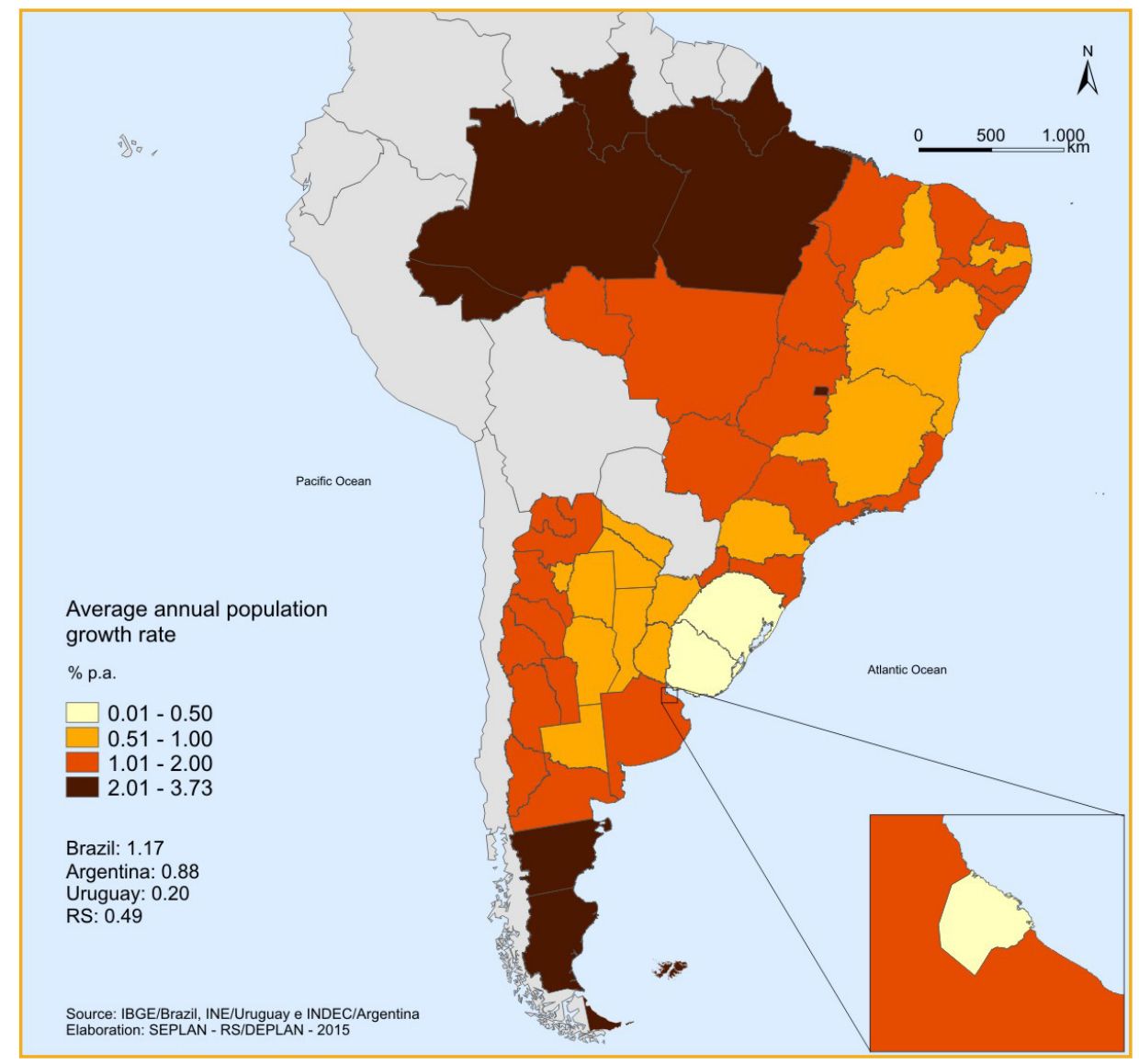

Figure II. Average annual population growth rate in Brazilian states, Argentine provinces and Uruguay - Comparable areas Level II.

Figure 12 identifies in detail this core of low population growth that is formed between northern Rio Grande do Sul and the interior of Uruguay, with negative growth figures in the periods considered. In Uruguay, only six departments record positive average annual rate for the period 2004-2011: Maldonado (2.19\% p.a.), Canelones ( $0.96 \%$ p.a.), San José (0.68\% p.a.), Colonia (0.68\% p.a.) and Río Negro and Salto, both with $0.20 \%$ p.a. Except for the last two, all are located near the Capital Montevideo, a region that concentrates more than half of the Uruguayan population. The other thirteen departments have lost absolute population, with rates ranging between $-0.01 \%$ p.a., in Paysandu, and $-0.85 \%$ p.a., in Artigas. 


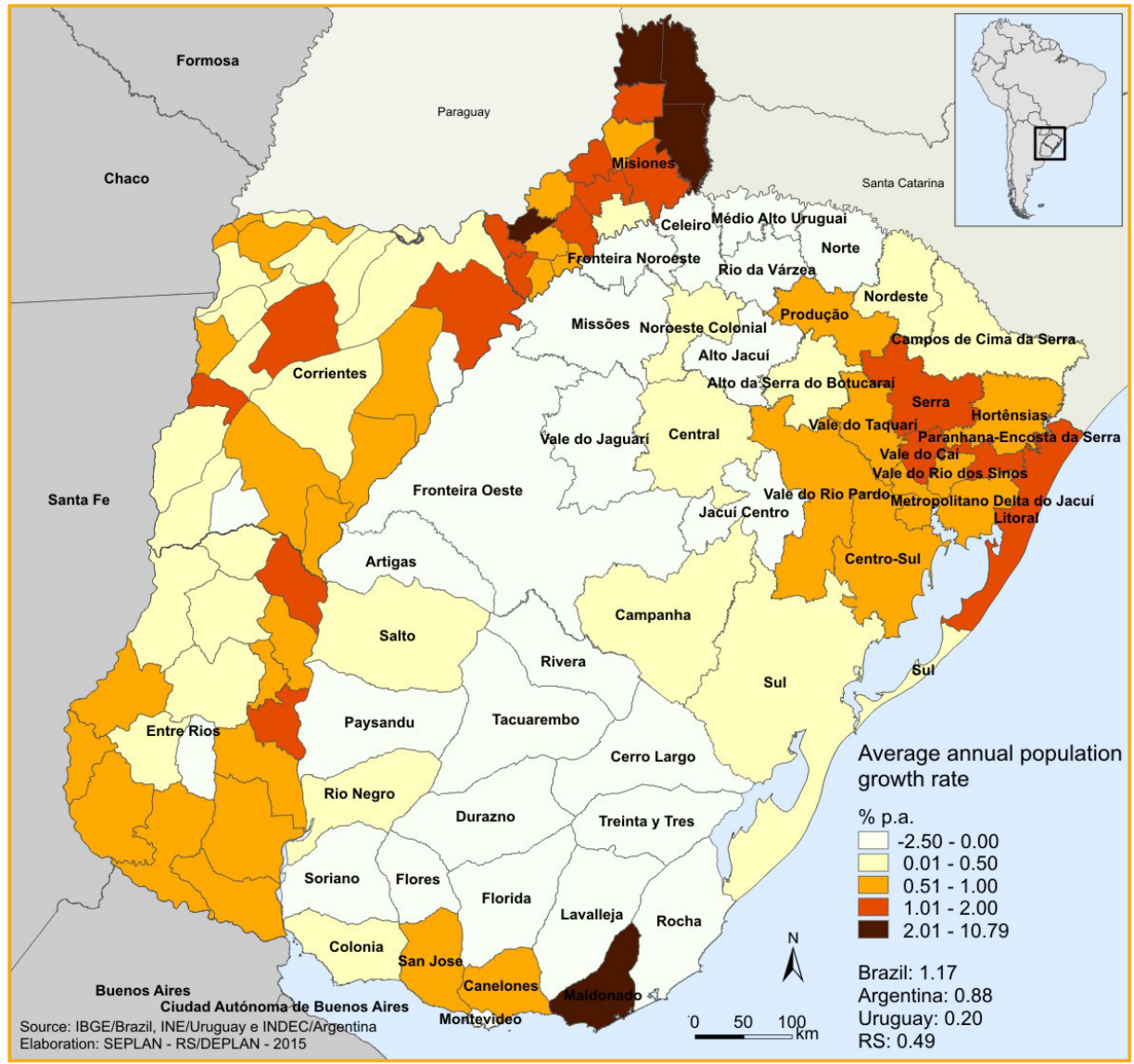

Figure 12. Average annual population growth rate in COREDEs and Argentine and Uruguayan departments - Comparable areas Level III.

In Argentina, the demographic situation in the border region with Rio Grande do Sul was heavily influenced by government policy. Settlement plans, incentives and constraints that occurred in some historical moments eventually had a significant impact on the border region with Brazil, both in Corrientes and in Misiones. It should be noted that, especially in the case of Misiones, population growth was heavily impacted by the migration of Brazilians, who settled there in an expressive amount between the decades of 1950 and 1970. In departments as San Pedro and Manoel Belgrano, the estimates show that $70 \%$ of the inhabitants are Brazilian or children of Brazilians, who settled there either because of the political instability experienced by Brazil during the military dictatorship, or by the search for new 
agricultural frontiers. At present, although these movements have diminished, these departments are still impacted by descendants of those immigrants (Ferrari, 2014).

Between 2001 and 2010, although some border departments of Argentina, when compared to the departments of Uruguay and to COREDEs in Rio Grande do Sul, presented higher levels of population growth, the provinces to which they belong, mainly Corrientes and Entre Ríos, had low population growth in relation to most other provinces in Argentine territory. Especially when compared to southern Argentina, which has been helped by incentives of government policies.

The geographic region that occupies the borders of the north, west and part of the south of Rio Grande do Sul is characterized by a process of population emptying. COREDEs Celeiro, Fronteira Noroeste, Missóes and Fronteira Oeste presented, in the period 2000-2010, negative population growth rates that ranged between $-0,57 \%$ p.a. and $-0,33 \%$ p.a.

In the north, on the border with Argentina - COREDEs Celeiro, Fronteira Noroeste and Missōes - the region is characterized by the presence of a large share of the population living in rural areas, which in many cases is still close to $50 \%$ of the total. Such population, especially the younger one, tends to migrate to more prosperous urban centers in search of work. Whereas in COREDE Fronteira Oeste, close to Uruguay, population loss is mostly associated to the population already living in the cities, where there are more than $90 \%$ of the inhabitants. Further south, Campanha region, in the border with Uruguay, although presenting a positive rate, had a low increase, only $0.04 \%$ p.a.

As in Uruguay, the emptying of these regions is opposed to others of greater economic dynamism and population concentration. Therefore, in the case of RS, a higher population concentration is verified in the eastern COREDEs, which polarize employment, workforce training and health services, consequently prone to a greater development.

Thus, it may be observed that migratory movements responsible for the decline of population in these border areas occur within the respective countries. Crossborder population movements are still of little significance. These cross-border movements tend to be intensified in the analysis of next censuses due to the entry into force of the Agreement on Residence for Nationals of States Parties of MERCOSUR, which has been bilateralized by Brazil and Uruguay on October 26, 2006. This agreement allows that the applicant be considered a permanent citizen two years after his/her legalization in the country (Lemos, 2013, p. 172). 


\section{SOME ECONOMIC AND TRANSPORT INFRASTRUCTURE ASPECTS OF THE BORDER OF RIO GRANDE DO SUL}

In Rio Grande do Sul, some features of the international border have significant influence on migratory movements towards the east of the State. Some aspects such as lack of integration of its infrastructure and economic characteristics do not contribute for the permanence of the border population in its place of origin.

In the border of Brazil and Uruguay, economic activities are dominated on both sides by extensive cattle breeding and rice cultivation. In the Uruguayan territory, forestry also stands out. Production of milk and fruit are common on both sides, and the last one has been recently introduced on the Brazilian side.

On the border with Argentina, the Brazilian side is more dynamic, with grain production and a well-structured agribusiness, with emphasis for the segment of agricultural machinery and implements. On the Argentine side, that comprises the provinces of Corrientes and Misiones, forestry dominates, and also breeding activities, although with low participation in the total production of the country.

Thus, the border region of Rio Grande do Sul is dominated by agricultural production, with middle and large estates and low incorporation of technology in the south, and small estates in the north, which also require greater dynamism. These economic characteristics are important for the population emptying process observed, since the largest economic concentration of the State is located in the eastern portion of Rio Grande do Sul, represented by Porto Alegre-Caxias do Sul axis.

To these factors are added the infrastructural ones. The articulation between Rio Grande do Sul and these countries occurs through the main modes: road, air, rail and water. Road transport is the one with more connections. In Rio Grande do Sul, these connections are made by BR-116, BR-101, BR-290 and BR-285 roads, according to Figure 13.

BR-116 enters the State by the municipality of Vacaria, through Caxias do Sul, Canoas, Pelotas and Jaguarão/Rio Branco. BR-101 crosses the State in north/south direction, in the coastal region, being interrupted, between the municipalities of Sáo José do Norte and Rio Grande, by the channel that connects Patos Lagoon with the Atlantic Ocean, and from the municipality of Rio Grande it continues until Chuí/Chuy. BR-290 and BR-285 connect the eastern part of Rio Grande do Sul 


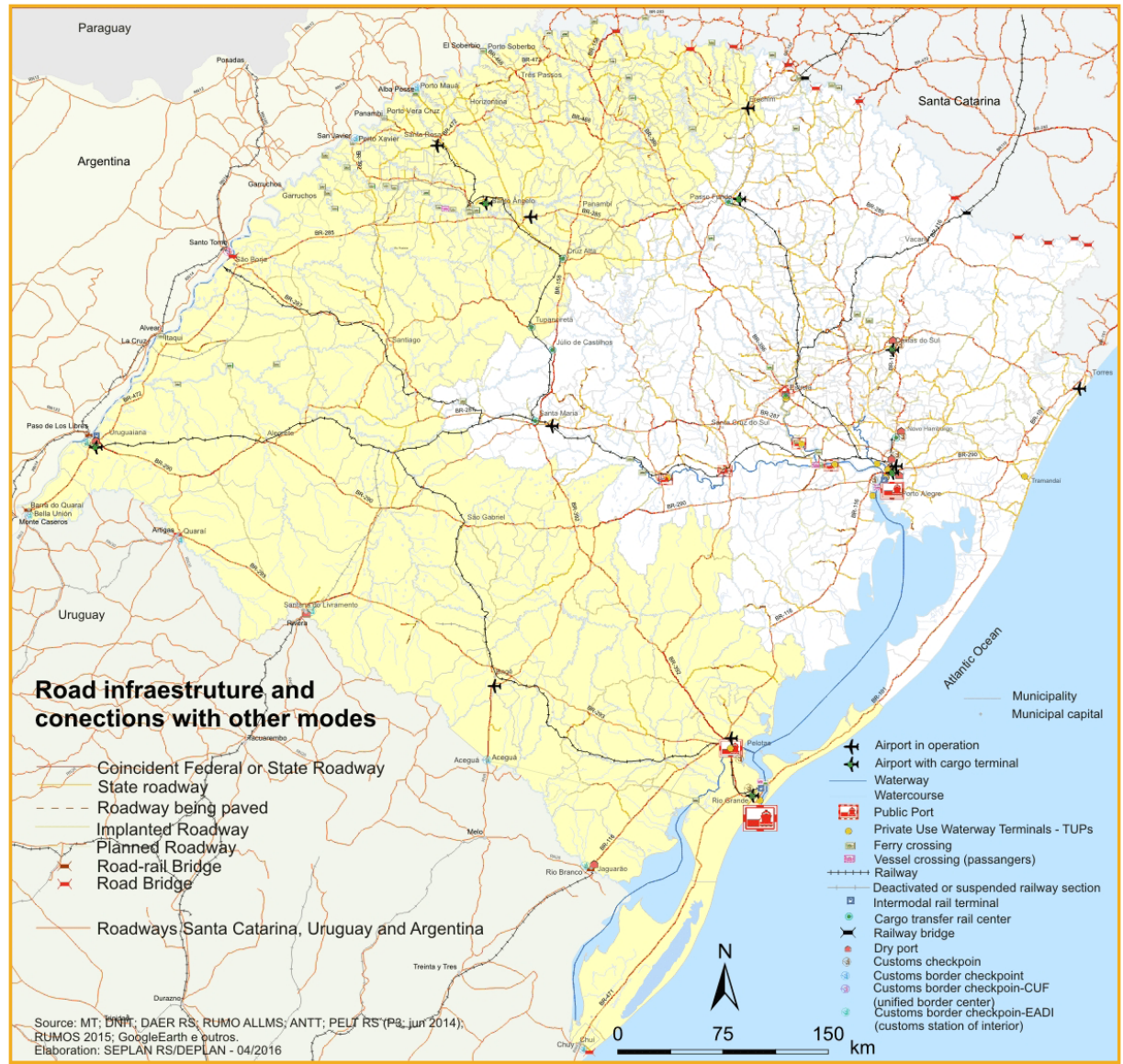

Figure 13. Road infrastructure and connections with other modes in the border region of RS

to Argentina and Uruguay, and BR-290 goes from RMPA -Regiáo Metropolitana de Porto Alegre (Porto Alegre Metropolitan Region), until Uruguaiana/Paso de los Libres, also connecting, through BR-180, the cities of Santana do Livramento and Rivera. BR-285 connects BR-116, from Vacaria until São Borja/Santo Tomé, from where it goes to Itaqui/Alvear, Uruguaina/Paso de Los Libres, and Barra do Quaraí/ Bella Unión, by BR-472 (Rio Grande do Sul, 2012). However, the absence of road links is observed in the northwest of the State, on the border with Argentina.

The main airway connections are between the airports of Porto Alegre, Montevideo and Buenos Aires. Whereas railway connections are organized through logistic platforms located in the municipalities of Santana do Livramento, 
Uruguaiana and São Borja. Nevertheless, it may be observed that several of these connections are deactivated, as in the case of the rail branch Cacequi-Santana do Livramento. Furthermore, it may be noted that the differences in gauges between Brazilian railways and those of their neighbors hamper greater integration by this mode.

In the waterway transport mode, the main connection is by coastal shipping between the ports of Buenos Aires, Montevideo, Rio Grande and Porto Alegre, and the Port of Rio Grande is the one with greater importance and potential for expansion. MERCOSUR Waterway, that passes through Jacuí, Taquari, Caí, Sinos, Gravataí, Camaquã and Jaguarão rivers, connecting with Patos Lagoon through Guaíba Lake, continuing through São Gonçalo Channel and Mirim Lake, presents a great potential for infrastructure integration between Brazil and Uruguay.

Therefore, as pointed out in the study Perfis Socioeconômicos dos COREDEs (Socioeconomic Profiles of COREDEs - Bertê et al., 2016), mainly the northwestern region of Rio Grande do Sul has a scarcity of transport infrastructure. This characteristic hinders the flow of local production, predominantly generated in small farms,contributing to its loss of competitiveness. The economic repercussions of the lack of infrastructure in this region may contribute to the observed population losses.

From the viewpoint of integration on a local scale, the most relevant factor is the existence of a significant network of twin-cities that characterizes the border of Rio Grande do Sul ${ }^{12}$. The ten cities that form this network are small urban agglomerations, connected to the large axis Buenos Aires/São Paulo, having as intermediary hubs Porto Alegre and Montevideo. They have a local integration that can be increased, as occurred with the creation of binational technical schools, in Santana do Livramento and Rivera, with the joint sanitation plan of Aceguá, in Brazil, and Acegua, in Uruguay, and with the Agreement for Permit of Residence, Study and Work, in force in the localities in the range of up to 20 kilometers on both sides of the Brazilian-Uruguayan border (Lemos, 2013).

12 Twin-Cities: Chuí-Chuy; Jaguarão-Rio Branco; Aceguá-Acegua; Santana do Livramento-Rivera; Quaraí-Artigas; Barra do Quaraí-Bella Unión on the border of Rio Grande do Sul and Uruguai; and Uruguaiana-Passo de los Libres; Itaqui-Alvear; São Borja-Santo Tomé, Porto Xavier-San Javier and Porto Mauá-Alba Posse on the border of Rio Grande do Sul and Argentina. 
Therefore, besides the economic factors linked to demographic issues and the consequent population emptying, infrastructure characteristics are also relevant. In the border with Uruguay, the dry border revives this issue. Whereas in the border with Argentina, the existence of the physical barrier represented by Uruguay River deeply hampers a greater dynamics in the border integration.

\section{FINAL CONSIDERATIONS}

The data analysis showed that, save for the specifics of each case, the demographic dynamics prevailing on the Brazilian side are similar to Argentine and Uruguayan ones. Although there are variations in the economic structure on the different sides of the border, all are marked by low demographic density and lack of economic dynamism. These characteristics, especially in the border of the State and Uruguay, are enhanced by the combination of elements as population ageing, and high emigration and low fertility rates.

According to the analysis, Rio Grande do Sul and its border region are in an intermediate position regarding the Demographic Transition process. If other Brazilian states and provinces of the Argentine border are considered, there is a less advanced stage of changes in the population profile, while in Uruguay this situation is already similar to that of developed countries, with an already aged population and low birth rates.

This situation requires special attention, especially from the State, which must propose policies so that this rupture does not generate negative socioeconomic effects. Policies aimed at the aging population and a new approach on early childhood and fundamental education are essential aspects in this new reality.

Therefore, it should be noticed that there are already long-term studies carried out by Rio Grande do Sul State Secretariat of Planning, Governance and Management - Futuro RS: Agenda de Desenvolvimento (Future RS: Development Agenda - Rio Grande do Sul, 2016) that envisage to provide the basis for public policies concerning this new demographic profile.

Regarding population growth, on the Argentine side, the province of Misiones differs from this characteristic. In the case of San Pedro and Manoel Belgrano departments, growth was historically associated to the migration of Brazilians in 
search of new agricultural frontiers. Whereas the south of this province is linked to the demographic policy of Argentine government, which took place from the 1980s on.

In Uruguay, a population movement in the north-south direction may be observed, towards the departments near Montevideo. This movement seems to occur due to similar factors to those of the southern border of Rio Grande do Sul, such as economic dominance of agriculture of middle and large sized estates, with slow incorporation of technology, besides low industrial development. However, more detailed studies on the similarities between economic structures of the border region between Brazil and Uruguay are still required.

In Rio Grande do Sul, the dominant population movement is in westeast direction, with the population leaving the border region. In the south, the aforementioned economic structure contributes for these movements of population departure. In the border with Argentina, mainly in the northwest, an agriculture structure of small and middle sized estates predominates, what also seems to offer little appeal to the settlement of the population. However, the region of Santa Rosa has a very dynamic industry of agriculture machinery and implements.

Besides the economic factors connected to demographic emptying, lack of infrastructure is also significant, mainly in the northwest region of Rio Grande do Sul. The difficulties of integration with Argentina, as well as the relative isolation of that region also influence the demographic dynamics observed.

\section{REFERENCES}

Badie, B. (1995). O fim dos territórios: ensaio sobre a desordem internacional e sobre a utilidade social do respeito. Lisboa: Instituto Piaget.

Bertê, A.M. A. et al. (2016). Perfis Socioeconômicos dos COREDEs. Boletim Geográfico do Rio Grande do Sul, 26, 5-1070. Retrieved from <https://revistas.fee.tche.br/index.php/boletim-geografico$\mathrm{rs} /$ issue/view/23>

Caetano, G. (2011). El Uruguay internacional y la región: apuntes históricos y desafíos vigentes.In: Brasil-Uruguai: os próximos 20 anos. Brasília: Fundação Alexandre de Gusmão.

Cargnin, A. P. et al. (2014). Quinze anos de transformaçôes na economia e sociedade gaúchas contados pelas páginas do Atlas Socioeconômico do RS. Boletim Geográfico do Rio Grande do Sul, 24, 29-62. Retrieved from <https://revistas.fee.tche.br/index.php/boletim-geografico-rs/article/ view/3195> 
Cuisinier-Raynal, A. (2001). La frontière au Pérou entre fronts et synapses. L'espace géographique, 3(30), 213-230.

Ferrari, M. (2014). Políticas migratórias do Estado Nacional argentino frente a migração brasileira no nordeste de Misiones. Perspectiva Geográfica 9(11). Retrieved from <http://saber. unioeste.br/index. $\mathrm{php/pgeografica/article/view/11677>}$

Foucher, M. (2009). Obsessão por fronteiras. São Paulo: Radical Livros.

Foucher, M. (1991). Fronts et frontières: un tour du monde geopolitique. Paris: Fayard.

Jardim, M. L. and Barcellos, T.M. (2011). Migraçôes no Rio Grande do Sul. Revista Paranaense de Desenvolvimento, 121, 133-147. Retrieved from <http://www.ipardes.pr.gov.br/ojs/index.php/ revistaparanaense/article/view/429>

Lemos, B. O. (2013). A Nova Agenda para Cooperação e Desenvolvimento Fronteiriço entre Brasil e Uruguai: repercussöes territoriais nas cidades-gêmeas da Sant'Ana do Livramento e Rivera. (Master's thesis). Retrieved from <http://hdl.handle.net/10183/76852>

Magnoli, D. (1997). O corpo da pátria: imaginaçâo geográfica e política externa no Brasil (1808-1912). São Paulo: Editora da UNESP.

Raffetin, C. (1986). Élements pour une théorie de la frontière. Diogène, 34(134), 3-21. Retrieved from <https://archive-ouverte.unige.ch/unige:4348>

RIO Grande do Sul. (2014). RS 2030: Agenda de Desenvolvimento Territorial. Porto Alegre: SEPLAG; FEE. Retrieved from <https://www.fee.rs.gov.br/publicacoes/rs-2030-agenda-de-desenvolvimentoterritorial/>

Rio Grande do Sull. (2012). Plano de Desenvolvimento e Integração da Faixa de Fronteira do Estado do Rio Grande do Sul - PDIF/RS. Porto Alegre: Governo do Estado do Rio Grande do Sul/Assessoria de Cooperação e Relaçóes Internacionais. Retrieved from <http://planejamento.rs.gov.br/upload/ arquivos/201604/11112501-pdif-rs-versao-final-site-relinter.pdf>

Rio Grande do Sull. (2016). Futuro RS: Agenda de Desenvolvimento. Caderno 2: O envelhecimento da população gaúcha e as consequências e desafios para as políticas públicas: saúde e educação. Porto Alegre: Governo do Estado do Rio Grande do Sul/ Secretaria de Planejamento, Governança e Gestão. Retrieved from <http://planejamento.rs.gov.br/futuro-rs>

Rückert, A. A., Carneiro Fillho, C.P. and Uebel, R.R.G. (2015). Cenários de Transfronteirizaçôes na América do Sul: alguns exemplos de pesquisas recentes. GeoPantanal,10(18), 159-181. Retrieved from <http://seer.ufms.br/index.php/revgeo/article/view/936> 



\section{MIGRATORY DYNAMICS AND TRANSBORDERING IN LA PLATA BASIN: AN OUTLOOK AT THE TRANSNATIONAL MIGRATION OF HAITIANS AND SENEGALESES}

\section{Roberto Rodolfo Georg Uebel}

\section{ABSTRACT}

With the saturation of models for the reception and integration of immigrants in the Northern Hemisphere, namely in the United States, United Kingdom and European Union, and the consequent migration and refugee crises, La Plata Basin has presented itself as an alternative to several new groups, among them, the Haitians and Senegalese, those of greater expression - according to the official statistics and estimates of contemporary studies. In this sense, this chapter analyses the dynamics of these two specific groups, considered transnational immigrants by contemporary literature, and their repercussions in the transbordering regions of Argentina, Bolivia, Brazil, Paraguay and Uruguay. It also identifies the immigration booms on these countries in the period from 2010 to 2016, as well as the occurrence of cycles of arrival, settlement and remigration within the macro-regional context. Finally, using the instruments of thematic mapping and statistical analysis of migration, the text is concluded with a description of the profile of trans and international migrations in La Plata Basin, their relations with the borderlands and their perspectives regarding the political, economic and social changes during this transition period including demographic and regional disruption.

KEYWORDS International migrations, migratory dynamics, La Plata Basin. 
The process herein approached started with the collapse of the reception and integration models of immigrants and refugees in traditional receiving countries from Northern Hemisphere, for example, United Kingdom, United States of America and member countries of the European Union - in particular France, Spain and Hungary. At the end of the decade 2010, there were new alternatives to the potential immigrants, among them, Brazil,strong at that period. Therefore, after the cyclical crisis, they reached this regional power and the nations of $\mathrm{La}$ Plata Basin and Latin America as well. This chapter begins with the brief narrative above, in order to justify the "new migrations" directed to Brazil; those increased between 2010-2014, according to Uebel (2017), and between 2014 and 2016 in the others states of La Plata Basin'1 Argentina, Bolivia, Paraguay and Uruguay. These new migrations had a background built by economic, political, social and conjectural motivations; thus reshaping the border dynamics and practices in this peculiar region of Latin America.

Then, the hypothesis which we will discuss along this chapter is that the increase of migratory flow directed to the region of La Plata Basin occurred due to repulsive conjectural factors in the Northern Hemisphere combined with a coincident economic, labor and social dynamism in Latin America and La Plata Basin, these were attractive to immigrants and alternative to the traditional receiving countries. In addition, the bankruptcy of the Brazilian model of integration and accommodation of these immigrants lead to remigrations to the Platine neighbors and other countries.

However, our analysis will point out that, in spite of the reconfiguration of the borders and the transbordering economy, recurring practices of the Northern Hemisphere, such as xenophobia, regional-nationalism and aversion to immigrants - mainly the ones of black ethnic origin - we will find reverberation and acceptance in Platine receiving societies; thereafter, this critical alert is important before we proceed the discussions of the chapter.

\footnotetext{
1 According to the understanding of the Organization of American States and the Treaty of the River Plata Basin (BRAZIL, 1970), we consider Argentina, Brazil, Bolivia, Paraguay, and Uruguay as Participating States of La Plata Basin, since they are bathed by the rivers that are part of this basin: Paraná, Paraguay and Uruguay. In geographic literature there is no consensus on the insertion of Bolivia as a political actor in this regionalization; however, Bolivia's presence is essential for fully understanding migratory and remigratory dynamics.
} 
The choice of two singular groups - Haitians and Senegalese - among the dozens of "new groups" that migrate en masse (Baeninger, 2015) to La Plata Basin between the years 2010-2016 arises from two factors: 1) geo-cultural representation of these origin regions: Caribbean and African west coast; 2) perception and transbordering promotion in the Platine context, prviously only performed by the national groups of this own region, without outsiders.

However, these are not the nationalities highlighted in the migratory statistics rankings in the countries of La Plata Basin - Haitians represent around $2 \%$ of the total immigrants, while Senegalese less than $0,3 \%$ - their intensity and praxis call our attention in this analysis, in addition its migratory uniqueness to this region.

Vania Herédia (2015) points out, for example, that Senegalese's migration to Latin America occurred only in two moments, the first during the PortugueseSpanish slavery period, between XVI and XIV centuries, and the second moment only in the second decade of XXI, in other words, forced migration and now economic migrants or refuge migrations. Furthermore, as already mentioned, these two groups represent also, excepted all social, cultural and national particularities, the immigration dynamics of other Caribbean and African west coast nationals. According to official statistics, they represent a substantial percentage (around 20 to $30 \%$ ), depending on each La Plata Basin states.

Brazil, for example, stands out in Haitian immigration, around 56,000 immigrants - economics and humanitarian visa holders -, meanwhile Argentina leads the Senegalese ranking, with almost 6,000 immigrants, both in the same period, from 2010 to 2016. After these initial considerations that will be deepened along the chapter, it is important to discuss briefly about its division, as well as the methodological and quantitative issues - of data - that permeated the conduction of the research, which started simultaneously with the migratory boom in $2014^{2}$.

The structure of the text is divided in four sections, besides this Introduction and the Final Considerations, as well as the References used, in the end of the text. We intend to divide the analysis to provide didactic understanding of the processes and dynamics occurred with the Haitians and Senegalese migration in

2 Chapter resulting of the project "Transbordering in South America: territorial dynamics, regional development, integration and defense on the southern and the northern borders of Brazil", financed by Pro-Defense Fellowship of the Brazilian Ministry of Defense in cooperation with Coordination of Improvement of Higher Level Personnel. The author is grateful for public funding, derived from taxes paid by Brazilian taxpayers, responsible for the Brazilian scientific development. 
this proposed time frame, i.e., between 2010 - beginning of these migrations - and 2016, last year with complete available data.

Thereby, the first section "La Plata Basin Migrations: General Aspects" is divided in five sequential subsections, in which we will analyze briefly, around one page, the migratory profile of each five Platine countries, in order to provide as a background the analysis and the understanding of the following sections. In these subsections, we will prioritize the use of graphics and an introductory thematic cartography, to help the localization of the reader.

The second section titled "Haitian Migration in La Plata Basin" is dedicated to Haitian migratory processes in this region, as economic immigrants holders of Caribbean praxis, different from those verified so far in this geography dominated basically by intra-regional migrations of Mercosurean and Andean citizens.

The third section "Senegalese Immigration in La Plata Basin" uses both thematic cartography and demographic data analysis. In addition, it will point out the dynamics and the directions given by the quick Senegalese immigration - composed by economic migrants and (here a surprise) refugees - representatives of one highly dynamic region in the African continent, its west coast.

The last section encompasses the results of this research, under a criticalinternationalist perspective, entitled "Borders, Political, Economic and Social Changes". This section will identify and discuss resignification of borders in the Platine scope, as well as the political, economic, social and labor changes that lead Haitian and Senegalese remigration inside this region, and also to third parts, such as the United States and Canada, in the Northern Hemisphere.

Before we proceed the discussions of the chapter, it is necessary a brief digression about the concepts used in the text, as well as the acquisition and the use of the statistical data that support our analysis. Following the discussion models already performed by Oliveira (2012) and Garcia (2016), we prioritized a critical, descriptive and intuitive analysis (to the reader) of the identified phenomena, linking and inserting it in the political and economic conjuncture at the time of the analyzed facts.

In this way, the chapter uses the concepts of immigrant and economic immigration from Rocha-Trindade (1995) and of refugee from Moreira (2014). Therefore, in this analysis some categories are not considered such as political 
and environmental refugees, expatriates, temporary or provisional migrants, dual citizenship individuals and tourists with permanent visa.

In relation to the used data ${ }^{3}$, their obtainment translates the conduction of an imagined regional integration in La Plata Basin: bureaucratic, difficult and restrictive/excluding. The Brazilian data were obtained from Uebel's (2015) research and were updated through a request performed based on the Law of Access to Information to the Federal Police and Ministry of Justice.

The data from Argentina were obtained from National Direction of Migration (DNM, in Spanish), associated to the Ministry of the Interior, Public Works and Housing, the radicaciones are counted by this organ. In relation to data from the neighbor Uruguay, these were obtained from two different organs: National Direction of Migration (DNM, in Spanish), belonging to Interior Ministry and National Institute of Statistics (INE, in Spanish).

The data from Paraguay, accessed in a complete and fast way in comparison to the other countries, were obtained through the Law of Access to Information from that country, with National Direction of Migration of Interior Ministry. Lastly, the more peculiar and long obtainment of statistics occurred with Bolivia, whose form was in a more formal way - submission of a registered correspondence to the General Direction of Migration - the document with the answer took almost two months to be received by the researcher, evidencing the research difficulties when we venture out in the Latin America interrelated analysis.

We expect with this discussion to advance in the understanding of migratory dynamics, transbordering, economic and social, in the context of La Plata Basin, one of the regions that, according to Carneiro Filho (2016), had an economic great expansion and political visibility - in spite of crises, coups, breaks and impeachments - in the Southern Hemisphere along the last two decades, and still remains a great laboratory to be explored by Geographers, Economists, Internationalists and Political Scientists, in the light of the comprehension of the Planet and the third millennium. After all, this region of the world is a mirror to the praxis of other nations (Prado; Pellegrino, 2014).

3 All the original statistical tables, as well as the documents and forms used to obtain the data, are available for consultation at this link: <https://www.dropbox.com/sh/pt6hby8wgawhjfg/ AABmP011pe0jkCLHImxfUCoba?dl=0>. 


\section{LA PLATA BASIN MIGRATIONS: GENERAL ASPECTS}

In this section we will briefly analyze the general aspects and the international migrations panorama in the five States of La Plata Basin. This part of the text is relevant since it provides the background for the understanding of the Haitian and Senegalese migratory dynamics that will be discussed in the following two sections.

In this regard, it is highlighted that the compilation of the migratory quantitative data in the American system has been receiving special emphasis in the last years, with distinction to the studies performed by the international organizations such as Organization of American States (2015), Economic Commission for Latin America and the Caribbean (Pizarro; Rivera, 2016), International Migration Commission (2012) and Organization for Economic Co-operation and Development (2012), evidencing the institutional engagement in these issues of regional and territorial integration in the context of La Plata Basin and, consequently, focused on the migrations.

In relation to the international migrations variation in these five countries, graphic 1 bellow points out the verified trends, influenced by its own cyclic dynamic on screen:

These data - that do not contemplate migrant stock of each country, with this methodological caveat -, indicate, therefore, the high grade of remigration meantime in La Plata Basin, with Brazil being the initial attraction pole to Caribbeans and Africans, Argentina and Paraguay the intermediate poles (or secondary), Bolivia and Uruguay, the transitory alternative destinations (DAT, in Portuguese), and we will discuss in each subsection, by country. 


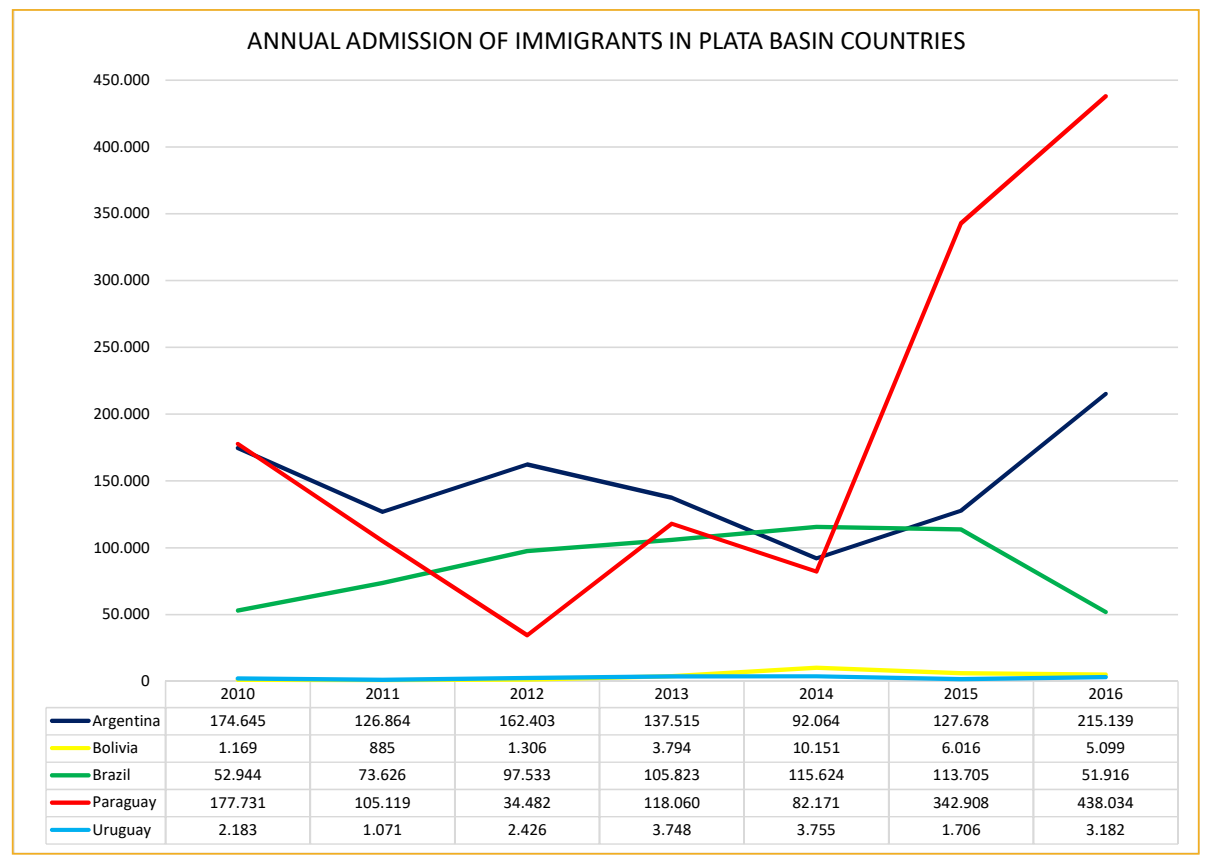

Graphic I. Annual entrance in La Plata Basin countries.

Source: Data collected by the author using quantitative information obtained from the following organs: Dirección Nacional de Migraciones (Argentina), Dirección General de Migración (Bolivia), Departamento de Polícia Federal (Brazil), Dirección General de Migraciones (Paraguay), Dirección Nacional de Migración (Uruguay), Instituto Nacional de Estadística (Uruguay), Sistema Continuo de Reportes sobre Migración Internacional en las Américas (OAS) and United Nations, Department of Economic and Social Affairs, Population Division (2009). Trends in International Migrant Stock: The 2008 Revision (United Nations database, POP/DB/MIG/Stock/Rev.2008).

\section{ARGENTINA}

In spite of immigratory booms experienced both by Brazil and Paraguay in the analyzed period (2010-2016), Argentina, the second largest Platine economy, observed an increase in its immigratory flows after 2014, according to Graphic 2: 


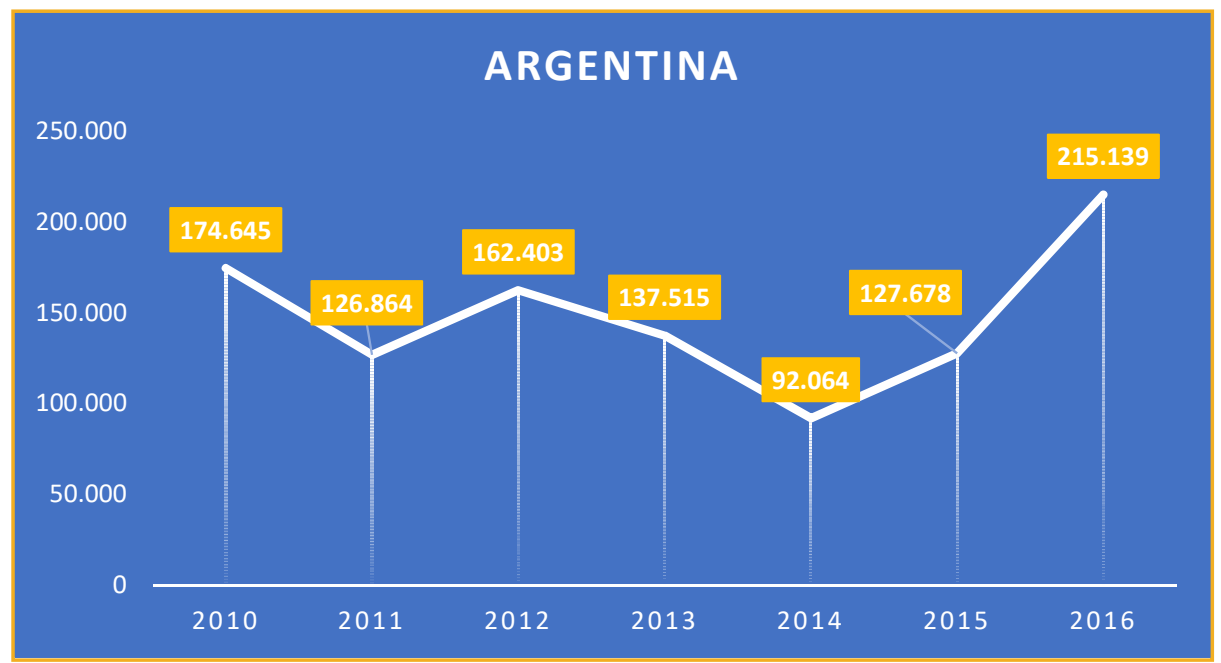

Graphic 2. Immigrant Annual Entrance in Argentina.

Source: Data collected by the author using quantitative information obtained from Dirección Nacional de Migraciones.

According to data collected by Sistema Continuo de Reportes sobre Migración Internacional en las Américas, from the American States Organization, the immigrant population in Argentina corresponds to about $4.5 \%$ of the total population of the country, a high index for Latin American standards (Castillo; Gurrieri, 2012) and similar to the European Union countries (Domenech, 2007). Between 2010 and 2016, the analysis period, Argentina received 1.03 million of economic immigrants.

In November 2006, OIM director, Brunson McKinley, recognized the modernizer and innovative aspect of the new Argentinean migratory law "Great Nation" as "world example" (INFOBAE, 2006). This law is one of the most modern and receptive to immigrants in the Southern Hemisphere context - instead of the new restrictive alterations imposed by Mauricio Macri administration in 2017 (Clarín, 2017) -, thus allowing the compliance of the immigratory main groups diversity in that country (Table 1 ): 
Table |

Immigrant entrance in Argentina by nationality 2011/2015.

\begin{tabular}{|c|c|c|c|c|c|c|c|}
\hline \multicolumn{8}{|c|}{ Temporary } \\
\hline Nationalities & 2011 & 2012 & 2013 & 2014 & 2015 & Total & $\%$ \\
\hline Paraguayan & 54,775 & 66,583 & 54,615 & 33,845 & 46,008 & 255,826 & $39.57 \%$ \\
\hline Bolivian & 31,471 & 42,008 & 33,454 & 20,251 & 27,964 & 155,148 & $24.00 \%$ \\
\hline Peruvian & 20,734 & 28,057 & 19,243 & 10,857 & 13,829 & 92,720 & $14.34 \%$ \\
\hline Colombian & 7,568 & 12,354 & 12,628 & 6,218 & 12,406 & 51,174 & $7.92 \%$ \\
\hline Chilean & 2,662 & 3,024 & 2,843 & 2,183 & 2,864 & 13,576 & $2.10 \%$ \\
\hline Uruguayan & 1,443 & 2,199 & 2,429 & 2,064 & 2,498 & 10,633 & $1.64 \%$ \\
\hline Venezuelan & 1,010 & 1,132 & 1,294 & 1,777 & 4,707 & 9,920 & $1.53 \%$ \\
\hline Ecuadorian & 1,336 & 1,362 & 1,564 & 1,393 & 2,356 & 8,011 & $1.24 \%$ \\
\hline Dominican & 197 & 203 & 2,216 & 1,702 & 1,291 & 5,609 & $0.87 \%$ \\
\hline North American & 431 & 478 & 591 & 1,339 & 1,846 & 4,685 & $0.72 \%$ \\
\hline Spanish & 489 & 581 & 723 & 1,294 & 1,363 & 4,450 & $0.69 \%$ \\
\hline Chinese & 812 & 653 & 475 & 1,204 & 1,210 & 4,354 & $0.67 \%$ \\
\hline Senegalese & 9 & 4 & 1,579 & 1,497 & 1,170 & 4,259 & $0.66 \%$ \\
\hline Mexican & 533 & 576 & 580 & 1,098 & 1,315 & 4,102 & $0.63 \%$ \\
\hline French & 402 & 435 & 405 & 776 & 1,023 & 3,041 & $0.47 \%$ \\
\hline Brazilian & 855 & 499 & 490 & 461 & 732 & 3,037 & $0.47 \%$ \\
\hline Italian & 208 & 245 & 282 & 479 & 627 & 1,841 & $0.28 \%$ \\
\hline South Korean & 130 & 125 & 95 & 544 & 470 & 1,364 & $0.21 \%$ \\
\hline Haitian & 187 & 206 & 162 & 282 & 329 & 1,166 & $0.18 \%$ \\
\hline German & 178 & 171 & 157 & 283 & 347 & 1,136 & $0.18 \%$ \\
\hline Other nationalities & 1,434 & 1,508 & 1,690 & 2,517 & 3,323 & 10,472 & $1.62 \%$ \\
\hline Total Temporary & 126,864 & 162,403 & 137,515 & 92,064 & 127,678 & 646,524 & $100.00 \%$ \\
\hline \multicolumn{8}{|c|}{ Permanent } \\
\hline Paraguayan & 57,034 & 56,635 & 62,972 & 45,164 & 58,225 & 280,030 & $39.57 \%$ \\
\hline Bolivian & 36,331 & 31,963 & 34,083 & 26,889 & 31,996 & 161,262 & $24.00 \%$ \\
\hline Peruvian & 17,284 & 17,909 & 20,070 & 15,405 & 16,074 & 86,742 & $14.34 \%$ \\
\hline Colombian & 2,733 & 3,036 & 4,614 & 4,020 & 8,496 & 22,899 & $7.92 \%$ \\
\hline Brazilian & 3,675 & 4,260 & 4,133 & 4,158 & 5,317 & 21,543 & $2.10 \%$ \\
\hline Uruguayan & 1,809 & 2,065 & 2,381 & 1,960 & 2,391 & 10,606 & $1.64 \%$ \\
\hline Chilean & 1,990 & 2,060 & 2,177 & 1,879 & 2,082 & 10,188 & $1.53 \%$ \\
\hline Chinese & 1,719 & 1,084 & 1,200 & 1,662 & 1,760 & 7,425 & $1.24 \%$ \\
\hline
\end{tabular}


Cont.

\begin{tabular}{lccccccc}
\hline \multicolumn{7}{c}{ Permanent } \\
\hline Spanish & 734 & 930 & 962 & 847 & 816 & 4,289 & $0.87 \%$ \\
Dominican & 895 & 1,159 & 907 & 595 & 719 & 4,275 & $0.72 \%$ \\
Venezuelan & 500 & 779 & 991 & 859 & 1,091 & 4,220 & $0.69 \%$ \\
Ecuadorian & 514 & 616 & 723 & 540 & 959 & 3,352 & $0.67 \%$ \\
North American & 724 & 726 & 627 & 567 & 683 & 3,327 & $0.66 \%$ \\
Italian & 293 & 335 & 335 & 309 & 346 & 1,618 & $0.63 \%$ \\
Mexican & 330 & 325 & 253 & 274 & 377 & 1.559 & $0.47 \%$ \\
French & 241 & 199 & 201 & 168 & 212 & 1,021 & $0.47 \%$ \\
Cuban & 142 & 132 & 170 & 189 & 325 & 958 & $0.28 \%$ \\
German & 146 & 124 & 126 & 97 & 128 & 621 & $0.21 \%$ \\
Russian & 84 & 75 & 95 & 75 & 112 & 441 & $0.18 \%$ \\
Ukrainian & 58 & 49 & 64 & 44 & 82 & 297 & $0.18 \%$ \\
Other nationalities & 1,086 & 1,096 & 1,135 & 1,087 & 1,363 & 5,767 & $1.62 \%$ \\
\hline Total Permanent & $\mathbf{1 2 8 , 3 2 2}$ & $\mathbf{1 2 5 , 5 5 7}$ & $\mathbf{1 3 8 , 2 1 9}$ & $\mathbf{1 0 6 , 7 8 8}$ & $\mathbf{1 3 3 , 5 5 4}$ & $\mathbf{6 3 2 , 4 4 0}$ & $\mathbf{1 0 0 . 0 0 \%}$ \\
\hline
\end{tabular}

Source: Dirección Nacional de Migraciones

Another issue that deserves emphasis, in this brief compilation about the international migrations panorama to Argentina, is the entrance points of these immigrants, that occur mostly through land borders of the country with Bolivia, Paraguay and Uruguay, exactly their Platine neighbors.

According to the document Panorama Movimientos Migratorios, from National Migration Direction (Argentina, 2016), approximately $80 \%$ of the immigratory flows in Argentina occur mostly through land borders with the other La Plata Basin countries.

In this way, it is different when comparing to Brazil, which had the land borders reconfigured since the dynamism of international migration; Argentina observed an enhancement of the migration networks and immigrants and refugees services in its land border posts, according to Caggiano (2003).

We highlight, finally, the physical and institutional infrastructure in Argentina that may serve as a model to the other Platine countries in the migratory issue, whereas it accommodates, as seen above, a multicultural and diverse immigrant stock, modern legislations, qualified border apparatus and transbordering practices 
reported in its own culture and macro-regional economy (Mármora, 2016). A huge contrast will be found in the following subsection, with the analysis of immigratory reality in Bolivia.

\section{BOLIVIA}

The Plurinational State of Bolivia, together with Uruguay, is one of the transitory alternative destinations, or DAT (in Portuguese), as was mentioned before, i.e., this country is not the main destination or option to the international migrants in the twenty-first century; however, this country is an alternative transitory territory, arisen through the reimmigration experiences of its neighbors, in particular Brazil and Argentina.

In comparison with the other five Platine states, Bolivia is the one which shows the second low immigratory flow in the period from 2010 to 2016, according to the Graphic 3, only behind Uruguay.

Graphic 3 shows, therefore, a total number of 28,000 temporary and permanent immigrants in this period of 6 years, irrelevant to the Latin American context, but pertinent when analyzing the groups that compose it.

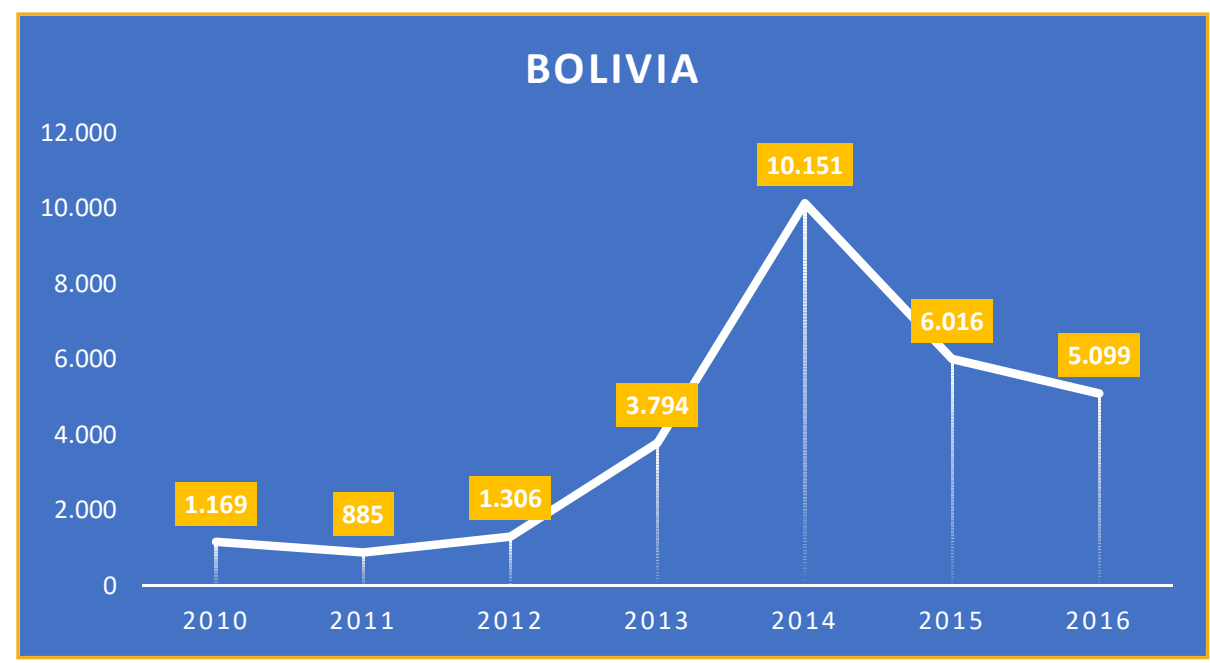

Graphic 3. Annual entrance of immigrants in Bolivia.

Source: Data compiled by the author from quantitative information obtained from Dirección General de Migración (Bolivia). 
The Organization of American States (2015) indicates that Bolivia immigration varied between 18-27 thousand individuals from 2010 until 2012, reaching 22 thousand in 2013 with constant growth. More than $50 \%$ of temporary immigration is due to international agreements, essentially Mercosur.

Another Bolivia's singularity factor in Platine scope is its role as transit territory to Caribbean, Asiatic and Africans enhanced flows to Brazil, Argentina and Paraguay (Mamed, 2016) - the latter still keeps that feature in a lesser degree. Nevertheless, Evo Morales' populist government (Carrizo, 2009) acted in favor of migratory legislation reformulation aiming migrations (even transitory) rule in country economy.

According to OAS (2015), financial remittances represent about $5 \%$ of Bolivian Gross Domestic Product. For example, in 2013, Bolivia received 1.18 billion dollars in migrant remittances what represents an increase of $8 \%$ in comparison to the previous year, overcoming other Platine countries (Fajnzylber; Lopez, 2008).

Since 2012, new Bolivian migration and refuge law privileges migrants protection (economic and refugee) in its articles highlighting the following rights: family reunification, municipal elections participation, worship and religious freedom, interpreter support - in addition to recognizing politic manifestation and immigrant associations and migration motivated by climatic changes, previously unheard of throughout America - which had favored Haitian and Senegalese flows at this country.

Despite jurisprudential innovations, Bolivia is the La Plata Basin country with the lowest human development index, counting on economic, social, political and institutional severe infrastructure deficiencies - reflected in difficulty to collecting data, as mentioned before.

In spite of underdevelopment remnants, this Andean country role is more than an economic or legal migration forum (permanent, temporary or transitional), it is also logistic - according to field research at the country between 2014 August and 2015 May - due to its condition of main provider of "new groups" towards Brazil, as seen in Figure 1.

It is important to emphasize that Bolivia has a large number of nationals - or expatriates according to current literature (BERRY; BELL, 2011) - inside other La Plata Basin countries,since Argentina, Brazil, Paraguay and Uruguay receive 


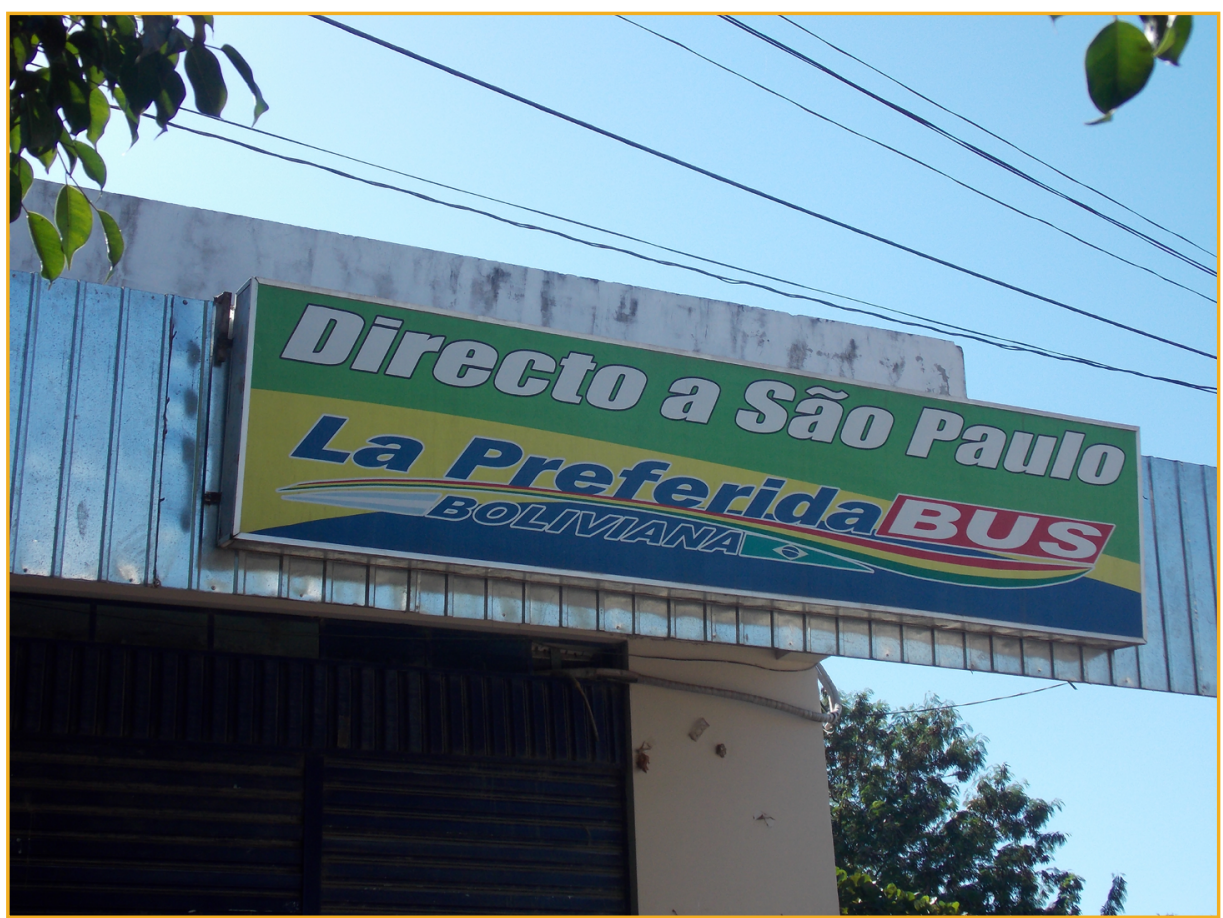

Figure I. Bolivian bus company advertisement showing routes to Brazil - used mostly by Bolivian, Haitians, Senegalese and Peruvians immigrants.

Source: Author's photography.

immigrants, refugees and serve as political asylum - because of political instability and economic and social underdevelopment of this multicultural and multiethnic country.

\section{BRAZIL}

Among five Platine countries, Brazil has the greatest territorial extension, population, Gross Domestic Product and particularities - plus crisis - related to two decades of a real giant, a regional power.

Constituted, since the sixteenth century, of varied ethnicities, nationalities and people, by means of migration (forced - slavery, economic and refugee of two Great Wars and due to hunger), Brazil and its society are defined as multicultural; 
definition followed by increase (double) immigratory flow between 2010-2014 and declining due to the biggest economic and political crisis occurred in 2015 culminating in a democratic break in 2016 (Jinkings; Doria; Cleto, 2016) with the irregular dismissal of president, economist and ex-guerrilla Dilma Rousseff.

Graphic 4 clearly shows another break in migratory flow in 2016, that fell by half when compared to the preceding year. However, Brazil was the biggest receiver of southern hemisphere immigrants since 2007 (UEBEL, 2015).

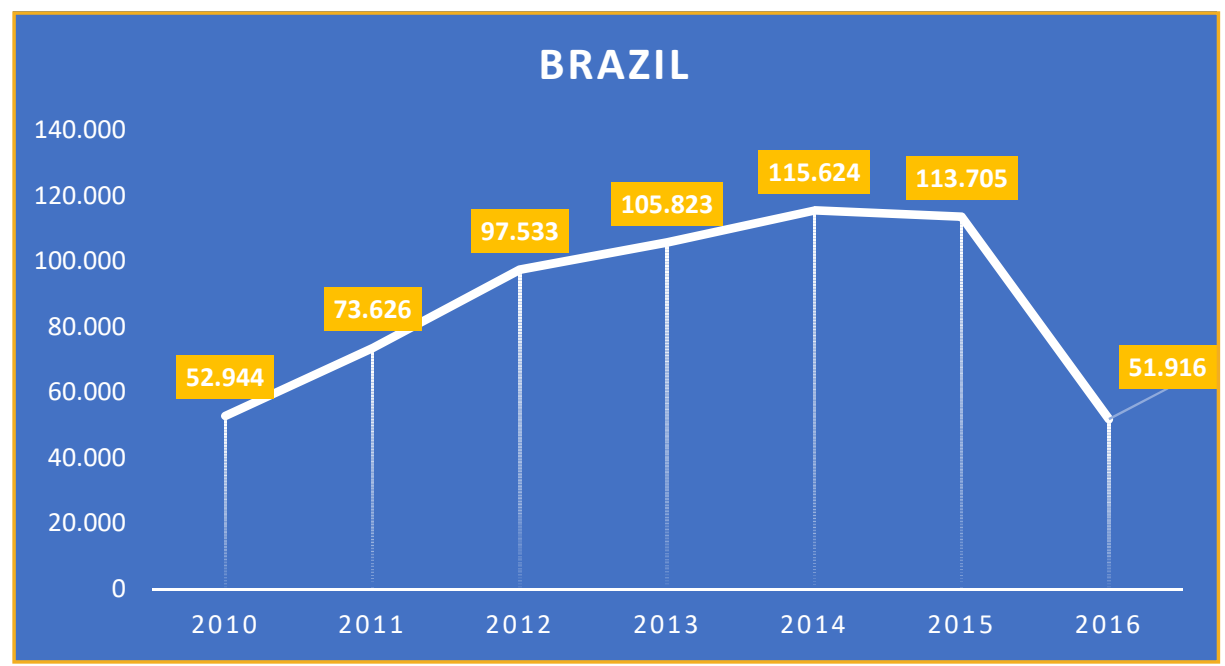

Graphic 4. Brazil annual immigrant entrance.

Source: Data compiled by the author from quantitative information obtained from Departamento de Polícia Federal and Ministério da Justiça.

Regarding transnational migration insertion to Brazil in La Plata Basin context, it is impossible to forget the reconfiguration - or resignification - of South, Midwest and North regions border lands, which became mainly front door to Caribbeans, Africans, Asians, and even Andean and Mercosurean migratory flows, traditional migrants since the eighteenth century.

If, in the past, migrations to Brazil occurred mainly by sea, Germans, Italians and Japanese cases during the nineteenth century or by air such as Palestinians, Syrians and Afghans cases in the twenty-first century, now re the roads - sometimes unpaved - that drive Haitians, Senegalese, Bengali, Malaysians and other groups towards the South and Southeast regions of the country, as wll as their dreams and motivations. 
Rückert, Carneiro Filho and Uebel (2016) point that the migratory boom occurrence in Brazil is due to its economic increase attached to active and haughty foreign policy (Amorim, 2015) and a mostly receptive migratory agenda than other regional powers like Canada and Australia, for example, and not so excluding like the United Kingdom, the United States and European Union members.

The following map (Figure 2) represents the origin of immigratory groups who chose Brazil for its apparent economic, labor, social and, if not, political welfare:

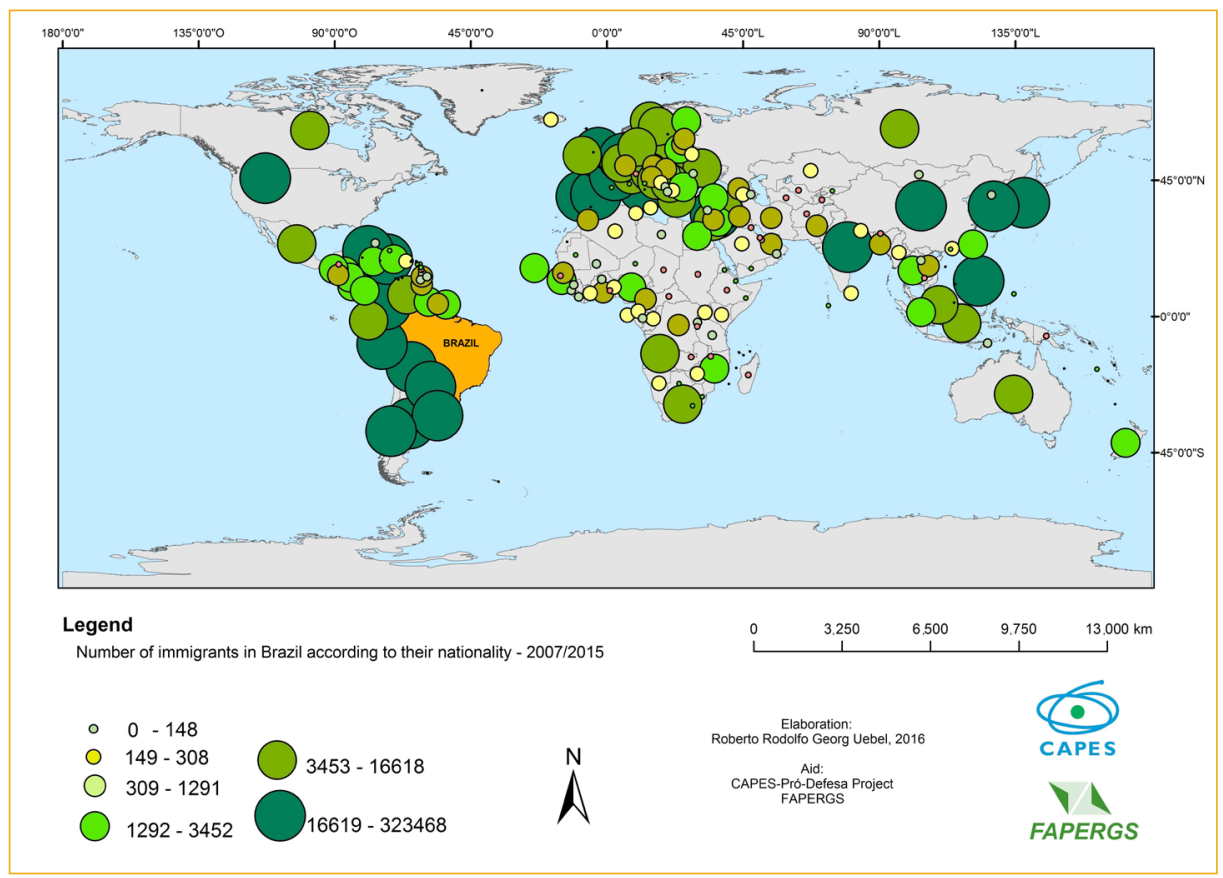

Figure 2. Immigrant quota in Brazil according to country of origin - 2007/2015.

Source: Compiled by the author.

Previous cartographic illustration shows that more than two hundred nationalities migrated to Brazil in a short period - when compared with the past great "migratory waves" as pointed by Piore (1979). Literature often refers to these mass migrations as a reflection of Brazil's projection in the international system, a legitimate global player on the migration agenda previously restricted to great economic powers.

However, after Dilma Rousseff's reelection political crisis from October 2014 - simultaneously with Migration Nation Strategy by means ofthe ${ }^{\text {st }}$ National 
Conference about Migration and Refuge - and with its peak in 2016 with final dismissal that reverberated in a crisis cycle: political, economic, labor and social migratory crisis.

Unemployment rate in Brazil jumped from $6.7 \%$ in 2010 - less than the majority of the European bloc - to $8.4 \%$ in 2015, $11.5 \%$ in 2016 and 13.7 $\%$ in the first quarter of 2017 with direct impacts in migrants layoffs following logics pointed out by the International Labor Organization (ILO) and by the Organization for Economic Co-operation and Development(OECD): "The first to be dismissed are irregular immigrants", states José Salazar, economist at ILO. Jean-Christophe Dumont, economist at OECD, reinforces this statement. (Netto; Chade, 2009)".

If in the past Brazil was considered an Eldorado (Silva; Assis, 2016), from 2015 it has become a nightmare to immigrants and their relatives who bet their life savings and mental and physical efforts to cross continents looking for an opportunity of better life and social security, leading to remigration phenomenon.

Remigration, the immigration of an established immigrant from one country to another one than his birthplace - not to be confused with, as has happened to Argentina, Uruguay and Paraguay, mostly next Platine neighbors and with good economic and employability indexes in alternative to the far Canada and the traditional United States.

During unusual Michel Temer's administration - then Dilma Rousseff's vice president and running mate in 2010 and 2014 - a new migration law was approved. Law No. 13.445 from May 24 of $2017^{4}$ replaced the Foreign Statute (dating from dictatorial period), outdated and not commensurate with the migratory (and democratic) reality of the country.

Despite the efforts and advances made by the new Migration Law, important articles were vetoed by the president of the Republic, with a lower popularity than the unemployment rate, in light of the political and economic irony that prevails in the country, despite a risky "threat to the sovereignty and national security" with the arrival of foreigners, in the presidential words in veto of said law, demonstrating total ignorance of the new immigration reality of Brazil: a country of emigrants and remigrants, and with an immigrant stock representing about $0.9 \%$ of its total population, impacting directly on the other Platine states, as will be discussed. 
Paraguay draws attention of International Relations analysts, geographers and economists at the beginning of this century due to its political, economic and territorial dynamization compared to other Platine and Latin American countries.

Being a stable democracy - despite the legislative coup that deposed Fernando Lugo in 2012 (Bèle, 2012; Morin, 2012) - and maintaining greater economic growth, employability and human development indexes than Brazil, Paraguay stands as the most immigrant friendly country in La Plata Basin between 2010 and 2016 according to the following Graphic 5. Paraguay received about 1.3 million immigrants:

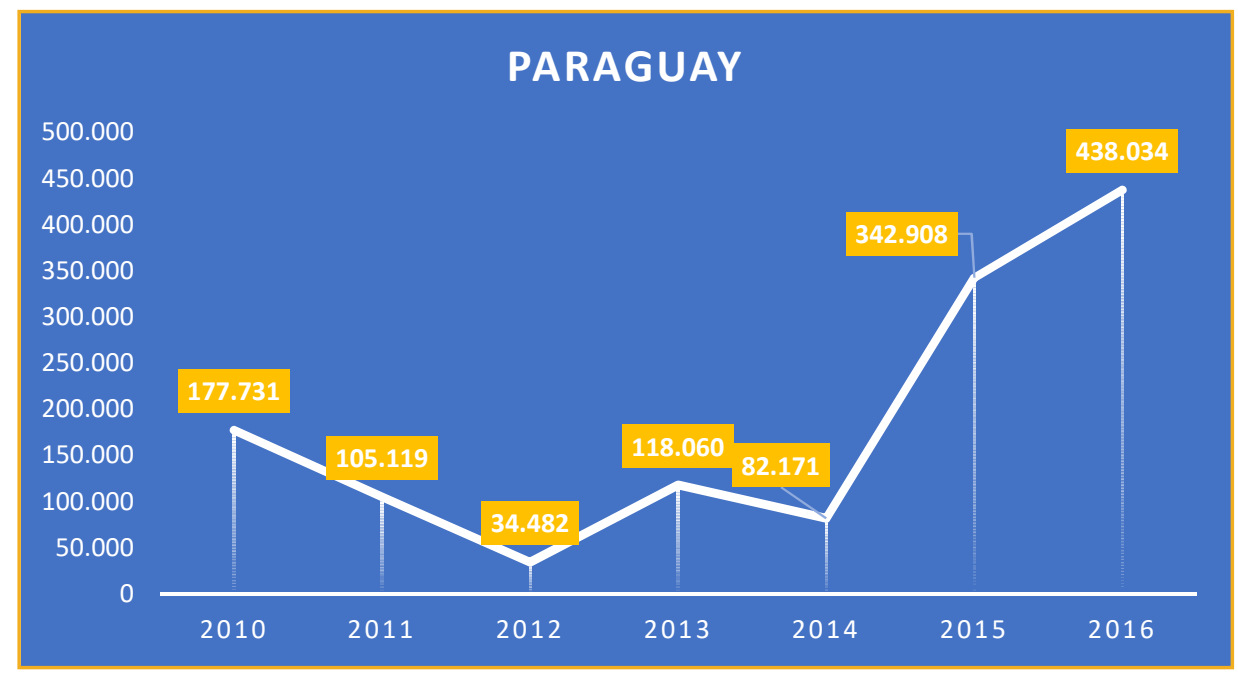

Graphic 5. Annual entrance of immigrants in Paraguay.

Source: Data compiled by the author from quantitative information obtained from Dirección General de Migracionesof Paraguay.

Together with Argentina, Paraguay is a secondary destination of international migrations (remigrations in this case) after the first boom experienced by Brazil in 2010. Official data obtained from Dirección General de Migraciones of Paraguay surely indicate the occurrence of two subsequent booms in Paraguay in the years 2015 and 2016. 
According to Oddone et al. (2011), hypothesis with which we agree, Paraguay absorbed not only Haitian and Senegalese remigrations but also a great flow of Bolivian, Taiwanese (without diplomatic relations with communist China), Syrians, Palestinians and lately Venezuelan refugees from Nicolas Maduro's dictatorship (Correia, 2016; Pintos, 2017).

For a long time, Paraguay used to be a traditional sender of migrants to Brazil, United States and Spain, but for the first time since its colonization that perceived before.

In relation to the Paraguayan territory, we also emphasize its strategic importance in the South American outline, as a "border" between Mercosurean and Andean nations. As we will see in the cartographies of the next sections, the flows of Senegalese and Haitians passed largely through Paraguay and its borders with Brazil, Bolivia and Argentina.

Public policy turned to immigrants and displaced people (forced and politics) has served equally as referential to other neighboring nations in Mercosur scope. For example, Paraguay government has had an active voice in public discussions and working groups pertinent to the subject.

The establishment of a National Refugee Commission (CONARE) and bilateral transbordering partnerships in the care of displaced migrants, including their own nationals, has been reflected in the reduction of two illegal acts traditionally found in La Plata Basin: smuggling and human trafficking. The Paraguayan-Brazilian border, in the cities of Ciudad del Este (Paraguay) and Foz do Iguaçu (Brazil) (Figure 3) saw physical and human reinforcement at their checkpoints in the last decade.

Despite the reduction of these two practices, we will see in the sections dedicated to the analysis of the Senegalese and Haitian migrations that many coyotes of Paraguayan nationality intermediated these flows with direction to Brazil between 2010 and 2014, what ended up moving Paraguayan economy itself, irregularly and criminally, as it has soared from $-1.2 \%$ in 2012 to $14 \%$ in 2013 , for example. 


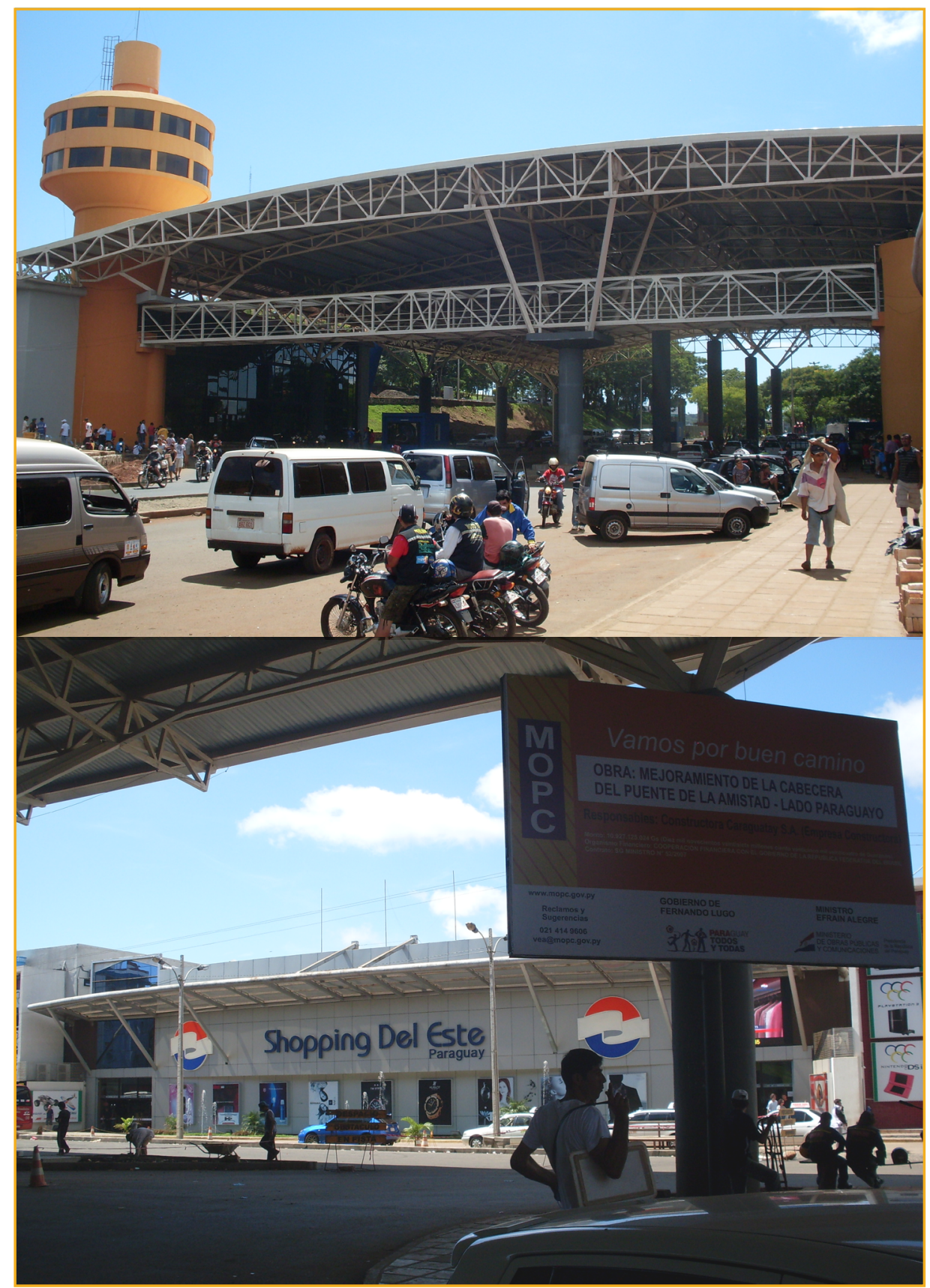

Figure 3. Modernized migratory and customs control post on Paraguay-Brazil border - Ciudad del Este.

Photographia: Camilo Pereira Carneiro Filho. 
It was a frequent phrase in ordinary conversation - mainly after economic crisis experienced by Argentina and Brazil: "I'm going to move to Uruguay". Uruguay has a smaller territory and the third largest Latin American HDI, it is an alternative transitory destination to Platine international migrants. Uruguay received about 18 thousand immigrants as seen in Graphic 6 in six years - an irrelevant quota in comparison with similar nations in development and size such as Suriname itself in South America, or the lowercase Andorra in Europe.

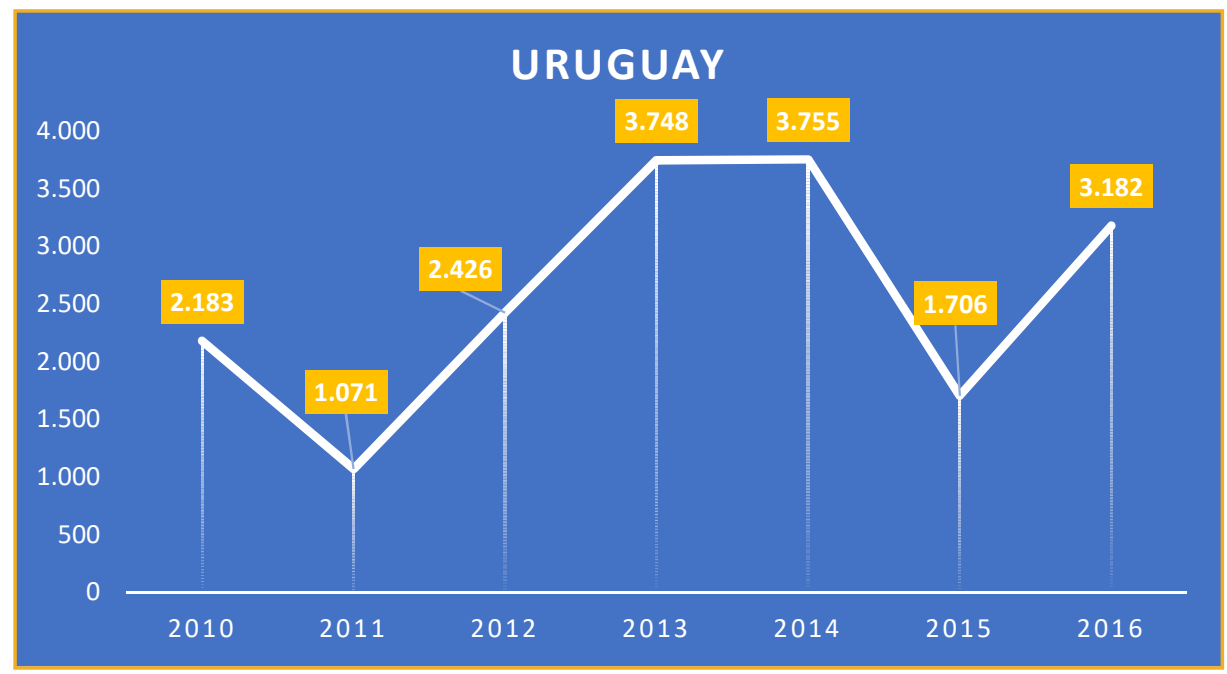

Graphic 6. Annual entrance of immigrants in Uruguay.

Source: compiled data by the author from quantitative information obtained from Dirección Nacional de Migración (DNM), Ministerio del Interior, and Instituto Nacional de Estadística (INE), both located in Montevideo.

Bengochea (2014) emphasizes that the small immigration flow within and towards Uruguay is justified more by a long-term lack in job opportunities and career building rather than by a hypothetical restriction of the country to international migrants, since this is one of the states with the largest number of expatriates in the world.

Uruguay has geostrategic importance in transbordering relations and mobility in La Plata Basin. Like Bolivia, it serves as transit territory to big flows between 
Brazil and Argentina and also as an alternative arrival port (mainly by sea) for Asian and African irregular migration - sometimes wrongly classified as clandestine or illegal -,since they travel in merchant ships often hidden or not registered (Arocena; Aguiar, 2007).

We will see in the next section that Uruguay has absorbed a considerable number of Haitians and Senegalese remigrated from Brazil or not accepted in Argentina, even more so after 2015, including its policy of welcoming forced and displaced migrants.

It is also worth noting the Uruguayan role in the reception and integration of the ex-prisoner migrants from the North American base of Guantanamo in Cuba, these of Arab-Muslim majority, that were received by Uruguay after its commitment with the United States (Correa, 2014), highlighting the humanitarian nature that Montevideo provides to the issues of human mobility.

Finally, the dynamization of the transnational borders of Brazil and Argentina with Uruguay, usually consolidated in squares, parks or small bridges, denotes the mobility character of Mercosurean citizens among these three Platine countries. Many of them with dual citizenship or even triple-identity, what characterizes in a very peculiar way the culture and economy of the state of Rio Grande do Sul in Brazil, the departments of Artigas and Rivera in Uruguay, and the provinces of Missiones, Corrientes and Entre Ríos, in Argentina, affecting the planning and territorial organization of these countries in a joint and structured way (Lemos, Rückert, 2014).

\section{HAITIAN IMMIGRATION IN LA PLATA BASIN}

Previously we briefly analyzed migratory profile of the five La Plata Basin states: Argentina, Bolivia, Brazil, Paraguay and Uruguay in order to build a background to understand two migratory "phenomena", of Haitians and Senegalese, as well as their dynamics in the Platine context.

Haitian immigration both in Latin American and in La Plata Basin is not the main migratory flow when analyzing a historical series of each of the countries (Uebel, 2015). However, it has higher growth and proportional participation in a short time, from 2010 on, and different motivations of those traditional Europeans and Asians as well as intra-regional migrants. 
This section is based in discussions of Pinto (2015), Baeninger et al. (2016) and Evangelista (2016) who studied Haitian immigration to the South American continent under different prisms as economic, demographic, sociologic, historic, political, legal and cultural approaches; whose authors are excellent references and extra sources of consultation to those interested in the theme.

As a result of primary data exploratory research, we perceived a larger agency of five Platine countries governmental institutions in attempt to understand this new immigrant context - bi and multilateral action issues as well as regional forums about Haitian immigration (Mercosur, 2012; Annoni; Manzi, 2016).

Literature consulted does not indicate a consensus about several issues in contemporary Haitian immigration, named as Haitian diaspora (Handerson, 2015) by some authors; however, we will discover for the main motivations and repercussions on interesting and challenging - in formulating agendas and public and territorial policies- contemporary immigratory flow.

Miranda and Junqueira (2015) argue that the political, economic and institutional situation in Haiti in the mid-2000s, after the decades of dictatorships of Jean-Claude Duvalier (Baby Doc) and Jean-Bertrand Aristide - with seemingly democratic "interregnums" - were conducive to a national instability nonpermissive to the full development of its inhabitants, be it educational, social, financial or cultural dimensions.

In the context of civil war that hit Haiti until 2004 and the subsequent installation of the United Nations Stabilization Mission in Haiti (UNSTAMIH) from June 2004 to April 2017, the population of that country was, for a decade, restricted to a territorial and political context with no chance of improvement or stabilization, although it presents satisfactory rates - for Caribbean standards from basic to higher education and professional qualification.

Since UNSTAMIH installation in 2004 under Brazil mandate - a capillarization of Lula's active and haughty external policy - until 2010 Haiti has experienced a period of national reconstruction: roads and streets, institutions, universities and country's own democracy (the first post-coup presidential election occurred in 2006).

That relative stability and reconstruction - although slow and bureaucratic - of the Haitian state was interrupted in the afternoon of January 12, 2010 with the 
greatest earthquake that has ever happened in Haitian history, reaching 7.0 Richter scale, whose epicenter was $25 \mathrm{~km}$ from the capital Port-au-Prince.

At the time of earthquake, the country was totally destroyed, killing about 316 thousand people and displacing another 1.5 million, more than $10 \%$ of the country's total population. In addition to the deaths of thousands of civilians and military members of UNSTAMIH, the earthquake killed Hedi Annabi, chief of the United Nations operation, as well as the Brazilian doctor Zilda Arns, international coordinator of Pastoral da Criança, and potential candidate for the award of the Nobel Peace Prize, causing great international commotion at the time.

This is a brief historical and contextual profile of Haiti, in order to have a starting point for the understanding of this migratory phenomenon destined to the so-called "Global South", because, until then, Haitian migrations were driven mainly to four countries: the Dominican Republic, the United States, Canada and France, and even less to Belgium and Cuba.

Why migrate to Brazil? This was the main question raised after the mass arrival of Haitians in the country since 2012. Scholars, governments and activists were not able to give a consensual explanation. Even consideringtroubled and unclear motivations, the choice for Brazil raises further questions. In the scope of reasons that led the Haitians to emigrate - namely still without country choice when in decision-making process - Mejía and Simon (2015) found the following responses: the need for immediate employment; leaving a completely destroyed country with no prospect; seek a better opportunity for their family; fear of another natural disaster (there was still the Hurricane Matthew in October 2016); political persecution; performance of Brazilian armed forces was a good "propaganda" and attractiveness; etc.

Such motivations caused disorientation in researchers when first analyzing the Haitian immigration (still in 2010 and 2012), and had a even greater effect on these groups reception in Brazil (among 2012 and 2014) and other Platine countries from 2015. What was the classification of Haitians immigrants? Refugees, economic immigrants, asylum seekers, irregular immigrants?

Literature and even legal order find difficulties to define those immigrants since they come from a country plagued by natural disasters (environmental refugees), political disasters (asylum or political refugees), and economic disasters (economic 
migrants). A solution pointed by Dilma Rousseff's administration (subsequently replicated by Argentina and Uruguay) was granting a humanitarian visa - a legal and consular apparatus between refugee status and regular immigration, with subsequent authorization to Haitians to remain in Brazilian territory.

To illustrate Haitian immigration in the Platine context we present the main routes used by Haitians heading towards Brazil and to other La Plata Basin countries with the following map (Figure 4).

It can be seen from the previous map that the routes used practically the entire South American territory, not to mention in this cartography, other routes used by Haitians in the North of the continent, through Venezuela and the three Guianas, entering Brazil by the states of Amazonas, Roraima, Pará and Amapá, but in a much lower degree and intensity (Handerson, 2015).

Bolivia, despite restrictions on the entry of Haitians, which is reflected in the country's refusal to provide statistical data on this migration, as well as Paraguay and Uruguay, served as transit countries before the arrival at the destinations in Argentina and Brazil.

However, according to Table 2, transitionally also includes the fixation of Haitians in these countries, especially after the aggravation of 2015 Brazilian crisis:

\section{Table 2}

Haitian immigratory flow in the Plata Basin countries - 2010/2016.

\begin{tabular}{lcccccccc}
\hline \multicolumn{7}{c}{ Haitian } \\
\hline Country/Year & 2010 & 2011 & 2012 & 2013 & 2014 & 2015 & 2016 & Total \\
\hline Argentina & 86 & 187 & 206 & 162 & 282 & 329 & 366 & 1,618 \\
Bolivia & 673 & 232 & 214 & 354 & 105 & 146 & 100 & 1,824 \\
Brazil & 111 & 480 & 4,281 & 5,611 & 10,691 & 14,533 & 20,626 & 56,333 \\
Paraguay & 37 & 46 & 37 & 38 & 84 & 106 & 88 & 436 \\
Uruguay & 38 & 32 & 91 & 97 & 85 & 89 & 84 & 516 \\
\hline
\end{tabular}

Source: compiled data by author from Ibid. 


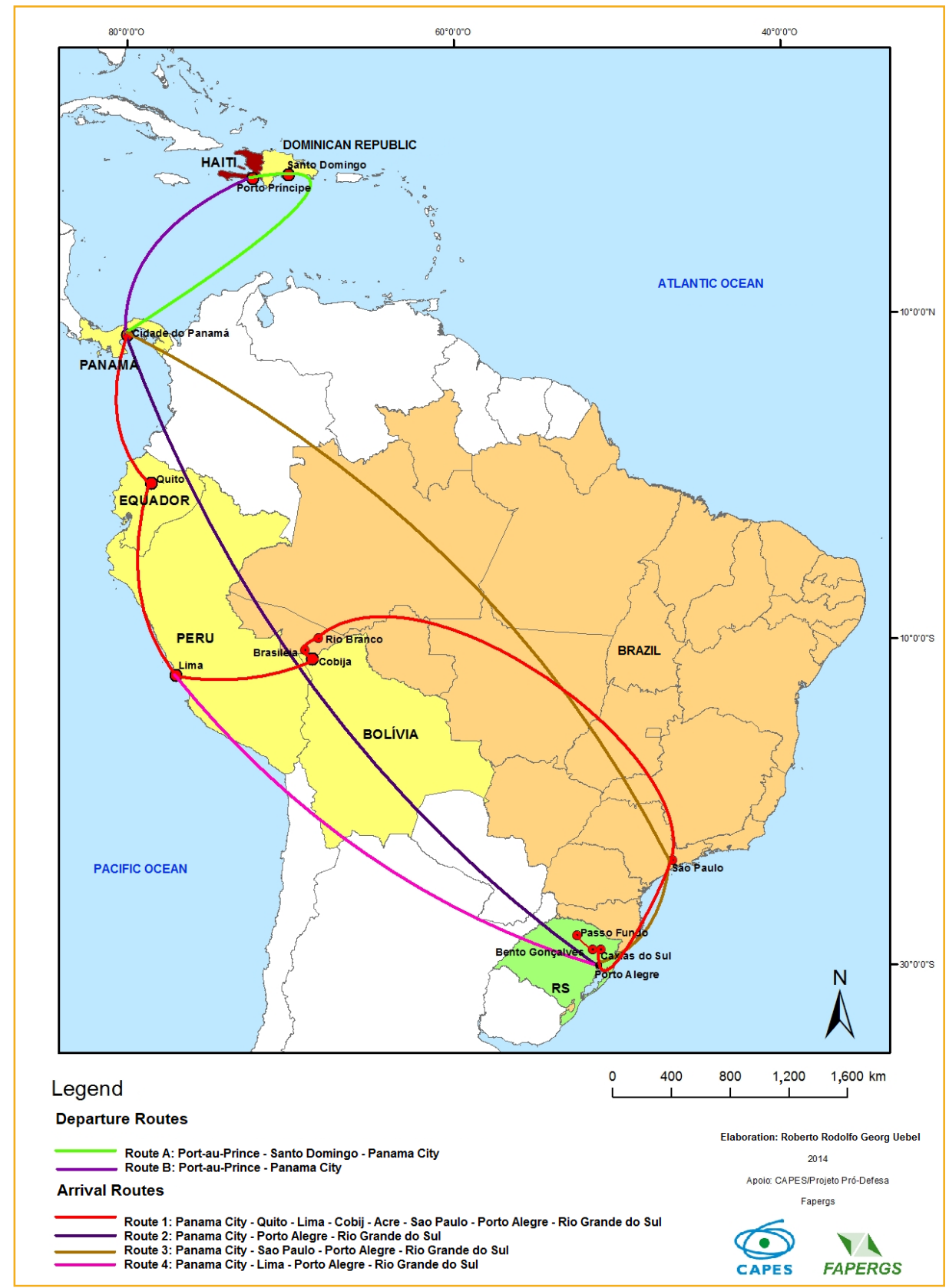

Figure 4. Map of the routes used by Haitians heading towards Latin America/La Plata Basin. Source: Author 
The land borders between Brazil/Uruguay/Argentina and between Paraguay/ Bolivia and Paraguay/Bolivia/Brazil were re-signified with the arrival in large contingents of almost 60,000 Haitians in the analyzed period, although Brazil is still the main country of destination.

Official information indicates that Bolivia has received about 1,824 Haitian immigrants between 2010 and 2016, but with only 29 permanent residence permits at the period, which characterizes the country as a transitory alternative destination, given its existing socioeconomic conditions, which are slightly superior and attractive considering those of Haiti itself, the sending country.

Furthermore, Argentina was the third country with the largest number of Haitian immigrants, many of these remigrants from Brazil after the beginning of 2014 crisis, reaching a contingent of almost 2,000 immigrants living in Greater Buenos Aires - which did not prevent episodes of xenophobia, for example (Lavaca, 2010).

Uruguay and Paraguay together received nearly 1,000 Haitians, mostly from the Brazilian states of Rio Grande do Sul and Santa Catarina, since they had been fired after the closure of industries in those regions; in those countries, Haitians are divided into two groups: a) those who seek new employment opportunities and attempt to stay; and b) those who are applying for asylum, refuge or immigrant visa at the US and Canadian embassies in Montevideo and Asunción.

In border regions, there were very interesting Haitians transnational praxis, such as religious, cultural and social traditions adapted from its origin, Haiti, with a dressingfrom the places where they initially settled in Brazil, such as the habit of drinking chimarrão; it is common to see in Rivera’s (Uruguay), La Plata's (Argentina) or Asuncion's (Paraguay) streets, Haitians-gauchos, who have knowledge of the Portuguese language and tell stories lived in Brazil, now replicated in their Platine neighbors.

We also identified another dynamics emerged after Haitian migratory influx: the creation of common agendas and working groups among La Plata Basin countries, made up of armed and police forces, diplomats, universities, business associations and NGOs from five countries, in order to create a regional "semipolicy" in attention to Haitians, as noted by Giraldi (2013).

Although it is not one of the main migrations in La Plata Basin - the internal Mercosureans are still the main ones, followed by Portuguese, Spanish and North 
Americans! - Haitian migration has boosted the borders, governments and societies of the countries to they migrated, seeking a reconstruction and restructuring, finding, however, scenarios opposite to their dreams and imagination, most of the time; and thus, demanding their own territorial reorganization and emergence of governmental adjustments.

\section{SENEGALESE IMMIGRATION IN LA PLATA BASIN}

If Haitian immigration in La Plata Basin was characterized by its intensity and transnational practices, we will see that Senegalese immigration, although numerically irrelevant - about 7,500 immigrants between 2010 and 2016 - has a highlight in its visibility and territorial repercussions that will be analyzed at this section.

Senegal is located on the west coast of the African continent (3,000 kilometers from the westernmost point of South America), and up to 7,000 kilometers from regions to which they migrated, separated by the giant Atlantic Ocean - historically linked by European colonialism, slavery and African-born cultures and religions that have won many supporters and admirers in the five Platine countries.

With a Human Development Index of 0.494 (considered underdeveloped) and a Gini coefficient of 40.3 (considered medium), Senegal is one of the most multicultural, multiethnic and multi-religious nations in Africa, owning twelve national languages, among them French, a French colonialism remnant.

Despite indicators, Senegal is one of the most democratic states in Africa and, according to Freedom House (2012), the country never had a coup d'état in its history (a constant event in continent's politics with dictatorial regimes existing until today, as in Zimbabwe, for example).

A stable democratic environment and a developing economy, even low, would theoretically provide fertile ground for country growth, its labor market and its institutions; but this is not the Senegal case.

Senegalese immigration has been intensified since 1960s towards Canada, France, Belgium and Italy, with its citizens migrating searching for better employment, education, social security and income opportunities. Predominantly Muslim religious, they did not find difficult to migrate towards other Muslim countries, 
such as Morocco - a route point between Senegal and La Plata Basin - as well as Arab nations from Southeast Asia and Russia (Mateso, 2016).

Historiography stands out that Senegalese migration can be divided into different stages or "waves", since Senegalese national state formation in 1960, but also before this existence, through forced slaves' migration according to Santos (2010).

It is not an erroneous claim, therefore, that Argentinean, Brazilian, Uruguayan and Paraguayan societies possess in their genetic, ethnic and historical-cultural DNA Senegalese traits and genes. That is a long discussion that we will not approach, it is only a reminder of the origins of these Platine states - often placed in a purposive and political-racial manner as "European-South American" countries, fertilizing separatist sentiments in interim of their transnational borders.

Senegalese immigration can be defined as a mobility of opportunities, a term we coined after reading Heredia (2015) and Tedesco and Kleidermacher (2017), differently from Haitian immigration - fueled basically by catastrophic political, economic and environmental factors. Although the statistical records of Argentina and Brazil, mainly, carry requests for refuge and political asylum on the part of the Senegalese, it can be affirmed with precision that all migrants of this new generation post-2014 have exclusively economic motivation.

However, La Plata Basin was not first the alternative for this group, taking into account long distances between origin and destination point, as well as high transportation and accommodation costs during the migratory transit, always carried out by air between the continents, and air and land in South America interior, as shown in map of Figure 5.

As it was seen in the previous map, South America and La Plata Basin (more specifically) were not destinations that appeared at the top of the Senegalese's priorities to emigrate. On the contrary, very little was known about these countries except its tradition in football, soap operas and the holding of 2014 FIFA World Cup in Brazil. It was precisely this sporting event and image created by soap operas what placed Brazil and Argentina on the route of contemporary Senegalese immigration.

With increasingly restrictive migration and border control policies in the European Union, that faces Sudanese, Somalis and Libyans mass flows, besides quotas imposed annually by Canada, Senegalese have been inserted into a paradox already studied by Rocha-Trindade (1995): where to migrate? 


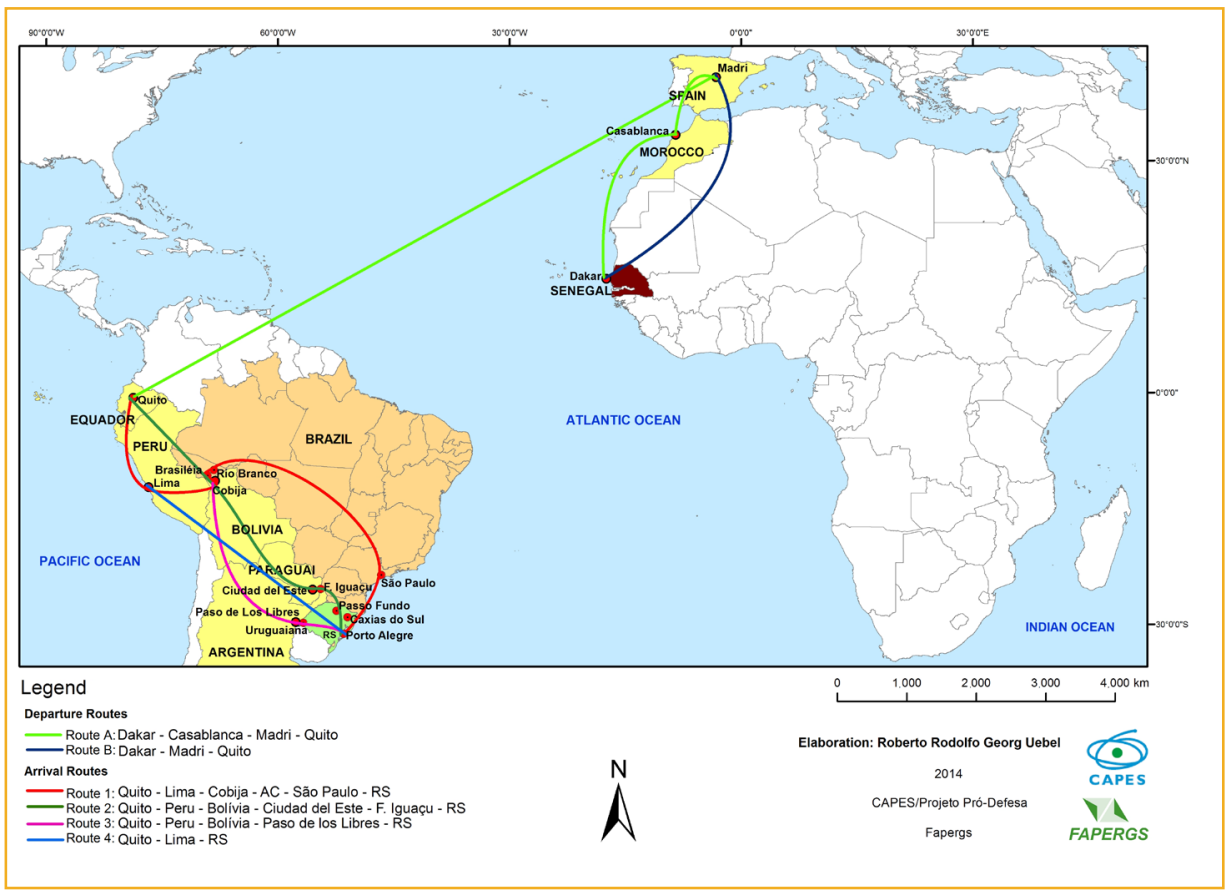

Figure 4. Map of the route used by Senegalese immigrants heading towards South America/La Plata Basin.

Source: compiled by the author.

However, South American scenarios seemed to converge with Senegalese's yearnings for a market to their goods and a job for their professional skills - Uebel (2015) has identified that most of them have a college degree and proficiency in at least two languages - 2014 Football World Cup in Brazil seemed to be the great opportunity to regularly migrate - albeit temporarily - to the South American giant.

As a policy of Dilma Rousseff's government to facilitate tourists' entry at the 2013 Confederations Cup, visa exemption for all nationalities was a facilitating point in decision to migrate to an alternative beyond the European Union and Canada. Argentina, in the same way, also facilitated the transit of tourists: why not extend the tour from Rio de Janeiro to Bariloche?

Such visa-free policies were in fact decisive for a great influx of not only Senegalese but also Ghanaians, who did not travel exclusively to accompany their football teams but also to risk a new life in countries they considered safe, stable and receptive, a thought that proved to be a mistake years later. 
Table 3 translates these quotas into:

Table 3

Senegalese Immigrant flow in La Plata Basin countries -2010/2016.

\begin{tabular}{lllllllll}
\hline \multicolumn{7}{c}{ Senegalese } \\
Country/Year & $\mathbf{2 0 1 0}$ & $\mathbf{2 0 1 1}$ & $\mathbf{2 0 1 2}$ & $\mathbf{2 0 1 3}$ & $\mathbf{2 0 1 4}$ & $\mathbf{2 0 1 5}$ & $\mathbf{2 0 1 6}$ & Total \\
Argentina & 25 & 9 & 4 & 1,579 & 1,497 & 1,170 & 1,191 & 5,475 \\
Bolivia & 0 & 86 & 447 & 27 & 101 & 18 & 21 & 700 \\
Brazil & 23 & 14 & 30 & 25 & 349 & 409 & 190 & 1,040 \\
Paraguay & 4 & 2 & 3 & 15 & 6 & 12 & 39 & 81 \\
Uruguay & 15 & 5 & 28 & 20 & 68 & 35 & 27 & 198 \\
\hline
\end{tabular}

Source: Data compiled by author from Ibid.

Contrary to media coverage given by the Brazilian press, which reached the point of announcing daily arrivals of Senegalese people in the bus stations of the state of Rio Grande do Sul (Correio do Povo, 2015), it was not Brazil that received the highest number of immigrants, but Argentina - almost 5 thousand individuals and their families in six years, five times more than their neighbors.

Furthermore, these numbers demystify another consensus issue among Brazilian researchers: new Senegalese immigration was first driven to Bolivia in 2012, later to Argentina in 2013. Only in 2014 Brazil begin to register a large migration boom. Not just intriguing but equally revealing, such numbers were obtained from official organs of Platine countries.

Paraguay and its 81 Senegalese in six years is irrelevant in numerical question, only a transit territory among great migratory dynamics of Bolivia/Argentina/ Brazil; Uruguay is not prominent - because it has received Senegalese remigrants both from Brazil and Argentina in recent years, or those who have not achieved refugee status in both countries.

In addition, when temporary visas granted by Buenos Aires and Brasília were overdue, many Senegalese had their regular condition turned into irregularity, deportations and loss of their jobs, which led to two movements: a) the request for refuge, denied almost immediately, because there is no evidence of serious violations of human rights in Senegal, as well as political persecution; b) permanent residence request or remigration between Brazil, Argentina and Bolivia, increasing tourist visas terms, thus their permanence conditions. 
As numbers show, this strategy did not work in Bolivia, with somewhat restrictive migratory policies, coupled with an unattractive or permissive scenario for Senegalese stay in Santa Cruz de La Sierra and La Paz regions; however, in Argentina a national policy (at the end of populist Cristina Kirchner's government) allowed its regularization and state attention.

With the worsening of the crisis in Brazil, about $80 \%$ of Senegalese formal employees were dismissed, thus adding a large contingent of informal workers, selling goods from smuggling - see the transnational and transbordering relations of the logic of migrant capital - on the streets of the big cities of South and Southeastern Brazil, as well as on the coast of great part of the country, from Rio Grande to Guarujá.

In this sense, Brazil saw a drastic reduction in Senegalese immigration between 2015 and 2016, unlike Argentina, which has had a steady flow since the 2013 boom, with no downward trends. This transformation is noticeable in the borders of the two countries, especially in Uruguaiana/Paso de Los Libres and Foz do Iguaçu/Puerto Iguazú, if before the flow was from Argentina to Brazil, now it is the opposite, with different expectations as well.

This re-dynamization of Senegalese immigration is a unique event in Platine history: a fast, intense, flashy (at least on the part of media) flow and constantly changing in a short time, (less than a decade).

At the end of this chapter, we also highlight the perverse part of this immigration, pointed by so many nuances and territorial dynamics: xenophobia, walls and barriers construction, and the hatred and aversion found by these migrants in the five La Plata Basin countries discourses, and the inexistence of pari passu policies like the Haitian ones by government bodies.

Valluy $(2008,2016)$ places this as a political choice inserted in a governmental xenophobia context. However, intercontinental territory and intra-regional flows have experienced a rich facet of Afro-American cultural dynamism, as well as equally rich experiences for small communities that welcomed these immigrants, contrasting aforementioned perversities. This is an intrinsic and core character of Migrations Geography, as described by Mabogunje (1970). 


\section{BORDERS, POLITICAL, ECONOMIC AND SOCIAL CHANGES}

In the two previous sections we have seen that the migrations of Haitians and Senegalese to La Plata Basin included several new dynamics and the reconfiguration of borders, policies and state actions. While on the one hand they have been positive about the modernization of these processes, we will now see that the political, economic, and social changes that occurred throughout the decade in our five countries have brought negative repercussions, such as xenophobic and separatist discourses, or revived nationalism, regionalism and regional anti-integration sentiments.

Not only the Platine countries, but also practically all Latin America, with exception of Venezuela, lived a decade of great economic, social, political and democratic advances (in Brazil, until the 2016 democratic breakdown). Latin Americans have never traveled, consumed, studied, and learned so much, despite all the socio-economic inequalities that still exist.

Even information access, means of consumption and the products of globalization (Santos, 2008) have been increasing, we are not able to affirm, however, that moral and ethical progress has coincided - especially regarding global humanitarian issues.

Although diverse ethnic groups, cultures, constitute Argentina, Bolivia, Brazil, Uruguay and Paraguay, nationalist and separatist sentiments have grown vigorously in the last decade, precisely due to an easier and increased access to information.

Regarding separatism itself, there are elements in different stages of structuring, especially in southern Brazil, as well as in Santa Cruz department in Bolivia, and Wallmapu Mapuche in Argentina, all with different motivations, but a common ideal: the separataion of the state.

Within separatist discourses, it is possible to find issues primarily linked to borders and, in a lesser extent, to migrations. Such movements would not be possible without border and territorial limits insertion in their speeches - although there is no unanimity on demarcations and border controls in the three groups mentioned. If we ask a member of Sulé meu pais (Brazil), Juvenile Cruceñista Union (Bolivia) or Consejo de Todas las Tierras (Argentina/Chile), surely they would not be able to say what imagined, official and possible State borders are.

Furthermore, people mobility (and migration) is a taboo subject for planners and urbanists of separatist movements. After all, a state needs individuals to 
exist, as Hobbes, Locke and Rousseau taught us. But what is the desirable kind of people to enter these States? Their former countrymen? European, indigenous, African immigrants? There is no answer, or at least, it is not registered in separatist movements, precisely because an idealized response would compromise the proper adhesion of new members to such movements: governmental xenophobia.

However, we do not need an intra-state separatist apparatus to identify actors and movements with aversion to immigrants' discourses - or foreign, illegal, clandestine - in La Plata Basin context, many politicians, from local to senators, were in charge of uttering words against Haitians, Senegalese, Syrians and Venezuelans.

In the Brazilian case, we have seen a flood of xenophobic actions and speeches in recent years, starting with a city councilman from the Brazilian city of Caxias do $\mathrm{Sul}$ - that received small groups of Senegalese and Haitians - as follows:

I did not like these guys coming here. They are bringing no benefits to Brazil at all. They came to bring more poverty. So I'm not in favor of these guys here, not at all. People here need a lot of support too and they do not have it. (G1 RS, 2014).

However, the xenophobic discourse was not restricted to city councilmen. Republic senators such as Romero Jucá, one of leaders of the government of Michel Temer in Brazilian Senate, emphatically expressed that Brazil should not welcome Venezuelan refugees, and presented some ignorance about country migratory reality:

I defended and continue to defend denial of refuge requests [...] Refuge is okay to Haiti people, where there was an earthquake, calamity and the plague has raged, or because of war like Libya, people are killing each other there, bursting bombs on boys' heads, this is a problem for refuge, [in Venezuela] it's a matter of dictatorship, of political quarrel, so I defend that requests are not approved. [...] It is very easy for Maduro to send five million people to Brazil because we are going to pay the bill here and he gets rid of the problem.(Mello, 2017).

Furthermore, political discourse-which found similar xenophobic reverberations in Argentina during the review of immigration legislation by the government of Mauricio Macri (Page 12, 2017) - media has also presented a contrary view to 
migrations, as can be seen in the headline of one of the main Brazilian monthly magazines: "Brazilian growth absorbs Haiti's poor, for now" (Revista Veja, 2012).

Another mechanism that has been potent in the publication of opinions and demonstration of aversion to new immigrants in La Plata Basin is social networks, which have no boundaries and are precisely influenced by political, economic and social changes of the region in the last two decades.

If in the 1820 s a newspaper took a month to register a fact involving the arrival of a family of German, Italian or Spanish immigrants - when it registered - in the ports of Buenos Aires, Montevideo or São Leopoldo, at present the arrival of a Haitian in the bus station of Porto Alegre or a Senegalese couple in Buenos Aires' Buquebus is immediately published not only by the online pages of the newspapers, but they are also photographed and "denounced" on Twitter, Instagram and Facebook before they even reach their shelters or homes.

What motivations lead to mediatization and resumption of "foreigner" aversion in nations that have been rightly built by European, African, Asian, and indigenous energy and labour?

Cordova (2017) responds that a re-signification of nationalism, faced with globalization imposition as a way of life and production in late 1980s, allied with Latin America redemocratization and events of "world disintegration" such as Brexit, populist Trump's conservatism, Le Pen et al., and the resurgence - as if they had ever disappeared - of white, Nazi, nationalist, ultra-rightist, and ultra-leftist supremacist ideologies were a lever for these aversion and hatred discourses, both in social networks as in real life.

The dynamization of the world, political freedom, re-signification of territories role, and expansion of information access, unfiltered and unchecked, have often allowed everybody to expose their opinions, dreams and desires in an aggressive, immediate, amoral and, in particular, anti-democratic way as in many reported cases.

Staudt (2017) argues that this is perhaps the way of a redefinition of the planet, of the nations and their borders, in stark contrast to what had been planned by a set of nations at the end of the Cold War. This new rationality, therefore, would allow descendants of immigrants to freely express their discontent and aversion to immigration to their cities, states and countries, without any remorse or feeling of 
obligation towards other immigrants, since everything had been reconfigured or "deconstructed."

We cannot say whether this will be the standard of humankind, whether in the confines of Mongolia or the triple Brazil-Paraguay-Argentina border, or in the Mediterranean bloodied by humanitarian wrecks and tragedies, but we can say that political, economic and social relations will increasingly influence borders and migrations themselves, placing the "I" in front of the "other", thus reversing a millenarian quasi-natural logic pointed out by Harari (2014).

The fear of Ebola, terrorism, unemployment, and criminality allegedly brought ${ }^{5}$ by migration will give way to the true expression and sentiment of each individual - or groups of individuals - however much of this confronts the Republican, democratic, Christian and western ideals and discourses of Platine countries.

\section{FINAL CONSIDERATIONS}

Throughout this chapter we enumerate the quantitative immigration for the five countries that make up La Plata Basin, namely, Argentina, Bolivia, Brazil, Paraguay and Uruguay; five states formed by a Spanish-Portuguese colonization of their native nations - from Tupi, Guarani to Incas -, forced migration of African slaves and economic migrations and refuges of Europeans, Arabs, Asians and even other Latin American peoples.

Despite the multicultural character of the Platine societies, recent immigration, called "new groups", such as Senegalese, Haitian, Bengalis and Malaysians, in addition to the Syrian refugees, were treated differently by the receiving societies, as well as by the public policies of Buenos Aires, Brasília, La Paz, Asunción and Montevideo.

Not only did the cultural-legal scope perceive transformations from new influxes

\footnotetext{
5 About migration issues: "Ebola: imigrantes negros são discriminados depois de caso suspeito em Cascavel" <http://agenciabrasil.ebc.com.br/direitos-humanos/noticia/2014-10/ebola-imigrantesnegros-sao-discriminados-no-brasil-depois-de-caso>; "Refugiado sírio é atacado em Copacabana: 'Saia do meu país!”’https://oglobo.globo.com/rio/refugiado-sirio-atacado-em-copacabana-saiado-meu-pais-21665327>;"Bolsonaro chama refugiados de "escória do mundo"<http://exame.abril. com.br/brasil/bolsonaro-chama-refugiados-de-escoria-do-mundo/>; "Imigrantes Haitianos sofrem racismo e xenofobia no Brasil” <https://www.terra.com.br/noticias/brasil/imigrantes-Haitianossofrem-racismo-e-xen ofobia-no-brasil,a55e260ac95f5410VgnVCM1 0000098 cceb0aRCRD. html>.
} 
or new migratory dressing, but also the territory of the Platine countries perceived a deep reconfiguration of national borders and regional transbordering spaces. Platine land borders gained a new economic, institutional, political and military role in relation to the migration boom of the twenty-first century.

Numbers of immigration flows, obtained from official bodies of the five countries studied indicated several subjectivities, hitherto held by common sense and even by academy as exposed untruths or counter-truths. For example, we identified that Brazil received less immigrants than Paraguay and Argentina between 2010 and 2016, while Bolivia was the second country with the largest immigration of Haitians, and Argentina with the largest Senegalese influx.

But these final considerations are not restricted to numerical quantitative of immigration, because it is known that Platine America was and will always be a destination of great migrations, depending on the cycles intrinsic to them and the proper dynamization of globalization and interstate and multi-societal capitalism.

However, the attention is focused directly on globalization dynamism and its repercussions on regional praxis in La Plata Basin, such as the rise of separatist movements, anti-immigration, governmental and contestatory xenophobia, nationalism and supremacist regionalism. These issues, linked by a guiding thread to migration themes and borders, are the real focus of demographers, geographers, internationalists and political scientists, who deserve equal attention from public agents.

La Plata Basin, according to our understanding from reading migratory and territorial dynamics, in a short period of time, presents a giant economic and structural potential within the scope of the "Global South" and South-South relations, movements either dormant or restricted to small groups, under the influence of their peers in the "North", may threaten regional integration programs, interstate and intra-regional territorial planning, as well as remove the already built character of welcoming migrants and refugees - despite all deficiencies - as an alternative model to great powers that, facing crises nowadays, originate precisely from these nascent feelings in the interim of their societies.

The Platine borders reconfiguration and re-signification can serve as a basis for a new understanding and clarification of recent immigration, especially within the civil society and press, in order to avoid such sentiments and to further promote 
the potentialities of the five Platine countries, drivers of a whole regional, cultural, political and historically contestatory development. It is not a matter of rewriting history from new migrations, but of rewriting perception of migrations from history and its lessons.

\section{REFERENCES}

Amorim, C. (2015). Teerã, Ramalá e Doha: memórias da política externa ativa e altiva. São Paulo: Benvirá. 520 p.

Annoni, D. and Manzi, M.J.L. (2016). Política migratória brasileira e seus reflexos para os estados da UNASUL: um estudo a partir do tratamento dado pelo Brasil ao caso dos Haitianos. Boletín Mexicano de Derecho Comparado, Mexico, 49(146), p. 6183, ago. 2016. Retrieved from: <http://www.scielo.org.mx/scielo.php?pid=S0041863320160002000618 script=sci_arttext>.

Argentina. Dirección Nacional de Migraciones (2016). Panorama Movimientos Migratorios.Retrieved from: <http://www.migraciones.gov.ar/pdf_varios/estadisticas/ panorama_mov_migratorios_2016.pdf $>$.

Arocena, F. and Aguiar, S. (2007). Multiculturalismo en Uruguay: ensayo y entrevistas a once comunidades culturales. Montevideo: Ediciones Trilce. 230 p.

Baeninger, R. (2015). Migraçôes contemporâneas no Brasil: desafios para as políticas sociais, In: Prado, E. J.P. and Coelho R. (ed.). Migraçôes e trabalho. Brasília: Ministério Público do Trabalho, 2015, p. 79-86. Retrieved from: <https://portal.mpt.mp.br/wps/wcm/ connect/portal_mpt/2744ae77-4584-4d92-b91d-185adc09ba87/Livro_Migracoes_e_ TrabalhoWEB.pdf?MOD=AJPERES\&CONVERT_TO=url\&CACHEID=2744ae774584-4d92-b91d-185adc09ba87>.

Baeninger, R. et al (2016). Imigração Haitiana no Brasil. Jundiaí: Paco Editorial. 684 p.

Bèle, P. (2012) Coup d'état express au Paraguay. Retrieved from: <http://blog.lefigaro.fr/ amerique-latine/2012/06/coup-dtat-express-au-paraguay.html>. Acesso em: 21 ago. 2017.

Bengochea, J. (2014). Inmigración reciente en Uruguay: 2005 - 2011. Curso de Demografía y Estudios de Población, Facultad de Ciencias Sociales, Universidad de La República, Retrieved from: <https://www.colibri.udelar.edu.uy/bitstream/123456789/8151/1/TUM_ BengocheaJulieta.pdf $>$.

Berry, D. P. and M.P. Bell (2011). 'Expatriates': Gender, Race and Class Distinctions in International Management. Gender, Work \& Organization, 19(1), p. 10-28. Retrieved from: <http://onlinelibrary.wiley.com/doi/10.1111/j.1468-0432.2011.00577.x/full>. 
Brasil. (1970). Decreto $n^{\circ}$ 67084, de 19 de agosto de 1970. Promulga o Tratado da Bacia do Prata. Brasília, Retrieved from: <http://www.planalto.gov.br/ccivil_03/decreto/1970-1979/ anexo/and6708470.pdf>.

Caggiano, S. (2003). Fronteras múltiples: Reconfiguración de ejes identitarios en migraciones contemporáneas a la Argentina. Cuadernos del IDES 1, p. 3-24, set. 2003. Retrieved from: <http://repositorio.umsa.bo/bitstream/handle/123456789/1436/ L001010.pdf? sequence $=1$ \& risAllowed $=y>$.

Carneiro Fillho, C. P. (2016). Fronteiras irmãs: transfronteirizações na Bacia do Prata. Porto Alegre: Ideograf. 273 p.

Carrizo, G. (2009). Ruptura populista y política en América Latina: Bolivias en tiempos de Evo Morales. Nómadas 22, p. 1-17. Retrieved from: <http://www.redalyc.org/articulo. oa?id=18111430017>.

Castillo, J. and J. Gurrieri (2012). El panorama de las migraciones limítrofes y del Perú en la Argentina en el inicio del siglo XXI. Cuadernos Migratorios 2, p. 17-50. Retrieved from: <http://hdl.handle.net/20.500.11788/1434>.

Clarín (2017). Mauricio Macri firmó el decreto que modifica la Ley de Migraciones: los principales puntos. Retrieved from: <https://www.clarin.com/politica/mauricio-macrifirmo-decreto-modifica-ley-migraciones-principales-puntos_0_ByiU5 KnDg.html>.

Córdova, N. A. (2017). 'O melhor do Brasil é o brasileiro': como a 'Primeira Guerra Memeal' resgatou o sentimento de nacionalismo nas redes sociais brasileiras. Retrieved from: <http://www.repositorio.jesuita.org.br/handle/UNISINOS/6412>.

Correa, J. P. (2014). Mujica trae presos de Guantánamo y pide a Obama liberar espías cubanos.Retrieved from: <http://www.elpais.com.uy/informacion/mujica-trae-presosguantanamo-pide.html>.

Correia, A. (2016). Destinos insólitos para venezolanos: Paraguay. Retrieved from: <https:// www.revistavenezolana.com/2016/06/destinos-insolitos-venezolanos-paraguay/>.

Correio do Povo (2015). Quatro Haitianos e dois Senegaleses chegam a Porto Alegre. Retrieved from: <http://www.correiodopovo.com.br/Noticias/Geral/2015/5/557660/ Quatro-Haitianos-e-dois-Senegaleses-chegam-a-Porto-Alegre>.

Domenech, E. (2007). La agenda política sobre migraciones en América del sur: el caso de la Argentina. Revue Européenne des Migrations Internationales 23(1), p. 71-94. Retrieved from: <http://remi.revues.org/3611>.

Evangelista, I. D. (2016). Del Caribe Haitiano a la argentina:Trayectorias de cuerpos en movilidad humana pos terremoto 2010. Buenos Aires: CLACSO. 23 p. Retrieved from: <http://biblioteca.clacso.edu.ar/clacso/pobreza/20160307040904/Duffard.pdf>.

Fajnzylber, P. and J.H. Lopez (2008) Remittances and Development: Lessons from Latin America. Washington: World Bank Publications. 408 p.

Freedom House (2012). In Senegal, Years of Frustration Come to a Head. Retrieved from: <https://freedomhouse.org/blog/senegal-years-frustration-come-head>. 
G1 RS (2014). 'Vieram trazer mais pobreza', diz vereador sobre imigrantes no RS. Retrieved from: <http://g1.globo.com/rs/rio-grande-do-sul/noticia/2014/03/vieram-trazer-maispobreza-diz-vereador-sobre-imigrantes-no-rs.html>.

García, M. I. (2016). Bajo la óptica del Estado: Migrantes Senegaleses y procesos de visibilización en Argentina (2005-2015). 2016. Facultad de Filosofía y Letras, Universidad de Buenos Aires, Buenos Aires.Retrieved from: <http://repositorio.filo.uba.ar/handle/ filodigital/3268>.

Giralldi, R. (2013). Brasil e cinco países se reúnem para conter ação de coiotes com imigrantes Haitianos.Retrieved from: <http://www.ebc.com.br/noticias/brasil/2013/05/brasil-e-cincopaises-se-reunem-para-conter-acao-de-coiotes-com-imigrantes>.

Handerson, J. (2015). Diaspora: as dinâmicas da mobilidade haitiana no Brasil, no Suriname e na Guiana Francesa. Universidade Federal do Rio de Janeiro, Rio de Janeiro. Retrieved from: <https://drive.google.com/file/d/0B-o4vWm2nGXBR0FYNkJsbDF3ZFE/view>.

Harari, Y. N. (2014). Sapiens: a brief history of humankind. Londres: Harvill Secker. 443 p. Herédia, V. B. M. (Ed).(2015) Migraçôes Internacionais: O caso dos Senegaleses no Sul do Brasil. Caxias do Sul: Belas-Letras. 292 p.

INFOBAE (2006). Elogian al plan Patria Grande como ejemplo mundial. Retrieved from: <http://www.infobae.com/2006/11/11/285906-elogian-al-plan-patria-grande-comoejemplo-mundial/>.

Jinkings, I., Doria, K. and Cleto, M. (Ed). (2016) Por que gritamos golpe?: para entender o impeachment e a crise. São Paulo: Boitempo. 169 p.

LAVACA (2010). La discriminación en colectivo. Retrieved from: <https://www.lavaca.org/ notas/la-discriminacion-en-colectivo/>.

Lemos, B.O. and Rüickert, A. A. (2014). A Nova Agenda para Cooperação e Desenvolvimento Fronteiriço entre Brasil e Uruguai: repercussóes territoriais nas cidades - gêmeas de Sant'Ana do Livramento e Rivera. Política e Planejamento Regional 1(1). p. 38158. Retrieved from: <http://www.revistappr.com.br/artigos/publicados/A-Nova-Agendapara-Cooperacao-e-Desenvolvimento-Fronteirico-entre-Brasil-e-Uruguai.pdf>.

Mabogunje, A. L. (1970). Systems Approach to a Theory of Rural-Urban Migration. Geographical Analysis 2(1), p. 1-18. Retrieved from: <http://onlinelibrary.wiley.com/ doi/10.1111/j.1538-4632.1970.tb00140.x/epdf>.

Mamed, L. H. (2016). Imigração caribenha e africana pela fronteira trinacional Peru-BolíviaBrasil: características, especificidades e repercussão social. In: Migraçóes Internacionais, Refúgio e Políticas, São Paulo. Campinas: Nepo, p. 1-30. Retrieved from: <http://www.nepo. unicamp.br/publicacoes/anais/arquivos/38_LHM.pdf>. Acesso em: 19 ago. 2017.

Mármora, L. (2016). Impacto de las migraciones actuales en la estructura económica y socio cultural de la Argentina. Sáenz Peña: Eduntref. 380 p.

Mateso, M. (2016). La détresse des Sénégalais et Africains, devenus indésirables en Russie. Retrieved from: <http://www.leral.net/La-detresse-des-Senegalais-et-Africains-devenusindesirables-en-Russie_a173141.html>. 
Mejía, M. R. G. and Simon, R. (2015). Sonhos que mobilizam o imigrante Haitiano: biografia de Renel Simon. Lajeado: Univates. 72 p.

Mello, P. C. (2017). Romero Jucá propóe que Brasil negue refúgio a venezuelanos. Retrieved from: <http://www1.folha.uol.com.br/mundo/2017/08/1912652-romero-juca-propoeque-brasil-negue-refugio-a-venezuelanos.shtml>.

MERCOSUL (2012). Cooperação do Mercosul com o Haiti em direitos humanos. Retrieved from: <http://www.ippdh.mercosur.int/pt-br/cooperacao-do-mercosul-com-o-haiti-emdireitos-humanos/>.

Miranda, S. C. and Junqueirra, M.J.S. (2015). Haitianos no Brasil: compreendendo o movimento migratório a partir da cidade de Cajamar/SP. Ponto e Virgula, Sáo Paulo, 18, p.108-125. Retrieved from: <https://revistas.pucsp.br/index.php/pontoevirgula/article/ viewFile/29800/20717>.

Moreira, J. B. (2014). Direito Internacional dos Refugiados e a legislação brasileira. In: Ramina, L. and Friedrich, T.S. (Ed.) Coleção Direito Internacional Multifacetado - Volume III: Direitos Humanos, Guerra e Paz. Curitiba: Juruá. 101-130.

Morin, C. (2012). Paraguay - Un «coup d'État parlementaire». Retrieved from: <http:// www.ledevoir.com/international/actualites-internationales/354289/un-coup-d-etatparlementaire>.

Netto, A. and Chade, J. (2009). Imigrante sofre mais com desemprego.Retrieved from: <http://economia.estadao.com.br/noticias/geral,imigrante-sofre-mais-comdesemprego,346457>. Acesso em: 19 ago. 2017.

Oddone, H. et al (2011). Perfil Migratorio de Paraguay. Buenos Aires: OIM. 92 p. Retrieved from: <http://publications.iom.int/system/files/pdf/perfilmigratoriodeparaguay. $\mathrm{pdf}>$.

Oliveira, A. P. (2012). "Tenemos miedo de nosotros mismos": a construção social do medo em uma situação de conflito prolongado: os refugiados colombianos reassentados no Rio Grande do Sul. Retrieved from: <http://www.lume.ufrgs.br/handle/10183/102198>.

Organizaçáo dos Estados Americanos (OEA) (2015). Migración internacional en las Américas: Tercer informe del Sistema Continuo de Reportes sobre Migración Internacional en las Américas (SICREMI) Washington: OEA. 235 p. Retrieved from: <http://www. migracionoea.org/images/sicremi/SICREMI_SPANISH_web.pdf>.

Organizaçáo Internacional para as Migraçóes (OIM) (2012). Rutas y dinámicas migratorias entre los países de América Latina y el Caribe (ALC), y entre ALC y la Unión Europea. Bruxelas: OIM, 2012. 158 p. Disponível em: <http://publications.iom.int/ system/files/pdf/rutas_migratorias_final.pdf>.

Organizaçáo para a Cooperaçáo e Desenvolvimento Econômico (OECD) (2012). Latin America and the Caribbean: migration analysis, In: Organização para a Cooperação e Desenvolvimento Econômico. Connectingwith Emigrants: A Global ProfileofDiasporas. Paris: 
OCDE. 89-142. Retrieved from: <http://www.keepeek.com/Digital-Asset-Management/ oecd/social-issues-migration-health/connecting-with-emigrants_9789264177949en\#page9>.

Página 12. (2017). El muro de Macri para los migrantes. Retrieved from: <https://www. pagina12.com.ar/17060-el-muro-de-macri-para-los-migrantes>.

Pinto, J. M. S. (2015). Os deslocamentos forçados dos Haitianos e suas implicaçōes:um desafio global na sociedade de risco. Retrieved from: <http://www.repositorio.jesuita.org. br/handle/ UNISINOS/4927>.

Pintos, L. (2017). "Paraguay, tierra de oportunidades". Retrieved from: <http://www. lanacion.com.py/pais_edicion_impresa/2017/07/30/paraguay-tierra-de-oportunidades/>.

Piore, M. J. (1979). Birds of passage: migrant labor and industrial societies. Cambridge: Cambridge University Press. 229 p.

Pizarro, J. M. and Rivera, C.O. (2016) Nuevas tendencias y dinámicas migratorias en América Latina y el Caribe. Serie Población y Desarollo 114, p. 1-107. Retrieved from: $<$ http://repositorio.cepal.org/bitstream/handle/11362/39994/1/S1600176_es.pdf>.

Prado, M. L. and Pellegrino, G. (2014) História da América Latina. São Paulo: Contexto. $208 \mathrm{p}$.

Revista Veja (2012.) Crescimento brasileiro absorve pobres do Haiti, por enquanto. Retrieved from: <http://veja.abril.com.br/mundo/crescimento-brasileiro-absorve-pobresdo-haiti-por-enquanto/>.

Rocha-Trindade, M. B. (1995). Sociologia das Migraçôes. Lisboa: Universidade Aberta. 410 p.

Rückert, A. A.; Carneiro Filho, C. P. and Uebel, R.G. (2016). Transborderings in South America: Some Examples of Recent Researches. In: COLLOQUE INTERNATIONAL DU CIST, 3., Grenoble. Proceedings du 3e colloque international du CIST. Grenoble: Collège International Des Sciences Du Territoire, p. 421-428. Retrieved from: <https:// halshs.archives-ouvertes.fr/hal-01353683/document>.

Santos, C. M. (2010). O tráfico de escravos do Brasil para o rio da Prata. Brasília: Ediçóes do Senado Federal. 192 p.

Santos, M. (2008). Técnica, espaço, tempo:globalizaçăo e meio técnico-científicoinformacional. 5. ed. São Paulo: EDUSP. 174 p.

Silva, S. A. and Assis, G. O. (2016). Em Busca do Eldorado: O Brasil no Contexto das Migraçóes Nacionais e Internacionais. Manaus: Editora da Universidade Federal do Amazonas. 347 p.

Staudt, K. (2017). Border Politics in a Global Era:Comparative Perspectives. Lanham: Rowman \& Littlefield Publishers. 320 p.

Tedesco, J. C. and Kleidermacher, G. (Ed.). (2017). A imigração senegalesa no Brasil e na Argentina: múltiplos olhares. Porto Alegre: Est Ediçôes. 368 p. 
Uebel, R. R. G. (2015). Análise do perfil socioespacial das migraçóes internacionais para o Rio Grande do Sul no início do século XXI: redes, atores e cenários da imigração Haitiana e senegalesa. Retrieved from: <http://hdl.handle.net/10183/117357>.

Uebel, R. R. G. (2017). International Migrations to Brazil in the $21^{\text {st }}$ Century: Profile, Outlook and Trends. Population Review 56(1), p. 68-101, Retrieved from: <https://doi. org/10.1353/prv.2017.0003>.

Valluy, J. (2008). Du retournement de l'asile (1948-2008) à la xénophobie de gouvernement: construction d'un objet d'étude. Cultures \& Conflits 69, p. 81-111. Retrieved from: <http:// conflits.revues.org/10752>.

Valluy, J. (2016). The Metamorphosis of Asylum in Europe: From the Origins of "Fake Refugees" to their Internment. In: PALIDDA, Salvatore (Ed.). Racial Criminalization of Migrants in the $21^{\text {st }}$ Century. Nova York: Routledge. Cap. 7. 


\section{LA PLATA REGION TRIPOINTS: STATE OF THE MATTER AND DESCRIPTIVE COMPARISON}

\section{Alejandro Benedetti}

\section{ABSTRACT}

Where the Paraná and Iguazú rivers meet, the most important and studied trinational region of South America is located: the Triple Frontier. However, this is only one of the 13 tripartite points that were formed in that continental region from the process of interstate delimitation which occurred, centrally, between the late $19^{\text {th }}$ and early $20^{\text {th }}$ century. Five out of these involve the countries of La Plata Basin, and will be called: Quareim (Argentina-Brazil-Uruguay); Iguazú (Argentina-Brazil-Paraguay); Esmeralda (Argentina-Bolivia-Paraguay); Zapaleri (Argentina-Bolivia-Chile); and Bahía Negra (ArgentinaBolivia-Brazil). This article aims to offer a description of each of the five tripoints that the countries of the del Plata area share, that is, Argentina, Bolivia, Brazil, Paraguay and Uruguay. Besides, it seeks to establish some comparisons between its space-time dynamics. This article is part of a general investigation about South American interstate borders.

KEYWORDS South American interstate borders, space-time dynamics, La Plata region tripoints. 
At the confluence of Paraná and Iguazú rivers, the most studied transnational urban region of South America was formed, to the point that its geopolitical condition became its toponym: the Triple Frontier. There, a trilateral urban system was formed, composed by Puerto Iguazú-Foz do Iguaçu-Ciudad del Este, cities located, respectively, in Argentina, Brazil and Paraguay. However, this is no more than one of the 13 triple frontiers or, as this article will define them, tripoints ${ }^{1}$ that emerged in South America from the inter-state delimitation process which basically took place between the middle of the $19^{\text {th }}$ century and the beginning of the $20^{\text {th }}$ century. Five of these tripartite points are shared by the countries that make up La Plata region (Figure 1):

- Tripoint between Argentina, Brazil and Uruguay. It is located at the confluence of the Cuareim/Quaraí river (border between Brazil and Uruguay) with the Uruguay/Uruguay river (Argentina's border with the other two countries). It will be called trifold of Cuareim.

- Tripoint between Argentina, Brazil and Paraguay, already mentioned. It is located where the Iguazú/Iguaçu river (boundary between Argentina and Brazil) flows into the Paraná River (Paraguay's border with the other countries). It will be called tripoint of Iguazú.

- Tripoint between Argentina, Bolivia and Paraguay. It is known as - and so will be named - Esmeralda landmark. It is located near the current course of the Pilcomayo River (which serves as the boundary of Argentina with both countries).

- Tripoint between Argentina, Bolivia and Chile. It is located at the top of Cerro Zapaleri. From that landmark, the boundaries were drawn with straight lines in all three directions. There are no water courses in the hill itself, but it is close to the sources of the Pilcomayo River. It will be referred to as tripoint Zapaleri.

1 The Spanish word is: trifinio or punto tripartito. 


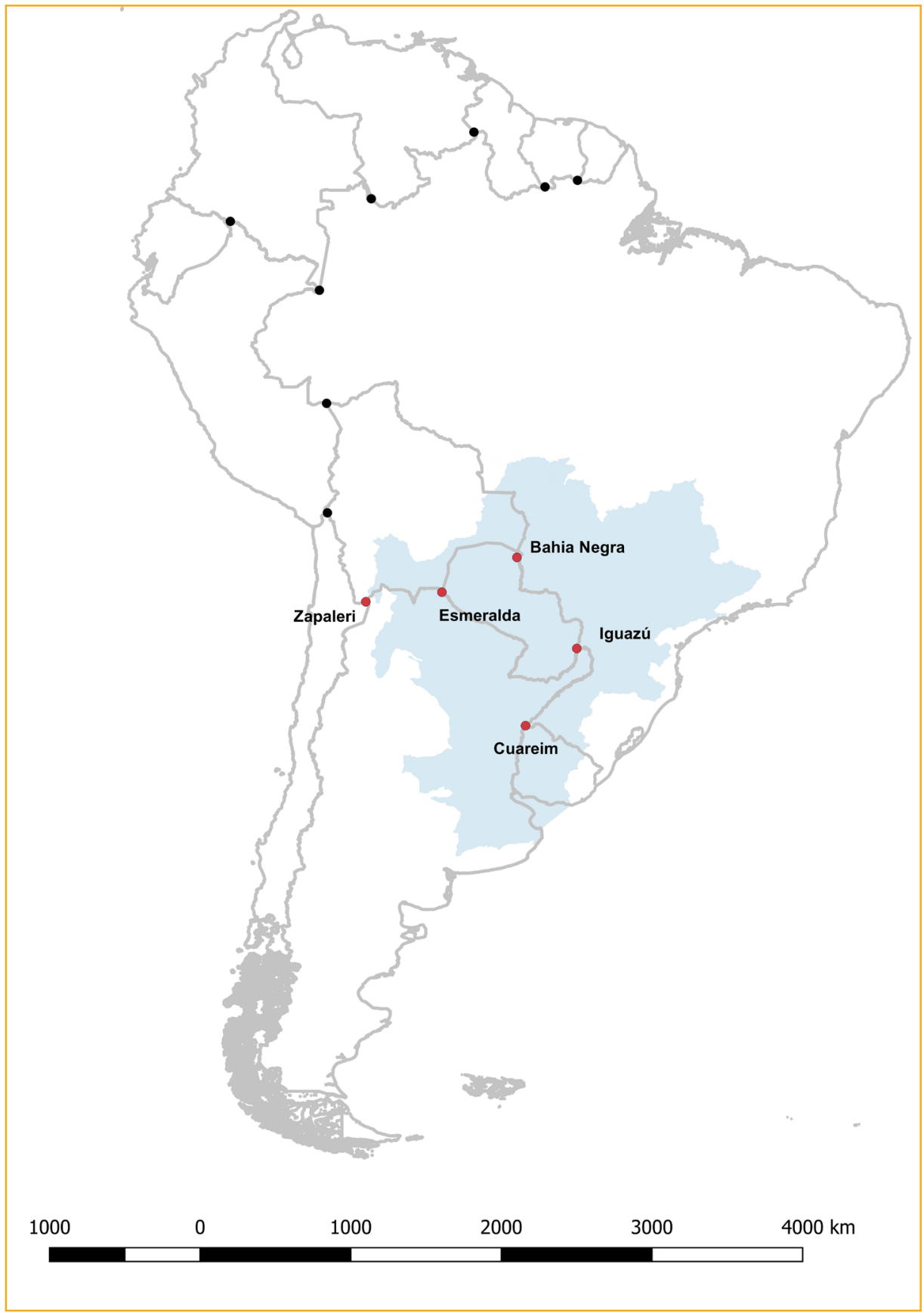

Figure I. South American tripoints, differentiating those that were formed between the countries of the del Plata region.

Source: author. 
- Tripoint between Bolivia, Brazil and Paraguay. It is found in the meeting of the Negro River (used, in part, for the Bolivia-Paraguay border) with the Paraguay/Paraguay river (which in some sections serves as the boundary of Brazil with both countries). This area is known as Bahía Negra, so this tripoint will be referred to with that name.

The degree of interest and knowledge production regarding these tripoints, from the field of border studies in particular and from social studies in general, is uneven. While the Iguazú tripoint has numerous academic articles and doctoral theses that consider it (directly or indirectly), the Esmeralda and Bahía Negra tripoints (as a reflection of the general lack of interest in the Bolivia-Paraguay border) are barely referenced. Likewise, the spatiotemporal dynamics that are registered in each of these trilateral areas are dissimilar among them: while the Cuareim and Iguazú tripoints are intensely urbanized, the remaining three are almost permanently depopulated. On the other hand, while the Esmeralda tripoint area was historically populated by hunting and gathering populations - conquered by the national states only towards the end of the $19^{\text {th }}$ century-, the site where the tripoint Zapaleri is currently found had already been controlled by the Spanish Crown.

This article sets out two objectives. The first is to provide a description of each of the five tripoints shared by the countries of the del Plata region, namely Argentina, Bolivia, Brazil, Paraguay and Uruguay. The second objective, which will be discussed first, is to establish some comparisons of their spatiotemporal dynamics. To do this, four axes of analysis will be considered: interstate relations and the delimitation processes that gave rise to them; existing urban centers and outgoing forms of territorial occupation; infrastructure and general forms of mobility of goods and people; notable sociocultural features (indigenous presence, immigrant minorities, etc.).

\section{THE STUDY OF SOUTH AMERICAN TRIPOINTS}

Tripoint designates the point where the ends of three jurisdictions or any other type of discrete geographic scope converge. An equivalent expression is a tripartite point. A derivation of this definition is the triple border. Whenever the boundary is considered to be equivalent to the linear expression of the division between two geographical areas, the threefold border will designate the point of union of three 
frontiers. However, in the use of this expression, the literature usually refers to the more or less articulated geographic area between three countries that is organized around a tripartite milestone.

When you google "triple border" in Google's academic search engine (https://

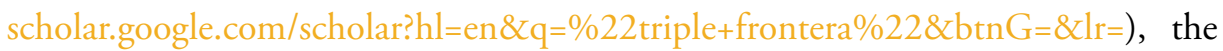
results show articles referring to the meeting area of the territories of Argentina, Brazil and Paraguay. Precisely, this area is known as "Triple Border". Some authors choose to name it as tri-national trans-boundary space or region, Iguazú or the like (eg, Schweitzer, 2000). Generally, however, this region was institutionalized under the name Triple Border, sometimes mentioned in capital letters (eg. Cardín, 2013; Renoldi, 2015), in other cases with lower case letters (eg. Barvinsk, 2014). The bibliography on this tripoint is abundant and varied. The focus is on smuggling and small-scale trade, which is outside of what states consider to be legal (Cardin, 2013; Renoldi, 2013, 2015; Rabossi, 2004). Some authors have been interested in the geopolitical and security imagination (Dreyfus, 2007), religiosity (Giménez Béliveau, Montenegro and Setton, 2005), tourist dynamics (Ferreira Cury and Fraga, 2013) or processes of cooperation and physical integration (Rhi Sausi and Oddone, 2010).

Besides the works centered on the Iguazútripoint, Sergio González Miranda’s production stands out. This author has been interested in the tripoints which, in the Andean space, Chile shares with its neighbors. Thus, it analyzed the "triple frontera andina" (Bolivia, Chile and Peru) and the "triple frontera circumpuneña" (Argentina, Bolivia and Chile) (González Miranda, 2007, 2009), the latter based on a previous proposal (Benedetti, 2007). Particularly, the first has aroused the interest of this and other authors because it is a considerably successful experience of building a tri-national region, based on paradiplomatic relations. There, the commonwealth of municipalities "Aymara sin fronteras" (Cf. Aranda Bustamante and Salinas Cañas, 2017, González Miranda, Rouviere and Ovando, 2008, among others) emerged. The Zapaleri tripoint, however, does not have a large bibliography. Some papers are interested in emerging linkages between the three tourism-related countries (Amilhat Szary and Guyot, 2009, Porcaro and Benedetti, 2016) or preHispanic populations (Nielsen, 2004).

Another South American tripoint that has generated some academic production is shared by Brazil, Colombia and Peru (Grisales, 2005). This is due, fundamentally, 
to the formation of a binational city in the Amazon jungle: Tabatinga (Brazil) -Leticia (Colombia) (see Aponte Motta, 2011 or Vergel-Tova, 2008). Bolpebra (Bolivia), Assis (Brazil) and Ińapari (Peru) are three other small localities of the other Amazonian tripoint, located on a trans-Amazonian bi-oceanic road, whose study, together with the previous one, is found in a book on urbanizations on the Amazonian borders (Zárate Botía, 2012).

Finally, the Cuareim tripoint - the southernmost in South America - has also attracted some attention. There we can mention the works of Galantini and Oddone (2013), focusing on cross-border cooperation schemes and infrastructure development, those of Merenson (2007) and Hartmann (2005, 2011), interested in narrative and construction of cultural identities, in addition to Ríos' doctoral thesis (2012), which reviews issues related to regional development.

Except for the mentioned bibliography, the situation of the tripoints and their surrounding area is rarely mentioned or even problematic, let alone in a comparative way. This article intends to make an initial contribution in this direction.

\section{SOME GENERAL COMPARISONS}

In the tables below, basic information about the five tripoints selected for this article was systematized. Table 1 shows the location (considering the physical environment and the geographic coordinates) and the year in which the location of each tripoint was determined (according to two countries, based on boundary treaties).

Unlike other regions of the world, such as Europe or Asia, where the cultural boundaries of the past (Foucher, 1988) were taken as criteria of national differentiation, in South America, where such a thing practically did not exist, hydrographic forms - mainly rivers - and orographic - fundamentally high summits and watersheds -, were favored, which in some cases should have been combined with straight lines. Thus, of the five tripoints selected, three are in confluences (Cuareim, Iguazú and Bahía Negra), one in the encounter of a river and a straight line (Esmeralda) and another on the top of a hill (Zapaleri).

The determination of a tripoint requires the concurrence of three delimitation processes, which supposes three different bilateral times. In all five cases, there was 
Table I

Tripoints of the countries of del Plata region. Location and year of its formal determination, according to bilateral documents.

\begin{tabular}{|c|c|c|c|c|c|c|}
\hline \multirow[b]{2}{*}{ Name } & \multirow[b]{2}{*}{ Previous warlike } & \multicolumn{2}{|l|}{ Location } & \multicolumn{3}{|c|}{ Year of their determination } \\
\hline & & Physical environment & $\begin{array}{l}\text { Geographical } \\
\text { coordinates }\end{array}$ & Pair of countries & Year & Documents \\
\hline \multirow{3}{*}{ Cuareim } & \multirow{3}{*}{$\begin{array}{l}\text { Provincias Unidas del Río de } \\
\text { la Plata-Empire of Brazil } \\
\text { (1825-1828) }\end{array}$} & \multirow{3}{*}{$\begin{array}{l}\text { Cuareim/ Uruguay river } \\
\text { (Isla Brasilera) confluence }\end{array}$} & \multirow{3}{*}{$\begin{array}{l}30^{\circ} 10^{\prime} 55.6^{\prime \prime} \mathrm{S} \\
57^{\circ} 37^{\prime} 39.1 \text { 'O }\end{array}$} & Argentina-Brazil & 1898 & Boundary Treaty, Art. 1 \\
\hline & & & & Argentina-Uruguay & 1961 & Boundary Treaty, Art. 1 \\
\hline & & & & Brazil-Uruguay & 1851 & Boundary Treaty, Art. 3 \\
\hline \multirow{3}{*}{ Iguazú } & \multirow{3}{*}{$\begin{array}{c}\text { Argentina-Brazil and Uruguay } \\
\text { against Paraguay } \\
(1864-1870)\end{array}$} & \multirow{3}{*}{$\begin{array}{l}\text { Iguazú and Paraná river } \\
\text { confluence }\end{array}$} & \multirow{3}{*}{$\begin{array}{l}25^{\circ} 35^{\prime} 32.7^{\prime \prime} \mathrm{S} \\
54^{\circ} 35^{\prime} 37.6^{\prime \prime O}\end{array}$} & Argentina-Brazil- & 1898 & Boundary Treaty, Art. 3 \\
\hline & & & & Argentina-Paraguay & 1876 & Boundary Treaty, Art. 1 \\
\hline & & & & Brazil-Paraguay & 1872 & Boundary Treaty, Art. 1 \\
\hline \multirow{5}{*}{ Esmeralda } & \multirow{5}{*}{$\begin{array}{l}\text { Conquest of Chaco } \\
\text { (Argentina, 1884- } \\
\text {-approx. 1910) } \\
\text { War of Chaco } \\
(1930-1936)\end{array}$} & \multirow{5}{*}{ Pilcomayo river } & \multirow{5}{*}{$\begin{array}{l}22^{\circ} 13^{\prime} 31^{\prime \prime} \mathrm{S} \\
62^{\circ} 38^{\prime} 11^{\prime \prime} \mathrm{O}\end{array}$} & Argentina-Bolivia & $\begin{array}{l}1925 \\
1941\end{array}$ & $\begin{array}{l}\text { Boundary Treaty, Art. } 1 \\
\text { Protocol, Art. } 1\end{array}$ \\
\hline & & & & \multirow{2}{*}{ Argentina-Paraguay } & 1939 & Complementary Boundary Treaty, Art. 1 \\
\hline & & & & & 1945 & Ratification. \\
\hline & & & & \multirow[t]{2}{*}{ Bolivia-Paraguay } & 1938 & $\begin{array}{c}\text { Treaty of Peace, Friendship and } \\
\text { Boundaries, Art. } 2\end{array}$ \\
\hline & & & & & 2009 & Signature of the Treaty \\
\hline \multirow{3}{*}{ Zapaleri } & \multirow{3}{*}{$\begin{array}{l}\text { War of Pacífico } \\
\text { (1879-1884) }\end{array}$} & \multirow{3}{*}{ Cerro Zapaleri } & \multirow{3}{*}{$\begin{array}{l}22^{\circ} 48^{\prime} 51^{\prime \prime S} \\
67^{\circ} 10^{\prime} 49^{\prime \prime O}\end{array}$} & Argentina-Bolivia & 1925 & Boundary Treaty, Art. 1 \\
\hline & & & & Argentina- Chile & 1904 & $\begin{array}{l}\text { Convention relating to the demarcation of } \\
\text { Puna de Atacama }\end{array}$ \\
\hline & & & & Bolivia-Chile & 1904 & Treaty of Peace and Friendship, Art. 2 \\
\hline \multirow{4}{*}{ Bahía Negra } & \multirow{4}{*}{$\begin{array}{l}\text { Triple Alliance } \\
(1860-1868) \\
\text { War of Chaco } \\
(1930-1936)\end{array}$} & \multirow{4}{*}{$\begin{array}{l}\text { Negro and Paraguay river } \\
\text { confluence }\end{array}$} & \multirow{4}{*}{$\begin{array}{l}20^{\circ} 10^{\prime} 11.1^{\prime \prime} \mathrm{S} \\
58^{\circ} 10^{\prime} 05.1 ” \mathrm{~W}\end{array}$} & Bolivia-Brazil & 1867 & Treaty of Ayacucho, Art. 2 \\
\hline & & & & \multirow[b]{2}{*}{ Bolivia-Paraguay } & 1939 & Treaty of Peace, Friendship and \\
\hline & & & & & 2009 & $\begin{array}{c}\text { Boundaries, Art. } 2 \\
\text { Signature of the Treaty }\end{array}$ \\
\hline & & & & Brazil-Paraguay & $\begin{array}{l}1872 \\
1927\end{array}$ & Complementary Boundary Treaty, Art. 1 \\
\hline
\end{tabular}

Source: own elaboration, based on international agreements of public access; Coordinates with Google Maps <https://www.google.com.ar/maps/place> 
a warlike precedent that served to distribute areas between the states in formation and to promote subsequent diplomatic processes.

Considering the year of the last diplomatic document, the tripoint Cuareim was the last to be fixed: in 1961, with the signing of the Uruguay River Treaty between Argentina and Uruguay. However, it had begun to be established there in 1828, in fact, with the signing of the peace treaty between the United Provinces of Rio de la Plata and the Empire of Brazil, after the War of Brazil or Guerra da Cisplatina, pillar for the formation of Uruguay, and for the confirmation of the homonymous river as international, as it had happened in the colonial past, separating the Spanish possessions from the Portuguese ones.

The warlike episode called War of the Triple Alliance, War of Paraguay or Great War accelerated the delimitation between Paraguay and its two eastern neighbors and the confirmation of Iguazú as a tripartite point. The Esmeralda milestone was established after the conquest campaigns of a considerable part of the Gran Chaco Sudamericano, by Argentina (begun in 1884 and extended until the first decade of the $20^{\text {th }}$ century) and the Chaco War, which involved the two Mediterranean countries of South America. Although the two tripoints shared by Bolivia and Paraguay were established in 1938, they were not formalized until 2009.

Finally, we can mention the War of the Pacific or the Salitre, which between 1879 and 1884 confronted Chile with Bolivia and Peru, and which opened, collaterally, a diplomatic process involving the first two and Argentina, for the definition of the domain over an extensive area, since then known as Puna de Atacama. Two bilateral documents of 1904 - one between Argentina and Chile and the other between Bolivia and Chile - closed the cycle of war and of geopolitical tension between the three countries, and established the Zapaleri as a starting point for the delimitation, which was also finally assumed as such by the Treaty of limits between Argentina and Bolivia (1925).

Thus, although the definition of the tripoints in itself was not a cause for conflict, it can be noted that they are located inside areas that towards the second half of the $19^{\text {th }}$ century were disputed, at the same time, by two or more countries. These disputes took place on both the battlefields and in the diplomatic world. In addition to the wars mentioned above, arduous diplomatic negotiations and the mediation of foreign powers were necessary to decide which part of the Gran Chaco (where the Esmeralda and Bahía Negra tripoints are located), the Puna de Atacama 
(Zapaleri tripoint), the Uruguay (Cuareim) and the Paranaan jungle (Iguazú) was entitled to each country.

Table 2 identified the populated centers located in the immediate vicinity of each tripoint, specifying the amount of population counted in the last round of national censuses (approximately in 2010). From there you can discern that the Cuareim and Iguazú tripoints are the two most populated. The first, with a locality in each of the countries involved, reaches 45,000 people concentrated in urbanizations. Iguazú has a population of more than half a million inhabitants, but only if it counts the population of the cities of Puerto Iguazú, Foz do Iguaçu and Ciudad del Este. In both Brazil and Paraguay there are other urban concentrations (some previously located, such as Hernandarias and Mingua Guazú in Paraguay) that make up an urban system close to one million inhabitants in a radius of $60 \mathrm{~km}$ around the tripoint.

Table 2

Tripoints of the countries of the del Plata region. Urban concentrations in your vicinity

\begin{tabular}{|c|c|c|c|c|c|}
\hline Tripoint & Country & City & $\begin{array}{l}\text { Distance to } \\
\text { milestone } \\
\text { approx. }(\mathbf{k m})\end{array}$ & Population & Year \\
\hline \multirow{3}{*}{ Cuareim } & Argentina & Monte Caseros & 8 & 35,922 & 2010 \\
\hline & Brazil & Barra do Quaraí & 8 & 4,012 & 2010 \\
\hline & Uruguay & Bella Unión & 9 & 3,873 & 2011 \\
\hline \multirow{3}{*}{ Iguazú } & Argentina & Puerto Iguazú & 0 & 42,849 & 2010 \\
\hline & Brazil & Foz do Iguaçu & 0 & 256,088 & 2010 \\
\hline & Paraguay & Ciudad del Este & 9 & 274,340 & 2010 \\
\hline \multirow{3}{*}{ Esmeralda } & Argentina & Santa Victoria Este & 6 & 1,809 & 2010 \\
\hline & Bolivia & Esmeralda & 2 & $\mathrm{~N} / \mathrm{D}$ & \\
\hline & Paraguay & - & & - & \\
\hline \multirow{3}{*}{ Zapaleri } & Argentina & - & & - & \\
\hline & Bolivia & - & & - & \\
\hline & Chile & - & & - & \\
\hline \multirow{3}{*}{$\begin{array}{l}\text { Bahía } \\
\text { Negra }\end{array}$} & Bolivia & - & & - & \\
\hline & Brazil & - & & - & \\
\hline & Paraguay & $\begin{array}{c}\text { Bahía Negra } \\
\text { (Puerto Pacheco) }\end{array}$ & 6 & 2,431 & 2010 \\
\hline
\end{tabular}

Source: own elaboration with information published in <http://www.montecaseros.gob.ar/> Paraguay (2015), Province of Salta, General Direction of Statistics, <http://estadisticas.salta.gov.ar/web/level3/2/111/101/null;> Province of Misiones, Provincial Institute of Statistics and Censuses, <http://www.ipecmisiones.org/censo-2010>; <http://www.ine.gub.uy/web/guest/censos-2011> 
Unlike the previous ones, the Esmeralda and Bahía Negra tripoints have very small settlements of less than five thousand inhabitants. The Zapaleri landmark, in an area with an altitude of more than 5 thousand meters above sea level, does not have stable population concentrations within a radius of $50 \mathrm{~km}$, making it one of the most depopulated South American tripoints.

Finally, Table 3 groups information on transport infrastructure, considering land, river and air.

\section{Table 3}

Tripoints of the countries of del Plata region. Transportation Infrastructure

\begin{tabular}{|c|c|c|c|}
\hline & Land Infrastructure & Fluvial Infrastructure & Air Infrastructure \\
\hline Cuareim & $\begin{array}{l}\text { Bella Unión-Barra do } \\
\text { Quaraí road bridge (railway } \\
\text { in disuse) (1976). Libres- } \\
\text { Uruguayana bridge } 70 \mathrm{~km} \\
\text { Routes: RNA } 1430 \mathrm{~km} / \\
\text { RNU 3 / BR: BR-472 }\end{array}$ & $\begin{array}{c}\text { Monte Caseros pier } \\
\text { (Argentina) and Bella Unión } \\
\text { pier (Uruguay) }\end{array}$ & Monte Caseros airdrome \\
\hline Iguazú & $\begin{array}{c}\text { Road bridges: Tancredo } \\
\text { Neves (Argentina-Brazil, } \\
\text { 1985) and de la Amistad } \\
\text { (Brazil-Paraguay, 1965) } \\
\text { Route: RNA } 12 \text { / BR-277 / } \\
\text { RNP } 7\end{array}$ & $\begin{array}{l}\text { Iguazú port (Argentina) } \\
\text { - Tres Fronteras port } \\
\text { (Paraguay) }\end{array}$ & $\begin{array}{l}\text { Cataratas (Foz do Iguaçu) } \\
\text { International Airport } \\
\text { Cataratas del Iguazú } \\
\text { (Puerto Iguazú) } \\
\text { International Airport } \\
\text { Guaraní (Ciudad del Este) } \\
\text { International Airport }\end{array}$ \\
\hline Esmeralda & Dirt road & Inexistent & Santa Victoria Este airdrome \\
\hline Zapaleri & Dirt road & Inexistent & Inexistent \\
\hline Bahía Negra & Rural road & $\begin{array}{c}\text { Pacheco Port (old name) over } \\
\text { Hidrovía Paraguay-Paraná }\end{array}$ & Dirt airdrome in Bahía Negra \\
\hline
\end{tabular}

Source: own elaboration based on Google Maps.

Considering the terrestrial infrastructure, the Iguazú tripoint stands out: two road bridges articulate the three cities. There, national routes have their starting points with connection to the greater metropolitan regions of the three countries: Buenos Aires (to 1,337 km); São Paulo $(978 \mathrm{~km})$; Asunción $(310 \mathrm{~km})$. In all three cases, these are asphalted roads which, by stretches, are motorways.

In a situation close to the previous one is the Cuareim tripoint, with a bridge between the starting points of Brazil and Uruguay. The tripoint has accessibility to 
asphalted roads, which connect with the metropolitan regions of Buenos Aires (619 $\mathrm{km})$, Sáo Paulo $(1,547 \mathrm{~km})$ and Montevideo $(616 \mathrm{~km})$. However, Monte Caseros does not have a bridge that crosses the Uruguay River, so the interconnectivity between the localities of the tripoint is limited.

The remaining three tripoints are those with the worst land transport infrastructure. In all three cases they connect with their respective territories through dirt or gravel roads. In turn, they are at the greatest distance with respect to their capitals or important metropolitan regions.

River infrastructure is key in tripoints located on rivers, especially the Cuareim: as Monte Caseros and Bella Unión do not have a road bridge, mobility is made possible by a river crossing. The same happens in the tripoint Iguazú: between Puerto Iguazú and Ciudad del Este a road bridge has not been built and, in its replacement, as an alternative to the road connection through Foz do Iguaçu, boats are used.

With regard to air transport, the Iguazú tripoint stands out. Three international airports have been built there. This is an indicator of the strategic and commercial importance of the area. Much of the air movement is related to tourism and commercial activities there. In the vicinity of Zapaleri tripoint there are no runways for aircrafts and in the remaining two there is an aerodrome in each case.

\section{CUAREIM TRIPOINT}

The Cuareim tripoint was fixed in an area of former Guaraní and Charrúa occupation. During the colonial period the area was controlled by the Jesuits, in particular, within the estancia Yapeyú (Silva Sandes, 2015). This tripoint began to be established as a result of the delimitation between Brazil and Uruguay, formalized in the treaty of 1851 (Article 3). The demarcation was carried out between 1852 and 1862 (Dorfman, França and Assumpção, 2016) and thus it was registered in the cartography of the time. Between Argentina and Brazil, the settlement of the interstate boundary followed the Triple Alliance War and the United States diplomatic mediation for the definition of the domain in the area called Las Palmeras (in the Misiones area). Finally, the Treaty of Limits of 1898 established in its act 1 that the dividing line, which runs along the thalweg of the Uruguay River, 
would begin in front of the mouth of the river Cuareim. This tripoint was formally completed a century later. During the first half of the $20^{\text {th }}$ century, Argentina and Uruguay maintained for their territorial differentiation the modus vivendi that came from traditional use, based on the line marked along which boats of greater draft circulated (Benedetti, 2015). It was only in 1961 that they signed the Treaty of Boundaries of the Uruguay River: it established an approximately normal line to the two margins of the river, between the south-western point of the Brazilian island and the parallel of Punta Gorda.

One of the difficulties that the countries of the del Plata region had was the presence of islands on the course of the rivers taken as reference for the delimitation. This is the case of the Uruguay River, which became a controversy between Brazil and Uruguay. At the mouth of the Cuareim there is an island of approximately $1 \mathrm{~km}^{2}$, called Brazilian, currently within the Brazilian territory. This was due to the settlement of boundaries between Argentina and Brazil, without the participation of Uruguay, which led to that island being incorporated into Brazil. This situation was answered by Uruguay (Cf. Acuña, 2005), but it did not become a cause which hampered bilateral relations.

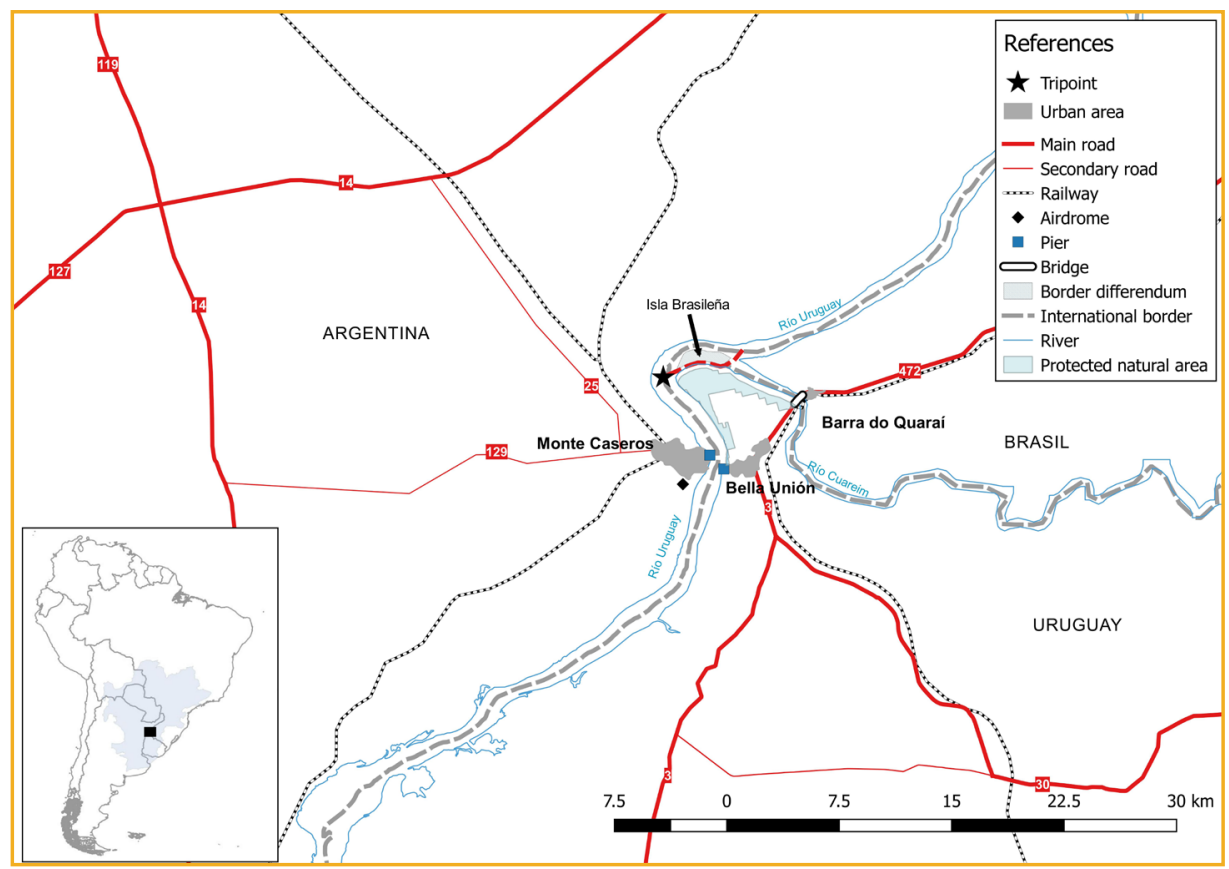

Figure 2. Tripoint Cuareim.

Source: author. 
The area has been the subject of different bilateral actions focused on their cities. Between Argentina and Uruguay, in 1987, the Monte Caseros-Bella Unión Frontier Committee (now called the Integration) was formed, while between Barra do Quaraí and Bella Unión, Brazil and Uruguay established an integrated control area, in the framework of MERCOSUR.

It is an urbanized tripoint. On the Brazilian side is Barra do Quaraí, a population established in 1814 as part of the Portuguese advance towards the south. This advance was the origin of the war with the United Provinces of the Rio de la Plata, which preceded the creation of the State of Uruguay in 1828. Bella Unión emerged towards 1829, as part of the formation of Uruguay and the prolegomena to this demarcation with Brazil. It was founded in 1853 under the name of Santa Rosa (Mena Segarra 1969) and then adopted its current name. Meanwhile, the province of Corrientes, currently within Argentina, established at that time a guard in the area known as Paso de Higos, which was later named Monte Caseros (Ríos, 2012).

These three localities did not have a great population growth. Monte Caseros stands out with 35,922 inhabitants, similar to the size that other Argentine cities on the border with Brazil have. The growth of Monte Caseros is related to citrus and rice production, but also to the proximity $(30 \mathrm{~km})$ to the road corridor of the Uruguay River located on the Argentine side, structured by RN 14, part of the Chile-MERCOSUR integration axis. Compared with other cities in the rest of the borders of Brazil with Argentina and Uruguay and Uruguay with Argentina and Brazil, Bella Union and Barra do Quaraí are far below their demographic size. They have concentrations close to 4,000 people, while Uruguayana exceeds 150 thousand inhabitants, Salto exceeds 100,000 and Artigas reaches 40,000, to mention the nearest cities.

Different research shows an important integration between the population of these three cities, especially between Monte Caseros and Bella Unión (vg. Galantini and Oddone, 2013). However, the interconnection between them is still incomplete. Bella Unión and Barra do Quaraí are linked by a railroad bridge (the latter in disuse), built in 1976. It connects RN3 (Uruguay, towards Montevideo) and BR-472 (Brazil, towards Uruguayana). Since the 1980's different actions have been carried out in favor of the construction of a bridge between Monte Caseros and Bella Unión, located opposite each other. Since 2010, after the meeting of the presidents of both countries, studies have begun to assess the economic and 
environmental feasibility of the implementation of this project, which has not been executed yet. For mobility, meanwhile, the river mode is used, through the local piers.

Finally, it can be pointed out that, unlike the other tripoints, there is no indigenous presenceoractiveethnogenesis processes at present. As in theentireborderofBrazilwith Uruguay and Argentina, there is a culture based on the Portuñol as a mixed language.

\section{IGUAZÚ TRIPOINT}

The history of this tripartite landmark is linked to the control of the river Iguazú and its waterfalls, and the Paraná jungle. The area was discovered by the Spanish at the beginning of the $17^{\text {th }}$ century. The natives were placed in reservations by Jesuit missionaries, but they suffered the pressure of the Portuguese bandeirantes in their slave-hunting expeditions, which is why these practices were soon deactivated. The area remained outside the territories occupied by the colonists and then by the emerging national states for most of the $19^{\text {th }}$ century, until the end of the Triple Alliance War, around 1870 (Schweitzer, 2009). With that war, the process of interstate delimitation was also accelerated. The treaty of boundaries between Brazil and Paraguay dates back to 1872 and in its article 1 establishes the thalweg of the Paraná river, where Brazilian possessions begin in Iguazú. A treaty was signed between Argentina and Paraguay in 1876, which in article 1 declares that the east and south of Paraguay is divided from Argentina by half of the main channel of the Paraná River from its confluence with the Paraguay River, until finding the limits of the Empire of Brazil by its left margin. This boundary, between Argentina and Brazil, was traced following the Iguazu River as a dividing line. In the zone of the tripoint, the demarcation did not generate controversies, but it did upstream, in the area known as Palmeras, requiring the arbitration of the United States (Lima 2015). The treaty of limits dates from the year 1898, and article 3 mentions the mouth of the Iguazú River in the Parana as the end point of the boundary initiated, towards the south, in the Cuareim river.

As a way of consolidating its control in the area, the Argentine state created the National Territory of Misiones (1881). By the 1930s, on both the Brazilian and Argentine sides, the state presence on the border and the attempt to occupy border areas increased. This led to the creation of two national parks, which were devices 


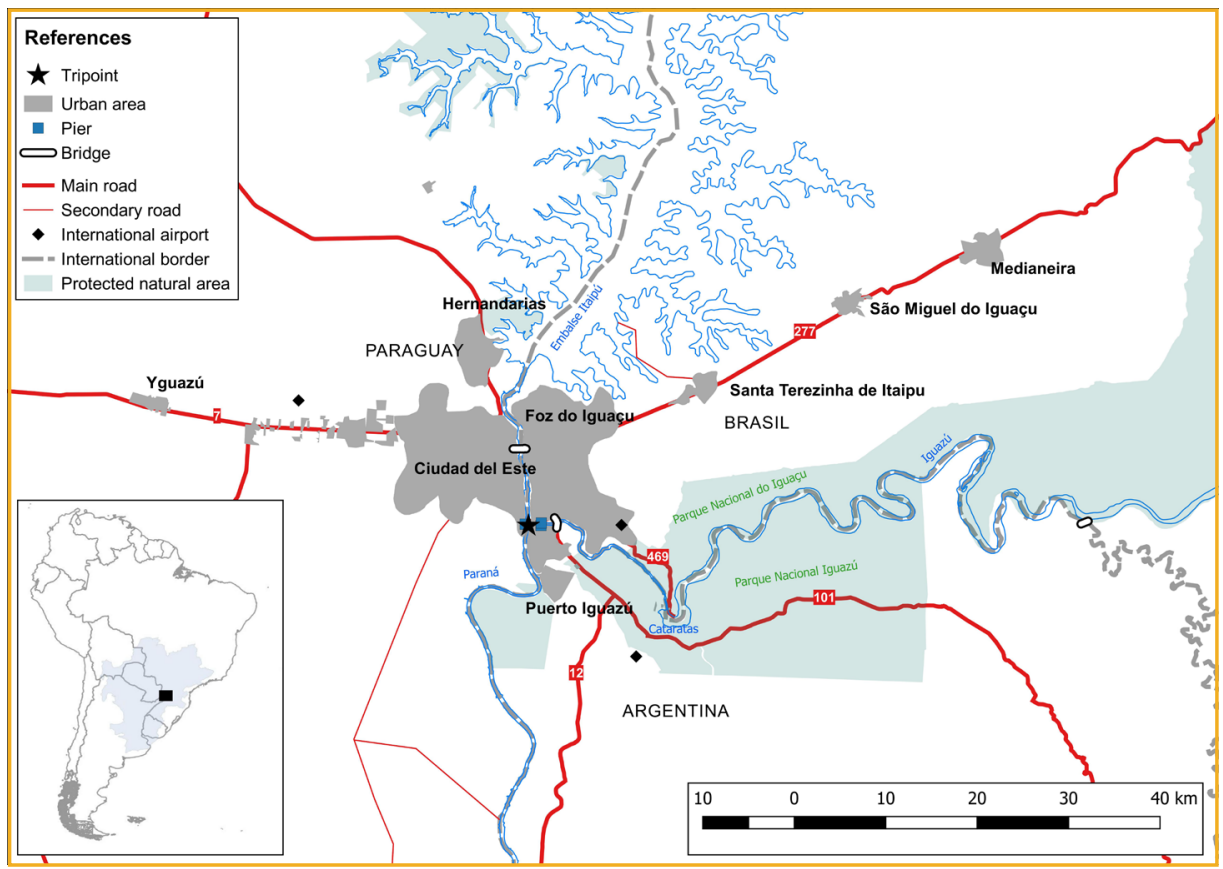

Figure 3. Tripoint Iguazú.

Source: author.

designed to ensure effective state presence in this region: the Argentine side of the Iguazu National Park in 1934 and the Brazilian side of the Iguaçu National Park in 1939 (Ferrero and Pyke, 2015; Ferreira Cury and Fraga, 2013). This happened in a context marked by the rivalry between Argentina and Brazil, with the parks acting as buffers between the two territories.

By the 1950s, in turn, Brazil tightened ties with Paraguay, for example, by transforming the Brazilian port of Paranaguá into a free zone for the latter. Thus, the Paraguayan foreign trade, which until then was practiced through the Rio de la Plata, was reoriented towards Brazil, reducing its dependence on Argentina since the Great War. In the tripoint, this approach resulted in the valorization of lands in the upper Paraná area, in the colonization of the Paraguayan riverbank of Paraná and in the construction, in 1965, of the first bridge (called de la Amistad). Besides, the Itaipú hydroelectric dam was built and there was an intense occupation of the Brazilian-Paraguayan border, in addition to the construction of the route BR-277 (from Lima 2015). The consolidation of the Paraguayan side of the tripoint was due to an active policy, led by the Paraguayan dictator Stroessner, who promoted 
the "March to the East", reorienting Paraguayan territory in that direction, instead of the historical link to the south, from Asunción towards the Rio de la Plata. That generated land colonization and population attraction, much of which came from the state of Rio Grande do Sul (Schweitzer 2009). In the long run, this led to a more intense transformation of the landscape on the Brazilian and Paraguayan sides of the Iguazú tripoint.

The three cities near the tripartite point were founded as a direct reflection of the process of intensifying the presence of the three national states. Brazil founded a military colony in 1897, initially called Vila Iguassu, later renamed Foz do Iguaçu. On the Argentine side, at the end of the $19^{\text {th }}$ century there was a small settlement, which began to be called Puerto Aguirre and then changed to Puerto Iguazú. There the command of the national park was installed and still remains. The consolidation of both localities is related to the proximity to national parks and to the promotion of tourism. Later, around 1945, the colonies MingaGuazú, Presidente Franco and the village of Hernandarias, on the Paraguayan side, were created. With the "March to the East", the Puerto Flor de Lis was founded (1957), renamed as Presidente Stroessner Port, in honor of the homonymous dictator, finally renamed in 1989 as Ciudad del Este. Because of the strategic importance of the area, and despite the considerable distance from the main metropolitan regions of the three countries (more than 1,000 in Buenos Aires, more than 300 in Asunción and about 830 in São Paulo), this tripoint has high accessibility, through national asphalted routes in the three directions.

Until the middle of the $20^{\text {th }}$ century, the economy in the area of the Iguazú tripoint was based on the exploitation of natural resources and on yerba and timber production (Fogel, 2008). The creation of the tax-free zone in Ciudad del Este towards the 1960s, the construction of the two bridges and, above all, the Itaipu dam in the 1970s and the continuous growth of tourism in the area caused a demographic explosion that transformed the tripoint definitely. To this, the progress of the soybean frontier was added, from Brazil to Paraguay, which led to an expulsion of small Paraguayan producers, mainly to Ciudad del Este. This population could not be absorbed by the formal market, which triggered the formation of networks of small traders (generally considered smugglers or fraudsters, since they introduce illicit products or do not pay customs tariffs), based in Ciudad del Este and fundamentally projected to different cities in Brazil. In this way, the networks of baggers arose. These workers are intermediaries between traders located 
in Paraguay and other traders located in the neighboring country, or sometimes distribute on their own account. Other workers, known as "laranjas", are hired informally to transport a certain amount of merchandise to Brazil in exchange for a predetermined payment (Cardin, 2013).

Since the 1970s, activities related to energy production (especially in Foz do Iguaçu), trade (especially in Ciudad del Este) and tourism (Iguazú Falls) have been highlighted. Ciudad del Este is a port of arrival for products mainly from Southeast Asia, through Chilean or Brazilian ports, which are then legally and illegally reexported to Brazil and Argentina. It also functions as a destination for illicit products (stolen cars, drugs, weapons) that in many cases come from neighboring countries and then re-enter there through different maneuvers, or other products (such as soy or coffee) that come from Brazil and are re-exported from Paraguay. In comparison to its neighbors, Foz do Iguaçu presents a greater diversity of activities, including commercial, industrial and tourism-related services, while in Puerto Iguazú there is a predominance of tourism activity (Dreyfus, 2007).

Unlike other tripoints, this one acquires significant relevance in the domestic life of one of the countries, namely Paraguay. This is due to the strategic position of Ciudad del Este in relation to Brazil, having greater structural dependence in commercial and logistical matters, since it is through the ports of Brazil that a major part of the soy production is channeled.

These are lands of the Guarani culture. After the failure of the Jesuit colonization, until the end of the $19^{\text {th }}$ century the area of the Iguazú tripoint had no notable presence of white population. The Mbyá Guaraní population has historically developed their socioeconomic practices in jungle areas, with high mobility and multi-locality (Pissolato 2004). Currently, this population is distributed in the southern and southeastern states of Brazil, Misiones in northeastern Argentina and eastern Paraguay. Mobility is fundamental to maintain the social relations of a dispersed population. Throughout the $20^{\text {th }}$ century, Guarani communities moving through the Paraná forest were persistently pressured by the advance of monocultures, agricultural colonies and urban development. In the case of Paraguay, since the 1950s there was systematic persecution and eviction. In all three cases, many members of these communities were incorporated as cheap labor, in some cases seasonal. Thus, there was a progressive fragmentation of the Guarani territories and the rupture of networks of interethnic exchange (Okulovich, 2013). 
On the other hand, a large mass of workers who were unemployed at the end of the construction of the Itaipú dam and many others who came from Brazil as part of the agricultural process also gave rise to a human, linguistic and cultural group known as "Brasiguayos". It is estimated that some 400,000 people (almost $7 \%$ of Paraguay's population) live and work in the most informal way and without any legal protection (Dreyfus, 2007). Many of them integrate the social group known as sacoleiros, engaged in small-scale trade.

In addition to the people from the three countries and from Uruguay, there is also the presence of people from China, Taiwan and Korea, as well as people from Lebanese, Syrian and other Middle Eastern nationalities, who arrived in the area in the 1980s. This population is not so visible through their number, but through their symbolic repercussions. This is because the area was associated with Islamic terrorism and that gave it notoriety over other social characteristics. The Muslim population was stigmatized as terrorist activists (Renoldi, 2015).

All this, besides showing that it is the most populated tripoint in South America, accounts for its highly cosmopolitan character.

\section{ESMERALDA TRIPOINT}

Located in the interior of the South American Great Chaco, the Esmeralda tripoint started to be set on the first decades of the $20^{\text {th }}$ century. After a long diplomatic process, in the treaty of 1925, Argentina and Bolivia agreed to set the boundary at the eastern end of the Pilcomayo River. Argentina and Paraguay, after the war of the Triple Alliance, signed the Treaty of Friendship, Trade and Navigation, which reestablished bilateral relations. At the same time, they signed the first boundary treaty between the two countries, establishing de jure the Paraná, Paraguay and Pilcomayo rivers as territorial boundaries. The difficulty arose with the third river. The treatment of the boundary in the section of the Pilcomayo River was submitted to the arbitration of the American president, who determined, in 1878, that the main arm of the Pilcomayo was to be taken as reference. But it is a plain river, which overflows, changes its course and at times dries up. This has hindered the demarcation in all its extension, and even the location of the milestone tripoint. In 1905 both countries signed an agreement creating a double commission to carry out hydrological studies, in order to determine the main arm of the river. Everything 
was delayed, among other reasons, by the development of the war between Bolivia and Paraguay. The Treaty of Peace, Friendship and Boundaries between Bolivia and Paraguay of 1938 (with the mediation of Argentina, Brazil, Chile, the United States of America, Peru and Uruguay) established, with inaccuracies, the boundary (with Argentina in the south and Brazil in the north). Finally, in 1939, Argentina and Paraguay signed an agreement that established the definitive limit in the Pilcomayo, which had to be supplemented by another agreement in 1945. It was stipulated that a special commission should design a plan of works to obtain a definitive indictment of the river and give stability to the dividing line. This never happened, and at the same time there was a displacement of the course. The tripartite milestone could not be placed in the corresponding place until 2016. Finally, Argentina and Bolivia, with a Protocol of 1941, confirmed that the final limit in the section of the Pilcomayo River had the Esmeralda landmark as end point.

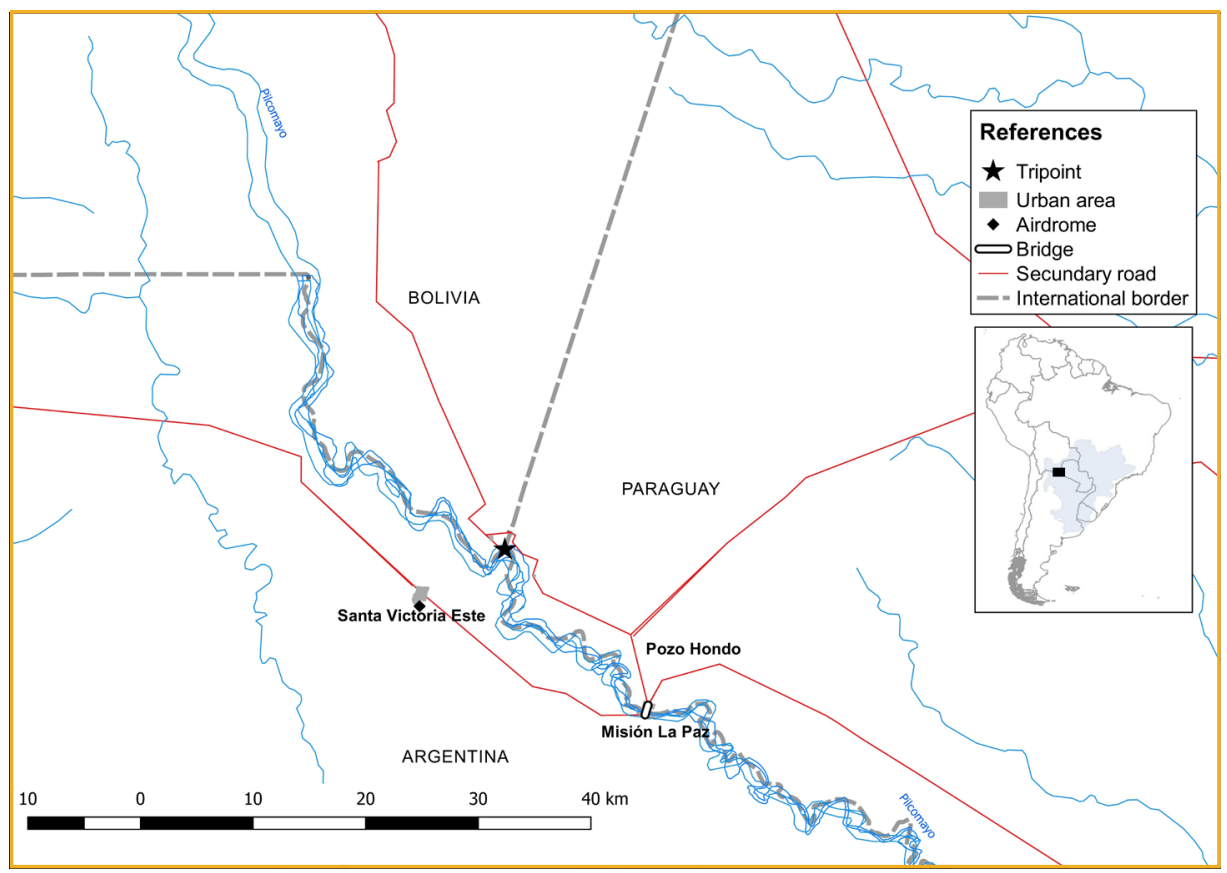

Figure 4. Esmeralda tripoint.

Source: author. 
Apart from some measures linked to the security of the three countries, the area was not the object of any promotion of their productive development. Because it is a plain area with a river that dries for seasons, the crossing of the limit does not offer greater difficulties. There is no active civil society claiming the construction of infrastructure.

It is a sparsely populated area, with no large consolidated populations. The most important locality, which is on the Argentine side, is Santa Victoria Este with about 2 thousand inhabitants. On the Bolivian side there is a town called Esmeralda, whose population is still lower. The area is barely accessible via dirt roads. It is located at a great distance from the national capitals (in a straight line: $1,400 \mathrm{~km}$ from Buenos Aires, $800 \mathrm{~km}$ from La Paz and $600 \mathrm{~km}$ from Asunción), but also from important cities of lower hierarchy. Downstream the Pilcomayo are Mision La Paz (Argentina) and Pozo Hondo (Paraguay). The first one was created with the missionary objective of concentrating the indigenous Chaco population at around the middle of the $20^{\text {th }}$ century (Trinchero 2000). Between the two sites, a bridge was built in the 1990s as part of continental integration policies. However, this project was not completed, as the routes that originated there were not asphalted.

It is occupied by a very mobile population of Wichí, Chulupí and Chorote groups. These populations were intensely exploited from the expansion of the Argentine border towards the Great Chaco. Traditionally nomadic, associated with hunting, gathering and fishing, these groups were forced overtime to be included as seasonal labor for different agricultural plantations. There are also Creole populations devoted to the extensive breeding of animals.

\section{ZAPALERI TRIPOINT}

The definition of this tripartite point located in the High Andean area was a derivation of two episodes. The first was the War of the Pacific (1879-1884), through which Bolivia lost control of the Atacama Desert and its departure to the sea by sovereign territory. The other relevant episode, subsequent to that war, was the diplomatic process developed between Argentina and Chile - in the general context for the definition of the boundary along the mountain range - to determine which country had the dominion of the area known as Puna de Atacama, located to the east of the homonymous desert. With the mediation of 


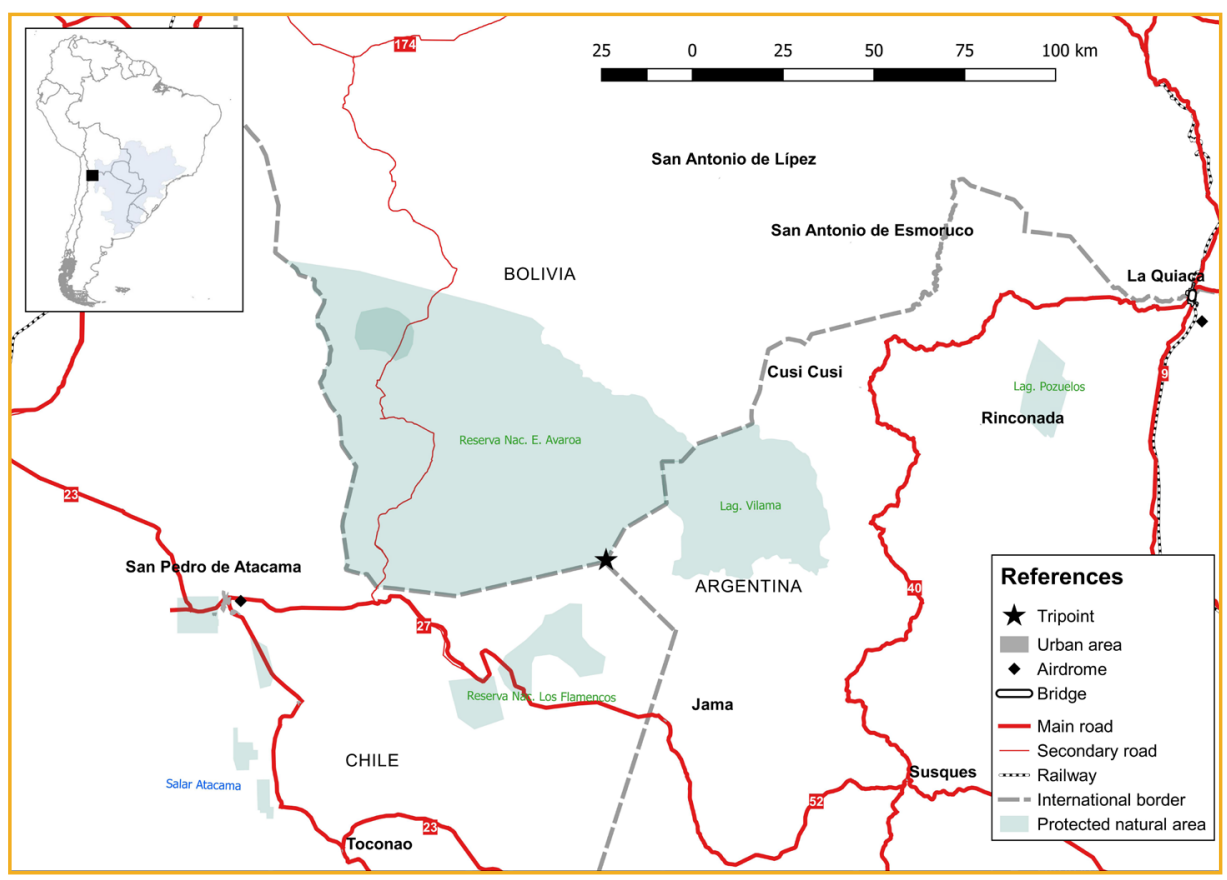

Figure 5. Tripoint Esmeralda.

Source: author.

the United States, it was accepted that much of that area should be integrated with Argentina (Benedetti, 2005). The determination of Zapaleri hill as tripoint was reached in 1904 . This was made possible by the Treaty of Peace and Friendship of 1904 between Bolivia and Chile, which closed the cycle of war: Bolivia ceded the area of Atacama to Chile in perpetuity. Likewise, Article 2 of that treaty stipulated that hill as a starting point for the binational boundary. On the other hand, the Convention concerning the Limitation Demarcation in the Puna de Atacama, also of 1904, signed between Argentina and Chile, located in that hill the starting point of the mutual delimitation. The Boundary Treaty of 1925, between Argentina and Bolivia, finally determined that the boundary began in the extreme west with a line from Cerro Zapaleri or Sapalegui $(5,649 \mathrm{~m})$ in the north-northeast direction.

Of the five tripoints considered here, it is the only one located at the top of a hill, which has an altitude of over 5,600 meters above sea level. For that reason, no permanent location was established in its immediate vicinity. The nearest, all very small, are several tens of $\mathrm{km}$ away: Rinconada $(110 \mathrm{~km}, 500$ inhabitants) or Susques (105 km, 1,200 inhabitants) on the Argentine side; San Pedro de Atacama 
on the Chilean side ( $103 \mathrm{~km}, 5,600$ inhabitants, Quetena (71 km, 800 inhabitants) or San Antonio Lípez (120 km, 200 inhabitants) on the Bolivian side, all equally distant and scattered.

The legal crossing points between the three countries are also distant from Zapaleri tripoint:

Bolivia-Chile: Cajón landmark, at $65 \mathrm{~km}$, is a gravel road with bad roads; more to the north, about $200 \mathrm{~km}$, is the road-rail passage of Ollagüe. It is a connection of some relevance for mining and commercial activity.

Argentina-Chile: Jama Pass, $55 \mathrm{~km}$, is part of one of the South American integration axes, called Capricorn. It is a zone of transit of products entered through the ports of the north of Chile towards Paraguay. Next to the area a population of about 100 people arose, mostly officials linked to the border control. Further south, about $200 \mathrm{~km}$ in a straight line, there is the railway pass of Socompa (also known as Huaytiquina), currently in disuse.

Argentina-Bolivia: La Quiaca-Villazón pass at $180 \mathrm{~km}$. It is a paved road that integrates the old corridor from Buenos Aires to Lima. Until the 1990s it was also a railway crossing.

The absence of roads in the vicinity should not be confused with absence of mobilities. Historically, the Andean footsteps of the outskirts were used by caravans of llamas, led by settlers of the high Andean lands, with the aim of making exchanges. During the $20^{\text {th }}$ century, different civil society groups from the cities of San Salvador de Jujuy (northwest of Argentina) and Calama (northern Chile) sought the opening of a mountain pass that communicated them. One of the alternatives considered was a gorge located in the vicinity of the landmark, used by caravans and muleteers. This was finally discarded due to the difficulties that it offered to the traffic, in front of which finally became the northernmost pass between Argentina and Chile, namely Jama (Tomasi and Benedetti, 2013). Still in the present, the closest passes to Zapaleri are used by llamas and sheep farmers, who move around the area in search of water and grassland, or to make other exchanges. Especially to the east, on the border between Argentina and Bolivia, about $40 \mathrm{~km}$ from the tripoint, there is an intense mobility of llama producers, who perform peasant trade fairs, in small towns such as CusiCusi (Argentina) or San Antonio de Esmoruco (Bolivia) (González, 2012). 
Therefore, as González Miranda (2009) points out, Zapaleri tripoint has cartographic, diplomatic and geopolitical functions, but no singular sociological or cultural ones: it does not represent a particular symbol for its population. The greatest interactions are established between cities like Jujuy, Salta, La Quiaca, in Argentina; San Pedro de Atacama, Calama, Ollagüe, in Chile; Villazón, Uyuni, San Cristóbal, in Bolivia, all located at great distances from this tripoint.

The present inhabitants of this zone inherited part of the Andean cultural tradition. Many of them, especially in the Bolivian sector, speak the Quechua language or the Aymara language. From the Argentinean side they were historically known, and now are ascribed, as coyas. In addition to the breeding of llamas and sheep (the latter introduced by the Spanish), they grow potatoes and quinoa on small-scales. In addition, some perform some small-scale mining activities gold washing, salt extraction (Nielsen, Calcina and Quispe, 2003). Likewise, the presence of mining activity, linked to the exploitation of borates or lithium, among other minerals, is notorious. In this area some areas of nature reserve have been created in the three countries (Reserva de Fauna Andina Eduardo Avaroa in Bolivia, Ramsar site Laguna Vilama in Argentina and Salar de Tara in Chile). These reserves are part of a complex of high Andean sites located around the Zapaleri which have generated a flow of tourists, in permanent growth, very notably from the Chilean side, with epicenter in San Pedro de Atacama (Porcaro and Benedetti, 2016).

\section{BAHÍA NEGRA TRIPOINT}

In the South American pantanal region, shared with Bolivia, Brazil (where the largest extension is found) and Paraguay, is the fifth tripoint studied in this article. Its location began with the so-called Treaty of Ayacucho of 1867, which delimited the territories of Bolivia and Brazil. Bolivia undertook a diplomatic battle to secure a sovereign exit on the western bank of the Paraguay River towards the Atlantic. This area is known as Triángulo Man Césped or Dionisio Foianini triangle. It is about $48 \mathrm{~km}$ of beach on the Paraguay River. This treaty was rectified by the Petrópolis Treaty of 1903 to resolve the issue in the Acre region at the northern end of the border. In the extreme south, however, the confluence of Paraguay with Bahía Negra was already fixed by article 2, as a starting point. The boundary treaty between Brazil and Paraguay of 1872 mentioned Paraguay as a divisor, but did not 
specify the extreme point. This occurred in the Treaty of Complementary Limit: in its article 1, it identified the confluence of the Negro and Paraguay rivers as a point of completion for the delimitation. As in the case of the Esmeralda landmark, between Bolivia and Paraguay, it ended up being defined with the Treaty of Peace, of 1938 .

In the area of the tripoint there are activities linked to commercial fishing and livestock; in recent times, iron mining has gained some relevance, as well as the agricultural advance, which represents a threat to the marsh ecosystem. In the vicinity of the tripoint the concentrated populations are scarce and dispersed.

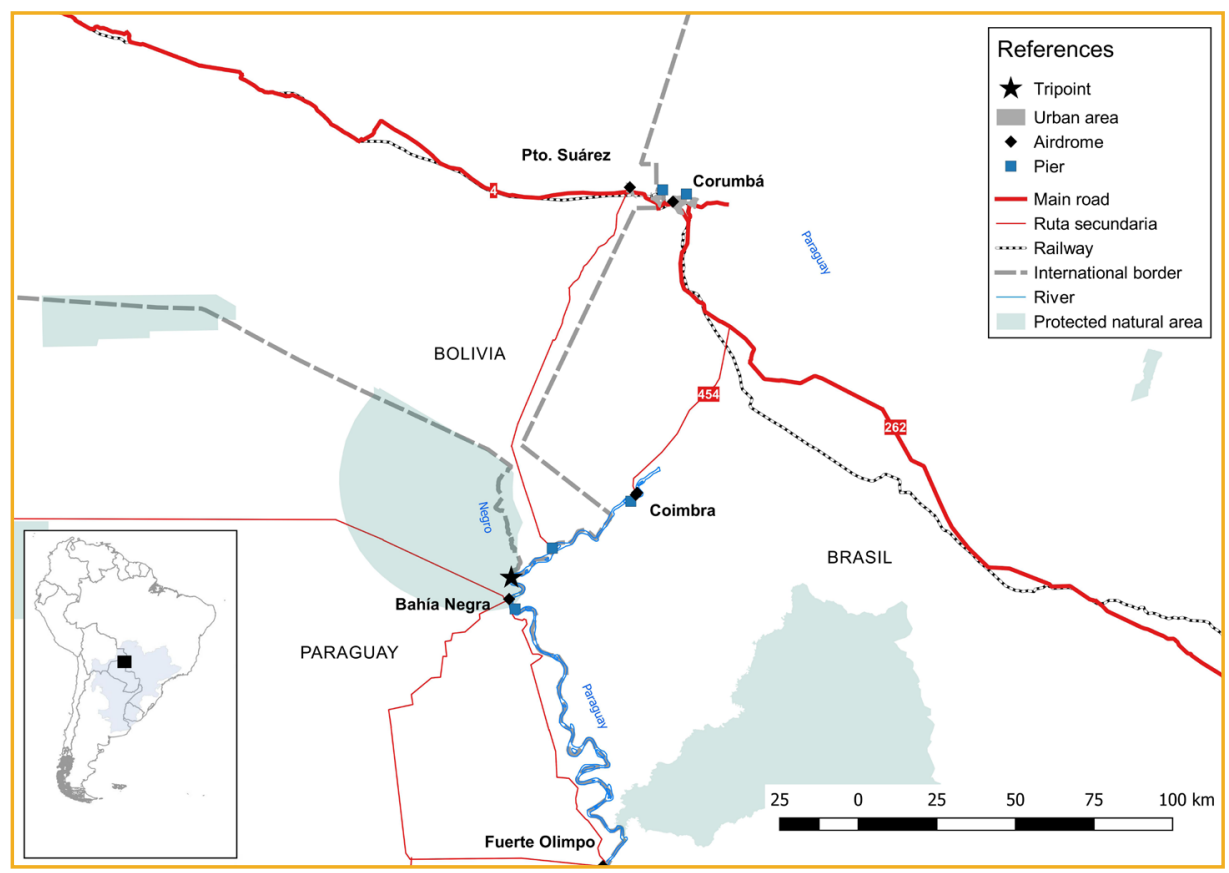

Figure 6. Emeralda tripoint.

Source: author. 
The most important, on the Paraguayan side, is Bahía Negra, with about 2,500 inhabitants, near which there are others, smaller, all on the Paraguay River, such as Puerto Leda, Puerto Nuevo and Puerto Voluntad. On the Brazilian side, about $50 \mathrm{~km}$ from the tripoint is Coimbra. Formerly known as Fuerte Coimbra, it is a village dating from the late $18^{\text {th }}$ century and linked to the Portuguese advance over Mato Grosso (Areces, 2004). It currently has less than one thousand inhabitants. The nearest Brazilian town of some importance is Corumbá, located $100 \mathrm{~km}$ to the north. On the Bolivian side stands Puerto Busch, also of military origin, and also on the Paraguay River. The construction of a commercial port was projected, but never materialized (El Diario, 1904/2015). The nearest Bolivian town is Puerto Suárez, in front of Corumbá, about $130 \mathrm{~km}$. The connectivity of these small agglomerations is guaranteed by the Paraguay-Paraná Waterway system, in addition to some aerodromes, such as the one in Bahía Negra. The riverside population moves downstream to Fuerte Olimpo (the most important urban center of the Paraguayan Pantanal) or upstream to Corumbá or Puerto Suárez (Gonçalves and Isquierdo, 2011). The routes are dirt, mostly impassable.

The native population is mainly Chamacoco, located on the bank. Traditionally they exploited the marsh resources. The pressure of the capitalist advance led to generate different forms of family economy, which in many cases subsist on the use of fish resources. There are also Creole populations of Paraguayan and Brazilian origin, which reflects the progress of agricultural and livestock activities towards the area (Carrón, 2003).

\section{CONCLUSIONS}

A tripoint is a point where the boundaries shared by three states are initiated. Around them emerge singular areas in the international border system, of a high complexity, due to the presence and the multiple relations between three more or less differentiated cultural, economic and political organizations. Until now, references to this border typology were concentrated, almost exclusively, in the Iguazú tripoint. Very few academic papers account for the remaining 12 tripartite dynamics. This work sought to focus on five tripoints: Careim, Iguazú, Esmeralda, Zapaleri and Bahía Negra. They are those which were formed as a result of the process of territorial differentiation between the five countries of del Plata region, 
that is, between Argentina, Bolivia, Brazil, Paraguay and Uruguay, as well as Chile (in the case of tripoint Zapaleri).

The areas where the tripoints mentioned can be found were of little or no importance for the Iberian crowns in colonial times. One exception is the area where the Cuareim tripoint is located, which was most clearly incorporated into the colonial territorialities, in the Jesuit dominions. The area of the Iguazú, which was initially conquered, finally remained separated from the colonial centers. Although the area where the Zapaleri was located was also part of the colonial territorialities, its limited accessibility due to the topography kept it away from the main routes. The areas where the Esmeralda tripoint was established, in the South American Great Chaco, and the Bahía Negra in the Pantanal, were located outside the lands conquered by Spain and Portugal. All these areas, however, were inhabited by native populations of the continent, with unique productive and cultural developments in each case.

The first to be located was the Cuareim, at the beginning of the 1850s. The rest took place quite later. From the last decades of the $19^{\text {th }}$ century, the other areas, finally tripartite, were involved in war and diplomatic conflicts that revealed the interest of all states to expand and consolidate their territorial base. The areas where these other tripoints were found were the last corners of the del Plata region on which it was necessary to decide to which state each domain corresponded. This involved a multiplicity of treaties and protocols, field studies and changes in the final location of the tripoints. All this, too, expresses the complex set of regional power balances deployed in the process of formation and mutual differentiation of the territories of the South American national states.

The attention given to the tripoints by individual countries or in pairs or trios of countries re-differentiated them from the 1930s onwards. The greater relative development of the Argentine and Brazilian economies in comparison to the other countries of the region, their persistent rivalry and the change in influences on Uruguay and Paraguay, made Iguazú (especially) and Cuareim tripoints monopolize the greater attention in the development of public policies, the promotion of agricultural colonization and the deployment of mechanisms of state control (such as the creation of national parks). More recently, links with the growth of Islamic terrorist action, the importance of the area in terms of energy and commerce, and the visibility of the tourism promotion linked to the waterfalls have made the Iguazú a central place, transforming it into the tripoint or triple border by antonomasia. 
The Esmeralda, Zapaleri and Bahía Negra tripoints maintained a confined and even almost forgotten position in terms of media and academic attention during most of the $20^{\text {th }}$ century. Only a few training projects for the construction of transport corridors of continental scale gave a certain visibility to these last three tripoints.

\section{REFERENCES}

Acuña, Y. (2005). La isla brasilera, las aguas jurisdiccionales del río Uruguay y ¿Dónde está el tripoint?, Boletín n. 8, Servicio Geográfico Militar, República Oriental del Uruguay.

Amilhat-Szary, A. and S. Guyot (2009) El turismo transfronterizo en los Andes centrales: prolegómenos sobre una geopolítica del turismo, Si Somos Americanos (Chile), IX (2007-2), .58-93.

Aponte Motta, J. (2011). La frontera en el espacio urbano: expresiones del límite entre Leticia (Colombia) y Tabatinga (Brasil), Mundo Amazónico 2. 199-223.

Aranda Bustamante, G. and Cañas, S.S. (2017) Paradiplomacia aymara: Empoderamiento en la frontera. Estudios Fronterizos 18(35), p. 90-106.

Areces, N. (2004). La frontera entre Mato Grosso y Concepión. De Tierra de Indios Bárbaros a espacio militarizado y colonizado, Cuadernos de Historia, Serie Ec. Y Soc., 6, Secc Art., Córdoba, pp- 41-70.

Barvinsk, G. M. (2014). La trata de mujeres con fines de explotación sexual en la región de la triple frontera, Revista Latinoamericana de Estudios de Seguridad 14, p. 68-78.

Benedetti, A. (2005). La Puna de Atacama como construcción geopolítica. Transformaciones territoriales posteriores a la Guerra del Pacífico (1889-1900). Revista Si Somos Americanos. Revista de Estudios Transfronterizos 7(2), p. 155-183.

Benedetti, A. (2007). "La región circumpuneña. Algunas consideraciones para iniciar el debate” In: Alejandro Corder Tapia Editor, Actas del VI Seminario Internacional de Integración SubRegional: Sociedades de Frontera, Montaña y Desierto, Ediciones del Instituto de Estudios Internacionales, INTE, Universidad Arturo Prat, Iquique, p. 14-26.

Benedetti, A. (2015). The Argentina-Uruguay BorderSpace: A Geographical Description. Revista Frontera Norte 27(53), p. 35-61.

Cardin, E.G. (2013). Mecanismos de contrabando y tráfico en la Triple Frontera. In: Fronteras: rupturas y convergencias. Fernando Carrión y Víctor Llugshacomp. Quito: FLACSO (Sede Ecuador - Centro Internacional de Investigaciones para el Desarrollo) 306 p.

Carrón, J.M. (2003). Gran Pantanal en el Paraguay, Revista Población y Desarrollo 24, p. 77-87. 
Lima, F. R. F. (2015). O processo de ocupação da tríplice fronteira - Brasil, Argentina e Paraguai. Revista de Geografia (UFPE) 32(3), p. 10-20

Dorfmann, A.; França, A.B.C. and M.B. Assumpção, (2016) Fronteiras Sul-americanas: História, formas e processos contemporâneos, Anuário Unbral das Fronteiras Brasileiras 2, p .79-123.

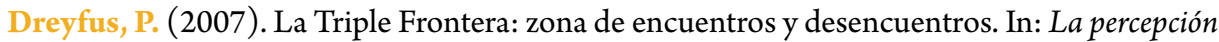
de Brasil en el contexto internacional: perspectivas y desafíos, tomo 1: América Latina / Wilhelm Hofmeister, Francisco Rojas A. \& Luis Guillermo Solis R., [organizadores]. - Rio de Janeiro: Konrad-Adenauer-Stiftung, 368 p.

Ferreira Cur'y, M.J. and Fraga, N.C. (2013). ConurbaçãoTransfronteiriça e o Turismo na Tríplice Fronteira: Foz Do Iguaçu (Br), Ciudad Del Este (Py) e Puerto Iguazú(Ar). Revista Rosa dos Ventos 5(3), p. 460-475, jul-set, 2013.

Ferrero, B. and Pyke, L. I. (2015). Naturaleza y Frontera. El Parque Nacional Iguazú y el proceso de consolidación del Estado argentino en la frontera argentino-brasileña (1880-1934) Sociedad y Discurso Número 28, p. 135-167.

Fogel, R. (2008). La región de la triple frontera: territorios de integración y desintegración, Sociologias 20, p. 270-290.

Foucher, M. (1988). Fronts et frontières. Un tour du monde géopolitique, Fayard, Paris.

Galantini, E. and Oddone, N. (2013). Monte Caseros, Bella Unión, Barra Do Quaraí: un escenario privilegiado para la cooperación transfronteriza en el corazón del Mercosur. Merlo: Instituto Superior Dr. Arturo Jauretche.

Giménez Béliveau, Montenegro, V. S. and Setton, D. (2005). El campo religioso en la Triple Frontera: entre el arraigo nacional, los anclajes étnicos y los movimientos transfronterizos. Revista de laEscuela de Antropología 10, p. 179-192.

Gonçalves, J. C. and Isquierdlo, S. W. G. (2011). Fronteira Brasil, Bolívia e Paraguai no município de corumbá: uma abordagem sobre as diferentes divisões politico administrativas, Revista Geográfica de América Central, Número Especial EGAL, 2011- Costa Rica, II. 1-13.

González Miranda, S. (2007). La emergencia de la triple-frontera andina (Perú, Bolivia y Chile), Bogotá: Convenio Andrés Bello, 159 p.

González Miranda, S. (2009). El Norte Grande de Chile y sus dos Triple-Fronteras: Andina (Perú, Bolivia y Chile) y Circumpuneña (Bolivia, Argentina y Chile). Cuadernos Interculturales de la Universidad de Valparaíso 7(13), p. 27-42.

González Mirranda, S. L. Rouviere and Ovando, C. (2008). De "Aymaras en la frontera” a "Aymaras sin fronteras". Los gobiernos locales de la triple-frontera andina (Perú, Bolivia y Chile) y la globalización. Diálogo Andino 31, 2008.

González, N. M. (2012). Territorio en pugna: la Feria Binacional de Camélidos en la Provincia de Jujuy (Argentina). Revista de Estudios Regionales 8, p. 99-120.

Grisales, G. (2005). ¿Amerita la frontera de Colombia, Brasil y Perú una zona de integración trinacional? Aldea Mundo 10 (18) p. 54-61. (Universidad de los Andes, Táchira, Venezuela) 
Hartmann, L. (2005). Performance e experiência nas narrativas orais da fronteira entre argentina, brasil e uruguai. Horizontes Antropológicos 11(24) p. 125-153.

Hartmann, L. (2011). Performances culturais: expressões de identidade nas festas da fronteira entre Brasil, Argentina e Uruguai, Etnográfica [Online], 15 (2). Retrieved from: <http:/ / etnografica. revues.org/918> DOI: 10.4000/etnografica.918

Mena Segarra, E. (1969). Límites y fronteras, Nuestra Tierra 42, Montevideo.

Merenson, S. (2007). "El “rincón de la rinconada”: lecturas de la frontera, narrativas de la nación. Bella Unión, República Oriental del Uruguay”. Papeles de trabajo. Año 1, n. 2, Informes de Trabajo, Retrieved from: <http://www.idaes.edu.ar/papelesdetrabajo/paginas/Documentos/02_10 Informe\%20de\%20Silvina\%20Merenson.pdf> .

Nielsen, A. (2004). Aproximación a la Arqueología de la Frontera Tripartita Bolivia-ChileArgentina, Chungará., p.861 - 878 .

Nielsen, A., Calcina, J. and Quispe, B. (2003). Arqueología, turismo y comunidades originarias: una experiencia en NorLípez (Potosí, Bolivia)Revista Chungará, v. 35, n. 2,369-379.

Okullovich, E. (2013). Sociedad Guaraní-Mbyaem Argentina. Arte, identidade y supervivência. Escuela de Posgrado, Doctorado en Metodología de Investigación en el Ámbito de las Artes Plásticas y Visuales, Granada: Universidad de Granada, Facultad de Bellas Artes.

Pissolato, E. (2004). Mobilidade, multilocalidade, organização social e cosmologia: a experiência dos grupos Mbya-Guarani no sudeste brasileiro. In: Revista Tellus, año 4, n. 6. Campo Grande, 65-78.

Porcaro, T. and Benedetti, A. (2016). "El turismo, la nueva panacea del desarrollo. Cooperación y paradiplomacia en el espacio fronterizo circumpuneño”. En Gonzalez M., S., Cornago P., N. y Ovando S., C. (Eds.), Relaciones transfronterizas y paradiplomacia en América Latina. Aspectos teóricos y estudio de casos. Santiago de Chile: RIL editores.

Rabossi, F. (2004). Dimensões da espacializacao das trocas - A propósito de mesiterose sacoleiros em Ciudaddel Este, Ideacao, 6,151-176, UNIOESTE, Campus, FOZ DO IGUAÇU.

Renoldi, B. (2013). Fronteras que caminan: relaciones de movilidad en un límite trinacional, Revista Transporte y Territorio /9, pp. 123-140.

Renoldi, B. (2015). Estados posibles: travesías, ilegalismos y controles en la Triple Frontera, Etnográfica [En línea], vol. 19 (3) | 2015, Puesto en línea el 27 octubre 2015, consultado el 02 octubre 2016. Retrieved from: <http:// etnografica.revues.org/4049> ; DOI 10.4000/ etnografica.4049.

Rhi Sausi, J. L. and Oddone, N. (2010). Cooperación e Integración Transfronteriza en el MERCOSUR: El caso de la Triple Frontera Argentina-Brasil-Paraguay”. In: Maira, L. (editor) La política internacional subnacional en América Latina. Buenos Aires, Del Zorzal, p. 209-258.

Ríos, G. (2012). Fronteras en la Integración del Mercosur. La Triple Frontera Barra do Quaraí (Brasil) - Bella Unión (Uruguay) - Monte Caseros (Argentina). Tesis doctoral, Universidad de la Republica, Facultad de Ciencias Sociales, Departamento de Sociología, Salto. 
Schweitzer, A. (2000). Intégration régionale et aménagement du territoire dans le MERCOSUR: frontières, réseaux et dynamiques transfrontalières, Lille.

Schweitzer, A. (2009). Dinámicas espaciales y territorios de la integración en las fronteras del Iguazú, In: Guibert, Martine et al. (ed). Le bassin du Río de la Plata. Développement local et intégration régionale, Presses Universitaires du Mirail, Toulouse, p. 313-330.

Silva Sandes, E. (2016). El espacio fronterizo en el río Uruguay: entre fragmentación y cohesión regional (1991-2014), Paraná: Tesis para optar al Título de Doctor en Ciencias Sociales por la Universidad Nacional de Entre Ríos.

Tomasi, J. and Benedetti, A. (2013). Territorialidades multiescalares. El Paso de Jama y el eje de capricornio, vistos desde un pueblo de pastores puneños (Susques, Jujuy, Argentina). In: Nicoletti; M.A. and P. Núñez (ed.) Araucanía - Norpatagonia: la territorialidad en debate. Perspectivas ambientales, culturales, sociales, políticas y económicas. San Carlos de Bariloche: IIDyPCa

Trinchero, H. H. (2000). Los dominios del demonio. Civilización y barbarie en las fronteras de la Nación. El Chaco Central, Eudeba, Buenos Aires.

Vergel-Tova, E. (2008). Ciudades gemelas en fronteras amazónicas: estudio de caso Leticia y Tabatinga, Cuadernos de Vivienda y Urbanismov 1(2), p. 348-393.

Zárate Botía, C. G. (ed) (2012). Espacios urbanos y sociedades transfronterizas en la Amazonia. Leticia - Amazonas - Colombia: Universidad Nacional de Colombia Sede Amazonia. Instituto Amazónico de Investigaciones Imani, 279 p. 


\section{TERRITORIAL DYNAMICS ON THE BRAZILIAN URUGUAYAN CROSS-BORDER: CASE STUDY OF THE TWIN CITIES (JAGUARÃO, BR-RIO BRANCO, UR)}

\section{Heleniza Ávila Campos \& Andressa Lopes Ribeiro}

\section{ABSTRACT}

This article shows the results of a research project developed since 2013. It aims to discuss the socio-spatial relationship between twin cities on the Brazilian-Uruguayan border, based on their strategic functions: centers of defense and important nodes of commerce and capital. The cities of Jaguarão (BR) and Rio Branco (UR) were used in this case study. Consideration was given to their important role as nodes in the regional capital circuit. We seek to analyze the territorial configuration of these cities, recognizing an integrated urban and dynamic culture, which, to a lesser extent, has been influenced by the national policies of their particular countries. The role of upper and lower circuits of the economy in these cities is also highlighted, with trade expansion (formal and informal) encouraged by a "free shops" policy in the region.

KEYWORDS Twin cities, urban form, Brazilian-Uruguayan border. 
This article aims to discuss the relationship between cities in the border regions between Brazil and Uruguay, which are contemporaneously influenced by internationally established economic dynamics but gain little support from binational policies at a local level. The selected case study is the urban space configured by the twin cities of Jaguaráo (BR) and Rio Branco (UR). Located on the border between the Brazilian state of Rio Grande do Sul and the Department of Cerro Largo in Uruguay, Jaguarão has a population of 28,271 inhabitants (Brazilian Demographic Census IBGE, 2010) and Rio Branco, of 14,604 inhabitants (Uruguayan Demographic Census, INE, 2011). The two cities unite across Baráo de Mauá International Bridge over Jaguaráo River, as small urban settlements situated in the plain of Pampas of the Platine Basin (Figure 1).

In the article, we seek to analyze the territorial configuration of these cities, considering two significant aspects: the recognition of the changes that occur historically by virtue of the defense conditions and, at the same time, the commercialization present in the corrugation that persists there and that reveals historical interactions between the cities. This aspect reinforces an integrated urban culture and its own dynamics, somewhat removed from the policies of Brazilian and Uruguayan national governments. Nevertheless, contemporary defense strategies have changed, adapting their structure and use of technology relative to the trafficking of people and goods, and altering the territorial and economic logic of these localities. A second aspect concerns the current participation of the upper and lower circuits of the urban economy in this border region and the expansion of international trade through the policy of free shops; aspects which have implanted a new economic and social order in these places, as well as the economic character linked to their defense aspect.

Through a morphological analysis of this set of cities, we see more than just urban development strategies. The relationship between old and new political processes of this Platine border is also demonstrated. On the one hand, the historical differences in layout obey the precepts of Portuguese/Spanish military engineering; on the other hand, the great spatial fragmentation of the Uruguayan settlement relative to the sector that concentrates import trade, compared with the urban cohesion of Jaguarão. Such incongruities infer specificities characteristic of a permanently contested Platine region, albeit culturally sound. 


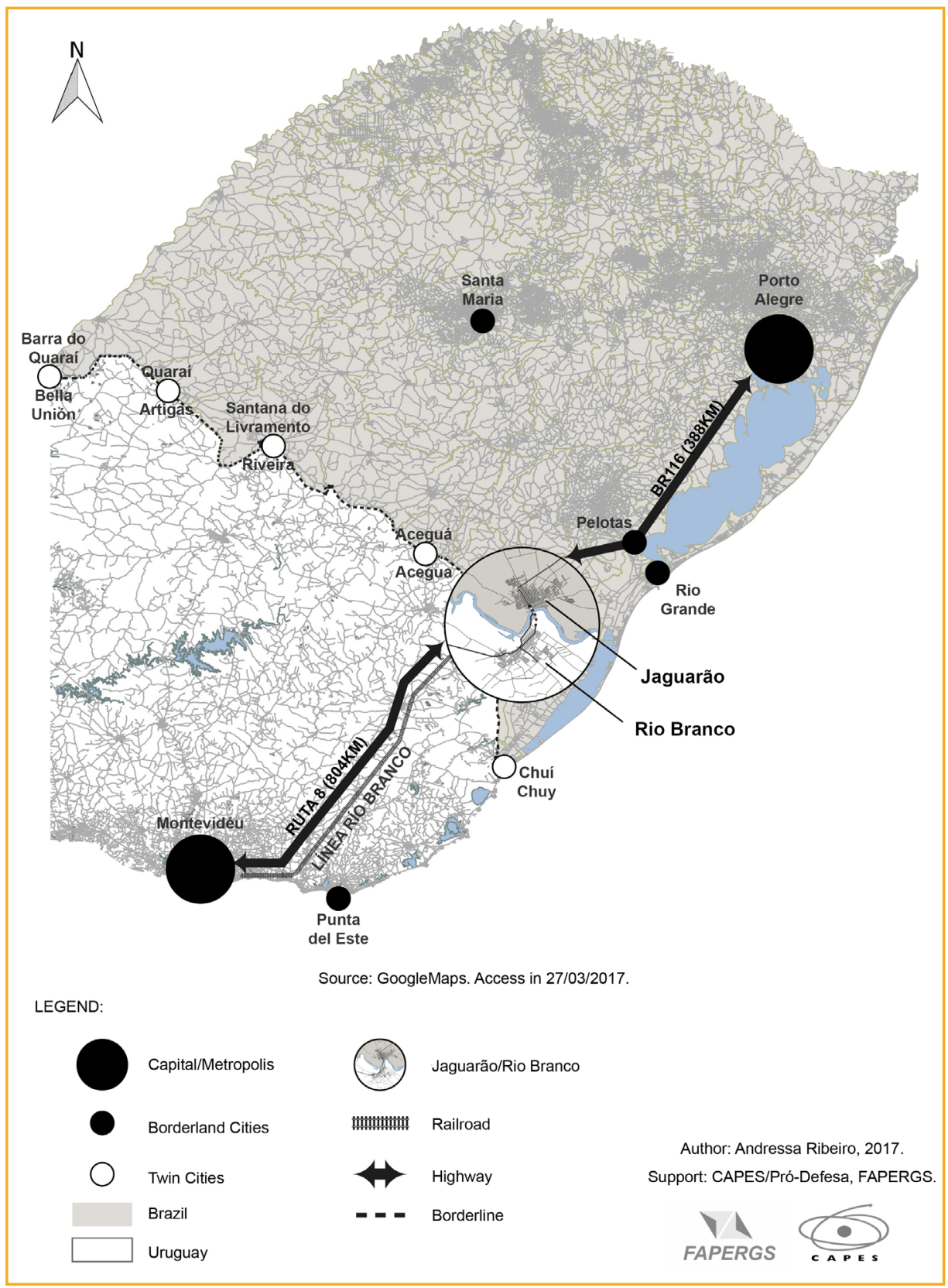

Figure I. Location of Jaguarão and Rio Branco on the Brazilian-Uruguayan border. 
The article developed from a bibliographical and documentary research about the cities and their regional context, to highlighting the fieldwork carried out in 2016. The experience of direct contact with the border reality, the urban structure of both twin cities and the dynamics of flows generated by commercial activities at different scales allowed us to reflect on the different relationships that exist between cities and the particularities of cross-border everyday life.

The article is organized in four parts, and includes also an introduction and final considerations. Firstly, an understanding of border regions considering the difference between defense and security (peculiar to these regions) and, secondly, the contextual particularity of these twin cities. Next, the main characteristics of the border region are analyzed and finally, the results of the fieldwork carried out, including the presentation of maps showing the defense dynamics and productive activities of the twin cities of Jaguarão and Rio Branco.

\section{URBANIZATION IN BORDER REGIONS: THE SPECIFICITY OF TWIN CITIES}

The concept of a cross-border region includes in its conception the idea of defense space and, not infrequently, its status as a trading post. However, these regions are also important strategic components in the circuit of capital, revealing conflict between local and global territorial dynamics. Meanwhile, there is an economic dynamic that increasingly allows for commercial flow linked to the international market. There is also local reality of space, that has been confronted and permanently adapted by these external forces, but which still retains its peculiar characteristics.

This concept is not recent and has been reformulated as a result of social changes, to its current technical-scientific-informational environment. Rückert \& Dietz (2013) argue that the concept of borders, cross-border regions and crosstransnationalism is still under construction, especially when linked to a multiscale perspective.

The importance of the border region in the specific context of the urban network demonstrates the feasibility of re-reading and pondering socio-spatial values in the urban and regional planning process, linked to actions, both vertical and horizontal 
(Santos, 2006), with which these territories interact. Notice here one perspective of cross-border linking that still persists, even with the challenges of urban and regional planning in the contemporary world (Rückert \& Dietz, 2013).

The condition of multiple influences to which the border territory is subject leads local and regional economic agents to create better conditions for exchange and interaction. In this situation, the more accessible the spaces for the goods, services and people circulation, the greater the condition of viability and intensity of trade and services. Thus, economic organizations lead the population to experience multiple interactions, generating and intensifying horizontal relations. In this context, we find cities, which represent material (systems of objects) and functional (systems of actions) places that influence the interests of various agents in the border region. In these cities, the singular relationship between society and nature becomes a strategic point of the urban network.

Twin cities are two or more urban spaces limited by administrative policies and located in a specific situation in border regions: the border. Machado (2010) emphasizes the importance of developmental policies for these peculiar realities, either in the creating of a system of bi or multinational cooperation, or as strategic centers of border geopolitics, in the control of illegal trafficking and smuggling networks.

In Brazil, we find 'twin cities' legally defined by Portaria $n^{\circ} 125 / 2014$, as cities with more than 2.000 inhabitants within the Brazilian border ${ }^{1}$. According to the diversity of its physical characteristics, the Ministry of National Integration published the "Proposal for Restructuring of the Border Range Development Program" in this context (Brasil, 2005), identifying five types of cross-border interaction, as shown below:

- Margin: interaction in which the border population on each side of the international boundary maintains little contact with each other, except for family visiting or ordinary trade. This interaction is characterized by the absence of physical infrastructure and little State investment;

\footnotetext{
1 The Border Belt is a territorial area $150 \mathrm{~km}$ wide within the Brazilian territory from the border line. This Belt is defined by Federal Law 6,634/1979, regulated by Decree No. 85,064 of August 26, 1980. Its content was ratified by the Federal Constitution of 1988, (Article 20). Its definition aims to identify the Brazilian political-administrative units that are the target of specific national security rules and public civil engineering works.
} 
- Buffer zone: areas where State restricts or prohibits access to the belt/ border zone, creating national parks, protected areas or Reserves, such as indigenous lands;

- Fronts: interaction characterized by settlement fronts in which there is a strong presence of State through military action. Cultural (selective affinities), indigenous and military influences are also denoted;

- Capillary: more open and spontaneous interaction that occurs only at local level, for example, in the case of fairs. There are strong exchange relationships between neighbors with limited communication networks, almost always resulting from unstrained integration, with little State intervention or investment;

- Synapse: refers to the presence of a high degree of exchange among border populations supported by contiguous States. The existing physical connections, like bridges, favor this type of interaction, encouraging agents linked to border trade either in upper (free trade zones, free shops, hotels and chain stores, for example) or in lower (money changers, cross-border bikers, street venders) circuits of urban economy.

On the Brazilian South Region, there are synaptic and capillary interactions predominant on the unequal territories of the twin cities, supporting opening spaces for market flow and physical-military control of National defense. In the following section, we will discuss some defense and security aspects on the Brazilian border that interfere directly with twin cities.

\section{DEFENSE AND SECURITY IN THE SOUTHERN BRAZILLAN BORDER}

Security and defense are different concepts, although they are often understood as synonyms. In Brazil, PND (Politica Nacional de Defesa- National Defense Policy) is constituted in a document published by the Ministry of Defense, according to Decree No. 5,484, June 30, 2005, updated in 2012 (Brasil, 2012). In this document, security is understood as the "condition in which the State, society or individuals feel free of risks, pressures or threats, including extreme needs." Therefore, specific aspects provide the society's feeling and collective perception relative to its territory. 
Defense means the "effective action to obtain or maintain the desired degree of security". In other words, it is the concrete and material gesture, generally carried out by the State, to establish the control of its internal limits. Thus, the assumption of security is maintained. Being so close, the meanings of these concepts are misunderstood: sometimes there are security policies that are more defense perspectives than otherwise. Hector Saint-Pierre (2011, p. 408) points out that this conceptual confusion generates imbalance and conflict in the treatment of international relations.

With this uncritical incorporation of concepts, it has been admitted, for example, that migration constitutes a threat to sovereignty and that poverty "could jeopardize the security of the State and democracy". In fact, the deficiencies of the State offer the economic, political and social conditions, which, in part, are the reason for some of these migrations.

In international relations, the political units, understood as territorially defined countries establish spatial boundaries among themselves, each trying to preserve the political, cultural and economic values of their regions. This presupposes, therefore, the recognition of values as well as methods of management among the States involved. These relationships are almost always legally established through laws or, in their absence, through agreements or negotiations for the recognition of the sovereignty of each country, without which it is not possible to establish the political relations that arise at an international level.

The Declaration on Security in the Americas, published in 2003 (OEA, 2003), claims that security must be multidimensional, recognizing that the context of globalization and transnationalism interferes with and extends the list of security "threats" in international relations, such as:

- terrorism, transnational organized crime, the world drug problem, corruption, money laundering, illicit arms trafficking and its connections;

- extreme poverty and social exclusion of large sectors of the population which also affect stability and democracy;

- natural and man-made disasters, HIV/AIDS and other diseases, health risks and environment deterioration; 
- trafficking of human beings;

- attacks on cybersecurity;

- possible or eventual damage in case of accident during the maritime transport of potentially dangerous materials, including oil, radioactive material and toxic waste;

- possible access, possession and use of weapons of mass destruction as well as their transport by terrorists.

The same Declaration strongly emphasizes the need for commitment to international cooperation in dealing with social and political dilemmas and conflicts and enabling economic projects of an international character. In this context, a security regime has been established in Latin America linked to mechanisms of mutual agreement, even if the use of force between National States is possible. Fagundes $(2015$, p. 2) also points out the following:

According to the Comparative Atlas "Comparativo de La Defensa en América Latina y Caribe da Red de Seguridad y Defensa de la América Latina" (2014) 94\% of Latin American countries regularly carried out some activity or operation linked to public security: combating drug trafficking, urban patrolling, permanent border control.

So, the action of the Armed Forces has a direct and crucial participation in several cities of cross-border regions, especially those strategically situated. Indeed, the accessibility to national territory calls into question the understanding of risk to national security, from a military and administrative territorial perspective.

In the Brazilian Southern region, there is a growing search to facilitate the flow of capital and commodities since the creation of MERCOSUR (1991). Multilateral economic interests in this region have a direct impact on the implementation of defense strategies and, although fragile, bilateral agreements between Brazil and Uruguay demonstrate close political initiatives on cross-border integration (New Agenda for Border Cooperation and Development, 2002). It is up to the National States to adjust their defense policies to border dynamics in their different upper and lower urban circuits. 


\section{UPPER AND LOWER CIRCUITS OF ECONOMY IN CITIES OF BORDER REGIONS}

The integration and cooperation process between Brazil and Uruguay, although still politically slow, echoes a tertiary sector development in the South Brazilian border relative to the different scales of social labor division. In this sense, it is important to highlight the theory of the upper and lower circuits of urban economy as a contribution to the discussion of these border regions. This theory was developed in late 1970s by Milton Santos, who considered the upper circuit as activity systems in the tertiary sector linked to the great capital circulation present in the cities (banks and headquarters of multinational companies) and to the national and international systems that make it real, such as transport systems and financial market.

On the other hand, the lower circuit consists of the activity system linked to intensive work in more horizontal and small-scale coverage and centered in the retail trade within popular reach. The lower circuit meets demands not explored by the upper one, reinforcing its prominent position relative to conditions and differences in production and consumption patterns (Silva, 2007).

In border regions, the presence of free shops in twin cities intensified these circuit connections since the creation of Law No. 12,723/2012, which governs the customs trading regime. In fact, some free shops had already been installed in the 1980s, but the Federal Law of 2012 expanded the investments in this type of business on a large scale. Conceived as a project to boost local border economies by Uruguay, this kind of big store stimulated local economies linked to the tertiary sector, but also implemented a system of financial movement linked to international capital flow and, therefore, susceptible to oscillations. This intensification of commercial activities increased the existing differences between the neighboring cities that have generated new social and spatial dynamics.

The local analysis from the perspective of complementarity between upper and lower circuits allows us to understand the economic and spatial interaction between formal and informal activities (often also illegal). In Rio Branco, for example, free shops have promoted new employment opportunities, either in their own stores or in informal commerce and exchange offices, all located very close. In Jaguarão, we notice that there is a greater concentration of enterprises linked to upper circuit 
(financial agencies, carriers, hotels) and that support commercial activities. Twin cities, therefore, create conditions for adapting their realities through their spatial practices, as will be shown below.

\section{THE STUDY AREA ON THE BRAZILLAN URUGUAYAN BORDER}

The twin cities studied are located on the Brazilian Uruguayan border and form a hub between these two countries. They form part of a relatively well-integrated South American regional urban network, if compared to other border regions in Brazil. There are six sets of main urban spaces, as shown in Table 1, with their respective twins.

\section{Table I}

Area and total population of municipalities of twin cities Brazil-Uruguay

\begin{tabular}{lccc}
$\begin{array}{l}\text { Municipality } \\
\text { Twin city (Brazil) }\end{array}$ & $\begin{array}{c}\text { Total Pop. } \\
\text { (inhab.) } \\
\mathbf{2 0 1 0}\end{array}$ & $\begin{array}{c}\text { Municipality } \\
\text { Twin city } \\
\text { (Uruguay) }\end{array}$ & $\begin{array}{c}\text { Total Pop. } \\
\text { (inhab.) }\end{array}$ \\
\hline Barra do Quaraí & 3,669 & $\begin{array}{c}\text { Bella Unión } \\
\text { (Mun.) }\end{array}$ & 12,200 \\
Quaraí & 22,624 & Artigas (Capital) & 40,658 \\
S. do Livramento & 83,320 & Rivera (Capital) & 64,485 \\
Aceguá & 4,611 & Acegua & 1,511 \\
Jaguarão & 28,271 & Rio Branco & 14,604 \\
Chuí & 5,797 & (Mun.) & 9,675 \\
\hline
\end{tabular}

Source: Demographic Census (IBGE, 2010; INE, 2011).

In general, we observe that municipalities have low population rates. On the Brazilian side, we highlight Santana do Livramento, Jaguarão and Quaraí. In a less integrated form, these urban spaces participate in the urban network of the regional border, taking into account their distance from the nearest cities. It is a sparse urban network that articulates small cities with few services or dynamic economic activities. In some situations, the distance between these cities in the network is more than $200 \mathrm{~km}$. 
Chuí (BR) is the city furthest away from the others because of its physicalterritorial situation, historically marked by conflict. Rio Grande do Sul's relief is mostly low and flat, with seventy percent of its territory at less than $300 \mathrm{~m}$ altitude. Much of its southern half is dominated by fields. If, on the one hand, these support cattle creation, on the other hand, they allow the occupation of this territory by more regular urban structures. In fact, on the southern Brazilian border, territorial disputes, commerce (mainly charqueadas) and smuggling are always present, in contrast to other Brazilian border regions.

\section{SITUATION AND EVOLUTION OF THE TWIN CITIES}

Here is a brief description of the twin cities' main physical aspects, especially regarding their site. The urban space of Rio Branco stretches some distance from the banks of the river, following two main axis: the railroad tracks (still in operation) and Av. Saravia. The railroad acts as the boundary of the city's oldest occupation, where there are the most recent settlements, located to the southeast. However, it also links the city with the International Bridge of Baráo de Mauá.

Rio Branco's actual urban design is the result of a long adatation period, when the city was susceptible to Portuguese and Brazilian domination. Its creation represented a way of resistance to invasions, which may justify the apparent absence of planning in its general, clearly fragmented morphology. Rio Branco was founded by a Spanish Order in 1792 and named, at that time, Guardia de Arredondo, this being the more prosperous garrison of the three established at that time. In 1801, however, the territory was transferred to Brazilian command, remaining this way until 1851, when it was renamed Villa Artigas (1852). The name of Rio Branco appears only in 1915, after the definitive Treaty of Lands of 1910.

Across the river, there is Jaguarão, presenting a more compact configuration as it follows Jaguarão river bank in orthogonal urban design. The main street in Uruguay connects the bridge with BR-116, which gives access to the Brazilian road network. In the city's oldest square, Alcides Marques, there is the main church, the public market and the pier.

Even in the $17^{\text {th }}$ century, Jaguarão was occupied by a Spanish military garrison at a place known as Cerro da Pólvora, conquered afterwards by Brazilian troops 
in 1802. This remained there, justifying the urban area planning according to Portuguese military engineering rules (IPHAN, 2017). The city's formation was based on its highest limits, defined by Lagões River, Jaguarão River and Cerro da Pólvora (or Cerro da Enfermaria) in a town called Guarda do Serrito. This site offers tactic advantages for military installation (Figure 2). The current quarter was installed at the beginning of the $20^{\text {th }}$ century in the area around the river.

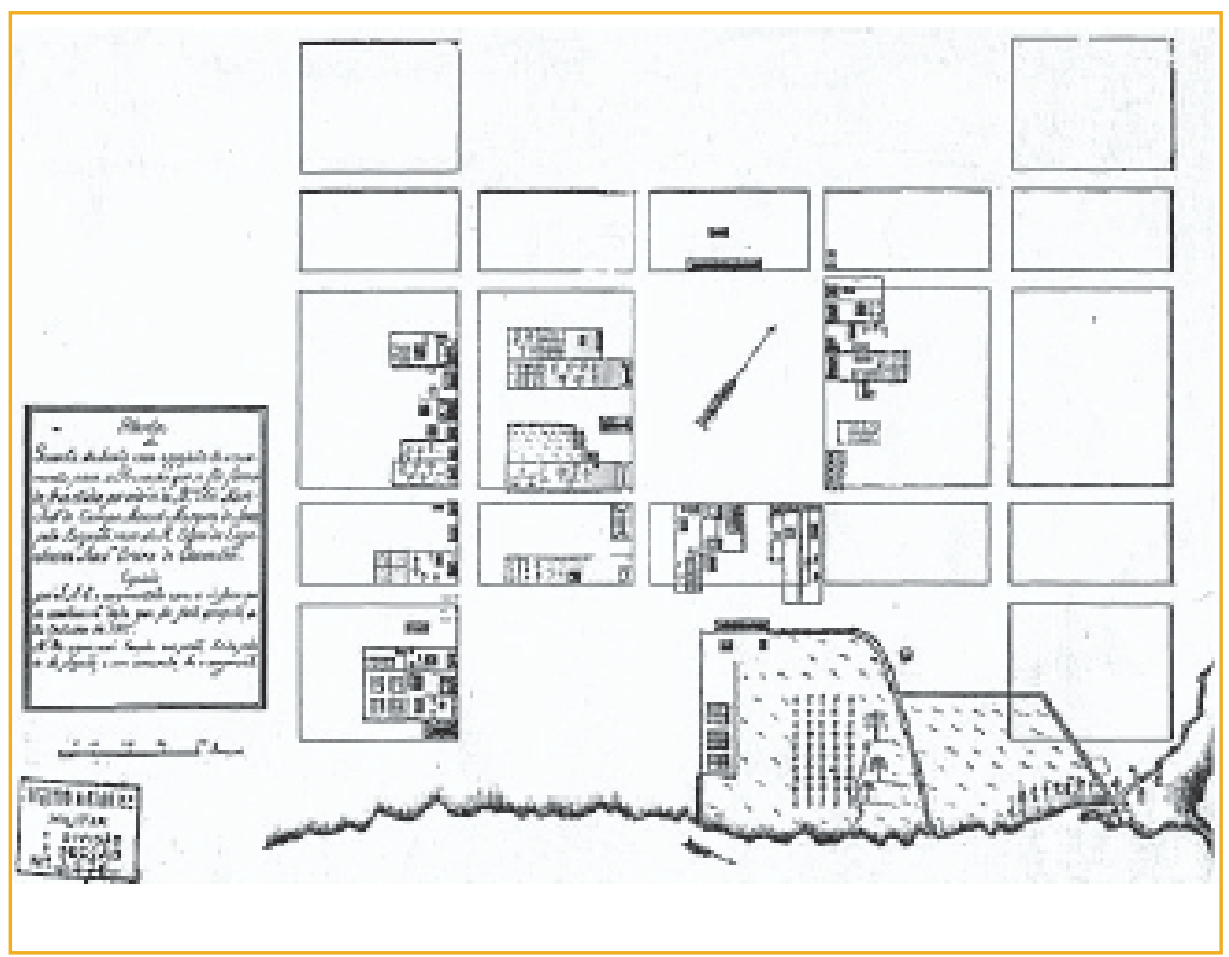

Figure 2. Serrito Guard (Jaguarão), 1916.

Source: Military History Archive, Lisbon, Cartography.

In particular, the city experienced the peak of its economic development between the seventeenth and nineteenth centuries via rural production in plots of land distributed in colonial Brazil(sesmarias).This made possible the increase of services and commercial activities into the city, as well as investments in its historic urban nucleus (actually preserved by IPHAN-Instituto do Patrimônio Histórico e Artístico Nacional-Institute of NationalHistorical and Artistic Heritage). Unlike other cities 
in Rio Grande do Sul, however, Jaguarão did not specialize incharque(jerked beef) production, maintaining minimal diversified production, essentially focused on grazing (Martins, 2002).

According to historical literature, the Brazilian-Uruguayan border oscillated its position until the early $20^{\text {th }}$ century, justifying military presence in both countries. The International Bridge and the railroad construction allowed the connection between Southern Brazil and Montevideo's harbor in the 1930s. However, the trade rise, as well as cargo transportation relations between countries -allied to a more stable political condition -assured the institutional focus for migratory and customs installations instead of military defense.

The socioeconomic relationship between the twin cities, investigated here, dates back to a time when the first settlements were formed in the southern region, and their roots were still apparent in the $17^{\text {th }}$ century. In the case of Jaguarão and Rio Branco, both the planning and the morphological development of these cities were determined by the military processes in what was a strategically important zone to the subjects of national sovereignty. Its morphology is still adapted today according to the institutional perspective of interest. In this case: migration, trade and customs supervision.

\section{CRITERIA AND METHODOLOGICAL APPROACH}

The following analysis results from field work developed in December 2016 and seeks to present the local territorial dynamics of the twin cities of Jaguarão and Rio Branco. In order to do so, we consider the idea that, in these realities, the defense and security systems are linked to productive activities of the tertiary sector, both in the lower and the upper circuits. These sets of systems are territory structuring factors and allow the identification of dynamics in the integration of these cities. The analyses are based on the following criteria:

- Defense and security: this is the most specific criterion in border city analysis, in particular, twin cities. The relevance of this criterion is based on the historical records of the formation of these settlements, mainly from Jaguarão, as a Brazilian military base. At the same time, the permanence of 
this activity is verified essentially through defensive and protective facilities, whether in the economic or geopolitical field;

- Productive activities: condition of existing cities; tertiary production of each locality which clarifies their functionality, as well as suggesting evidence of their historical, economic and social formation.

Based on these criteria, we discuss the forms of city organization located on border lines. Methodologically, the information contained in the thematic maps was produced according to fieldwork observations made in December 2016. In order to produce thematic maps we used, as cartographic base, Brazilian and Uruguayan road shape files, available on the Open Street Maps site. We also considered, as geopolitical limits, IBGE's (Instituto Brasileiro de Economia e Estatística-Brazilian Institute of Economics and Statistics) criteria.

The analysis of defense structures in this research is based on three types of installations, according to legal attributions constitutionally granted by the Brazilian Constitution of 1988 (Brasil,1988). They are, as follows:

- Essentially defensive: areas and military stations. These are structures made for national sovereignty maintenance. On the Brazilian side, there is the $12^{\text {th }}$ Mechanized Cavalry Regiment; on the Uruguayan side, the $2^{\text {nd }}$ Cavalry Brigade, from Cerro Largo;

- Control and civil administration (public security): police stations (civil, military and federal, for Brazil, and Jefaturade Policía, for Uruguay). In the case of Brazil, the jurisprudence goes beyond national civil interests and affects federal interests as well (National Government, Federal police);

- Economic control and management: customs, dry ports and Federal Tax Inspection Stations. As Dorfman (2013) notes: there is a shifting of military political focus to a restraint dialogue on cross-border crime, notably those involving trade practices of legal and illegal products. From this perspective, the inspection and taxation institutions are increasing, as well as facilities that support the flow of international cargoes - dry ports. 


\section{DISTRIBUTION AND TERRITORIAL IMPLICATIONS OF DEFENSE STATION}

Fieldwork observations indicate distinct territorial strategies between military installations and contemporary security and tribute structures. While military installations tend to be located in strategic territorial points for site control, notably near the border, customs facilities are located in the main accesses (or exits) of both cities, in order to facilitate the vicinal traffic among urban centers. Such a change in strategy may be explained by a brief review of the institutions of customs, a more detailed analysis of the Brazilian case, in view of the greater complexity of the agencies, and an analysis of the agreements of border cooperation in MERCOSUR 2 .

Because of Federal Police jurisprudence in acts of international crime repression, customs practice and immigration control generally occur in an integrated border manner. However, the Federal Tax Inspection Station function is to administer the duties of the Union, as well as to prevent and combat illegal international trade acts.

In the twin cities under study, border control has taken place under ACI(Área de Controle Integrado-Integrated Control Area) regiment of Jaguarão since 2005. Customs and dry ports are part of this complex. ACI is the result of negotiations within MERCOSUR and aims to promote the so called simplified customs transit among its member States, which has generated a secondary transit zone (free zone) on the Jaguarão-Rio Branco border, without any ostensive supervision. There is a partial ACI station in this territory although only the part relating to the modality of loads has been installed. This seems to reinforce the theory of a change in protective axis on border zones between military field and capital.

From the point of view of people control, however, there is no effective immigration control, only the voluntary register of migrants. While on the Brazilian side, the Federal Police station is located far from the ACI, in Uruguay the immigration control is made at its customs post (Figure 3). Neither site, however, performs ostensive surveillance. The development of cities based on military camps in the past has facilitated the current international trade monitoring. Both cities are established as urban settlements without many interurban or regional road

\footnotetext{
2 Customs is understood as an official office that controls the flow of goods, as well as their taxation. There are big differences between customs and border Police that should be observed. With regards to the function performance of the latter, the Brazilian Constitution of 1988 defines Federal Police as a permanent body with a career structure in its 144th article.
} 


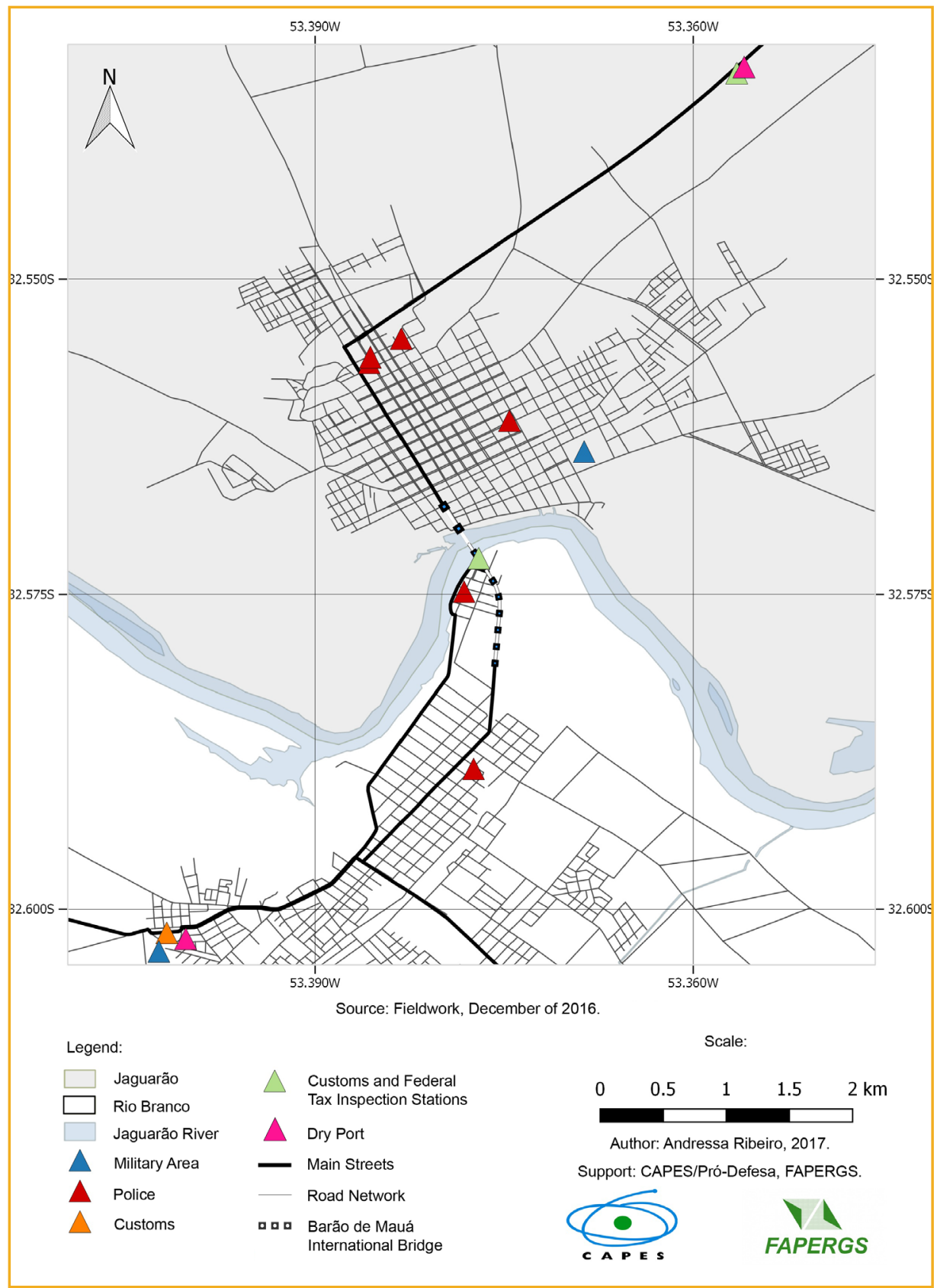

Figure 3:- Military defense equipment location in Rio Branco-Jaguarão Source: Fieldwork, December 2016. 
connections, even with their different strategies of planning and development. It seems that this situation tends to facilitate the control in matters of traffic and smuggling (despite the existence of different escape routes with the flow of goods).

It is also worth mentioning that there is a main circulation axis between the two countries, at each extremity of which is the customs station under public institutions management. In these spaces, the federal sphere is represented in local territory, with police agencies and army representations from both countries.

\section{WHERE AND HOW CAPITAL CIRCULATES IN TWIN CITIES}

This research chose the structures with the greatest capital flow that participate in the upper circuit of urban economy and are present in the twin cities to show the territorial impacts of its investments and implantation.

In the scope of productive activities, although Jaguarão and Rio Branco still maintain their economic base linked to cattle and agrarian activities, both have changed since the installation of the free shops sector in Rio Branco. According to Dorfman (2007), the first free-zone stores in this region were established in Rivera and Chuy in 1986. This followed the creation of a border free zone regime defined by a Uruguayan government law and spread to other border cities, particularly since the year 2000, as was the case of Rio Branco (2002). The implementation of these stores has promoted the increase of urban land value, besides altering the economic dynamics of the territories and the flow of people. The main result was the expulsion of former local residents as well as morphological changes in the cities, especially Rio Branco, through use and building substitution.

The franchises installation close to the International Bridge is spatially based on historical factors, but also reflects the fragmentation of its use with the surrounding community. The urban material of Rio Branco is divided between the free-trade region and the densest settlement region, where most of the local population lives. As previously seen, the explanation for this fragmented space was the floodplain of Jaguarão River, which directly affects the lands near its banks, as in the region of free shops. Although this area has historically been destined to trade activities, today it is subject to intense land valuation and population transfer. According to Mazzei (2012, p. 63): 
esos cambios se procesan en el contexto más amplio de despoblamiento residencial en la zona comercial cuyas viviendas particulares son vendidas a precios elevados y sustituidas por los comercios de free shops.

This perspective is consistent with what has been verified in the fieldwork mappings, in which it is noted that formal and informal trade areas coexist together in the two cities. However, it should be noted that there are different repercussions in each country. Although Jaguarão has already been approved by municipal law for the installation of free shops, the city still does not have any tax free stores ${ }^{3}$. Its link with Uruguay has been to support tourist activities, especially in hotel and gastronomy sectors.

Similar to intraurban relations, the presence of free shops changes the relationship between rural and urban populations. Migrations experienced mainly in the Uruguayan territory are due to free shops offering a new job opportunity for young people with low qualification in the region. These tertiary activities represent an alternative income and city dynamization, even though the distant economic situation between Brazil and Uruguay confers a fairly marked degree of dependence on economic stability and on fluctuations in the exchange rate of the dollar, the currency of imported product commercialization. All these things confer economic distance between Brazilian and Uruguayan realities (Mazzei, 2012).

It was also observed that the formal and informal trade zone locations in both cities formed part of the lower circuit. This strong presence of small commerce and street vendors in the sector reveals the significant interaction between upper and lower circuits of the economy, located at the bridge base, near the free shops sector. These facilities tend to focus on Uruguay Street (connection between the BR-116 and the International Bridge) and around the Public Market. It means these areas are clearly defined as mixed use and easily accessible to tourists. From this perspective, the increase in new activities in Jaguarão is much more integrated and urban planned than in Rio Branco.

The industrial sector is another important area in the two cities (mainly focused on agricultural production). In the first analysis (Figure 4), the industrial and

\footnotetext{
3 Brazil approved Law 12,723 in 2012, regulating the installation of stores in its border cities. Its effectiveness also depends on the approval of municipal legislation specific to each locality, in addition to releases from the Federal Revenue Service.
} 


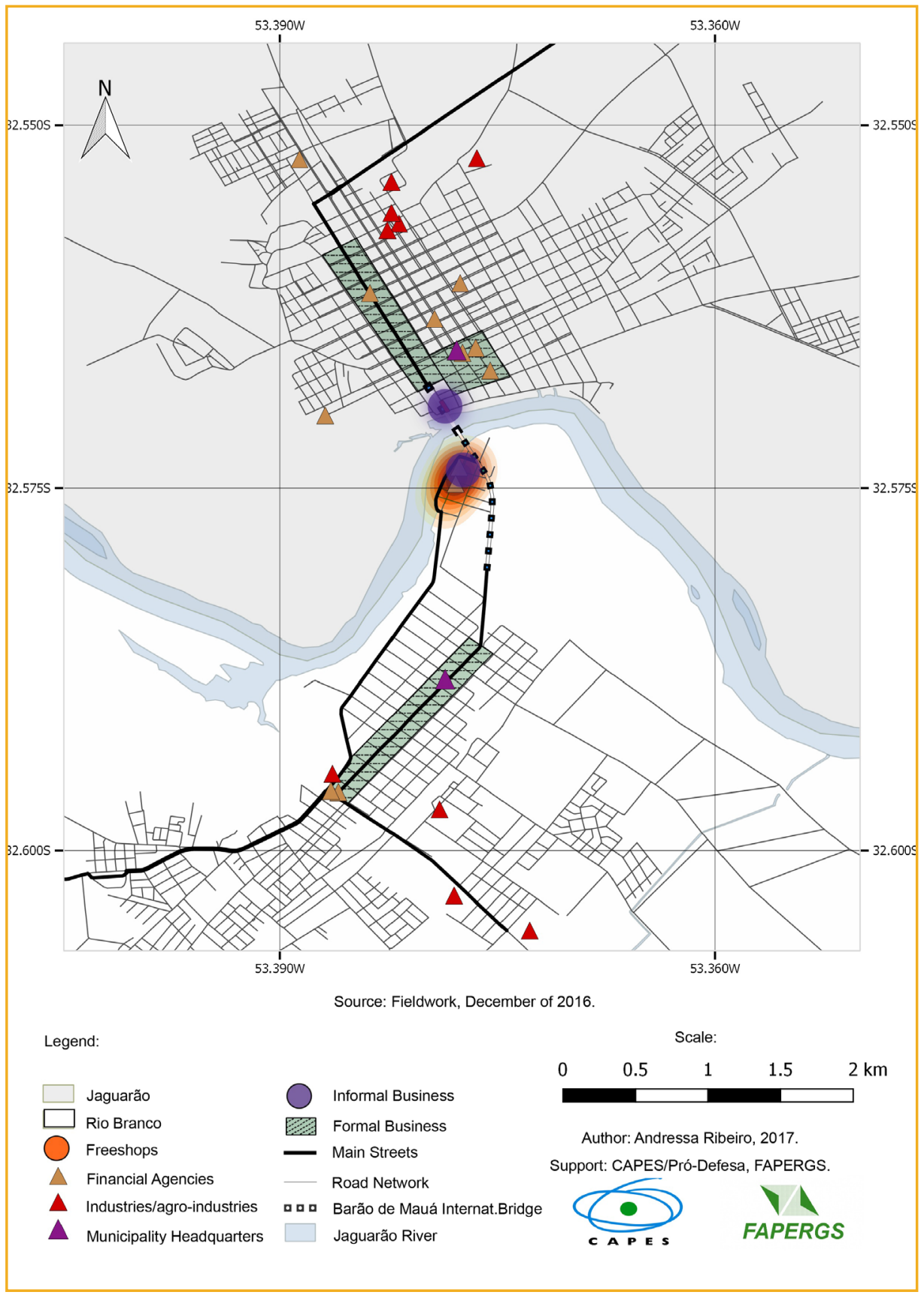

Figure 4. Location of main economic activities, with commercial center limits between Jaguarão and Rio Branco

Source: Fieldwork, December 2016. 
agricultural enterprises are situated within the limits of urban areas, moving the industrial production away from commercial centers, but close enough to use their infrastructure. In Jaguarão, however, the concentration of industries was verified as being on the limit of their urban area. In both cases there is a clear proximity to the main road and rail routes.

The first industrial structures in Jaguarão were concentrated near the port, located on the banks of Jaguarão river to facilitate transportation. They were also close to the commercial center of the old city, near the public market, the fairground and several official services. In fact, this central implantation was not only in close proximity to the urban nucleus, but also to the centrality of the activities performed there. It was also close to superficial urbanistic regulation that, at the time, provided only controls against noise and gas (Martins, 2002).

Fieldwork observations, however, reveal that these old structures now play a different role, mainly designed for a small third sector. This change in Jaguaráo industrial site may have occurred because of processes of soil valorization, as well as the intensification of relations with Uruguay through the International Bridge, by the middle of the $20^{\text {th }}$ century. More rigorous urbanistic regulations such as the activities regime also contributed to this. High investments made by the Brazilian Federal Government in its road network, increasingly in the 1950s, encouraged the substitution of other transportation modes, such as waterways and railways.

The changes of use and occupation on the river banks enabled the development of new economic activities, linked to either the upper or lower circuits of the economy. As Jaguarão limits its expansion and mixed renewal area, it also reassures its territory facing recent commercial pressures, whether formal or informal. The same cannot be said for Rio Branco, where there has even been a lack of support for structures of social and community assistance.

\section{FINAL CONSIDERATIONS}

The morphological constitution of the twin cities on the Brazilian-Uruguayan border confers specificities based on Rio de la Plata Basin culture, present in the Region, especially where social and economic interactions are dynamized by the presence of free shops. 
Historical references demonstrate: a) the relation between site and situation that each city establishes with the river: Jaguarão extends along the edges of the river, while Rio Branco is set back in a situation of central preservation; b) the urban orthogonal layout, which obeys the precepts of the Portuguese military defense engineering (in Jaguarão) and Spanish (in Rio Branco) from the time they were created. This urban space organization tells the story of former confrontations between Brazil and Uruguay, in which these former occupations passed from military camps to cities in the $19^{\text {th }}$ century.

There is also a spatial fragmentation between the two occupations, caused not only by the presence of the river, but also by the historically marked differences caused by the need for defense between the Uruguayan settlement, the free trade sector and the more spatially dynamic Brazilian side. This fragmentation is attenuated by the synaptic connections obtained through the bridge implantation and the road that reaches the city of Rio Branco.

From the point of view of military defense, there is no clear understanding of any rigorous institutional surveillance in the regional secondary and tertiary activities, even though there are cultural and economic links between the countries. In relation to productive activities, the network flow becomes more concentrated and intense near the bridge, where, in addition to free shops, informal commerceis found. There is no difficulty in accessing cities or free shops at this point, as control spaces are located just outside the cities. There are also the defense and security facilities which are much more attentive to goods circulation than to people.

The twin cities in this research prove more than ever that objects of interscalar articulation participate in complex processes of economic integration, although with little visibility in their national territories. They are areas that not only inherit their own local histories, but act as testimonies of daily disputes between global capital. 
Brasil. (2005). Proposta de Reestruturação do Programa de Desenvolvimento da Faixa de Fronteira. Brasília: Ministério da Integração Nacional/Secretaria de Programas Regionais/ Programa de Desenvolvimento da Faixa de Fronteira.

Brasill. (2012a). Política Nacional de Defesa. Brasília: Ministério da Defesa.

Brasil. (2012b). Lei 12.723, de 9 de outubro de 2012. Brasília: Casa Civil. Retrieved from: <http://www.planalto.gov.br/ccivil_03/_Ato2011-2014/2012/Lei/L12723.htm>

Brasill. (1988). Constituição da República Federativa do Brasil. Brasília: Senado Federal. Coordenação de Edições Técnicas. 496 p.

Dorfman, A. (2007). Fronteira e contrabando em Santana do Livramento (BR) - Rivera (UY), in II COLÓQUIO NACIONAL DO NEER.Salvador. Retrieved from <http:/ /www.neer. com.br/anais/NEER2/Trabalhos NEER/Ordemalfabetica/Microsoft\%20Word\%20-\%20 AdrianaDorfman.ED3III.pdf>

Fagundes, F. C. R. (2016). Entre Segurança e Defesa: o Poder de Polícia das Forças Armadas na Faixa de Fronteira, in Simpósio de Pós-Graduação em Relações Internacionais do Programa San Tiago Dantas (UNESP, UNICAMP, PUC-SP). São Paulo.

Instituto do Patrimônio Histórico e Artístico Nacional (IPHAN). (s/d). Jaguarão (RS).

Retrieved from <http://portal.iphan.gov.br/pagina/detalhes/1536/>

Instituto Brasileiro de Greografia e Estatística (IBGE). (2013). Atlas do censo demográfico 2010. Rio de Janeiro: IBGE. Retrieved from <http:/ / biblioteca.ibge.gov.br/index.php/bibliotecacatalogo?view=detalhes\&amp;id=264529>

Instituto Brasilleiro de Geografia e Estatística (IBGE). (2010). Censo Demográfico 2010. Rio de Janeiro: IBGE.

Martins, R. D. (2002). A ocupação do espaço na fronteira Brasil-Uruguay: a construção da cidade de Jaguarão. Barcelona: Departament de Composició Arquitectònica, Universitat Politècnica de Catalunya.

Machado, L. O. (2010). Cidades na fronteira internacional: conceitos e tipologia. In A. Nunes et al. (ed). Dilemas e diálogos platinos: fronteiras. Dourados: Ed. UFGD.

Mazzei, E. (2012). La Frontera en cifras. Melo: Universidad de la Republica Uruguay/Centro de Estudios de la Frontera.

Organização dos Estados Americanos (OEA). (2003). Declaração sobre Segurança nas Américas. Mexico: OEA.

Pucci, A. S. (2010). Estatuto da Fronteira Brasil-Uruguai. Brasília: FUNAG.

Rüickert, A. A. and Dietz, C. (2013). Integração regional, a região transfronteiriça da Bacia do Rio da Prata e os projetos de infraestruturas de conexão. Confins, 17, p. 1-34. 
Saint-Pierre, H. L. (2011). Defesa ou Segurança? Reflexões em torno de conceitos e ideologias,. Contexto Internacional 33(2), 407-433.

Santos, M. (2006). A Natureza do Espaço: Técnica e Tempo, Razão e Emoção. 4. ed. São Paulo: Editora da Universidade de São Paulo.

Santos, M. (2008). O espaço dividido: os dois circuitos da economia urbana dos países subdesenvolvidos. São Paulo: Editora da Universidade de São Paulo.

Sillveira, M. L. (2007). Crises e Paradoxos da Cidade Contemporânea: os Circuitos da Economia Urbana. In Anais do X SIMPURB, Florianópolis.

Uruguayan Demographic Census. (2011). Instituto Nacional de Estadística (INE). 

Part II

\section{Territorial policies applied to the borders of La Plata Basin}





\section{IIRSA AND THE ROLE ASSIGNED TO THE LA PLATA BASIN REGION IN SOUTH AMERICAN PHYSICAL INTEGRATION}

\section{Eduarda Figueiredo Scheibe}

\section{ABSTRACT}

At the end of 2000, in Brasilia, the twelve sovereign countries of South America launched a plan for the regional infrastructure integration that currently guides the actions of the South American Council of Infrastructure and Planning of UNASUR. The aim of the initiative is to connect these countries' transport, communications and energy networks across the subcontinent. The study of IIRSA Integration and Development Hubs, however, shows that there is a significant concentration of groups of projects in the cross-border region of $\mathrm{La}$ Plata Basin. Because to each IIRSA Hub and group of projects specific integration objectives and characteristicsare assigned, it is possible to infer from this overlap of proposals for territorial interventions with South American objectives that this cross-border region has a central role in the integration of the whole macroregion. In this sense, this article intends to analyze the type of physical integration promoted from the 2000s in the La Plata Basin by South American national governments, where the decision-making process related to IIRSA continues to be centralized. Furthermore, to the better understanding of the issues hereby presented, the historical background on the subregional physical integration initiatives will be also considered.

KEYWORDS Integration of the Regional Infrastructure of South America, physical integration strategy, the La Plata Basin. 
The initiative for IIRSA ${ }^{1}$ (Integración de la Infraestructura Regional Suramericana - Integration of the Regional Infrastructure of South America) as suggested by its name, presents a common strategy for the subcontinent's physical integration compiling projects in the transport, communications, and energy sectors within the area of influence of ten Integration and Development Hubs. Four of these Hubs overlap the La Plata Basin region.

The present study seeks to clarify the role of the mesoregion to the South American physical integration strategy. In order to answer this question, it explains some of the regional tools IIRSA provides to further understand the meaning of this concentration of projects in this part of South America. It analyzes the Hubs overlapping the La Plata Basin and its most immediate surroundings. Because the goal is also to identify any particularities to the mesoregion regarding the twelvestate plan, a comparative examination of all Hubs was conducted, and its results are hereby explored. This article also assesses the historical background on physical integration initiatives involving the La Plata Basin countries, especially as from the institutionalization of the La Plata Basin System, in 1969.

Despite the fact that some field works are briefly mentioned along the text, no comprehensive field work was conducted specifically to the objective of this study, the reason why the La Plata Basin region interests or strategies on regional development, those emanated from the mesoregion, are not subject to the following sections bellow. The IIRSA literature and the literature produced to analyze it from a critical point of view have been, nevertheless, largely explored a means to highlight the national and South American interests assigned to the region in case.

\section{IIRSA HUBS: THE INTEGRATION OF REGIONAL INFRASTRUCTURE IN SOUTH AMERICA}

By the end of the year 2000, representatives of the twelve sovereign countries of South America reunited in Brasilia agreed to launch a plan for integrating the regional infrastructure in the subcontinent. The plan, which would be known as

1 The acronym IIRSA is used in both Spanish and Portuguese languages. 
IIRSA, was certainly not the first to highlight the importance of physical connections for the achievement of regional integration goals. Previous commitments were made aiming to connect infrastructure networks in smaller regions or focusing in only one sector of infrastructure at a time. The innovation of IIRSA relies on proposing, on a South American scale, the connection of transport, energy and telecommunications networks, under the same initiative. Since 2010, IIRSA provides the guidelines to the South American Council of Infrastructure and Planning of UNASUR, the Union of South American States.

The most outstanding feature of the initiative, highlighted in the official documents as in the critical evaluations by academia and non-governmental organizations, is precisely IIRSA territorial planning strategy. The infrastructure projects are organized in Infrastructure and Development Hubs, while ech Hub represents, in practice, a section of South American territory and a specific dynamic of actual or potential integration, as specific objectives on physical integration are attributed particularly to each area of influence. This choice of territorial planning aims to increase the efficiency of investments made in infrastructure throughout the subcontinent, favoring the construction of connections between territorial nodes previously identified as economically dynamic.

In this sense, the IIRSA plan is not guided by, although it is not opposed to, the rationale of enabling new socioeconomic dynamics. It is, above all, designed to reduce the constraints on economic activities already underway and often playing a preponderant role in national economies. It is also in this sense that many of the critics over IIRSA point out that the architecture of Hubs prioritizes structures that contribute to maximizing development strategies based on extractive export economic activities (Carrion \& Paim, 2006; Ceceña, Aguilar \& Motto, 2007; Dijk, 2008; Svampa, 2011, among others).

The concept of integration and development Hubs had also been previously applied, but at national level. In Brazil, for example, similar Hubs had been proposed in 1996, within the scope of the government program Brasil em Ação. If, on one hand, these same Hubs were considered inefficient by scholars such as economist T. B. Araújo (2000), who considers them to be instruments that only increase inequalities between the different Brazilian regions; on the other hand, a study coordinated by E. Batista da Silva (1997), also from Brazil, which similarly used the notion of Hubs for Latin American integration, had a clear influence on the first version of the IIRSA plan (Inter-American Development Bank, 2000). 
Despite criticisms, according to the definition of documents published by IIRSA, the concept of Integration and Development Hubs goes beyond the one of transport corridors or of infrastructure networks. The IIRSA Hubs represent, in fact, the spaces articulated by these corridors and networks, "involving specific natural resources, human settlements, production areas and logistic services" (IIRSA, 2011, p. 8). The projects enrolled by IIRSA's portfolio are organized in ten Hubs and are aimed at assisting the development of their entire area of influence (see Figure 1).

As an aspect less explored by the literature about IIRSA, each Hub is further divided into groups of projects with smaller areas of influence and to which, as for the Hubs, specific goals are assigned. The purpose of this subdivision is to facilitate the negotiations and the planning of each project. This way, only the representatives of the countries and, sometimes, of the sub-national administrative units whose territories are most directly affected by the planned structures take part in the negotiations of each group of projects.

Case studies demonstrate that local authorities and interest groups' capacity for interference varies according to the type and location of the project ${ }^{2}$. In addition, the negotiations and decision-making process through which IIRSA materializes are largely centralized by national governments. Cross-border infrastructures are matters of competence for the representatives of so-called national interests, with selective preponderance over sub-national and sub-regional interests.

However, the map of IIRSA projects, an innovation of the initiative that is often underestimated in terms of its repercussions, allows the visualization and highlights the various scales of the integration process, in addition to the multinational one. Individual infrastructure projects - each stretch of road, each power transmission line or fiber optic cable connection - continue to be classified as national or binational projects, but are to be interpreted as part of a common South American physical connection strategy. The IIRSA portfolio of projects is recognized by all twelve States as indispensable for the success of regionalist goals in South America. At the same time, the planning of those as part of integration Hubs and smaller groups of projects draws attention to the fact that each bridge or stretch of road has parallel repercussions at other territorial levels.

2 The author has conducted interviews with local authorities in border areas between Brazil and Uruguay (in 2016) and Brazil and Peru (in 2017). Furthermore, other studies demonstrate the potential gap between local authorities along the Brazilian Borderland Strip and central-national authorities, such as those by A. R. da Silva (2011) and A. Rückert \& C. Carneiro Filho (2015). 
In addition, the spatial organization of IIRSA projects grants the possibility of capturing the different stages of connection and integration conditions observable in the various sub-regions of South America, since diagnoses were published and updated for each Hub of integration. The first few versions of those studies, which guided the definition of the priorities for each Hub from the initial years of IIRSA, were called "Business Visions". Currently these documents are named "Socioeconomic and environmental characterization". We can consider these publications as part of IIRSA's intangible dimension, together with the normative harmonization processes for the effective operation of the projected regional infrastructure networks.

The preparation of characterization studies is coordinated by the Institute for Integration of Latin America and the Caribbean of the Inter-American Development Bank (IDB), which hosts the Institutional Secretariat of IIRSA ${ }^{3}$. They report on the economic and social situation of each Hub's area of influence, as well as on their geographic characteristics and the main productive activities of those zones, with a clear focus on export-oriented activities, although they also intend to clarify the possibilities of intra-zone trade, in this case, intra-Hub trade.

It is important to notice that, because of the moment of its launch and the centralized of the decision-making process, at national level, it is possible to affirm that IIRSA had its continuity assured, and development conducted, mainly by national leaders who identified their government programs with leftist ideals. Regarding to the South American regional integration process, this translated into a discourse of priority approximation among South American countries in order to achieve greater autonomy of action on international affairs.

Notwithstanding, a brief review of the critical literature on IIRSA suggests that the plan would serve, to a large extent, the objectives of extra-regional international actors. Given that the period immediately preceding the launch of the initiative in 2000 was strongly marked by the discussions on the implementation of the Free Trade Area of the Americas, under the leadership of the United States, many of the initial analyzes interpreted the projected connections as intended to lay the material foundations precisely for the implementation of the neo-liberal contoured Pan-

3 The Institute for Integration of Latin America and the Caribbean (INTAL) is also responsible for compiling and coordinating researches on the development of common methodologies for the implementation of infrastructure projects, which cover topics such as environmental sustainability, logistics integration and territorial development from the point of view of local populations. Although the application of these methodologies is not mandatory, they represent an important advance in the subject of South American physical integration. 
American agreement - for instance, as seen in G. Carvalho (2003), M. C. Carrion and E. Paim (2006) and A. E. Ceceña, P. Aguilar and C. Motto, (2007).

These authors point out, unlike the most recent publications by the initiative itself, that the main objective of IIRSA would be related primarily to the exportation of South American products, mostly of commodities. The goals described for each of the integration Hubs and groups of projects do, in fact, highlight the export sectors as aimed toward overseas markets. As seen, the very organization of integration in Hubs is justified by the need to prioritize spaces in which there are cross-border dynamics that can attract financing for the construction of additional physical connections.

If, on one hand, this logic is based on the fact that foreign trade is an important part of the gross domestic product of all the countries that make up the South American bloc, on the other, it is possible to identify, through analysis of the same documents, a concentration of investments in infrastructure that benefit only few but large economic activities such as iron and copper ore mining industries, oil exploitation and soy cultivation (Scheibe $\&$ Rückert, 2014). More than that, the discourse of socioeconomic development as linked to the development of these same sectors often overshadows the objective of South American integration and autonomy itself, as it does for the sub-regions within the subcontinent ${ }^{4}$.

The following image (Figure 1) presents the ten Integration and Development Hubs of IIRSA. The next sections, however, make reference to only nine of these Hubs, as the Southern Andean Hub has, so far, no projects attributed to it. It continues to be portrayed on IIRSA maps, but there are no further documents on the subject. The image bellow also depicts the overlap of four Hubs around the La Plata Basin region area.

For the purposes of this work, 249 out of the 562 IIRSA projects were considered as located or immediately connected to the La Plata Basin region. As for the limits of the mesoregion, the area of influence of the ParaguayParaná Waterway Hub along with to the Atlantic coastal portion of the MERCOSUR-Chile Hub were established as reference. This decision was made based on the fact that, although there is no consensus over the exact limits of the La Plata Basin region, the river basin plays an important role to its identity, as does the polarization effect exerted by the Southeast region of Brazil.

4 This statement is particularly valid for the process of physical integration, because regionalism and regional relations in South America have developed on a broader basis than the commercial one since, at least, the beginning of the twenty-first century. 


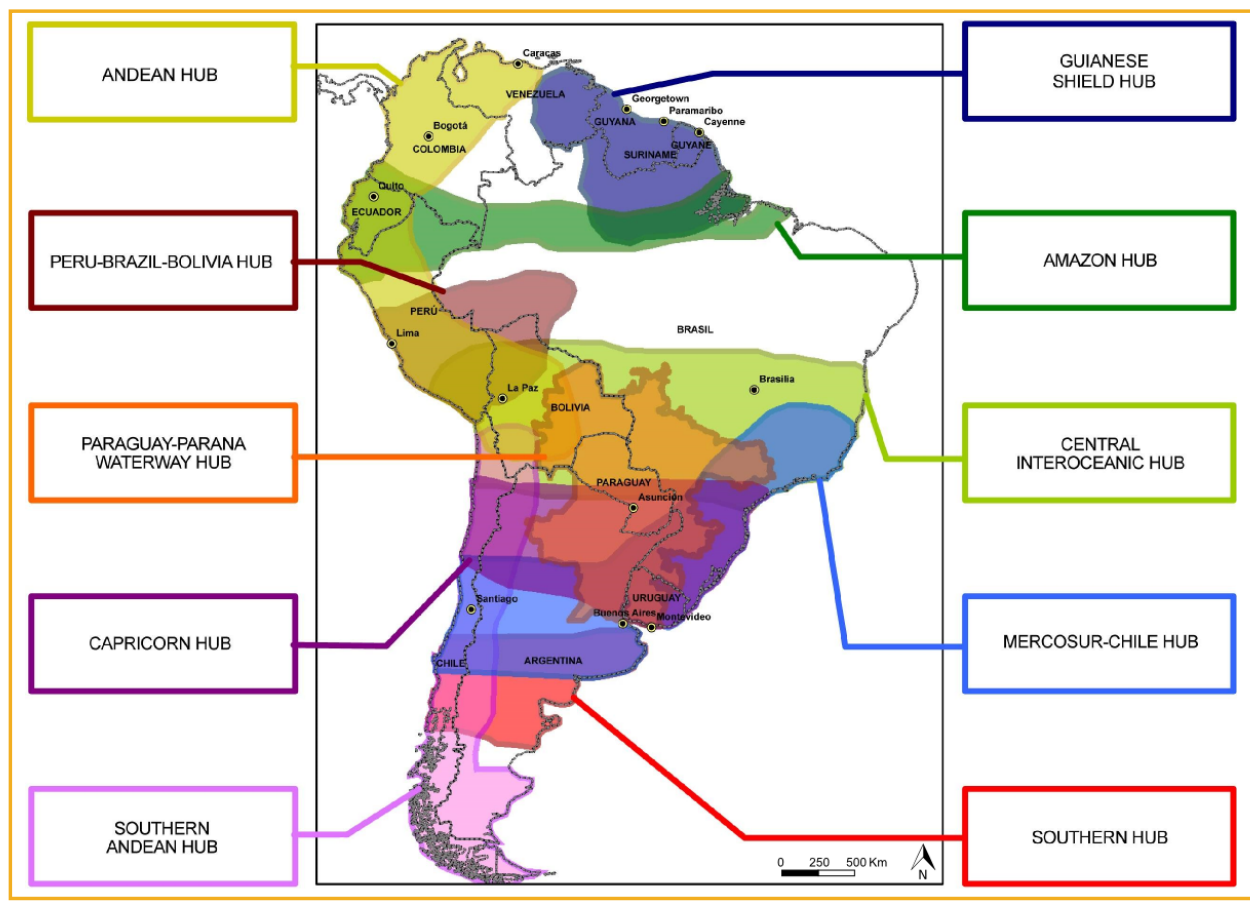

Figure I. IIRSA Integration and Development Hubs (IIRSA, 2011, p. 66)

\section{LA PLATA BASIN REGION AS THE AREA OF INFLUENCE OF EMERGING AND NON-EMERGING HUBS}

Certainly, analyzing the incidence of IIRSA in the La Plata Basin region is not limited to studying only the Hubs that pass through and overlap this particular region; not only because of the very nature of physical integration, its objectives and its architecture, which precisely predict the connection between the different mesoregions of the subcontinent. But above all, because, once the objective is to understand how IIRSA affects this region differently than it does to other parts of the subcontinent, it is essential that a comparative analysis be carried out between the overlapping Hubs in the La Plata Basin and those who do not cross this area.

The Project Portfolio for the year of 2009 informs the possibility of classifying the Integration and Development Hubs in two distinct groups. On one side 
there would be the two Hubs that have their identity more directly linked to the processes of regional integration Andean Community of Nations and Southern Common Market, the Andean and MERCOSUR-Chile Hubs, respectively. These two Hubs are characterized by "high concentrations of human settlements and clear patterns of regional trade and physical integration" (IIRSA, 2009, p. 15) and thus differentiated from the other Hubs, named the emerging Hubs. In the group of the emergent Hubs would be those characterized by the unfulfilled potential of integration due to "physical restrictions".

Even though the expression "physical restrictions" is no further explained, there are at least two possibilities for its interpretation. The first is related to characteristics linked to the physical constitution of the Hubs' area of influence, to those aspects that define the use of the territory to such a point that can impose barriers to certain forms of appropriation. The second concerns the efficiency of built structures for the appropriation of these areas while bearing in mind the purposes attributed to them, such as, restrictions to the particular goals of Hubs and development.

However, due to the overlap of two types of Hubs over the area that we understand here as the La Plata Basin region, the question of how should this region be analyzed regarding physical integration current strategy remains unanswered. In addition to a significant part of the MERCOSUR-Chile Hub, the ParaguayParaná Waterway Hub and parts of the Capricorn and Central Interoceanic Hubs coexist in this area. The latter three are identified as emerging Hubs as much as the Southern and the Guyanese Shield Hubs, for example.

Provided that the integration potential of a Hub is defined from the characteristics of the territory over which they exert their influence, what does the overlap of three emerging Hubs and the MERCOSUR-Chile Hub reveal about the role of the La Plata Basin for IIRSA strategy? At the same time, what characteristics of the La Plata Basin differentiate these four Hubs of integration from the other Hubs part of IIRSA?

In order to answer these questions, a two-phase study was carried out. Firstly, the documents of characterization of the area of influence and the integration objectives for each Hub were examined. This stage allowed for better understanding of the four Hubs with influence over the La Plata Basin region. Secondly, the data on the types of projects that constitute the nine IIRSA Hubs were reorganized in order to compare them according to variables selected from the outcomes of the first stage of analysis. The two steps are briefly described below. 


\section{CHARACTERIZATION OF IIRSA HUBS OVERLAPPING THE LA PLATA BASIN REGION ${ }^{5}$}

\section{PARAGUAY-PARANÁ WATERWAY HUB}

The Paraguay-Paraná Waterway Hub, not surprisingly, is the Hub whose area of influence corresponds in greater proportion to what we identify as the La Plata Basin region. All of the 84 IIRSA projects that it comprises are located within the region's territory. The main goal set for this Hub is to consolidate the waterway alternative for the cargo transportation from and among border countries. However, it is important to note that the notion of the La Plata Basin region exceeds the concept of hydrographic basin and also the one of waterway, so it would be a mistake to assume that this Hub represents more the situation of the region than the others listed here.

International borders here are mainly formed by the rivers of the La Plata basin, and thus constrain the international flow by land. Cross-border exchanges among these countries, therefore, depend on adequate infrastructure for the transposition of such constraints, such as bridges, which tend to concentrate the flow of land vehicles in a reduced number of spots. This Hub, however, focuses on the use of the waterways, while land transport structures for cross-border connection are contemplated by the other Hubs that overlap in this region.

Nevertheless, preventing overload of the land routes to optimize intra-regional trade is certainly not the only goal of the Waterway Hub. It is often emphasized in the description of its projects that the river system offers an important alternative for extra-regional outflow of Paraguayan and Bolivian products, for it would provide the two countries with access to the Atlantic Ocean, which is also true for some riverine zones of Argentina, Brazil and Uruguay. In addition, the affirmation of the Paraguay-Paraná Waterway as a South American interest favors the attraction of financing resources for improvements in ports and storage sites at its margins (Zugaib, 2006), an essential logistic condition for the further development of a

\footnotetext{
5 All data on numbers of IIRSA projects and their phase of completion mentioned in this section have been taken from the project listings on the information system for IIRSA portfolio as available on Aug. 25, 2017 (UNASUR, n.d.).

6 See historical background section for further discussion on this particular subject.
} 
diversity of economic activities, ranging from agricultural production to mineral extraction and advanced industrial activity (Koutoudjian, 2007).

As does A. Schweitzer (2000) when he describes the region studied by this work, this Hub also extends its limits incorporating the Tietê-Paraná Waterway, covered by group of projects number 2. For the Argentinian researcher, the city of São Paulo exerts a polarization effect over the La Plata Basin. The justification for this group of IIRSA projects is similar and highlights the relevance of the navigability conditions of the Tietê River so that it is possible to increase the flow of goods between the two fluvial systems. Soy and iron ore transportation were, from the earliest analysis, the central justification for this extension of the Hub (Koutoudjian, 2007, p. 554).

In addition to the transport sector, communications and energy sectors are covered by the Waterway Hub set of infrastructure projects. Regarding energy resources, the use of Argentine natural gas is on focus, in addition to improvements to the electrical interconnection network in the province of Corrientes. Also, in this respect, the complementarity of the energy projects of this and the other 3 Hubs analyzed below is very clear. Regarding communications, the main goal is to install a common system that makes navigation through Paraguay and Paraná Rivers possible 24 hours a day. Information coordination along the waterway is expected to make it more effective as part of a multimodal transport network.

\section{MERCOSUR-CHILE HUB}

The description by IIRSA documents and the architecture of the projected connections in this Hub's area of influence leads to the conclusion that the first goal of the MERCOSUR-Chile Hub is to provide access to Chilean ports for the four founding members of the Southern Common Market. Consequently, over $70 \%$ of the MERCOSUR-Chile projects are here considered as located in the region of the La Plata Basin, 82 out of 115.

Particularly noteworthy for the transport sector, the area of influence of this Hub can be considered as quite privileged in terms of pre-existing road connections: in a space that corresponds to just over $25 \%$ of the sum of the national territories of the 5 countries crossed by this Hub, $52 \%$ of the total road network of these same territories are concentrated. This is the opposite of what happens, for example, in the case of the Amazon Hub, where only $11 \%$ of the total road network of the Hub-participant countries serve its area of influence, which covers over $50 \%$ of the total territory of Brazil, Colombia, Ecuador and Peru together (IIRSA, 2011). 
The projects aimed at increasing railway transport, particularly, focus on bulk cargoes, which characterize a large part of this area's agricultural production. The growth of this sector of the economy is identified as the main source of pressure on the existing infrastructure (Ospina, 2007) and, therefore, the target of the improvements sought by IIRSA.

Moreover, it is significant that three of the six groups of projects in which this Hub is organized mention among their strategic goals to "make good use of scale and demand conditions in the area to attract public-private partnerships and disseminate the experience to other Hubs (Union of South American Nations, 2016, p. 209, 213 and 217) ${ }^{7}$. This aspect corroborates the idea that the Hub in question could be considered as a laboratory for IIRSA's physical integration policy (Scavini, 2011, p. 45).

The preset work shows, however, that we can also refer to the La Plata Basin region as IIRSA's laboratory: the mesoregion has the characteristics and has been the stage not only for physical integration policy experimenting, but also for regional integration in South America, in the broadest sense of the expression.

\section{CAPRICORN HUB}

The area of influence of the Capricorn Hub does not cover the entire La Plata Basin region, but it does cover an important part of it. In fact, all groups of projects in this Hub refer to the mesoregion directly or indirectly, either with projects physically located in the La Plata Basin, or with projects that aim to connect this region with the Atlantic and Pacific Oceans, especially with the harbor areas of Paranáguá, in Brazil, and Antofagasta, in Chile.

We consider, for the purpose of this study, that 54 of the current 77 projects of the Capricorn Hub are located or allow direct access to the La Plata Basin region - approximately $70 \%$. Though the concentration of investments is far more significant in the region, reaching $90 \%$, it is so largely due to the financing needs foreseen for one project: the duplication of an RN 34 section highway in Argentina, which is estimated to cost more than half of the total sum for all 77 projects.

\footnotetext{
7 The stated goal becomes even more relevant if we consider that attracting private investment in infrastructure in South America is one of the main objectives and one of which is farther from being reached by the regional initiative. Since its launch, only $20 \%$ of projects that had already been executed by the time of conclusion of this study had had private or public-private funding.
} 
Nevertheless, several projects listed by IIRSA project portfolio have an expected value for execution equal to zero, that is, to be determined in the future. This is only one of the evidences by which the variable amount of investments foreseen was not addressed in the present study regarding any of the Hubs ${ }^{8}$.

Once again, the transposition of geographical constraints characteristic to the international borders in this mesoregion is the challenge of the Hub, considering the rivers of the La Plata Basin in the eastern portion and the Andean Cordillera in the western portion. The territorial discontinuity reflecting the physical constitution of this area of influence becomes more apparent after the identification of four sub-regions that guide the strategy of IIRSA to this Hub (Sosa Pinilla, 2007). They are: the Atlantic Coastal Region, composed of the three Brazilian Southern Region states (namely Rio Grande do Sul, Santa Catarina and Paraná); the Northeast Region, composed of Argentinian Northeast, Eastern Paraguay and Mato Grosso do Sul in Brazil; the Northwest Region, which includes the Argentinian Northwest, the West region of Paraguay and the Bolivian portion under the Capricorn Hub area; and, finally, the Pacific Coastal Region, corresponding to the north of Chile. The Capricorn Hub is the only one of all IIRSA Hubs where sub-regions are mentioned and, among the objectives set forth by IIRSA projects, improvements in the internal infrastructure of these Hub's sub-regions are not the focus, but precisely the connection among them.

Regarding the energy sector, the three energy interconnection projects of the Capricorn Hub seek the improvement in power transmission capacity in areas where the existing infrastructure was assessed as overloaded. Complementing the projects of the same type in the Paraguay-Paraná Waterway Hub, these serve the north of Argentina and the eastern region of Paraguay.

The territorial discontinuity characteristic to the Capricorn Hub is reflected also in the diversity of exported products from its area of influence. Networks to export soy and wheat, however, are mentioned most frequently among the economy sectors that would be potential beneficiaries of the projects listed by

8 It should be noted that, as already verified in previously published studies (Scheibe, 2012), the amount of investments should not be considered as a variable for assessments of the IIRSA project portfolio, unless some particular issues are meticulously observed. There is, for instance, large variation in the values of the projects according to the type and conditions in which they are to be executed which has little relation with - or even necessarily related to - the purpose of the structure to be realized. Moreover, it is not unlikely to an amount of investment account only for the cost of viability studies. 
IIRSA portfolio. Unlike copper, exported to overseas markets from Chile, the two aforementioned agricultural products are grown and exported from regions located in the geometric center of the South American subcontinent, precisely in the La Plata Basin region.

\section{CENTRAL INTEROCEANIC HUB}

The Bolivian territory is crucial to the achievement of the main objective of this Hub: the horizontal crossing of the subcontinent from one coast to another. As the eastern and western sections of the Bolivian railway network are disconnected, the integration of the two parts certainly has the potential to contribute to this country's national integration, but the focus described in the project is mainly on reducing the export costs of the central section of South America to other regions of the globe.

The area of influence of Central Interoceanic Hub also crosses the Brazilian, Paraguayan, Chilean and Peruvian territories. Of the Hubs that cross the La Plata Basin, the Central Interoceanic has the lowest proportion of projects located in the region, approximately $46 \%$, but it is still relevant for our analysis.

The railroads are the focus of group of projects number 2 of this Hub, which, despite having all its projects located in Brazil, has the specific objective of increasing the participation of the railway network in the South American regional transport matrix, in addition to connecting Bolivia to Brazilian ports in the Southeast region of this country. In turn, group of projects number 1 highlights the works required for connecting Brazil and Chile across Bolivia and Paraguay, without the need for crossing Argentina, in order to guarantee and reduce transportation costs. It is clear, for the case of this Hub, the polarization exerted on the Basin by the Brazilian Southeast, as by regional nodes located in the northern regions of Chile?

Another important data for the proper characterization of the Interoceanic Hub is the concentration of GDP throughout its area of influence. It shows the inequality between the Brazilian portion and territorial units of the other countries. Brazil is home to $78 \%$ of the area's population and accounts for half of the Hub's territory. The Brazilian portion is, however, responsible for approximately $91 \%$ of Central

9 Improvements in Chilean and Peruvian ports are also among Central Interoceanic Hub projects, but evidently those were not considered as IIRSA projects within the region subject to this study. 
Interoceanic GDP (UNASUR, 2016a). This concentration of the production index suggests that the circulation of Brazilian products and the supply of this area are a central goal for this set of projects.

Equally relevant are the frequently mentioned potential of infrastructure projected on reducing the costs of activities related to the mining and the soy industry. The articulation between the Interoceanic and the Paraguay-Paraná Waterway Hubs builds an alternative for exporting the products of both economic activities and, at the same time, for the case of soy, enables the expansion of economically viable areas for its cultivation (Sosa Pinilla, 2008, p. 140).

However, groups of projects number 2 and 3 state specific goals aimed at producing effects on the La Plata Basin region for non-trade purposes. This is the case, for example, of the tourism-oriented conditions of access improvement to the Pantanal region. Even so, it should be noted that only one project, out of the twelve that make up these two groups, was effectively executed: the Pantanal Railroad. It was inaugurated in 2009, according to the project file in the IIRSA database (UNASUR, n.d.), but operated only until 2015 (Malagolini, 2016).

\section{THE LA PLATA BASIN HUBS COMPARED TO THE NON-LA PLATA BASIN HUBS}

As remarked, the exact perimeter of the La Plata Basin region is not a consensus. A. Schweitzer (2000), B. Azevedo (2009), R. Pérez Antón (2009), A. Rückert and C. Dietz (2013), for example, attribute in their studies, in some measure, different shapes to the region. Nevertheless, two aspects are often used to characterize it: the low population density in large tracts of land, in spite of the densely populated areas polarizing influence on them, and the strong presence of nature as a defining element of social interactions, especially the watercourses that cut through at the same time that they unite the territory.

As seen, these physical features of the territory are, according to the wording on IIRSA documentations, physical restrictions, which are attributed as characteristics of the emerging Hubs. However, it is easy to infer that physical restrictions do not equally affect the emergent Hubs that overlap in the geometric center of the subcontinent and those in the Amazon region, for example.

Furthermore, the La Plata Basin emerging Hubs also overlap the MERCOSURChile Hub, one of the two Hubs IIRSA it self highlights for their integrating potential 
and pre-existing infrastructure characteristics. In fact, in terms of infrastructure, even before IIRSA, the La Plata Basin region had already been characterized by its important stock of infrastructure, which makes it the most developed and varied in Latin America (Sánchez-Gijón, 1990, p. 111).

IIRSA literature mentions physical restrictions as key features in 8 out of the 10 Hubs of the initiative. And it's true that when large territorial portions of South America are observed, as extensive as the Hubs of IIRSA or as a mesoregion such as the La Plata Basin, hardly it will not be possible to identify some kind of physical constraint to the integration of its infrastructure. It is important, nonetheless, to differentiate this region from the others.

The table below shows the proportion of construction works that aim towards new infrastructure and those projects aiming at the improvement of existing infrastructure for each of the IIRSA Hubs. The use of this variable is justified as the conditions of the pre-existing infrastructure are among the most relevant aspects to tell emerging Hubs apart, as well as the Andean and MERCOSUR-Chile Hubs.

Those projects with any of the following specifications as for the type of work in the IIRSA database of projects (UNASUR, n.d.) were considered as new infrastructure: building of new power interconnections, building of new river ports, building of railways, transfer stations, carboelectric plants, infrastructure for installing border control centers, multimodal transportation, new airports, new sea ports, optic fiber, other energy infrastructures, paving (new work), railway by-pass, road by-pass and access to cities, thermoelectric plants. The following were analyzed on a case-bycase basis and classified as new infrastructure whenever appropriate: bridges (new ones and refitting), generation by means of nuclear power, hydroelectric plants (new ones and refitting), improvement of river navigability and tunnels (new ones and refitting).

Table 1 shows that within the same group of emerging Hubs there are the Guianese Shield and Peru-Brazil-Bolivia Hubs, which present approximately 80\% of projects that foresee the building of new infrastructure, as well as the ParaguayParaná Waterway Hub, with at least 55\% of the works aiming at refitting existing structures. In fact, the four Hubs on the La Plata Basin region are among the five with the smaller proportion of new works. This is reinforced if we observe only the set of projects that we consider to have a more direct incidence in the region specifically studied: only $45 \%$ of them are new works. Most of the projects for the 
region are aimed at improving the efficiency of an already established dynamics, one that overloads existing infrastructures.

\section{Table I}

Proportion of new works and works of improvement in each IIRSA Hub.

\begin{tabular}{lccccc}
\hline IIRSA Hubs & $\begin{array}{c}\text { Total of } \\
\text { projects }\end{array}$ & $\begin{array}{c}\text { New } \\
\text { works }\end{array}$ & $\begin{array}{c}\% \\
\text { new works }\end{array}$ & $\begin{array}{c}\text { Improvement } \\
\text { improvement }\end{array}$ \\
\hline MERCOSUR-Chile & 115 & 40 & $35 \%$ & 75 & $65 \%$ \\
Paraguay-Paraná Waterway & 84 & 37 & $44 \%$ & 47 & $56 \%$ \\
Capricorn & 77 & 40 & $52 \%$ & 37 & $48 \%$ \\
Amazon & 70 & 37 & $53 \%$ & 33 & $47 \%$ \\
Central Interoceanic & 63 & 34 & $54 \%$ & 29 & $46 \%$ \\
Southern & 45 & 25 & $56 \%$ & 20 & $44 \%$ \\
Andean & 65 & 39 & $60 \%$ & 26 & $40 \%$ \\
Peru-Brazil-Bolivia & 24 & 19 & $80 \%$ & 5 & $20 \%$ \\
Guianese Shield & 20 & 16 & $80 \%$ & 4 & $20 \%$ \\
\hline Total IIRSA & 562 & 287 & $51 \%$ & 275 & $49 \%$ \\
\hline
\end{tabular}

Table 2

Proportion of new works and works of improvement within the La Plata Basin region.

\begin{tabular}{lccccc}
\hline IIRSA Hubs & $\begin{array}{c}\text { Total of } \\
\text { projects }\end{array}$ & $\begin{array}{c}\text { New } \\
\text { works }\end{array}$ & $\begin{array}{c}\text { \% } \\
\text { new works }\end{array}$ & Improvement & $\begin{array}{c}\% \\
\text { improvement }\end{array}$ \\
\hline MERCOSUR-Chile & 82 & 30 & $37 \%$ & 52 & $63 \%$ \\
Paraguay-Paraná Waterway & 84 & 37 & $44 \%$ & 47 & $56 \%$ \\
Capricorn & 54 & 26 & $48 \%$ & 28 & $52 \%$ \\
Central Interoceanic & 29 & 19 & $66 \%$ & 10 & $34 \%$ \\
La Plata Basin region & 249 & 112 & $45 \%$ & 137 & $55 \%$ \\
\hline
\end{tabular}

It also should be noted that the same rivers that can be interpreted as physical restrictions, constitute, in practice, resources that justify part of the human settlements in the La Plata Basin, as well as alternatives for cargo and people transportation through the region. The rivers, seen as waterways, are alternatives of occupation and appropriation of space. On the contrary, for the two Hubs approaching $80 \%$ of new works, the physical features of territories corresponding to their areas of influence have always presented challenges for circulation and 
access infrastructure, which explain their low rates of compared human occupation, as seen on Table 3 .

Table 3

Population density in each IIRSA Hub area of influence.

\begin{tabular}{lccc}
\hline IIRSA Hubs & Population & Area $\left.\mathbf{( K m}^{\mathbf{2}}\right)$ & People per Km $\mathbf{~}^{\mathbf{2}}$ \\
\hline MERCOSUR-Chile & $141,453,273$ & $3,216,623$ & 44.0 \\
Andean & $111,195,797$ & $2,845,658$ & 39.1 \\
Central Interoceanic & $100,150,302$ & $2,642,262$ & 37.9 \\
Paraguay-Paraná Waterway & $119,035,634$ & $4,036,541$ & 29.5 \\
Capricorn & $53,509,280$ & $2,722,534$ & 19.7 \\
Amazon & $132,687,257$ & $8,059,085$ & 16.5 \\
Peru-Brazil-Bolivia & $12,730,732$ & $1,159,504$ & 11 \\
Guianese Shield & $17,100,505$ & $1,603,643$ & 10.7 \\
Southern & $6,473,238$ & 686,527 & 9.4 \\
\hline
\end{tabular}

The data above indicate average population density as another useful characteristic to distinguish the emerging Hubs overlapping the La Plata Basin from other Hubs. The comparison in this case was made from data of the IIRSA Project Portfolio 2016 (UNASUR, 2016b).

Since spatial distribution of population is not homogeneous, the average population density of each Hub is useful to the extent that it reflects in what proportion the territorial units of greatest population density are included by the area of influence of those Hubs. In fact, the territorial occupation of South America has historically privileged the occupation of the coast, where a large part of the population is still concentrated, whereas the eight emerging Hubs according to IIRSA classification cover mostly the interior lands of the subcontinent. The La Plata Basin region, however, includes territorial nodes of great demographic concentration, as well as the La Plata Basin Hubs.

The emerging La Plata Basin Hubs, therefore, are distinguished from the other emerging Hubs because they present larger population settlements, although there are also territorial tracts of very low population density, and because of its overloaded infrastructure, which justifies the number of improvement projects proportionally to the number of new works. 
The difference, however, between the two sets of emerging Hubs should not be interpreted as merely evidence of the pre-existence of infrastructure and the expectations to its intensive use, which are used in order to justify the demands for their improvement. The difference between these two groups mainly reflects the fact that the so-called physical restrictions identified in the La Plata Basin region have posed less constraints to the development of the kind of infrastructure preferred by national and regional integration strategies up to the present. For this affirmation to become clearer, the next section provides a review on the historical background of regional and physical integration agreements concerning the La Plata Basin borders.

\section{THE LA PLATA BASIN SYSTEM AND THE (PHYSICAL) INTEGRATION OF THE LA PLATA BASIN REGION}

In 1969, also in the city of Brasilia, the La Plata Basin Treaty was signed by representatives of Argentina, Bolivia, Brazil, Paraguay and Uruguay. More than 30 years before the launch of the plan for South American physical integration, this agreement already highlighted the importance of integrating infrastructure in transport, communications and energy sectors to the regional integration process, but at mesoregional level (Tratado da Bacia do Prata, 1969).

However, as R. Pérez Antón states, the La Plata Basin region did not arise, in any relevant sense, with the Treaty of Brasília of 1969 (Pérez Antón, 2009, p. 79). The author emphasizes with this assertion that the notion of La Plata Basin region surpasses not only the geographical concept of hydrographic basin, but also goes beyond the aforementioned agreement among the five national States. It further stresses that the La Plata Basin region, although the category of region was not deliberately attributed to it, precedes the existence of these same States.

From colonial times, the region in discussion has played a significant role in the regional dynamics of what we now understand as South America. Portuguese and Spanish shared interests and competed for the potential of the main rivers and their tributaries as waterways. In addition to the routes for the traffic of goods, whether stated as legal or illegal, the first European explorers who circulated there were also interested in increasing their capacity of control over the interior lands of the new continent, made possible through navigation along these corridors. 
About this period, the analysis of R. Pérez Antón (2009) clarifies one characteristic common to all explorers: their lacking vision of the entire area. From very early it has been established a perception of the La Plata Basin region as a place for traffic. Control over the water path was a greater concern than the development of the lands surrounding it. Added to this is the fact that the end of the colonial period was marked by the creation of national States in which the administration is politically and geographically centralized, situation that leads to the concentration of the decision-making process on spatial planning and, often, a mismatch between the needs of the center and those of territorial units distant from these centers - in this case, a potential mismatch between local interests in the mesoregion, specially along international borders, and national interests.

Many researchers, such as A. Sánchez-Gijón (1990), E. Zugaib (2006) and A.-L. Amilhat Szary (2010), agree that the interaction among centralized States, such as regional agreements with integration goals, have been insofar insufficient for enabling an effectively regional administration of this cross-border territory. Although correct, the fact should not overshadow the perception and recognition, by these same States, of the existence of this territory as a distinct region. The succession of treaties and organizations that refer to the La Plata Basin region as such, although the limits of this area are unclear, is proof of this recognition: see the La Plata Basin System, institutionalized with the 1969 treaty, in addition to the Paraguay-Paraná Waterway intergovernmental committee and the multilateral development fund FONPLATA.

Even though the committee for the Waterway management, in operation since 1989, is part of the La Plata Basin System, the project for the waterway actually precedes the La Plata Basin Treaty of 1969. Proof of this is that the Paraguay-Paraná Waterway is cited as one of the priority instruments for the development of the La Plata Basin region. In addition, as suggested, the use of Paraguay, Paraná and Uruguay Rivers was already a cause of dispute during the colonial period, and some disagreements remained for decades after the signature of the Treaty in 1969. The conflict between the so-called national interests had great repercussions for this set of river routes, especially, as A. Sánchez-Gijón (1990) and E. Zugaib (2006) managed to elucidate, between the interests of Brazil and Argentina.

E. Zugaib (2006, p. 91) explains that this dispute of interests was reflected in the transverse versus longitudinal Hubs contradictions, giving rise to the policy 
of export corridors in the east-west direction, advised by Brazilian geopoliticians since at least the 1930s, although accentuated from the 1970s to the 1980s. The Brazilian strategy to overcome the lack of infrastructure within its territory in the $20^{\text {th }}$ century was conceived as to curb Argentinian influence over these areas, as this country would benefit from north-south connections, such as the Waterway.

The rapprochement of Argentina, Bolivia, Brazil, Paraguay and Uruguay for the coordination of regional initiatives regarding the La Plata Basin region has succeeded to raise the issue of improving the conditions of navigability and logistical infrastructure along the waterways. Only two decades later, though, the Intergovernmental Committee of the Paraguay-Paraná Waterway was created under the scope of the La Plata Basin System.

The period coincides with the growing Brazilian interest in promoting the products from the same areas that it previously tried to prevent from Argentinian influence. The expansion of the Brazilian agricultural frontier had boosted the population as well as the crops cultivation such as that of soy in this region. As a result, the viability for export of the La Plata Basin production was understood as directly dependent on the investment in reduction of transportation and storage costs. South American physical integration was thought so far, from the point of view of Brazilian foreign policy, as the connection between the two oceans, a logic that still plays a significant role to this day. However, from that time on, an opportunity was opened for the complementation of the bi-oceanic discourse with the discourse of internal connection to and through the La Plata Basin.

Nonetheless, there are different interpretations whether the Paraguay-Paraná Waterway is an advance or an estrangement from integration goals stated by the La Plata Basin Treaty of 1969. About the latter, R. Pérez Antón (2009) defines it as a sectoral policy of integrating inspiration on which is based an attempt at supranational management of this territory, although the treaty alone does not effectively establish supranational powers. However, he also affirms that other initiatives, anchored the regional appropriation of the rivers, such as the improvement of Paraguay-Paraná Waterway navigability, managed to dissipate these efforts.

P. Ligrone and L. Ménanteau (2009, p. 185), in turn, highlight the fact that the Paraguay-Paraná Waterway is a project aimed at the renewal of river transport mode at macroregional level. The authors emphasize that the project enhances the accessibility and add to the transportation capacity through the areas within the 
subcontinent, unlike what occurred during most of the $20^{\text {th }}$ century, marked by the growth and concentration of metropolitan areas on the Atlantic coast.

In effect, once the territorial development model focused on the coast, it encouraged priority development of coastal roads, subsidiary to maritime connections with other continents, prone to maintain some of the inherited relations from the colonial period. The Paraguay-Paraná Waterway, also known as Puerto Cáceres-Nueva Palmira project and listed by IIRSA, points out an alternative to diversify transport across the continent, while also undoubtedly increasing the access to remote areas in the subcontinent.

It is a fact that the Treaty signed in April 1969 states in its first article the intention of promoting balanced development and physical integration on the cross-border mesoregion, in order to ensure the common and sustainable use of natural resources. Although not specified, it is possible to interpret from the reading of the rest of the document that the notion of balanced development includes not only improvements in transport, energy and communications infrastructures, but also cooperation on economic, health, education and environmental issues. Therefore, aiming at broader objectives than the improvements concerning the waterway infrastructure.

In practice, despite the range of its goals, the initiatives directly associated with the La Plata Basin System, emphasize the theme of water resources use. The rapprochement between the States in this region, institutionalized by the Brasília Treaty, is, however, frequently cited, such as in the works of E. Zugaib (2006), B. Azevedo (2009) and P. Ligrone and L. Ménanteau (2009), as having a relevant role as a precursor to the integration process that would give rise to the Southern Common Market.

Other than that, as A.-L. Amilhat-Szary (2010) underlines, the case of the Fondo Financiero para el Desarrollo de la Cuenca del Plata (FONPLATA) is to be considered as well: a regional organization designed to fund regional integration also derived from the Treaty of $1969^{10}$. FONPLATA was constituted in 1974 and underwent an institutional reform in 2010 that equipped it to function as a

10 For the French researcher, the Brasilia agreement of the late 1960s is among the few examples of Latin American mesoregional strategies that aim for a territorial approximation, a dimension of integration processes often ignored by economic institutions. 
regional development bank. According to its annual reports from 2005 to $2016^{11}$, FONPLATA's operations revolve mostly on financing infrastructure projects, which include some listed by IIRSA portfolio, as well as other smaller budget projects in areas of international border or within the national territories of its five members.

In summary, although the La Plata Basin Treaty provided broader expectations in its text, improvements in terms of physical integration and the use of water resources were the priority issues for the creation of the regional intergovernmental system, implying that these would be the catalysts of integration and development. In this sense, the Paraguay-Paraná Waterway is in the genesis of the constitutive text of 1969 , as well as the emergence, two decades later, of an agreement specifically addressing this issue. The FONPLATA, in turn, is another example of the La Plata Basin System ramifications, as it is a regional instrument for financing projects that can contribute to the realization of the System's goals.

However, at the present, only the emphasis on the need for connection infrastructure remains. Moreover, the waterways certainly do not play the protagonist role on the mesoregion's development discourse. A role that, in terms of execution of projects, had ceased to exist much earlier.

At the end of the 1980s, A. Sánchez-Gijón had assessed the infrastructure situation in the transport, energy and telecommunications sectors in the La Plata Basin region. Since then, the author had identified the need for resumption of water and railways as an alternative to which was already considered an overloaded road network. A. Sánchez-Gijón (1990) concludes by unfolding the historical progress of infrastructural development in the region. According to his research, the level of integration of the transport systems is inversely proportional to the age of the subsystems involved (Sánchez-Gijón, 1990, p. 127), that is to say, the roads subsystem, more recent than the waterways, is far more integrated and developed than the river transport (and communication) subsystem, despite its importance to the colonial strategies of territorial appropriation. Along the same lines, he places the railroads as losing its importance notwithstanding the role they played to the consolidation of the Nation States in the $19^{\text {th }}$ century.

At this point, despite the contemporary intensification of the potential for infrastructural development, especially when compared to the technical limitations 
of the colonial period or even the political-economic limitations up until the mid-twentieth century, the researcher's conclusion remains valid nowadays. Although river and railway modalities are covered by the IIRSA plan, there is a clear preponderance of the road sector among the works in execution or already concluded after the launch of the initiative: currently there are 181 road, 30 river and 24 railway projects categorized in such phases. Similarly, among the projects of the four Hubs of IIRSA analyzed above, only $8 \%$ of the works in the transport sector belong to the railway sub-sector, and $14 \%$ to the fluvial one (UNASUR, n.d.).

It is possible, however, to identify that progress has been made since the $2000 \mathrm{~s}$ in energy interconnection matters: half of the 12 completed IIRSA energy projects for the La Plata Basin region refer to interconnection lines. The other six completed projects are for the power generation sub-sector and illustrate the diversity of sources used for power generation in the region, as they include three thermoelectric power plants, one nuclear power plant and two improvement works in the Yacyretá Binational Hydroelectric Plant. The Garabí and Corpus Christi hydroelectric plants, mentioned in the Sánchez-Gijón study and subject to binational agreements at least since 1980, are listed by IIRSA portfolio, but both are listed by IIRSA's database of projects as in the pre-execution phase (UNASUR, n.d.).

It is worth remembering at this point that IIRSA compiles existing projects proposed by one or more South American States and these projects are therefore elevated to the category of projects of regional interest. IIRSA, not unlike the La Plata Basin System at regionalism level, aims to coordinate at the same time as it is the result of intergovernmental negotiations. Both regional integration initiatives reflect the interests of its States Parties, and their capacity for implementation is limited to the actions taken by those States.

On this regard, attributing the reason to the completion of works after the year 2000 to the existence of IIRSA may lead to premature conclusions. In order to do so, it would be necessary to analyze each individual project to know the role of the initiative in carrying them out, since these projects had been considered priorities for years and many other conjuncture factors may have influenced their achievement. The IIRSA, however, represents a great advance in the ability to follow up all projects listed in its portfolio through a common regional tool and, precisely, to compare how the South American initiative can have different repercussions in the various sub-regions within the subcontinent. 


\section{FINAL CONSIDERATIONS AND CONCLUSIONS}

The IIRSA planning strategy can help to identify the sub-national repercussions of the integration process in South America. Even if IIRSA tends to prioritize territorial interventions associated with commodities trade, the integration Hubs and their subdivision into groups of projects, with smaller areas of influence, allow us to verify what interests are being assigned to these territories, although the motivations and resulting decision-making process of IIRSA are still centralized in the larger national centers. That is why we should emphasize the word assigned.

In this study, the La Plata Basin Hubs of IIRSA were analyzed, with emphasis on the groups of projects that are located in the region. This way it was possible to comprehend the role attributed to that region by the current physical integration plan, agreed among the independent States of South America. This assessment is of particular interest because the La Plata Basin region comprises large cross-border spaces, less populated and less equipped with infrastructure in transport, energy and communication sectors, while also comprising economic and political national centers. As a result, we could identify that the mesoregion reproduces the centerperiphery logic, also applicable to explain the extractive-export development model often attributed to the whole IIRSA as well as to other regional initiatives in South America.

The characterization documents of each IIRSA Hub, in regard to the population of their respective areas of influence, corroborate the idea of a region that is, in fact, quite populated when compared to other large spaces within South America. It is known, however, that this population rates reflect the great concentration of people in a small number of urban settlements in contrast to areas of low population density. In addition, it was found that this region, still in comparative terms within South America, is more developed in terms of infrastructure, playing a leading role for South American integration. Being at once under the influence of four out of the ten integration and development Hubs of IIRSA, the situation indicates the existing connections are far from enough to sustain the regional development and flows.

The study of the region through IIRSA documents is useful to understand to what extent the development interests for this region are contemplated by the initiative, although from the point of view of the national and centralized States of 
South America. But what would be the interests emanating from the mesoregion? The material hereby analyzed is not enough to accurately define these. It is possible, though, to reaffirm the recognition by the States about the need for cross-border regional treatment of development issues located at this particular region. In practice, IIRSA's multi-scale strategy makes possible to realize which are the central interests in this central-peripheral mesoregion. However, only from more detailed case studies would it be possible to identify the region interests as defined by regional territorial actors.

The physical integration strategy subject to this study is evidence, above all, to the selectivity of the national centers toward the demands of peripheral areas. Sub-national interests mentioned in the IIRSA projects are only implemented and enforceable insofar as they add up to the integration model privileged by national strategies, even when the latter is eventually inconsistent with integrationist discourses risen from those same centers. See, for example, the preponderance of roads to the detriment of railways and waterways for the transportation of goods, although these two last modalities had repeatedly been referred to as more efficient and cost-saving alternatives, even before the launch of IIRSA.

Nevertheless, the comparative approach to La Plata Basin and non-La Plata Basin Hubs clarifies what the overlap of three of the emerging IIRSA Hubs and the MERCOSUR-Chile Hub means to the mesoregion in case. The ParaguayParaná Waterway and Capricorn Hubs reveal complementary strategies, focused on the transposition of physical restrictions and the use of water resources, especially with the purpose of implementing multimodal transportation alternatives for the commerce of agricultural goods from the central area of South America.

The socioeconomic characterization of the Central Interoceanic Hub is equally relevant, for it demonstrates the income disparities within the La Plata Basin, with clear concentration in the Southeast region of Brazil. Also, the fact that the proportion of the Central Interoceanic new works projects located in the La Plata Basin region is greater (more than 65\%) than the ratio of the same kind of projects for the entire Hub (54\%) suggests that the Basin region area under its influence is precisely where the Hub lacks the most in connections. This situation reflects a weaker physical connection between Brazil and Bolivia than the one between Brazil and other countries in the Basin.

Regarding the MERCOSUR-Chile Hub, its main goal of connecting MERCOSUR's founding members to Chilean ports, in addition to a number of 
improvement projects in the conditions of Atlantic ports, suggest one more time a priority approach to the exportation of agricultural production from the La Plata Basin. The same roads, though aimed to the transportation of cargo, certainly have a relevant impact on the connectivity among the mesoregion cities and, therefore, their populations. The analysis of preexisting conditions of this Hub, the only one not classified as emerging by IIRSA, shows there is already an advanced regionalization of flows within the La Plata Basin region. Besides, given the privilege to the road network and the extremely low use of railways for the transportation of passengers, it, optimistically, suggests that this Hub is to positively affect the conditions for people circulation as well as for cargo.

Together, the goals of these four Hubs reinforce the central role that exportoriented crops productions, especially of soy, play in the development strategy designed by the national centers for the La Plata Basin region. All Hubs reference soy among the products to benefit from the physical connections, no other product being as much mentioned. There are, however, projects aiming for different objectives, such as power interconnection or touristic appropriation of part of the pre-existing railway network. Analyzed individually, however, the courses of these projects, even when carried out, reveal cases of existing structures not actually in operation.

Moreover, a fundamental result of this analysis is that the La Plata Basin region is also a legitimate IIRSA's laboratory. The status attributed to the MERCOSURChile is, in fact, partially due to the fact that this Hub has its area of influence mainly over the mesoregion. In addition, this Hub certainly is to IIRSA a space for carrying out pioneering studies and initiatives that can be used as an experiment for South American physical integration. Nevertheless, for the purpose of analyzing IIRSA's territorial repercussions, the La Plata Basin region and, consequently, the analysis of all four Hubs is substantially more accurate.

The variety of projects, the complementarity between Hubs, the preponderance of road transport modality in all Hubs, whether emerging or not, the contrast between more or less populous areas of influence and even the repeated mention of a reduced number of economic activities, in this case one single agricultural sector, all these aspects characterize the La Plata Basin region under IIRSA's influence.

Those interactions or assertions can only be accurately evaluated, though, through the analysis of a region or sub-region, other than one Hub. Even the strategies adopted by the Brazilian foreign policy toward the mesoregion are a starting point 
for understanding the role played by this country in the physical integration of South America. Consequently, it is possible to infer from these results that the $\mathrm{La}$ Plata Basin region regroups all of IIRSA integration and development expectations and strategy in a regionalist scale.

With that being said, it is of utmost importance to recognize that, at South American level, the La Plata Basin mesoregion actually comprises actually the components to be the center of the physical integration process and current regional plan. The preponderance of projects aiming for the improvement of already existing connections, the historical background here only briefly assessed and the relative proximity to the economic and political centers that polarize the mesoregion are some of the aspects that corroborate this hypothesis, which should be further explored with the replication of this study to other South American sub-regions.

\section{REFERENCES}

Amilhat Szary, A.-L. (2010). Frontières et intégration régionale em Amérique latine : sur la piste du chaînon manquant. In C. Flaesch-Mougin \& J. Lebullenger (Eds.). Regards croisés sur les intégrations régionales (pp. 307-341). Brussels: Bruylant.

Araújo, T. B. (2000). Dinâmica regional brasileira nos anos noventa: Rumo à desintegraçáo competitiva? In: CASTRO, I. E. ; MIRANDA, M. \& EGLER, C. (Eds.). Redescobrindo o Brasil: 500 anos depois (pp. 73-89). Rio de Janeiro: Bertrand Brasil.

Azevedo, B. (2009). Le Bassin du Río de la Plata dans la période coloniale : une histoire commune pleine d'actualité. In M. Guibert, S. C. Carrizo, P. Ligrone, B. Mallard, L. Ménanteau \& G. Uribe (Eds.), Le bassin du Río de la Plata: Développement local et intégration régionale (pp. 105-127). Toulouse: Presses Universitaires du Mirail.

Carrion, M. C. and Paim, E. (2006). IIRSA: Desvendando os interesses.Retrieved from: $<$ http://www.riosvivos.org.br/arquivos/iirsa_eli.pdfs

Carvallho, G. (2003). A estratégia da integração da infra-estrutura da América do Sul e o governo brasileiro. Retrieved from http://www.biodiversidadla.org

Ceceña, A. E., Aguilar, P. and Motto, C. (2007).Territorialidad de la dominación: La Integración de Infraestructura Regional Sudamericana (IIRSA). Buenos Aires: Observatorio Latinoamericano de Geopolítica.

Comunicado de Brasília. (2000). Retrieved from: <http://www.iirsa.org/admin_iirsa_web/ Uploads/Documents/comunicado_brasilia_esp.pdf > 
Dijk, P. (2008). Troublesome construction: the rationale and risks of IIRSA. European Review of Latin American and Caribbean Studies, 85, 101-120.

Fondo Financiero para el Desarrollo de la Cuenca del Plata. (n.d.). Reportes Anuales. Available from http://www.FONPLATA.org/comunicaciones/reportes-anuales.html

Initiative for the Integration of Regional Infrastructure in South America. (2009). Indicative territorial planning: Project Portfolio IIRSA 2009. Retrieved from: <http://www20. iadb.org/intal/catalogo/PE/2009/04494en.pdf>.

Initiative for the Integration of Regional Infrastructure in South America. (2011). IIRSA 10 years later: Achievements and challenges. Buenos Aires: BID-INTAL. Retrieved from <http:// www.iirsa.org/admin_iirsa_web/Uploads/Documents/1b_iirsa_10_anios_sus_logros_y_ desafios_eng.pdf>

Inter-American Development Bank. (2000). Un nuevo impulso a la integración de la infraestructura regional en América del Sur. Retrieved from: <https://publications.iadb.org/ handle/11319/3765? locale-attribute=en>.

Koutoudjian, A. (2007). Visión de negocios del Eje de la Hidrovia Paraguay-Paraná. Retrieved from: <http://www20.iadb.org/intal/catalogo/pe/2009/02858.pdf>.

Ligrone, P. and Ménanteau, L. (2009). Hídrovia, patrimoine fluvial et industrie du bois: le bas Uruguay(argentine, Uruguay) entre intégration transfrontalière et rupture. In M. Guibert, S. C. Carrizo, P. Ligrone, B. Mallard, L. Ménanteau \& G. Uribe (Eds.), Le bassin du Río de la Plata: Développement local et intégration régionale (pp. 77-103). Toulouse: Presses Universitaires du Mirail.

Malagolini, A. (2016, October 11). Do Trem do Pantanal, sobrou estação fantasma e o último funcionário. Campo Grande New. Retrieved from: <https://www.campograndenews. com.br/cidades/do-trem-do-pantanal-sobrou-estacao-fantasma-e-o-ultimo-funcionario $>$.

Ospina, G. (2007). Visión de negocios del Eje MERCOSUR-Chile. Retrieved from: <http:// www.iirsa.org/admin_iirsa_web/Uploads/Documents/mcd_vn_2007.pdf>.

Pérez Antón, R. (2009). Política, espacio e integración em la Cuenca del Río de la Plata. In M. Guibert, S. C. Carrizo, P. Ligrone, B. Mallard, L. Ménanteau \& G. Uribe (Eds.), Le bassin du Río de la Plata: Développement local et intégration régionale (pp. 77-103). Toulouse: Presses Universitaires du Mirail.

Rückert, A. and Carneirro Fillho, C.P. (2015). A gestão contemporânea das fronteiras do Brasil: defesa e separação x cooperação e integração. Anais do XVI Encontro Nacional da ANPUR. Belo Horizonte, MG: ANPUR.

Rüickert, A. and Dietz, C. (2013). Integração regional, a região transfronteiriça da bacia do Rio da Prata e os projetos de infraestruturas de conexão. Confins, 7. Retrieved from: <http:// confins.revues.org/8216>.

Sánchez-Gijón, A. (1990). La integración em la Cuenca del Plata. Madrid: Ediciones de Cultura hispánica. 
Scavini, A.S. (2011). L'Amérique du Sud, le nouveau paradignme brésilien de l'intégration régionale (Master's thesis). Université Paris 1 Panthéon Sorbonne, Paris.

Scheibe, E. (2012). Iniciativa para integração da infraestrura regional sul-americana (IIRSA): Consideraçôes preliminares sobre objetivos, atores e escalas de ação. Para Onde!?, 6, 01-06. Retrieved from: <http://seer.ufrgs.br/index.php/paraonde/article/view/35704>.

Scheibe, E. and Rüickert, A. (2014).A iniciativa para integração da infraestrutura regional sul-americana (IIRSA) como instrumento multiescalar de integraçáo. In A. Dorfman; C. I. Pacheco Sánchez; S. Y. Fernández Moreno. (Eds.). Planos geoestratégicos, migraçôes e deslocamentos forçados no continente americano (pp. 55-74). Porto Alegre: Letra1; IGEO/UFRGS.

Schweitzer, A. (2000). Aménagemenent du territoire et intégration régionale dans le MERCOSUR. Frontières, réseaux et dynamiques transfrontalières (Doctoral dissertation). Université de Paris III Sorbonne Nouvelle, Paris.

Silva, A. R. (2011). Perspectivas das politicas territoriais na Faixa de Fronteira internacional da Amazônia Oriental brasileira: Estados do Pará e do Amapá (Master's thesis). Universidade Federal do Pará, Belém.

Silva, E. B. (1997). Infra-estrutura para desenvolvimento sustentado e integração da América Latina. Rio de Janeiro: Expressão e Cultura.

Sosa Pinilla, P. M. (2007). Visión de negocios del Eje de Capricornio. Retrieved from: <http:// www20.iadb.org/intal/catalogo/PE/2008/01724.pdf>.

Sosa Pinillla, P. M. (2008). Visión de negocios del Eje Interoceánico Central. Retrieved from: <http://www20.iadb.org/intal/catalogo/PE/2008/01819.pdf>.

Svampa, M. (2011). Néo-"développementisme" extractiste, gouvernements et mouvements sociaux em Amerique latine. Problèmes d'Amérique latine, 81(3), 101-127.

Tratado da Bacia do Prata. (Apr. 23, 1969). Retrieved from: <https://www.dpc.mar.mil. $\mathrm{br} /$ sites/default/files/ssta/legislacao/hidrovia/trat_bcprata.pdf $>$.

Union of South American Nations. (n.d.). Information system project portfolio of COSIPLAN [South American Infrastructure and Planning Council]. Available from: <http://www.iirsa. org/proyectos/Principal.aspx>.

Union of South American Nations. (2016a).Caracterización socioeconómica y ambiental: Eje Interoceanico Central. Retrieved from: <http://www.iirsa.org/Document/Detail? Id=4298>.

Union of South American Nations.(2016b). Project portfolio 2016. South American Infrastructure and Planning Council. Retrieved from: <http://www.iirsa.org/Document/ Detail? Id $=4424>$.

Zugailb, E. (2006). A hidrovia Paraguai-Paraná e seu significado para a diplomacia sul-americana do Brasil.Brasília: Fundação Alexandre de Gusmão. 



\section{ENERGY TRANSITIONS AND REGIONAL INTEGRATION IN SOUTH AMERICA}

\section{Silvina Carrizo \& Sébastien Velut}

\section{ABSTRACT}

South American countries have very different energy mixes but, with the exception of Brazil, these are not very diversified. The dependence on fossil fuels remains strong even in this continent rich in agricultural and other energy resources. In this sense, diversification possibilities are wide. States are concerned about new energy sources promotion, but there is no shared vision of a common energy future. On the contrary, integration is rather seen as a means to ensure the existing functioning by limited exchanges, rather than as a genuine transition instrument.

KEYWORDS Energy, integration, South America, transition, regulation. 
In South America, abundant energy resources - oil, gas, coal, uranium, hydro, geothermal, wind, sun and biomass-are distributed all over the continent. Although regional energy production represents about $5 \%$ of the world total ${ }^{1}$ (Enerdata 2017), it stands out as the world region with the highest share of renewable energies in electric production, thanks to hydropower. It is also a leader in biofuels production, with Brazil as the main world producer of sugarcane bioethanol and Argentina as a big exporter of biodiesel from soy oil. These two products have occupied energy niches, reached by technological leaps (Reddy and Goldemberg 1990). Compressed natural gas (CNG) in Argentina and oil produced in Brazilian deep waters also illustrate regional capacity to advance with new production and service spaces, created and adapted by local economies (Guyer 2004). Each country found those niches and innovated to respond to the challenges of reducing oil imports dependences (Droulers and Carrizo 2011). Both countries have built powerful national-industrial models in those four sectors, which became references at international level. Moreover hydroelectricity, biofuels and CNG favour a relatively low $\mathrm{CO}_{2}$ emission rate ${ }^{2}$. Greenhouse gases balances are acceptable in the region in spite of high level of energy consumption compared to population and GDP (Acquatella, 2008).

South American countries are facing different types of problems regarding energy supply. In some of them, problems arise from the low production capacity, dependence on imports of oil and gas and uncertainties about supplies. For instance Argentina and Brazil, two countries with large non-conventional resources, depend on gas imports. Ecuador or Peru have low levels of consumptions and are exporting hydrocarbons, but they must import fuels because they do not have an adequate refining capacity. In countries with substantial endowments of energy resources, rejection by local communities of large scale new energy projects, such as oil and gas production - particularly of non-conventional resources - or the building of power facilities also triggers social protest. Another set of problems are mainly related to

\footnotetext{
* The article was written in 2017 and it does not account for the events that affect South American integration processes in 2018.

1 In 2016, world total primary production was 13,909 Mtoe. Latinoamerica produced 7\% of world total (1,018 Mtoe) and in South America, Argentina (78 Mtoe), Brazil (287 Mtoe), Chile (12 Mtoe), Colombia (125 Mtoe) and Venezuela (174 Mtoe) together contributed with 4,8\% of it.

2 Average emissions are of 5,5 tons of $\mathrm{CO} 2$ equivalent per capita excluding emissions from land use change and forestry (CEPAL, 2010).
} 
the technological options, transport, increase of industrial capacity, quality and extension of energy services, consumption inefficiency and energy poverty.

Countries are facing a set of issues related to energy that might encourage them to reinforce energy transition and increase the level of integration within the region. This paper explores the connection between these two dimensions. On the one hand governments are eager to develop energy offer relying on conventional and nonconventional sources, shifting the countries' energy mix to make them more secure and sustainable. On the other hand they have been engaged in a complex process of regional integration in which energy integration is seen as one fundamental pillar.

Governments conceive new norms and legal frameworks, offer incentives and assume international commitments. They tend to facilitate investments in their energy systems and favour an energy transition towards new energy sources and patterns of consumption. Private or public-private initiatives for the inclusion of new sources and technologies emerge. They are part of national endeavours to make energy systems more distributed, more diversified and socially equitable.

This paper addresses the issue of energy transitions and regional integration in South America, as changes carried out by States and influential economic groups, to develop energy networks. While private companies often respond to global strategies, governments try to preserve national sovereignty in dealing with firms and with neighbouring countries. But they must also overcome existing deficits and provide services to households and industries, while private companies must deal with political uncertainty and legal inconsistency. Cooperation between states and private companies opens spaces for large-scale projects, but these face many obstacles due to the lack of a regional framework for energy integration. Differences between countries in resources availability complicate the whole integration process, because national interests might diverge. At the same time, they open more opportunities for complementarities. Nevertheless national programs to incorporate new energy sources do not consider these regional options.

To discuss these topics, this paper is structured in three parts. The first one presents the main characteristics of national energy mixes which, with the exception of Brazil, show a low level of diversification. The second part refers to changes that facilitate the incorporation of renewable energies and the adoption of more rational and efficient use of resources. The third part analyses regional integration processes from the perspective of a transition towards new models. 


\section{ENERGY OUTLOOK: FACING NATIONAL ENERGY CHALLENGES}

All South American countries are dependent on hydrocarbons and have abundant hydro power. Three groups can be identified: the first includes countries exporting oil and gas; the second, countries able to cover national needs with their own production; and the last one, countries that rely on oil and gas imports. According to this simple criteria, countries show a higher diversification of the energy mix and exhibit different attitudes towards foreign companies. Countries are presented according to the level of energy consumption.

- Brazil is the main energy consumer in the region and the eighth in the world (297 Mtoe, BP 2017). It has achieved self-sufficiency; energy diversification with long-term policies contributed to it. Dependence from imported oil in the 1970s led the State to support the development of renewable energies as well as oil production.

Brazil became the main producer of oil and the second regarding oil reserves (mainly located offshore and in Amazonia) in the region. PETROBRAS - a company under State's control - dominates the activity. It has received strong support from the national governments since the 1990s, gaining priority access to offshore concessions and receiving funding through the National Bank for Development (BNDES). This helped PETROBRAS to become a world-reference in deep-water technology, allowing the company to produce more oil and gas and discover the fields of the presal, a ultra deep deposit. The rise of national production of oil and gas production makes possible to loosen the dependency from Bolivian gas exports.

Since 1975 and for more than three decades, the State supported the Proalcool programme, which promoted bioethanol production. Thanks to this, Brazil became the main producer of ethanol in the world, overcome in 2009 by the United States, which produces it from corn. A better use of the waste - the bagasse - burnt to generate electricity, makes the whole process more energy-efficient and price competitive.

The national interconnected system is unique due to its dimensions: 2,500 generating stations, 115,000 MW of installed power and 100,000 km of hightension lines. It stretches from the south boundary, with Uruguay, up to the city of Belém, in the north, covering $50 \%$ of the national territory. The remaining part 
of the country, with little population, is supplied by isolated systems, with 350 generating plants that provide $3.4 \%$ of the electricity. Besides, Brazil is connected with Venezuela through a line of $230 \mathrm{kV}$ that serves Roraima state. The binational Itaipú dam (14,000 MW) - shared with Paraguay - strengthens the system in the south. Two power transmission lines were also laid from Argentina to allow imports and exports of energy. Electric connections also exist between Brazil and Uruguay, which also buys electricity transported through Argentina; an operation by means of a third party, exceptional in South America.

Brazil - as Argentina - developed nuclear energy, but at the beginning of the $21^{\text {st }}$ century, hydroelectricity was responsible for $80 \%$ of total generation. However, the low hydraulicity of 2001 resulted in a crisis that - apart from energy rationing for several months - led to diversifications with gas power stations. To expand natural gas, Brazil connected its main energy consumption centres to Bolivia and Argentina gas fields. A gas pipeline and a central station in Uruguaina - border town - were built to receive expected gas imports from Argentina. Nevertheless, these were cancelled by the government due to decrease in gas production.

- Argentina has bet on gas since the 1950s. Its natural gas consumption is diversified, intense and extended. At the beginning, gas was distributed through pipeline networks, for heating, cooking and industry. Currently it is also used as a car fuel (with one of the main CNG vehicle fleets in the world) and by generating plants. It provides more than half of the energy used in the country. Oil follows it in importance, providing a third of the needs. The rest is completed by hydroelectricity, nuclear energy and other renewable sources. The electrical system covers $99 \%$ of inhabitants, interconnecting all the regions in the country and Brazil, Chile, Uruguay and Paraguay systems. With these two countries, it shares respectively the dams of Salto Grande and Yacyretá. Isolated population, not connected to the national system, has individual solar panels or micro supply systems. The hydraulic potential is very high but the part provided by hydroelectricity $(29 \%)$ is the lowest in the region. Although Argentina has become the main world exporter of biodiesel from soy, the energy balance depends increasingly on imports.

- Venezuela is an OPEC founding member, the eighth oil exporter in the world (1.9 million barrels per day, OPEC 2015) and it possesses the largest 
reserves in the world. PDVSA - the State Company created in 1976 - in association with great foreign companies, such as PETROBRAS (Brazil), CNPC (China), ONGC (India) and PETROPARS (Iran), seeks to develop extra-heavy oil resources from the Orinoco belt. PDVSA also owns important refining capacity, in the country and outside it, particularly in the United States. Oil provides $40 \%$ of the energy that the country needs, and gas contributes with $35 \%$, but this is used mainly to extract oil, being re-injected in fields to enhance recovery ratios. Hydroelectricity covers the remaining demand, basically from a great dam in Guri river, also connected with Brazil.

- Colombia acquired the fourth place among coal exporters in 2015 (155 Mt, IEA 2017), a resource increasingly demanded. Since 2008, it has sold natural gas to Venezuela through a gas pipeline, originally built to sell Venezuelan gas to Central America. The Colombian power grid is also connected to Venezuela and Ecuador. Although flows between the countries are marginal, those connections contribute to construct a regional system considering existing links between Venezuela and Brazil as well as Ecuador and Peru. Oil exports are growing, especially since guerrillas' attacks to oil facilities decreased. Oil provides $39 \%$ of the energy to the country, and hydroelectricity 26\% (BP, 2017).

- Chile needs to satisfy increasing demands from mining and industry, two strategic sectors for its economy. Currently, it imports two thirds of its energy, mainly oil, coal and liquid natural gas (LNG). Its oil and gas fields are already mature, and their production decreases while coal fields are almost unexploited, due to the high contents of sulphur in Chilean coal. Consequently, national electricity production relies mainly on hydroelectricity. Nevertheless, recent projects have met strong opposition. People also contest coal and geothermal power for environmental issues. Imports from Bolivia are almost impossible. The interconnection of the three Chilean regional power systems is difficult to tackle due to distance, natural obstacles and the opposition of dominant actors ${ }^{3}$. All these factors

3 The central interconnected system $(9,100 \mathrm{MW}$ of capacity, mainly hydroelectric) supplies $93 \%$ of the population. It finishes near the interconnected system in Norte Grande (3,650MW of installed capacity, mainly thermal), which supplies the mining region with $5 \%$ of population, but $19 \%$ of the national demand. There are also two isolated small systems - Aysén and Magallanes with $100 \mathrm{MW}$ of capacity - in the south end, which assist $2 \%$ of the population and $1 \%$ of consumption. 
increase the uncertainty about energy scenarios in Chile.

- Ecuador constitutes the smallest producer of OPEC, but it stands on the third place in South America for proven oil reserves, after Venezuela and Brazil (OPEC 2015). It is extremely dependent on oil, which provides $72 \%$ of primary energy (BP 2017), and its export represents a higher income source. Sixty per cent of those external sales are to North America (OPEC 2015), but it aims at incorporating China among its main customers. Despite that, Ecuador has not a sufficient refining capacity and it has to import an important part of processed fuel.

- Peru has high and varied energy potential. Since 2009, it has increased electrification levels and, by $2012,91 \%$ of households $(6,155)$ had electricity (CIER 2013). Its main energy sources are oil, gas and hydroelectricity, which provide respectively $45 \%, 28 \%$ and $21 \%$ of primary energy consumption. The exploitation of the mega-field Camisea, in Amazonia, connected to Lima city, through a gas pipeline operating since 2004, has pushed up gas consumption. Peru exports liquefied natural gas since 2010, mainly to the United States and Mexico. It also exports heavy oil, because its refineries cannot process it; but it has imported light oil since 1995, especially from Ecuador.

- Bolivia, a country with conspicuous gas reserves, has exported gas to Argentina since the 1970s, and to Brazil, since 2002. However, the national supply is limited, and projects to export liquefied natural gas through the Pacific have not been settled due to geopolitical problems with Chile and Peru. Bolivian society was opposed to taking it out through Chile, and the companies were not willing to pay for the higher costs implied by taking it out through Peru. Gas has become the main fuel for electric generation. In $2013,60 \%$ of the electricity was obtained from gas (4,770 GWh), and $31 \%$ was hydroelectricity $(2,515 \mathrm{GWh})$. The national and isolated electric systems are limited. Electrification has been expanded, but $12 \%$ of the population still have no service. Bolivia has the lowest regional level of electrical consumption $-775 \mathrm{kWh} /$ capita - far below the second one, 1,300 $\mathrm{kWh}$ /capita in Colombia (CIER 2013).

- Paraguay is one of the main world exporters of hydroelectricity, since it sells $100 \%$ of the production of the huge dam of Yacyretá to Argentina, and 84\% 
of the Itaipú dam, the second largest in the world, to Brazil. The national power station Acaray completes the hydroelectric offer that provides $54 \%$ of the energy used in the country; the rest is practically provided by oil, totally imported, mainly from the Argentinean bordering province, Formosa. Paraguay produces biodiesel from soy. Despite its privileged situation in hydroelectric generation, the system presents deficits in transmission due to lack of investment in order to reach the whole country and to respond to the increase in demand.

- In Uruguay $50 \%$ of the installed power capacity is hydraulic (1,538MW), but hydroelectricity represents a bigger part in generation $(8,234 \mathrm{GWh}$ in 2013, equivalent to 76\%) (CIER 2013). Uruguay does not produce hydrocarbons, which are imported by ANCAP - State Company. Uruguay widened and renewed its generating park to work with gas, but imports from Argentina could not be sustained in time. The State company UTE [National Administration of Power Generation and Transmission Facilities], created in 1912, had the monopoly of electric generation until the opening of the binational dam Salto Grande in 1979; it still has monopoly in transmission (1,000 km of power lines, with generating plants relatively close to consumption centres) and manages an important part of distribution. Interconnections with Argentina-in San Javier and Salto Grande - and with Brazil - in Rivera - are very important for Uruguay, to reinforce system safety.

National energy deficits and imports dependence are growing in South American countries since consumption increases and production has not risen at the same pace. Diversification is an answer to this challenge. Except Venezuela, all countries implement policies to facilitate the inclusion of non-conventional renewable energies. In that way States limit external dependence and avoid economic risks linked to oil price volatility. Considering the diversity of energy profiles, regulations, energy potentials and system conditions, diversification challenges faced by each country are very different. 


\section{DIVERSIFICATION:WHICH PROSPECTS FOR THE ENERGY TRANSITION?}

South American countries show energy and environmental concerns; they have launched plans, elaborated programmes and devised economic measures (Mastropietro et al. 2016) in order to promote non-conventional renewable energies and efficient energy use (Table 1). Clean development mechanisms triggered some initiatives. OLADE executes the Energy Efficiency Programme for Latin America and the Caribbean (PALCEE), which seeks to strengthen legal and institutional frameworks.

With regard to the incorporation of biofuel, South American countries have set legal ratios of bioethanol and biofuel in commercial fuels. They cover a wide spectrum from the Chilean objective of incorporating 2.5\% of biodiesel and bioethanol, to the implementation of a cut to $10 \%$ of biodiesel in Argentina (Bolivia set as a goal a mixture with $15 \%$ of biodiesel for 2015) and a cut of $25 \%$ of bioethanol in Brazil, where cars sold can use either gasoline or bioethanol.

There is an even higher diversity of initiatives encouraging other nonconventional renewable energies, particularly regarding electricity generation. Bolivia's Constitution (2009) explicitly states that the State will promote alternative energy, and in the Patriotic Agenda to the year 2025 it establishes objectives linked to renewable energy development (IRENA, 2015). The most frequent incentive mechanisms launched by the South American States are contracts with a special fee (guaranteed feed-in-tariff), additional bonuses (fixed percentage added to base energy price), obligation for participation or quota (mandatory percentage of renewable energy to be generated, set by the State, known as standard portfolio, renewable targets or renewable obligations), investment subsidy, tax exemption and tax incentives (Molina, Rudnick, 2011; Sauma, 2011).

By means of different mechanisms, Brazil has acquired a higher diversification level, with a significant participation of non-conventional renewable energies in the national primary and electric matrix. The capacity of governments to successfully carry out diversification depends on the existence of a long term prospect that guarantees continuity in public policies, adaptations to new challenges and financial support. In comparison, Argentina exhibits discontinuous energy policies, responding to particular circumstances and interests, and not to long term plans. The same could be said about Chile, that let the markets make decisions about 
Table I.

National Programs and legal aims for renewable energies development

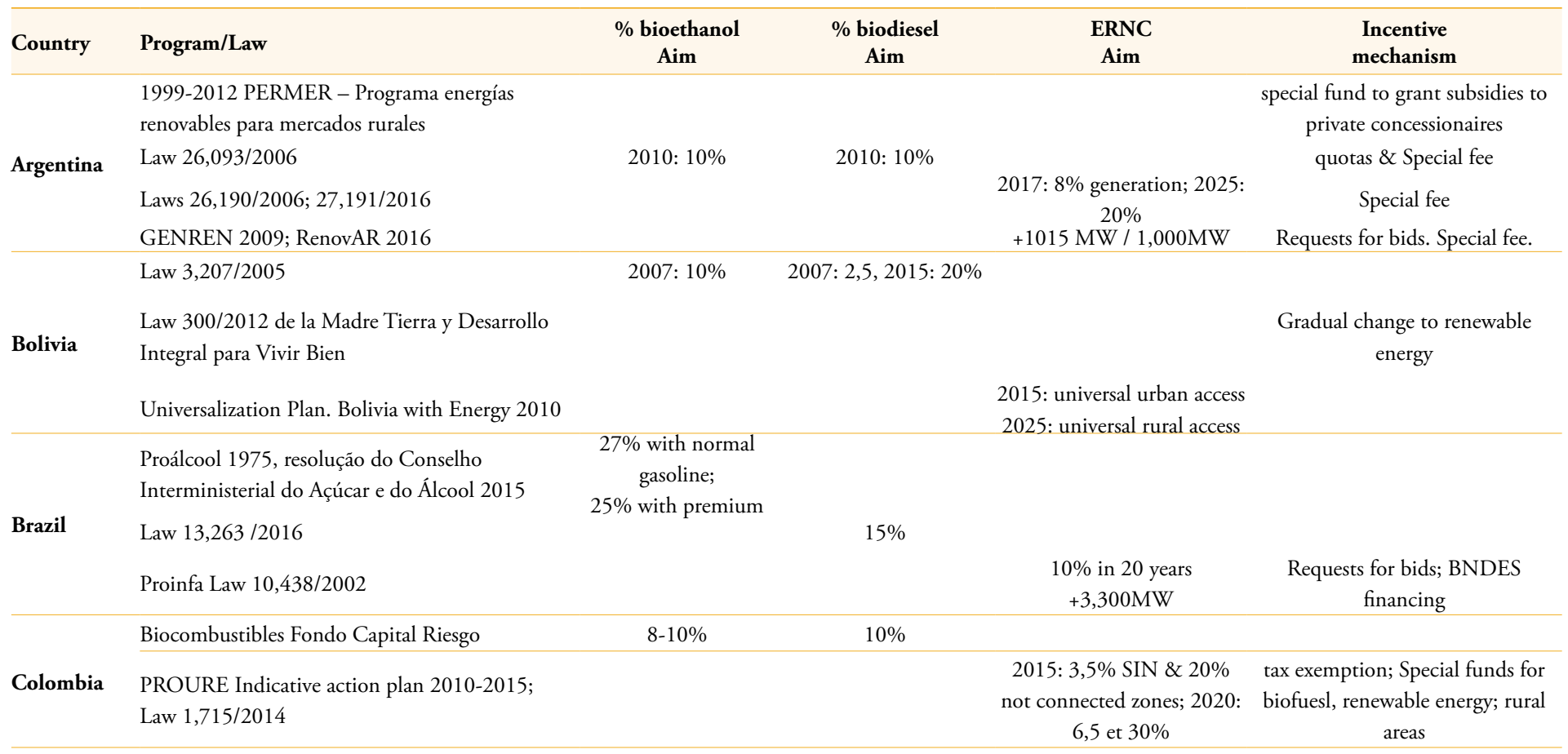


Table I.

Cont.

\begin{tabular}{|c|c|c|c|c|c|}
\hline Country & Program/Law & $\begin{array}{l}\text { \% bioethanol } \\
\text { Aim }\end{array}$ & $\begin{array}{l}\text { \% biodiesel } \\
\text { Aim }\end{array}$ & $\begin{array}{l}\text { ERNC } \\
\text { Aim }\end{array}$ & $\begin{array}{l}\text { Incentive } \\
\text { mechanism }\end{array}$ \\
\hline \multirow[b]{2}{*}{ Chile } & & 2008: 2,5 & $2008: 2,5$ & & \\
\hline & $\begin{array}{l}\text { Law 19940/2004; Law 20257/2008; Law } \\
\text { 20.698/2013; Decree 29/ } 2014\end{array}$ & & & 2024: $20 \%$ & $\begin{array}{l}\text { Quotas to big generators; Tax } \\
\text { exemption, Requests for bids }\end{array}$ \\
\hline \multirow[b]{2}{*}{ Ecuador } & & $5 \%$ & $5 \%$ & & \\
\hline & Plan Nacional Buen Vivir 2013-17 & & & $\begin{array}{l}\text { 2017: } 60 \% \text { including } \\
\text { hidroelectricity }\end{array}$ & feed-in tariff \\
\hline Peru & Decree $1,002 / 2008$ & & & $\begin{array}{c}\text { 5\%; } 2010+500 \mathrm{MW} \text { y } \\
\text { 1,314 GWh/year } \\
2011:+1981 \mathrm{GWh} / \text { year }\end{array}$ & Requests for bids. \\
\hline Paraguay & $\begin{array}{l}\text { Law 2,748/2005; Decree 2,998/2015; Law } \\
\text { 5,444/2015; Resol. 507/2017 }\end{array}$ & $\begin{array}{l}24 \% \text { min. } 25 \% \text { max. } \\
\text { flex fuel: } 85 \% \text { de } \\
\text { alcool y } 15 \text { gasoline }\end{array}$ & $\begin{array}{c}\text { 2007: } 1 \%, 2008: 3 \% \\
\text { 2009: } 5 \%\end{array}$ & & Fiscal incentives \\
\hline
\end{tabular}


energy mixes since the beginning of the 1980s, leading to serious shortages when Argentine failed to supply the expected quantities of gas. In Brazil, thanks to the constant support of the Proálcool Plan, the bioethanol industry grew, became competitive and does not need direct public help any longer. Co-generation from sugarcane waste represents an estimate potential of 14,000 MW. Incentives later focused on Proinfa - O Programa de Incentivo às Fontes Alternativas de Energia Elétrica (Decree 5,025/2004), which seeks to add 3,300 MW of capacity from non conventional sources. Within this program $800 \mathrm{MW}$ of wind power, 1,200 MW from small hydraulic power stations and 1,400 MW from biomass were contracted (144 projects in 19 States) (PROINFA 2013). Renewable energy is paid by ELETROBRÁS (a public-private company hold by the federal government at $70 \%$ ) with a special fee, for 20 years; and national industry receives strong support: long-term financing by BNDES is conditioned by equipment purchase with certain nationalization indexes. In 2016, Brazil accumulated 10,000 MW installed wind power capacity and it is in $9^{\text {th }}$ place in global ranking.

In proportion to the national market size, the most ambitious goal in South America was outlined by Uruguay (2008), which expected renewable energies to contribute with $50 \%$ of primary energy, and non-conventional energies to provide $30 \%$ of electricity by 2015 (MIEM). In consequence, UTE - Administración Nacional de Usinas y Trasmisiones Eléctricas - contracted $300 \mathrm{MW}$ of wind power and $200 \mathrm{MW}$ of biomass power capacity, guaranteeing to pay special fees for 10 years (2010 - 2011). Public and private investments in renewable energy increased. First wind farms started operating in 2008. Between 2014 and 2016, 1,200MW of wind turbine capacity were added. The country became one of the 29 world countries to have more than 1,000MW (17 in Europe; 4 in Asia - China, India, Japan and South Korea; 3 in North America - Canada, Mexico and the United States; 3 in South America - Brazil, Chile and Uruguay; South Africa and Australia) (GWEC, 2015). Uruguay passed from $1 \%$ of wind energy over the total generated in 2013, to $22 \%$ in 2016 http://portal.ute.com.uy/rrpp-novedades/la-nueva-energ\%C3\%AD.

Argentina targets a share of $20 \%$ of electricity from non-conventional renewable sources by 2025 . To achieve this, special fees are implemented in non-conventional renewable energy, and two Programs - GENREN and RenovAR - were launched. In each case, National State bid approximately 1,000 MW of installed capacity, guaranteeing the benefitted producers a contract with tax exemption and a special fee for 15 years. 
As in Brazil, Argentina and Uruguay, Peru has also made requests for bids of power and energy. This country intends to provide $5 \%$ of electricity to the national system coming from renewable sources, thus attracting mainly wind and hydraulic proposals.

Colombia intended to have $3.5 \%$ of non-conventional renewable electricity in the interconnected system by 2015 and $20 \%$ in non-interconnected areas, since these cover $66 \%$ of the national territory. These percentages are expected to increase to 6.5 and $30 \%$ by 2020 correspondingly. In order to encourage new sources development, the State sets incentives and tax exemptions, according to an Indicative Action Plan, to develop the Programme of Rational and Efficient Use of Energy and Other Non-Conventional Energy Forms, PROURE (2010).

Unlike other mentioned countries, which bid and hire power or renewable energy, or offer tax incentives, Chile obliges generators with capacities above 200MW, connected to Central and North systems, to contribute with an increasing percentage of non-conventional renewable energy, which must be $5 \%$ between 2010 and 2014 , and reach $10 \%$ by 2024 , an increase of $0.5 \%$ yearly (Act $20.257 / 2008$ ). This has been in force since 2010 and it has been accomplished. Chile has reached wind installations of almost 1.5 GW (GWEC, 2016)

Ecuador, instead, enables a part of $6 \%$ - maximum percentage- of the total installed power $(284.5 \mathrm{MW})$ in the national interconnected system for nonconventional renewable energy (excluding sugar factories projects or hydroelectricity) setting for 15 years, a fee mechanism that differentiates technology type, size and location - continental or Galapagos Islands.

Public programmes favour renewable energy growth. Parallel to them, several initiatives and undertakings aroused. Many of them also happen in the context of public-private partnerships that have made possible the development of small pilot projects using different technologies.

Projects multiply, especially in Brazil, where BNDES provides financing to renewable energy, and in Uruguay and Chile, where higher energy cost makes renewable sources more attractive than in other countries. In Argentina especially, high subsidies are granted to energy, which noticeably lower cost for users and increase public spending significantly. Social criteria and political calculus prevail over rational use efficiency parameters (Coviello 2012). 
In general, non-conventional renewable energies development is incipient, since programmes were defined at the beginning of 2000, but experiences have been positive. All these measures show that South American countries are willing to increase the share of renewable energy in the national mix, but they continue to work independently focussing on national issues and available sources, with little regard to cooperation with their neighbours. Except for the Brazilian programme of ethanol from sugar cane, South American countries prefer to use proven technologies, namely hydro power where building of new dams is possible, providing power networks with stable and cheap base load. Wind energy, which is currently the more mature technology, comes second. Solar energy is expanding. Small systems are used by isolated populations, far from networks. Large solar plants have been built or planned, especially in Chile, Uruguay, Argentina and Brazil, to cover increasing electric demand in national or regional systems. Other non-conventional sources, of which South America is richly endowed, are hardly considered. For example, little has been done to improve the use of bioenergy from forestry and agriculture, even in regions where the use of wood and charcoal is already high.

\section{THE MAZE OF INTEGRATION}

Integration of South America alternates advances and withdrawals phases. It has never succeeded to build up a unified geo-economic space, but it is always present on the regional agenda. UNASUR is the current expression of this process. Technical initiatives from the energy sector intend to boost the activity or guarantee supply safety. For example, improving power grids and interconnecting national and regional systems with physical infrastructures facilitate commercial exchanges between countries. They make easier the access to new sources, hydrocarbons reserves or places suitable for large scale hydroelectric dams. But this is feasible under clear and stable long term conditions of access to the resources. Better physical networks make the exchanges easier and can also help to cope with disruption of supply on a short term basis.

During the $20^{\text {th }}$ century, periods of active integration - the $1960 \mathrm{~s}$, the $1990 \mathrm{~s}$ - alternate with moments of conflicts between countries - the 1970s and part of the 1980s. During the first periods, political and technical organisms were created 
and operated actively to improve cooperation between countries, set commons standards and build infrastructures for exchanges. Conversely, during the harsher times of conflicts, existing alliances broke out, and countries made choices aiming at national independence with no regard to possible cooperation with their neighbours.

The heritage of the $20^{\text {th }}$ century consists in a set of political and technical energy integration institutionslisted in table 2, none of which has been suppressed, although some share common objectives. Some of these bodies are political, some are devoted to technical topics, like tariffs or infrastructures that affect energy markets. All of them are concerned with energy but only two are dealing exclusively with energy: OLADE (Latin American energy organization) and CIER (Commission of Regional Electrical Integration).

\section{Table II.}

Political and energy integration institutions

\begin{tabular}{|c|c|c|c|}
\hline Years & Acronym & Name & Objective \\
\hline $1960-1980$ & LAFTA & $\begin{array}{l}\text { Latin American } \\
\text { Free Trade Association }\end{array}$ & Create a free trade zone. \\
\hline 1969 & CAN & Andean Community & $\begin{array}{l}\text { Social and economic integration and cooperation. } \\
\text { http://www.comunidadandina.org }\end{array}$ \\
\hline 1973 & CARICOM & $\begin{array}{l}\text { Caribbean Community } \\
\text { and Common Market }\end{array}$ & $\begin{array}{l}\text { Foreign policy coordination and functional } \\
\text { cooperation. }\end{array}$ \\
\hline 1964 & CIER & $\begin{array}{l}\text { Commission of Regional } \\
\text { Electrical Integration }\end{array}$ & $\begin{array}{l}\text { Interconnection (privileging the use of } \\
\text { equipments and materials produced in the } \\
\text { region) }\end{array}$ \\
\hline 1973 & OLADE & $\begin{array}{l}\text { Latin American Energy } \\
\text { Organization }\end{array}$ & $\begin{array}{l}\text { "Promote agreements between its Member } \\
\text { Countries and carry out actions to satisfy } \\
\text { their energy needs by means of the sustainable } \\
\text { development obtained from the different sources } \\
\text { of energy." } \\
\text { http://www.olade.org }\end{array}$ \\
\hline 1980 & ALADI & $\begin{array}{l}\text { Latin American } \\
\text { Integration Association }\end{array}$ & $\begin{array}{l}\text { "To progressively merge in the creation of a } \\
\text { common economic place." } \\
\text { http://www.aladi.org }\end{array}$ \\
\hline 1991 & MERCOSUR & $\begin{array}{l}\text { Southern Cone } \\
\text { Common Market }\end{array}$ & $\begin{array}{l}\text { Progressive development of Latin America's } \\
\text { integration. It implies: goods, services and factors } \\
\text { free transit; establishing a common external tariff } \\
\text { and acquiring a common commercial policy; } \\
\text { coordinating macroeconomic and sectoral policies; } \\
\text { law coordination in the corresponding areas. }\end{array}$ \\
\hline
\end{tabular}




\section{Table II.}

Cont.

\begin{tabular}{|c|c|c|c|}
\hline Years & Acronym & Name & Objective \\
\hline 1994 & FTAA & $\begin{array}{l}\text { Free Trade Area of the } \\
\text { Americas }\end{array}$ & Eliminate barriers to trade and investment. \\
\hline 2000 & IIRSA & $\begin{array}{l}\text { Initiative for South } \\
\text { American Regional } \\
\text { Infrastructure } \\
\text { Integration }\end{array}$ & $\begin{array}{l}\text { "Advance in regional infrastructure modernization and } \\
\text { take specific actions to promote its integration and } \\
\text { economic and social development." } \\
\text { http://www.iirsa.org }\end{array}$ \\
\hline
\end{tabular}

2004

ALBA

2008

UNASUR

Union of South

American Nations

2011

America
Bolivarian Alliance for the Peoples of Our$$
\text { ur in }
$$

"Solidarity, genuine cooperation and complementarity among our countries, in the rational application and based on our peoples and their natural resources' wellbeing-including their energy potential-on the integral and intensive formation of human capital required by our development, and attending to our men and women's needs and aspirations."

http://www.alianzabolivariana.org

"Aimed at regional integration regarding energy, education, health, environment, infrastructure, safety and democracy. Its efforts are directed to strengthen South American nations union, under the acknowledgement of its regional objectives, social strengths and energy resources."

http://www.unasursg.org

Regional integration initiative formed by Chile, Colombia, Mexico and Peru to advance progressively toward free circulation of goods, services, capital and people; to promote higher growth, development and competitiveness for their economies and to become a platform for political, economic and commercial integration with global projection, especially over AsiaPacific.

http://alianzapacifico.net/

The creation of new institutions sometimes could be seen as a way to sort out obsolete mechanisms. In this succession of bodies, UNASUR represents a framework that encompasses all South America but not Latin America - Mexico, the Caribbean and central America excluded. It gathers CAN, MERCOSUR, 
Chile, Suriname and Guyana. Its official objectives are to act as a regional group in international relations, build up a Free Trade Area and achieve physical integration, particularly energy integration. Nevertheless UNASUR gave higher priorities to political issues rather than energy union.

Despite recurring initiatives regarding the creation of institutions, energy integration remains incomplete because during the greater part of the $20^{\text {th }}$ century, energy resources were considered strategic and a matter of national sovereignty. However, in the 1990s, energy was no longer considered as a strategic issue, it became a "commodity" that could be managed in a more efficient way by private companies operating on free markets. Energy integration processes were again encouraged. They responded to an increase in demand, associated with a rise in primary activities, a growth in households consumption and low energy efficiency of both sectors. Transnational companies that expanded throughout the continent were responsible for increasing energy supply. Natural gas became the keystone of integration: gas pipelines were built from Argentina and Bolivia to Brazil, Uruguay and Chile. Power grids were also improved. For example, Endesa laid two lines from Argentina to Brazil and another from a gas power station installed in the north of Argentina to the Norte Grande System in Chile. Its objective was to penetrate Brazilian and Chilean markets offering lower prices. For the same reason and to achieve even lower prices, its competitors built two gas pipelines parallel to the electric lines, in order to transport gas from Argentina and generate electricity in Chile.

Without a systematic long-term vision, extraction and export volumes regulation, oil and gas production levels were not sustainable in time. Facing shortages of gas and electricity, Argentina decided to limit its exports to neighbour countries. This decision led to conflicts between the State and the firms and fuelled tensions with Brazil and Chile that had become dependent of GNL imports. Reduction of gas exports from Argentina led to under utilization of gas lines, whereas Argentina always delivered small quantities of gas for household consumption. Similarly the nationalization of gas by the Bolivian government in 2007 caused a severe crisis with Brazil where facilities had been built relying on long term supply from Bolivia.

Electricity exports from Argentina through lines Garabí I and II supplied Brazil in critical years such as 2000 and 2001, but then they fell significantly. These lines have functioned in the opposite direction since 2004, to supply Argentina 
temporarily, in critical times or peak demand. Chile was not able to continue importing electricity from Salta (Argentina) and tried to develop new hydraulic or coal power stations in its territory, but these plants faced strong social protest. Paraguay claims to sell electricity produced in the binational dams Itaipú and Yacyretá, to third parties, such as Chile, and asks for higher prices for electricity sold to its partners.

States have taken unilateral measures regarding national interests. The non compliance of international treaties led to mistrust between partners. The inadequate treatment of asymmetries between countries, particularly the differences of weight and power between small and large countries, has diminished the political credibility of integration (Ruchansky 2013). Integration processes are getting slower, and new types of obstacles appear ${ }^{4}$. Nationalist policies put the State back in its roles of business maker, investor and planner. Energy companies have been renationalized, economic subsidies set up, and internal price control is enforced. South American States provide economic incentives or obligations to expand energy production and transport infrastructure. Energy supply is again a strategic topic, associated with ideas of self-sufficiency and sovereignty.

However, governments keep saying that integration must transcend commercial matters, and countries must ally with each other to reach a higher autonomy from the rest of the world. In this way, the contradiction between sovereignty and integration is solved by the idea that it is possible to overcome energy crisis and shortages achieving higher levels of integration. Consequently, governments and multilateral organisms launched an Action Plan for the Integration of Regional Infrastructure in South America (2000) - IIRSA - which includes the objective of developing "efficient regional energy interconnections, in a regulatory context promoting competence and free trade."

However, optimal solutions are not prioritized for networks design, neither on a national scale, nor on a regional one. Investments do not address social issues, local development or reliability improvement. Instead South American networks expansion are designed mainly to increase energy supply to mines, industry and metropolitan areas.

\footnotetext{
4 For example, in Brazil, since 2009, international interconnections will be subject to public
} concessions and have to be preceded by an international treaty. 
UNASUR has taken in charge the overarching programme of IIRSA to build large infrastructure that are seen as indispensible to achieve a higher level of connectivity and exchanges. Energy interconnections are key elements of the integration process 5 .

Although interconnection results in global benefits, distribution is often unequal in the interior of the region. Thinking about an equitable distribution requires a higher planning effort, which becomes more necessary since each country looks for more renewable energies, what demands technical coordination.

\section{FINAL REFLECTIONS}

South American countries exhibit a wide gamut of energy mixes and organization of energy markets, but they share the same need to improve security of energy supply and efficiency of energy use. Most have centralized systems that depend on fossil fuel and hydropower. The former ties local economies to international oil prices volatility, the latter makes them vulnerable to climate change and its consequences on rainfall and rivers. Economic growth entails the rise of energy consumption and the need to increase systems capacities. This context creates an opportunity to incorporate non-conventional renewable energies and distributed generation systems, which could facilitate supply to millions of people who still have no access to modern energy services. This could reduce high levels of technical losses and greenhouse gas emissions as well as favour local resources development.

Consequently, governments launched national programmes promoting nonconventional renewable sources and the creation of public-private partnerships. This also changes the ways of planning, operating and managing networks, which require a higher level of coordination and interaction among actors, in order to optimize the use of resources.

The low level of coordination among actors limits the scope of integration. In this sense, integration is achieved with minimum institutionalization, basic regulatory harmonization and arbitration schemes, according to national plans with a regional view, but without firm commitments. These are agreements

5 In 2005, a first meeting of Energy Ministers from the South American Nations Community was held; in 2007, the first UNASUR's Energy Counsel Summit took place; in 2009, the Guidelines Energy Integration Strategy were approved, along with an Agreement and an Action Plan. 
among governments privileging flexible and adaptable solutions for changing circumstances. Asymmetries among countries, their political views and national problems limit the scope of integration, which does not achieve a geopolitical unit.

\section{REFERENCES}

Apergis N. and J.E, Payne. (2015). Renewable Energy, Output, Carbon Dioxide Emissions, and Oil Prices: Evidence from South America Energy Sources, Part B. Economics, Planning, and Policy, 10(3).

Acquatella, J. (2008). Energía y cambio climático: oportunidades para una politica energética integrada en América Latina y el Caribe. Santiago de Chile: CEPAL.

BP. (2017). BP Statistical Review of World Energy June 2017. British Petroleum. Retrieved from: <http://www.bp.com/statisticalreview>.

Brasil. Programa de Incentivo às Fontes Alternativas de Energia Elétrica. Retrieved from: <http:// www.mme.gov.br/programas/proinfa/s.

Colombia. Ministerio de Minas y Energía. Uso racional de la energía. Retrieved from: $<$ http://www.minminas.gov.co/minminas/energia.jsp? cargaHome=38xid_categoria=213>.

Comisión Económica para América Latina (CEPAL). (2010). Gráficos vitales del cambio climático para América Latina y el Caribe. Santiago de Chile: CEPAL.

CIIER. (2013). Sintesis informativa energética de los países de la CIER Información del sector energético en países de América del Sur, América Central y El Caribe. Datos del año 2013. Comisión de Integración Energética Regional.Retrieved from: <http://www.cier.org. uy>.

Coviello, M.F., Gollán, J. and Pérez, M. (2012).Las alianzas público-privadas en energías renovables en América Latina. Colección Documentos de proyectos. Santiago de Chile: CEPAL.

De Nigris; M. and Coviello, M. (2012). Smarts grids in Latin America and the Caribbean. Santiago de Chile: ECLAC.

Droulers M. and Carrizo, S. (2011). Stratégies agro-industrielles autour de la filière des biocarburants au Brésil et en Argentine. Revue Géographique de l'Est [En ligne], 50(3-4).

Enerdata. (2017).Global Energy Statistical Yearbook 2017. Retrieved from: <https://yearbook. enerdata.net/total-energy/world-energy-production.html>.

Guyer, J. (2004). Niches, margins and profits: persisting with heterogeneity. African Economic History, 32, 173-191.

GWEC. (2016). Global wind report. Annual market update. Global wind energy council.

International Energy Agency - IEA. (2017). Key coal trends. Excerpt from: coal information. International energy agency. Retrieved from: <http://www.iea.org/>. 
IRENA. (2015). Renewable Energy Policy Brief: Bolivia; IRENA, Abu Dhabi

Kelman J. and Zaidan Gama, S. (2013). Energía Eléctrica - aprovechamiento de complementariedades entre países de América del Sur. In Sorj, B. and S. Fausto. Brasil y América Latina: ¿Qué Liderazgo es Posible? Edición del iFHC/Centro Edelstein,

Lara, I. F. (2012). Los obstáculos para la integración energética entre los países del Mercosur. Mural Internacional, 1.

Mastropietro, P., Batlle, C., Barroso, L.A. and Rodilla, P. (2016). The evolution of electricity auctions in South America Energy Sources, Part B. Economics, Planning, And Policy, 11(12), 1103-1110.

Molina J. D. and Rudnick, H. (2011). Expansión de la red para la integración de ERNC: ¿Oportunidades para América Latina?, Proc. of IX CLAGTEE, Mar del Plata, Argentina, 6-10.Retrieved from: <http://web.ing.puc.cl/ power/publications/deregulationsp.htm>.

Organismo Supervisor de la Inversión en Energía y Minería.Peru. Retrieved from: <http:// www2.osinerg.gob.pe/EnergiasRenovables/EnergiasRenovables.html>.

OPEC. (2015). Annual Statistical Bulletin. Organization of the Petroleum Exporting Countries. Retrieved from: <http://www.opec.org/opec_web/static_files_project/media/downloads/ publications/ASB2015.pdf>.

Prias Caicedo, O. (2010). Programa de uso racional y eficiente de energía y fuentes no convencionales - PROURE Informe Final. Plan de acción 2010-2015. Ministerio de Minas y Energía. Colombia Retrieved from: <http://www.minminas.gov.co/minminas/downloads/ UserFiles/File/ENERGIA/URE/Informe_Final_Consultoria_Plan_de_accion_Proure.pdf>.

Reddy A. and Goldemberg, J. (1990). Energy for the Developing World. Scientific American. Ruchansky, B. (2013). Integración eléctrica en América Latina: antecedentes, realidades y caminos por recorrer. Santiago de Chile: CEPAL.

Saguier, M. (2012). Socio-environmental regionalism in South America: tensions in the new development models. In Riggirozzi, P. and D. Tussie (ed). The Rise of Post-Hegemonic Regionalism: The Case of Latin America. Springer.

Sauma, E. (2012). Políticas de fomento a las energías renovables no convencionales en Chile. Temas de la agenda Pública, 52.

Servin, S. (2012). Argentina y los desafios del escenario energético global. Instituto del Servicio Exterior de la Nación. Catálogos. Buenos Aires. 



\section{IIRSA-COSIPLAN AND THE GARABI-PANAMBI HYDROELECTRIC COMPLEX IN THE HISTORICAL MISSIONARY TERRITORY}

\section{Ludmila Losada da Fonseca \& Aldomar Arnaldo Rückert}

\section{ABSTRACT}

The Initiative for the Integration of the Regional Infrastructure of South America (IIRSA), led by the Brazilian government, began in the 2000s to meet the demands and solve the lack of investment in infrastructure. In 2010, IIRSA was incorporated into the South American Infrastructure and Planning Council (COSIPLAN) of the Union of South American Nations (USAN). This initiative included in its portfolio old projects that have been left aside over time, one of which was the construction of two dams on the Uruguay River, on the border between Brazil and Argentina, whose project is currently called the Garabi-Panambi Hydroelectric Complex. The construction of dams on the Uruguay River dates back to the 1960s, when the urban centers increased their demand for energy. With this still existing demand, the projects continue to be agenda and emerge as possible promoters of regional integration. The implementation of Garabi and Panambi, which have not begun yet, have an impact on the host municipalities - already identified by the Movement of Dam Affected People (MAB) and the mayors of the host municipalities. This insertion of the IIRSACOSIPLAN through the project of the Hydroelectric Complex in the historical missionary territory reveals the imposition of a project due to the absence of dialogue between municipalities and the State, as well as the lack of dialogue with the civil society.

KEYWORDS Garabi-Panambi hydroelectric complex, regional integration, Integration of the Regional Infrastructure of South America. 
The South American subcontinent followed the post-Cold War world trend of forming regional trade blocks. This movement was motivated by a decreasing economic influence of great powers (Europe and the United States), compared to what happened during the Cold War (1945-1991), when they sought to hinder the socialist influence in the American continent (Hurrell, 1993). Thus, this new stage allows integration and cooperation through regional trade blocks ${ }^{1}$. Therefore, this would be an opportunity for underdeveloped countries to play a major role internationally. According to Santos (2011), globalization is the culmination of the capital internationalization process, due to the development of techniques, more precisely in the field of communication, and political actions that permit the emergence of this global market.

These initiatives interrupted a logic that for centuries pointed abroad, which prioritized bilateral relations or agreements with the developed countries that operated mostly with imperialist attitudes. As a result of this new scenario, the Initiative for the Integration of the Regional Infrastructure of South America (IIRSA) and the Union of South American Nations (USAN) are born, and the former is incorporated into the latter in 2010. In 2000, IIRSA was officially created in Brasília, and it sought to physically integrate the South American countries by the modernization of infrastructures, to promote economic and social development.

The South American Infrastructure and PlanningCouncil (COSIPLAN), which is a space for discussion on policies and strategies that aim to implement programs and projects for the integration of infrastructure, emerged from the importance of IIRSA to the integration proposed by USAN (IIRSA, 2012). Thus, USAN develops projects associated with COSIPLAN and, consequently, with IIRSA, which is its technical forum. This integration project seeks to integrate South America through this set of projects, namely on transportation (construction of different waterways, railways or motorways), communication and energy (power generation and interconnection). In order to achieve this, there are nine spatially distributed Integration and Development Axes (EIDs), which include the projects. The EIDs are divided into: Amazon, Andean, Capricorn, Guiana Shield, Paraguay-Paraná

\footnotetext{
1 According to Roseira (2011), regional blocks articulate different political and economic scales, creating a force contrary to globalization, seeking cooperation among the Member States.
} 
Waterway, Central Interoceanic, MERCOSUR-Chile, Peru-Brazil-Bolivia, and Southern Axis.

With this structure, IIRSA-COSIPLAN adds geopolitical projects in each space because, when an initiative that changes the use of a territory is implemented, a political and strategic use of it is also made, thus marking a power projection.

The Garabi-Panambi Hydroelectric Complex was chosen as the object of this study in order to understand how an IIRSA-COSIPLAN project is implemented and what its repercussions are. This project will be located on the Uruguay River, on the border between Brazil and Argentina, although it has not been started yet. This field research identified and interviewed the local territorial actors (mayors and social movements) in the municipalities that will host the hydroelectric plants: Garruchos and Alecrim, in Rio Grande do Sul State (RS), Brazil. They are both located in a region that, in this article, will be called Historic Missionary Territory, a space where a history marked by the presence of the Guarani people, European settlers, and Jesuit priests was constructed. Although not officially considered as a territory, this space still shows traits of a time when the limits of the States were absent.

\section{IIRSA-COSIPLAN}

Projects that aimed to integrate the infrastructure in South America were designed and theorized long before their implementation, and the IIRSACOSIPLAN initiative was no different. Hirt (2013) points out that the IIRSA theoretical framework is based on two studies. Infrastructure for Sustainable Development and Integration of South America, a study Eliezer Batista conducted in 1996 for $\mathrm{CAF}^{2}$, was based on the "geo-economic conception and technical analysis of the initiative" (Padula, 2014, p. 312). Un nuevo impulso a la integración de la infraestructura regional en América del Sur, a study carried out by IDB $^{3}$ was also used to formulate the IIRSA. It identified the problems that hinder trade growth in South America, structured the subcontinent in axes, aiming at a broader interchange with international economies (VITTE, 2006).

In the 2000s, after these studies were conducted and the discussion had begun, during the $40^{\text {th }}$ anniversary of IDB (Vitte, 2006), the presidents of South American

\footnotetext{
2 Andean Development Corporation - Development Bank of Latin America

3 Inter-American Development Bank
} 
countries met in Brasília to promote solutions to the logistical problems the subcontinent faced. According to Padula (2014), these deficiencies may be both due to geographical barriers and the absence of investments in this sector. The importance of solving these problems lays in the dependence of South American economies on the export of commodities, generating a need for large and dense infrastructure, especially for transportation, mostly the intermodal freight transport. Thus, as Vitte (2006) points out, IIRSA aims at a "new wave of modernization of productive infrastructures" (Vitte, 2006, p. 34), in order to strengthen the local economies within the international market.

The criticism to IIRSA-COSIPLAN is based on the fact that EIDs clearly ease the flow of commodities destined for export to Europe (via the Atlantic Ocean) and Asia (via the Pacific Ocean). If the only impetus were to integrate the subcontinent, the axes could connect the countries from north to south. On the other hand, it is noteworthy that, whenever a highway or other transportation modal is built, its use is not restricted to a commercial area; it can also be used for the transit of people, thus, at the same time, it is an advantage for a certain population. When the object of this study is considered, namely a hydroelectric power plant, this double advantage is also present: it is built aiming at increasing electricity generation to support the domestic - and South American - development, but it also creates jobs and changes the local reality. It is worth noting that the latter example implies some local damages, to be presented below.

The objective of the IIRSA-COSIPLAN is clear when the projects that comprise its portfolio are analyzed: they are mainly focused on the transportation sector (89\%). From the projects that are being implemented, 90\% of them are transportationoriented, and, from the concluded projects, approximately $40 \%$ were in the road transportation field (UNASUL, 2017). No other sector contributes more objectively to the flow of commodities than that aimed at transportation, majorly for the modernization and construction of new highways, thus strengthening the construction of bioceanic corridors and connecting productive areas to large centers and port cities, which function as flow points.

Some of the IIRSA-COSIPLAN projects are located in the historical missionary territory, which includes three integration axes: Mercosur-Chile Axis, ParaguayParaná Waterway Axis, and Capricorn Axis. Since it is a border region, it is strategic for the full integration of South America. 


\section{THE HISTORICAL MISSIONARY TERRITORY}

This study covers a perimeter that today comprises the border region among Argentina, Paraguay, Uruguay, and Brazil, and is defined here as a historical missionary territory. This territory is now left in the past, surpassed by current political divisions, but its ruins are vestiges of that historical moment, which was then a territory that housed about 100,000 Guarani people catechized by Jesuit priests. Those countries share a common missionary past in that - currently border region. In this same region, Brazil, Paraguay, and Argentina have developed important projects in the hydroelectric power generation sector, namely Itá, Itaipu, and Yacyretá; and soon Garabi-Panambi, whose construction is planned for the coming years. Currently, a new dispute is in progress in the historical missionary territory, which is no longer characterized by a polarization between the colonizers and the colonized (traditional communities), but a multipolarization of different interests and intentions of the territorial actors who play a part there.

When dealing with the history that pervades the historical missionary territory, and what it has left as a present heritage, it is essential to consider the cultural aspects of the indigenous society before and after the Jesuit Reductions. What remains of the time of the historical missionary territory is evident in the still existing ruins (Levinton; Snihur, 2011). This roughness ${ }^{4}$ marks a time in space when the territory was destined for the use of the natives and later for European exploitation; at that time, that region did not comprise the Nation States.

Marked by power struggle and the notion of limits, this territory requires deep understanding, even if there is no agreement as to its conceptualization. Etymologically, Lobato Corrêa reminds us that the word territory has its origin in the Latin terms terra and torium, meaning "land that belongs to someone." However, Corrêa states that belonging "is not necessarily related to land ownership, but to its appropriation" (Corrêa, 1998, p. 251). As historically demonstrated, the Guarani people effectively appropriated that land, made it their livelihood, and left their marks, which are present to date.

\footnotetext{
4 According to Santos (2009), roughness is what remains of the past as a form, a constructed space, a landscape, remains of the process of suppression, accumulation, superposition, with which things are replaced and accumulated everywhere. Roughness appears as isolated forms or arrangements. Although without an immediate translation, roughness brings us the remnants from divisions of labor that are already gone.
} 
This space is approached as a territory instead of being conceptualized as a region because, since the Iberian settlers arrived in the $16^{\text {th }}$ century, the former is characterized by power struggle. Santos and Silveira (2001) support this reflection when they state that a territory, seen as unity and diversity, is a central issue of human history and of each country, constituting the background for the study of its several stages and its present time.

Other authors also use the term territory to study this subject. For instance, Schallenberger (2007) states that the "Guarani territory" was limited from the control of space, and Santos and Rückert (2014) use the concept of "Missionary Transfrontier Territory," emphasizing that the territory is located in a border among Brazil, Paraguay, Argentina, and Uruguay. Another fact that supports the defense of the missionary territory is found in a study by Nogueira (2007), which uses the spatial delimitation of the missionary expansion introduced by Abou in 1996, as shown in Figure 1. The limits established by the area of activity of the Jesuit Missions, where the Thirty Peoples were located, support our understanding of it as a territory.

Although currently there is no conception of the existence of a missionary territory, since it has been surpassed by the existence of colonies and later by the Nation States (Brazil, Argentina, Uruguay, and Paraguay), this historical term reveals past issues and disputes that are alive and present to date. When the territory is considered as endowed with "[...] a plural, diverse, contradictory reality" (Rosière, 2007 , p. 24), it is understood that the territory now fragmented into Nation States can have this past territorialities, which can confront each other at a given moment.

The regions where the mission ruins are located are characterized by poverty, with limited resources, particularly due to their economic matrix (Nogueira, 2007). This fact makes the preservation of these historical and cultural antecedents even more important and relevant, as they are a fundamental source of income for their towns and population. It is worth noting that tourism, through exploration of the ruins and this missionary history, is an important tool for local development, which needs to be further encouraged by national governments, since South Americans are willing to know their own history and that of their neighbors, a fact supported by data from 2014 concerning the circulation of Brazilian, Paraguayan, and Argentinian citizens in these countries ${ }^{5}$. In this sense, with the construction of the

5 In 2014, 293,000 Paraguayans and 1.7 million Argentinians visited Brazil. 180,000 Brazilians and 300,000 Argentinians traveled to Paraguay. One million Brazilians and 600,000 Paraguayans visited Argentina (INDEC, 2014, Senatur, 2014, BRASIL, 2014). 


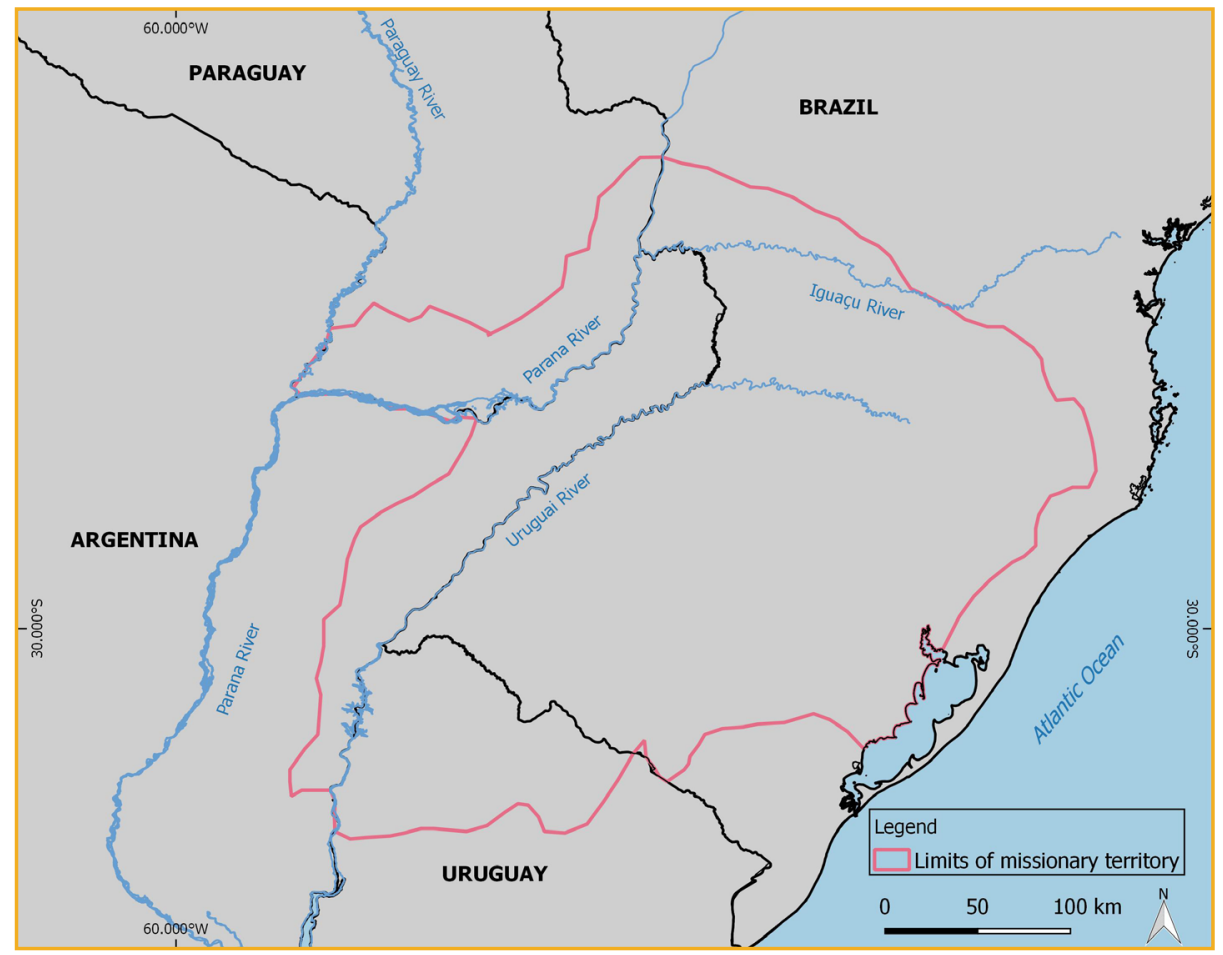

Figure I. Limits of the Missionary Territory.

Source: Abou (1996) apud Nogueira (2007).

hydroelectric complex, some kind of development could be expected for the region, as well as some tourism connecting the hydroelectric plants with the Jesuit ruins.

\section{ENERGY INTEGRATION: THE HYDROELECTRIC POWER PLANTS IN THE HISTORIC MISSIONARY TERRITORY}

The waters of the rivers that make up La Plata Basin were of great importance for the settlement of the Guarani people and the Jesuit Missions, as well as for the delimitation of the territory. At the time, the water resource was considered a good because it was necessary for the maintenance of life (for drinking, fishing, bathing). Currently, one of the main uses of a river is generating electricity through a dam.

Energy generation is the starting point and the essential condition for economic development, besides having paramount importance in the daily lives of populations. 
Energy integration may support the region's self-sufficiency in energy production, providing it with security and independence in this sector, enabling the countries to have greater power in the international system. In addition, this integration may solve the problems of energy deficit in countries such as Argentina, Chile, and Uruguay (Padula, 2014). The energy interdependence of the South American countries shows their state of maturity and pacifism.

Hydroelectric energy is a priority way to supply the region studied due to the water volume and its availability, and also because of the rivers' favorable physical characteristics. The investment in the construction of hydroelectric plants in Brazil arises from the greater participation of the country in energy production during the 1950s, under the discourse of promoting industrialization, since until then production was controlled by foreign companies. In this context, a bilateral agreement was signed between Brazil and Paraguay in the 1960s for the construction of Itaipu, the first major hydroelectric project in the historical missionary territory, whose investment totaled 27 billion American dollars. Another major hydroelectric power plant was Yacyretá, an Argentine and Paraguayan venture on the Paraná River, which began to be built in 1983, but was inaugurated only in 1998, costing 15 billion American dollars to both countries (EBY, 2009). This hydroelectric plant is strategic for Argentina because it supported the country's urbanization and, consequently, its increased energy consumption.

Despite the negative repercussions concerning the construction of hydroelectric plants (removal of local populations, deforestation, changes in river dynamics, environmental and social impacts), it is necessary to consider the vital participation of hydroelectric plants installed in the historical missionary territory for energy generation in the countries involved. In 2014, Itaipu supplied $75 \%$ of the energy consumed in Paraguay and 17\% of the energy used in Brazil (Itaipu Binacional, 2014). Likewise, Yacyretá currently accounts for $22 \%$ of the electricity consumed in Argentina.

The Uruguay River, where the Garabi-Panambi power plant will be installed, is located on the border among Brazil, Argentina and Uruguay. Historically, the boundary of these countries is characterized by the presence of hydroelectric dams due to its longitudinal waterway profile with waterfalls, which are useful for hydroelectric use. The river is $2,200 \mathrm{~km}$ long, its spring is located on the border between the states of Santa Catarina and Rio Grande do Sul, and its mouth is 
located on the border with Uruguay. The use of this important river has its historical records since the late 1960s, as suggests the first inventory study. It was only in 1976 that the border region was intended to build hydroelectric plants, making it necessary to update the studies.

This joint action between Brazil and Argentina, concerning the use of the Uruguay River, could only be carried out because of the existence of the "Agreement between the Government of the Argentine Republic and the Government of the Federative Republic of Brazil for the Use of Shared Water Resources in the Boundary Zones of the Uruguay River and its Tributary Pepiri-Guaçu", signed by both countries in the 1980s for the use of the river. It is assumed that the joint actions will take place between the state-owned companies designated as responsible for implementing the hydropower plants, namely ELETROBRAS and EBISA (ELETROBRAS, 2010).

\section{THE GARABI-PANAMBI HYDROELETRIC COMPLEX}

In 2008, the binational hydroelectric projects were resumed in the historical missionary territory to take advantage of the regional hydro potential, thus encouraging energy integration. As an example of this new moment, the initiative of the presidents of Brazil and Argentina at that time, Luiz Inácio Lula da Silva and Cristina Férnandez Kirchner, authorized the state-owned companies, respectively, Centrais Elétricas Brasileiras S.A. (ELETROBRAS) and Emprendimientos Energéticos Binacionales (EBISA), responsible for the generation, transmission and distribution of energy, to start feasibility studies for the construction of two new hydroelectric plants on the Uruguay River, on the border between both countries. This initiative will be achieved through the construction of the Garabi and Panambi plants, forming the Garabi-Panambi Hydropower Complex, which is part of the IIRSA-COSIPLAN project portfolio in the MERCOSUR-Chile Integration and Development Axis.

By means of inventory studies carried out by ELETROBRAS and EBISA, the Garabi dam will be built in the municipalities of Garruchos, Brazil, and Garruchos, Argentina, and the Panambi dam will be built in Alecrim and Panambí, respectively in Brazil and Argentina. Even considering the relevance of power generation for the subcontinent, and knowing that, currently, smaller dams are built to mitigate negative impacts, several territorial consequences from the construction 
of a hydroelectric plant are still predicted. The most mentioned ones are removal of people, reduction of biodiversity, the end of topophilic relationships, and uncertainties about the future.

In 2011, it was announced the resumption of binational hydroelectric projects in the historical missionary territory. At that time, the presidents of Brazil and Argentina, Dilma Rousseff and Cristina Kirchner, authorized the state-owned companies to start new feasibility studies. Thus, the Garabi and Panambi plants were designed for a total capacity of 2,200 MW, an estimated cost of 5.2 billion American dollars, having, if built, major direct and indirect impacts in the several municipalities of the region, as shown in Figure 2.

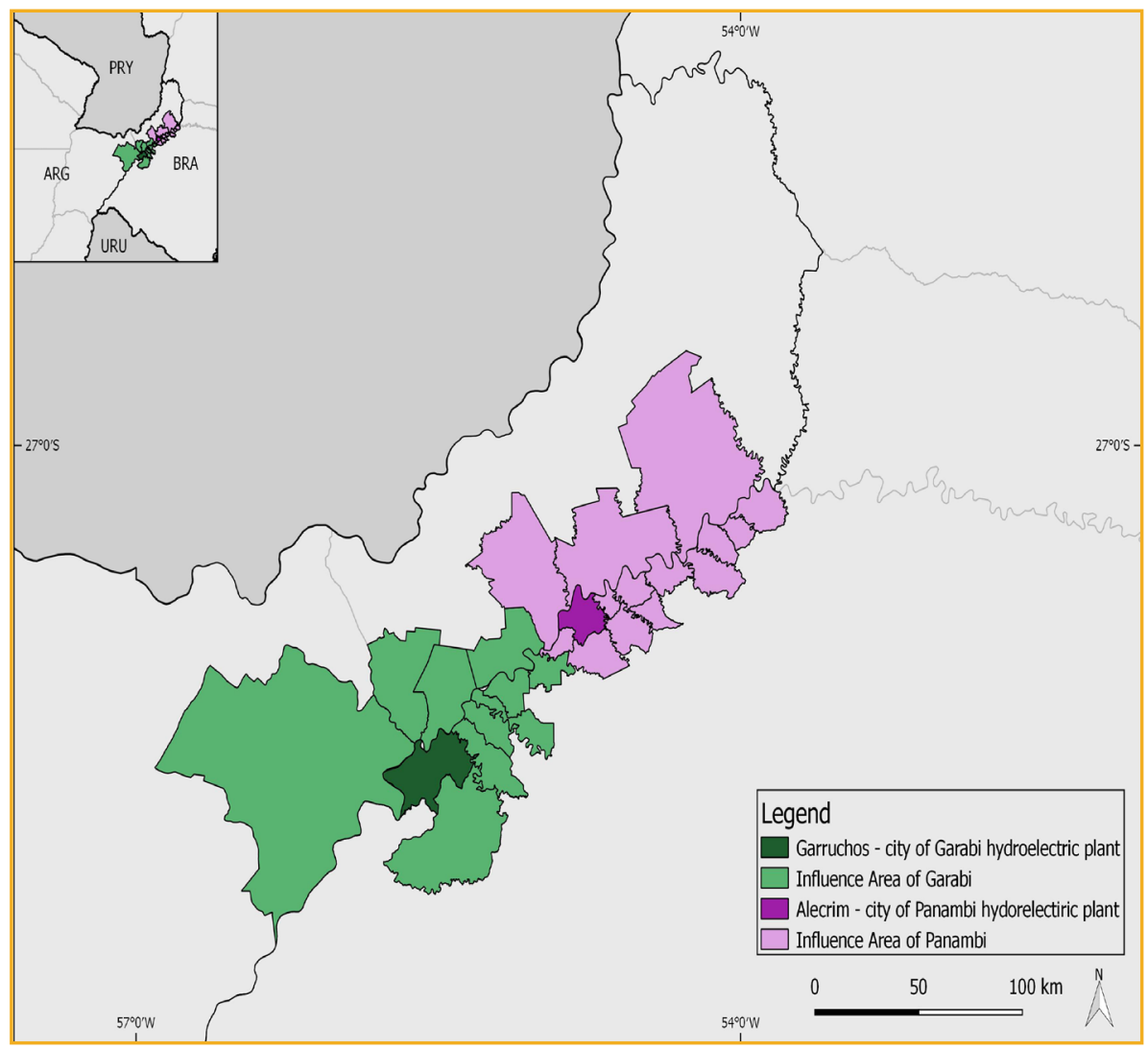

Figure 2. Area of Direct Influence of Hydroelectrics 
Now, to enhance the knowledge about the local reality, it is necessary to analyze the socio-economic profile of the Brazilian municipalities that will host the Garabi-Panambi Complex, Alecrim and Garruchos, located in the northwest of Rio Grande do Sul State, using data from the Brazilian Institute of Geography and Statistics (IBGE, 2016). It is noteworthy that, historically, the border region, which was characterized by poverty indices and scarce investment, is neglected by local governments.

The municipality of Alecrim, located in the northwest of Rio Grande do Sul, had an estimated population of 6,800 inhabitants in 2016, a figure that decreases continuously (IBGE, 2016). Due to urban hierarchy, the town assumes the role of a regional center, with only local influence. In addition, Alecrim disassociates itself from what occurs in the population standard, since most of its citizens reside in the rural area. It has a strong presence of agricultural business, especially soybean farming (IBGE, 2016). The municipal GDP per capita is a little more than 12 thousand Reais; the income of the majority of citizens is, however, between half and two minimum wages ${ }^{6}$ (IBGE, 2016). The local Human Development Index (HDI) is 0.672 - below the Brazilian HDI, which is considered medium by the UN.

Garruchos is a municipality that has shown a slightly decreasing population, from 3,234 in 2010 to 3,219 in 2015 (IBGE, 2016). The reality of the municipality is marked by the difficult access, since unpaved RS-176 is away from BR-285, an important road in the region. This makes the town growth unfeasible. Garabi I and Garabi II converters, which integrate an existing system between Brazil and Argentina to transmit electricity between both countries, are currently located in Garruchos.

Since the Garabi-Panambi Hydroelectric Complex is located on the border between Brazil and Argentina, it is also necessary to recognize the reality of the Argentinean localities. Corrientes and Misiones, characterized by the lowest HDI in the country, are the provinces that will be affected by the construction of the Hydroelectric Complex (UNASUR, 2014). Both provinces, respectively, have $14.2 \%$ and $12.7 \%$ of their territory protected by environmental laws, a number considered relevant when compared to data from Rio Grande do Sul, which is $3.2 \%$ (UNASUR, 2014).

6 In 2017, the Brazilian minimum wage is 937 Reais, which is around 295 American dollars. 
Although the Hydroelectric Complex is an old project, the IIRSA-COSIPLAN portfolio of projects assimilated both plants without modifications but separately. Thus, Garabi and Panambi have independent projects. Both are currently in the pre-execution phase. The IIRSA-COSIPLAN description for the Garabi project includes eight turbines, which spin generators to have a maximum installed power capacity of 1,152 MW. Also according to the inventory prepared in 2010, the reservoir flooded area would be $642 \mathrm{~km}^{2}$, with maximum level of 89 meters. Projects related to the installation of the hydroelectric plant are not presented in that report (IIRSA-COSIPLAN, 2017a). Besides, the Panambi hydroelectric power plant project includes seven turbines, with an installed power capacity of 1,048MW and a maximum level of 130 meters (IIRSA-COSIPLAN, 2017b). Along with Panambi plant, the project will cost about five billion dollars of public money, yet there is still no formal action in the pursuit of investments.

The implementation of the hydroelectric plants is slow. Although new studies started in 2010, only in 2014 IBAMA $^{7}$ issued the term of reference, a document necessary to start environmental studies, pointing out the items that these studies should comprise. From that moment, studies on the biotic environment of the region and engineering plans were carried out. At the end of that year, informative meetings were held with the local populations affected in Brazil. Currently, according to the project follow-up report, cultural and archaeological diagnosis studies have been carried out also on the Brazilian side ${ }^{8}$.

\section{A TERRITORY IN DISPUTE}

Considering the set of intentions of IIRSA-COSIPLAN and the implementation of new elements in the territory, it is necessary to reiterate the war of interests for territory use.In this sense, Hirt (2013) states that the central conflict of IIRSA lies in the socio-political and territorial issue. Territory is a space defined and delimited by and from power relationships. Therefore, existing conflicts over territory are common and constitute it.It is on the local scale that the conflicts and disputes over the territory use will occur, but with IIRSA-COSIPLAN this conflict is masked,

\footnotetext{
7 Brazilian Institute of Environment and Renewable Natural Resources.

8 In Brazil, the implementation of the hydroelectric plant is discussed judicially, generating, as an effect, the suspension of the environmental impact studies of the Panambi hydroelectric plant due to the repercussion it would bring to an environmental preservation area.
} 
because those who work locally for the countries in the name of integration are the construction companies responsible for the execution of the works.

In order to gain a better insight into the implementation of the project and its expected impacts, we considered the opinions of those who are on the "edge" of this process. Therefore, the territorial actors present at more local scales were considered, since, as Dietz (2008, p.112) states, "it is at a local scale [...] that the relations produced at the other geographical scales take place", as pointed out before.Tothisend, we interviewed municipal government representatives of the 2013-2016 legislature from the two host cities in the project and a representative of the Movement of Dam Affected People (MAB), social movement that legitimately represents those who will be affected by the dams.

During the research, the following items were identified as the main impacts: the environmental issue, the topophilic attachments and the process of deterritorialization', since it is understood that the implementation of GarabiPanambi unavoidably implies removal of people, action that was present in the implementation analysis of other hydroelectric projects.It is still noticed that, when the territorial actors of national and international scales decide on a project of local interference, due to an imposition, to an economic dynamics that is spatially materialized, it hardly ever fails to be executed, even if it was rejected by the population.

Given this idea, the next step is understanding the local territorial actors identified (MAB and mayors of the host cities) and their views on the implementation and the impacts of the project. $\mathrm{MAB}$ is considered a national and local territorial actor, who joins the territorial dispute when fighting for another model of development in which hydroelectric dams are not the only alternative for energy production. The Movement of Dam Affected People was already present in the cities affected by this Hydroelectric Complex when the first proposal was made in the decade of 1970 by demand of the affected people, and it was organized regionally.

For the MAB representative, the number of people affected will be higher than what is expected by those in charge of the studies made. The fact that dam constructions affect a large number of people is what supports one of the main

9 Removal triggers a process of deterritorialization characterized, according to Haesbaert (2003), by its social nature, which is linked to the increasing dynamics of socio-spatial exclusion. Deterritorialization is linked to the uprooting and weakening of territorial identities. 
demands of the movement: the existence of a national policy for dam affected people (PNAB).It would establish a protocol of procedures for the implementation of a dam. The representative of the movement also highlights that the hydroelectric plants are extremely profitable not only for the municipalities that will host them (Garruchos and Alecrim), because of the royalties received, but also for the companies that will control them, since the cost of the energy produced is much lower in comparison to its sales value, making energy production a profitable business.

The movement understands the fact that the Garabi-Panambi Hydroelectric Complex is associated with an integration project, since they see it as an initiative of IIRSA. However, within IIRSA there is no recognized space for demands or criticisms about the project: these claims are made to the state and federal government.

As representatives of the public administration at a more local level, the mayors of the municipalities (2013-2016 term of office) of Garruchos and Alecrim, site of the future Garambi and Panambi dams, were interviewed.

The mayor of the municipality of Alecrim points out the difficulty of projecting any type of territorial impact there can be in the town, as he considers that this will depend on several factors, such as: the work sites - still without definition - and the workers' settlement, the logistics required for construction, the demands for schools and for public health and the way the project will affect the public safety in the municipality. Thus, he considers that there is no way that such an undertaking will have no impacts in the municipality; however, he points out that the population of Alecrim can not have their access to public equipment hindered without any compensatory measures prior to this undertaking for the damage mentioned.

It was verified that the municipality of Alecrim has no participation in the implementation of the Panambi hydroelectric plant, had no compensation or obligation, nor was it consulted about hosting the hydroelectric dam, since this choice was due to the greater energy efficiency of a project which was considered of national interest. The fact that the Hydroelectric Complex is present in the IIRSACOSIPLAN project portfolio and, therefore, is associated with an integration process, was not explained to the mayor; however, he was aware that it was a binational project. 
The hydroelectric plant would only benefit the municipality if its implementation considered and respected the interests of the population that would be affected, and especially, as the mayor emphasizes, if the damage compensations were fair. There is a promise, along with the coming plant, of local development, with greater economic dynamics and more employment opportunities in the region. But the latter is not among the urgencies of the municipality, since the population is employed almost in its totality. The coming of the project will be beneficial for the municipality, in the mayor's point of view, if there is a planning focused on the socioeconomic issues, in which development opportunities can be generated.

For the former mayor of the municipality of Garruchos, the project is seen as a promoter of major changes in the municipality, with several impacts. What could not yet be said is whether these impacts will be positive or negative for the residents. He pointed out that at no time the municipality's point of view was consulted about receiving the hydroelectric plant, and thus, no specific compensation was required. Again, it makes evident the lack of protagonism of the local administrators concerning the implementation of the Hydroelectric Complex.

In addition to the infrastructure works, the paved road connection between Garruchos and the reconstruction of the affected areas, another benefit of the construction of the hydroelectric plant is the increase in the tax collection the municipality will have based on the use of the water from the Uruguay River. The mayor did not know that IIRSA-COSIPLAN was one of the promoters of the construction of the Garabi-Panambi Hydroelectric Complex, or that it had an international or binational character. This fact shows the distance between binational and municipal interests and the lack of communication among the entities involved.

\section{FINAL CONSIDERATIONS}

There is some difficulty and uncertainty about the future of studies that address regional integration. This is due to the fact that these initiatives are linked to a political will, which, in South American countries, may change in four or five years, due to government party changes. Thus, issues related to integration are not considered by a state program, where the national interest prevails, but only by those who are temporarily in power. However, these studies are considered to 
have great importance, since they reveal the intentions of the countries concerning integration, as well as their intentions for the territory. What is perceived, over the years and with the maturity of some integrationist processes, is that none of them effectively made it possible for the South American countries to change their roles in the international scenario, which continue to be agribusiness exporters, an inheritance of the colonial process. As for the importance in the geopolitical scenario, we noticed that it occurs in an individual and punctual way. USAN, in itself, does not have great importance in the international scenario as the European Union, for example. Those who take this place, in the mentioned context, are the countries with the greatest economic importance in the subcontinent, depending on the subject that is discussed.

As for the physical integration, the Garabi-Panambi Hydroelectric Complex project could contribute to the process of transbordering at the border between Argentina and Brazil. The hydroelectric dams, when they are built at the border, promote the shared use of a resource and, therefore, this greater interdependence, intensifying the process of integration in a real way, in a lived way. This approach is already beginning with the construction of the Hydroelectric Complex (with labor coming from the two countries) and involves its operation, with the participation of equally shared technical workforce. These exchanges provide greater communication, from the physical and informational points of view, among people, municipalities and localities, helping the process of transbordering.

The negative impacts of this implementation weigh on those who live around the rivers that will receive the hydroelectric dams and who usually depend on them for their subsistence. Most of them are small farmers who use the rivers for irrigation and fishing. The indigenous people are also very vulnerable, as they may be located along the banks of the rivers or in the reservations for the preservation of their culture and habits. In addition to the repercussions that are considered concrete, such as the loss of their lands and houses, the flood in riparian forests, there are also immaterial repercussions, such as the feeling of topophilia, the loss of neighborhood relationships that lasted for decades, the impossibility of returning to certain places because they no longer exist, the flooding of places considered sacred by the indigenous culture, the establishment of a new contact with the river.

According to the local actors, it is estimated that, with the increase in the circulation of people in the host municipalities (Alecrim and Garruchos), demands 
for public facilities should increase. The construction of schools, health centers and housing will become essential, albeit provisionally. Within this new set of demands, older demands of the municipalities (that were not met because they did not have the necessary visibility) may be present and take advantage of the moment.

It is noticed that the territory is still in dispute. The national and international interest takes precedence over the will and the wishes of the local residents. The conflict is also present locally among local territorial actors, through distinct views of MAB and mayors on the construction of the Garabi-Panambi Hydroelectric Complex. These different views, besides that of the federal governments, create in that space a dispute of intentionalities, in which the federal governments, organized by USAN, use their Power to impose a new use of this territory, disrespecting the citizens' relation with their space and with the traditional forms of use.

It is understood that the implementation of Garabi-Panambi fulfills clear objectives, which involve energy integration and support to the growth that the South American countries, mainly Brazil, have had, even though that was slowed by the world economic crisis of 2008. With the intention of building these hydroelectric plants, the National States' will to maintain the same development goals as those promoted in the 1970s is reaffirmed. Even if the Garabi-Panambi Hydroelectric Complex complies with these Argentine and Brazilian energy needs, it must be considered that local territorial actors must have broad participation in the project, not being on the sidelines, as they currently are. It is worth remembering that this lack of participation by civil society and government representatives has already been detected (SENHORAS, 2008). This is due, according to Mariano (2014), to the institutional organization of the institution that promotes integration. Thus, even if measures have been taken over time by IIRSA-COSIPLAN, the Federal Government and the state of Rio Grande do Sul, mechanisms to address this need are still urgent.

The integrative nature of the infrastructure promoted by IIRSA-COSIPLAN seemed to be, in the analysis made from the local actors' view, something of little importance, which was left aside; few people link the project to COSIPLAN or IIRSA. Thus, once again, IIRSA-COSIPLAN resembles a set of projects that fulfill national interests, and which sometimes manage to contribute to South American integration. Even though Garabi-Panambi are now linked to an integration process, they were not originally designed in this perspective, as they were rather 
part of a binational agreement between Argentina and Brazil. Therefore, it is the national interests that pervade this megaproject, leaving aside what is claimed by USAN concerning the integration of peoples and the respect for cultures. As for its implementation, the Hydroelectric Complex keeps the same distance with the local communities (and their wishes, doubts and future perspectives). As for the impacts, what can make them more lenient, if this is possible, is precisely a real rapprochement, creating a space for effective dialogue with the population.

IIRSA-COSIPLAN, through Garabi-Panambi, can modify the historical missionary territory. The first transformation occurs with the reaffirmation of old projects that are still considered in its portfolio, supporting the affirmation that IIRSA-COSIPLAN does not break the model within which the subcontinent was thought in the past. The other changes are present in the alteration of territory use, in the destruction of archaeological sites from the time of Jesuit Reductions, and alter the relation of the population with the river (feeling of belonging), as well as the intensification of the flows in the subcontinent.

The missionary territory, which in the past was used for the indigenous way of life and subsistence, and was the meeting point of Western and local cultures when the territory was produced, today is used to fuel a capitalist society, which sees in its demand for energy consumption reason enough to change the uses of places that not even have access to basic infrastructure. Different times and functions have accumulated in this territory where integrationist projects and their physical and energetic articulations are confronted with the reality of marginalization of the Guarani indigenous peoples. The tradition, culture and way of life of these traditional peoples are revealed even in the territory toponyms, but their fates seem to find no space in the geopolitical analyses of integrationist processes. 


\section{REFERENCES}

Brasil. (2014). Ministério do Turismo. Anuário Estatístico de Turismo.

Centrais Elétricas Brasileiras S. A. (ELETROBRAS). (2010). Estudo de Inventário do Rio Uruguai no Trecho Compartilhado entre Argentina e Brasil. Novembro.

Corrêa, R. L. (1998). Territorialidade e Corporação: um exemplo. In Território: Globalização e Fragmentação. 4." ed. Editora Hucitec: São Paulo.

Costa, W. M. (1997). O Estado e as Políticas Territoriais no Brasil. 6. ed. São Paulo: Contexto.

Dietz, C. I. (2008). Cenários Contemporâneos da Fronteira Brasil-Argentina: infraestruturas estratégicas e o papel dos atores no processo de cooperação/integração transfronteiriça. Porto Alegre: UFRGS.

Entidad Binacional Yacyretá (EBY).(2009). Desarrollo Social en ambas Márgenes: El Plan de Acción para Reasentamiento y Rehabilitación (PARR).

Haesbert, R. (2003). Da Desterritorialização à Multiterritorialidade. Boletim Gaúcho de Geografia, 29, 11-24.

Hirt, C. (2013). O Papel do BNDES nas Políticas de Desenvolvimento e Integraçáo Regional. Revista Brasileira de Geografia e Econômica, 3.

Hurrell, A. (1993). Os blocos regionais nas Américas. Revista Brasileira de Ciências Sociais, 8, 98-118.

Instituto Brasileiro de Greografia e Estatística (IBGE). (2016). IBGE Cidades.

Instituto Nacional de Estadística y Censos (INDEC). (2014). Turismo Internacional.

Iniciativa para a Integraçáo da Infraestrutura Regional Sul-Americana (IIIRSA). (2012)

Conselho Sul-Americano de Infraestrutura e Planejamento (COSIPLAN).

IIRSA-COSIPLAN. (2017a). Ficha de Proyecto de la Construcción de Planta Hidroeléctrica de Garabi. Retrevied from <http://iirsa.org/proyectos/detalle_proyecto.aspx?h=313>

IIIRSA-COSIIPLAN. (2017b). Ficha de Proyecto de la Construcción de Planta Hidroeléctrica de Panambi. Retrevied from <http://iirsa.org/proyectos/detalle_proyecto.aspx?h=1327>

Itaipu Binacional. (2014). O que representa a energia da Itaipu para o Brasil e o Paraguai? Itaipu Binacional.

Levinton, N. and Snihur, E. (2011). El Porvenir de Misiones. Buenos Aires: Contratiempo Ediciones.

Mariano, M. (2014). O Papel do Brasil na Integração da Infraestrutura da América do Sul: Limites Institucionais e Possibilidades de Mudança. In NETO, Walter (org.). O Brasil e Novas Dimensôes da Integração Regional. Rio de Janeiro: IPEA, p. 230-290.

Nogueira, C. R. D. (2007). O Turismo, o Reencontro e a Redescoberta da Região das Missóes. São Paulo: USP. 
Padula, R. (2014). Da Iirsa ao Cosiplan da UNASUL: a Integração de Infraestrutura na América do Sul nos anos 2000 e suas Perspectivas de Mudança. In: O Brasil e Novas Dimensóes da Integração Regional. Rio de Janeiro: IPEA, p. 291-352.

Rsoseira, A. C. (2011). Nova Ordem Sul-Americana: Reorganização Geopolítica do Espaço Mundial e Projeção Internacional do Brasil. São Paulo: USP.

Rosière, S. (2007). Les acteurs géopolitiques. Géographie politique \& Géopolitique. 2 é édition. Paris: Ellipses Édition.

Santos, C. R. and Rüickert, A. A. (2014). Turismo, Fronteira e Território: Uma Análise do Território Transfronteiriço Missioneiro.In Anais do I Congresso Brasileiro de Geografia Política: Geopolítica e Gestão do Território, 2014. Rio de Janeiro, p. 1105-1016.

Santos, M. (2009). A Natureza do Espaço: Técnica e Tempo, Razão e Emoção. 4. ed. São Paulo: Edusp.

Santos, M. (2011). Por uma Outra Globalização: do pensamento único à consciência universal. Rio de Janeiro: BestBolso,

Santos, M. and Silveirra, M. L. O. (2001). Brasil. Território e sociedade no início do séc. XXI. Rio de Janeiro: Record.

Schallenberger, E. (2007). Estudos missioneiros: Temas e abordagens. In: São Francisco Xavier: nos 500 anos do nascimento de São Francisco Xavier: da Europa para o mundo 1506-2006. Porto: Centro Interuniversitário de História da Espiritualidade, p. 27-56.

Secretaria Nacional de Turismo (SENATUR). (2014). Turistas a Paraguay por Nacionalidad.

Senhoras, E. M. (2008). Regionalismo transnacional e integração física: um estudo sobre a iniciativa de integração da infraestrutura sul-americana. Campinas: Unicamp.

Unión de Naciones Sudamericanas (UNASUR). (2014). Cartera de Proyectos 2014. Retrevied from: <http://www.iirsa.org>.

Unión de Naciones Sudamericanas (UNASUR). (2017). União das Naçóes Sul-americanas. Cartera de Proyectos. Retrevied from <http://www.iirsa.org>

Vitte, C. C. (2006) Integração, soberania e território na América do Sul: um estudo da IIRSA. Revista Terra Livre, 2(27). 


\section{THE IMPERFECT SYNTHESIS BETWEEN DEVELOPMENT AND DEFENSE IN BORDER MANAGEMENT IN LA PLATA BASIN}

\section{Flávia Carolina de Resende Fagundes}

\section{ABSTRACT}

The guarantee of security necessarily passes through the development dimension, just as this is also a fundamental condition for the continuation of economic activities. Although this interdependence is evident, when we look at policies towards Brazilian borders, we note the mismatch between development and security bias, since the latter has dominated the agenda, overlapping the other dimensions. Thus, in this article we will analyze the links between security and development, as well as the actions in these spheres in the borderland, focusing on the context of La Plata Basin, more specifically the Iguaçu cross-border region.

KEYWORDS Defense, Security, Development, Borderland. 
The guarantee of security necessarily passes through the development dimension, as this also depends on a secure atmosphere for the continuation of daily activities. Although this relationship of interdependence is well known, in the management of the Brazilian border there is a mismatch between these dimensions.

In recent years, the border has been increasingly prominent on the political agenda. This is mainly due to issues related to public security, with a logic oriented towards the problems that afflict large urban centers, such as Rio de Janeiro and São Paulo, often without considering the particularities of the borderland.

Consequently, this movement towards the securitization of Brazilian borders has in some extent to overlap a more positive agenda related to borders, with themes such as public policies of development and regional integration.

Considering this, we will analyze these processes in the Tri-Border between Argentina, Brazil, and Paraguay, since this is an important area of the integration in La Plata Basin, as well as a border region differentiated by its regional economic role and security dynamics highlighted in the national regional and international context.

Thus, in this article, we discuss the relationship between the dimension of development and security in the prevention of the so-called new threats, a subject not yet much discussed in Brazil in a systematic way. In addition, we seek to assess whether there are links between the main initiatives in the area of security and development in the borderland.

\section{THE RELATION BETWEEN SECURITY AND DEVELOPMENT}

The discussion of the relationship between security and development is not new, but this agenda became more strongly discussed after the 2000s, focused mainly on the post-conflict environment, but this dynamic also plays an important role in public security contexts and guarantee of sovereignty.

The profound process of transformation of the concept of security drove this debate. A state-centered concept of security has given space to a new conceptualization, moving from a state-centered view to a more individual-related approach (Klingeibel, 2006). As we can see in Barry Buzan's (1983) definition of security as "the necessary condition to allow the survival and coexistence of the individual who is satisfied in each culture in accordance with the mechanisms established by it to establish and protect it". 
Nevertheless, the concept of development also moved away from the macro level to focus on the micro, the individual. Currently, development encompasses several dimensions, ranging from human rights to environmental sustainability, as well as from economic growth to governance (Tschirgi, 2006).

In this way, it made explicit that a peaceful environment is a necessary condition for development, in other words, these dimensions are intrinsically interdependent. According to the Ministério da Integração Nacional-Ministry of National Integration (2009), the growth of tension and social exclusion is an obstacle to the sustainable economic development of the nation, since it promotes violence, which can, and in many cases destroys the formation of social and physical capital as well as the flow of internal and external investments.

Hence, the perverse side of globalization tends to affect most heavily the poorest because of its low capacity to enter into the highly competitive dynamics of global markets. Thus, low or negative growth in marginalized regions, high levels of unemployment (especially among young people), disorderly urbanization, poverty, ease movement of drugs, arms, and finance across borders, poor governance and effectiveness of the law are problems that feed each other, providing fertile ground for violence (Tschirgi, 2006).

In this regard, former UN Secretary-General Kofi Annan in his report In Larger Freedom quoted by Tschirgi (2006) notes that "not only development, security, and human rights are imperative, they reinforce each other."

Therefore, as we can see from the arguments demonstrated above, the dimensions of development and security are interdependent in ensuring the wellbeing of populations, which creates the need for synergies in the formulation and implementation of both policies.

However, if national development policies are poorly integrated, articulations with security policies appear to be even more problematic. National security institutions tend to focus more on traditional frameworks than on a broader understanding of human security and prevention strategies (Tschirgi, 2006). Notwithstanding, the concepts of security and development are fluid and elusive, which also hinders coordination between these two spheres since it raises questions such as where to cooperate? To what end?

Thus, there is still concern that the security agenda will overlap the development dimension in the formulation of joint strategies, leading to the subordination of actions aimed at development to security.

However, Klingebiel (2006) argues that it is vital to identify situations and spheres, where the closest coordination and even in some cases joint planning, action, and monitoring are more appropriate and effective. 


\section{THE DEVELOPMENT AND SECURITY POLLIES FOR THE BRAZLLLAN BORDERLAND}

The borderland is the $150 \mathrm{~km}^{1}$ zone within the national territory from the international borderline, it corresponds to approximately $27 \%$ of the territory, extending through 11 states and 588 municipalities along 16,886 km, being 7,363 $\mathrm{km}$ in dry line and 9,523 km in rivers, lakes, and canals, bordering 10 countries, it has a population of about 10 million inhabitants. It is one of the largest borderlands in the world.

Comparing with international examples, the Mexico-United States of America border extends for $3.141 \mathrm{~km}$, one of the most controlled borders in the world, and still a very problematic one. In this sense, the Brazilian borderline is almost 6 times longer than the one of U.S.A-Mexico, along with very different regional realities, what it is very challenging for any administration. The map on the next page exemplifies the magnitude of the Brazilian borderland.

It is worth noting that this region has peculiar characteristics in comparison to the rest of the country. Such differentiation is due in part to the way in which the territorial occupation of Brazil occurred, focused mainly on the coast and with the concentration of economic activities in this space.

The border region, until the stabilization of the Brazilian borders, was seen as a zone of containment and guarantee of the integrity of the territory, thus having a low economic insertion in the rest of the country. However, with the consolidation of borders, this area continued to be seen through a security bias and was characterized by marginal economic insertion (with the exception of a few matters), difficulty in accessing public goods and services, lack of social cohesion, lack of compliance with citizenship and problems peculiar to border regions.

In this context, the populations of these regions often have closer contacts with the other South American countries than with their own country, especially in the twin cities, with their own models of organization amidst the difficulties generated by the complex existing legal framework (TCU, 2014).

\footnotetext{
1 The current regulation of the borderland was formulated in 1979, during the government of João Baptista Figueiredo, the last administration of the military regime, by Law 6,634.
} 


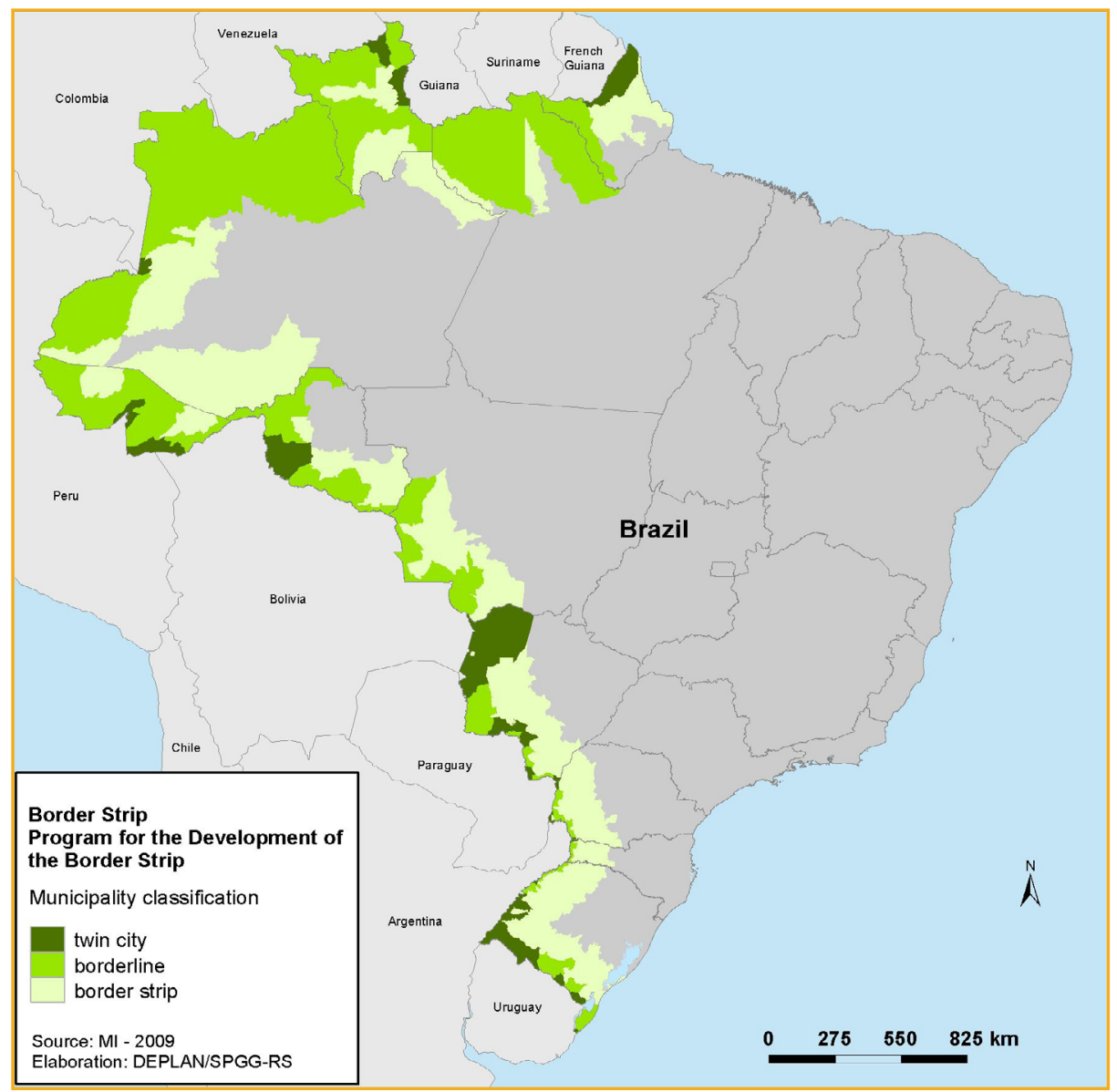

Figure I. Map of the Brazilian Borderland Source: SPGG/DEPLAN-RS

Therefore, the borderland is a paradoxical space. If on the one hand it is characterized by being the limit, where the state jurisdiction ends, a peripheral zone, on the other hand it is a reaffirmation space of the State, a synonymous of its affirmation and of its absence (Dorfman; Cardin, 2014).

These peculiarities led this space to impose singular challenges to the State, demanding specific policies. In this sense, we will analyze the initiatives of Brasília to strengthen the cohesion and security of the borderland. 


\section{PROMOTION PROGRAM OF THE DEVELOPMENT OF THE BORDERLAND}

The issue of planning for development was abandoned with the ideology of neoliberalism in vogue in South America in the 1990s. However, by the end of the decade, this issue returned to the political agenda, materializing in public policies in the early years 2000 .

Considering that, the development agenda and the search for mitigation of regional inequalities are fundamental in a country as diverse and vast as Brazil. The country has great regional asymmetries that still present challenges to the society in reducing inequalities (Ministério da Integração Nacional, 2009).

In the year 2003, discussions on territorial planning and regional development policies began at the federal level. In this context, two proposals were developed: the National Policy for Territorial Planning (PNOT acronym in Portuguese) and the National Policy for Regional Development (PNDR acronym in Portuguese). Of these proposals, only the National Policy for Regional Development advances, while PNOT $^{2}$ had no continuity, although its workshops have generated a significant knowledge about territorial planning.

In 2007, through Decree No. 6,047, the National Policy for Regional Development was instituted, under the coordination of the Ministry of National Integration, with the objective of reducing regional inequalities and activating the potential development of the regions in the country.

In order to better approach the specificity of some areas, the Regional Planning Secretariat implemented three subsidiary programs to the policy: the Program for the Promotion of Sustainability of Sub-Regional Spaces, the Program for the Integrated and Sustainable Development of the Semi-Arid and the Promotion Program for the Development of the Borderland (Ministério da Integração Nacional, 2009).

In this sense, the Promotion Program for the Development of the Borderland has tried to mitigate the deficient economic insertion of this region, aiming to:

\footnotetext{
2 A Territorial Planning Policy presupposes a wide scope, involving several dimensions for territorial planning, which makes its achievement extremely difficult.
} 
Promote the development of the Borderland through its physical, social and productive structure, with emphasis on the activation of local potentialities and articulation with other South American countries. With this purpose, it seeks to implement initiatives that respect the diversity of the region and follow the guidelines of the National Policy for Regional Development PNDR (Ministério da Integração Nacional, 2009).

Thus, the program aimed to strengthen the processes of change from the stimulus to the formation of networks of local actors, strengthening new dynamic axes of the economy. In addition, it sought to articulate the public policies of the three spheres of government, as well as to draw the attention of congressional representatives to channel resources from amendments to the General Budget of the Union as a financial reinforcement to the elaboration and implementation of regional development actions in the borderland (Ministério da Integração Nacional, 2009).

One of the main challenges that have constrained the advance of the program was the prioritization of the border security agenda, largely due to how the border is understood, seen as concentrating and propitious regions for the practice of various crimes, notably drug trafficking, prostitution, violence and various human rights abuses. Nevertheless, it is not understood as a region with the singularity of catalyzing subregional development processes and regional integration (MI, 2009), as well as an important laboratory of regional integration.

One of the aspects of the Promotion Program for the Development of the Borderland was the institutional strengthening in the border area. In this sense, it proposes the articulation with the actions of the Interministerial Working Group, which strengthens the Borderland, based on the integrated action in line with the necessary infrastructure for the development of the region. Moreover, support to sub-regional development forums; encouraging the articulation of Development Forums with Committees and Border Commissions; and local and integrated organization, including the participation of neighboring countries - creation or strengthening of border committees (Ministério da Integração Nacional, 2009).

As we can observe, the Promotion Program has proposed very broad actions at the borderland. However, the program did not have an adequate allocation of resources, what lead to insufficient results. The Pluriannual Plan for 2012-2015 
grouped various federal programs and actions into 65 strategic policies, thus the program was diluted within the South American Integration Policy (Neves, 2016). Nevertheless, the creation of the Permanent Commission for the Development of the Borderland represents the end of the Promotion Program for the Development of the Borderland as a program.

Henceforth, even though the results of the Promotion Program for the Development of the Borderland are modest, and the PNDR seems to be undergoing a weakning, it is important to keep in mind the need for actions aimed at improving the living conditions of these populations and not only actions to repress transnational crime.

\section{STRATEGIC BORDER PLAN AND THE NATIONAL STRATEGY FOR PUBLIC SECURITY FOR BORDERS}

In general terms, both the zones and the borderland are directly linked to the functional profile of the borders (Silva, 2013), and this has undergone transformations throughout the 2000s. In this sense, in Brazil in the last decades, we have observed that the borders have gained increasing prominence in the Brazilian political agenda. This process generated new forms of political management of border spaces, by the federal government (in articulation with the state governments) that combine elements of affirmation of sovereignty and of territorial defense with specific concerns regarding public security - such as drug and arms trafficking, contraband, etc. (Alvarez;Salla, 2013).

On this subject, such initiatives are also responses to the political tensions that lead to the debate about the abandonment of the border, the need to defend borders, closer control of transnational crimes and illegal economic flows (such as smuggling and drug trafficking) and population. In this sense, in addition to the demands for a greater presence of the Armed Forces in the borderland, reaffirming its role of defending the sovereignty of the State, control over the flows of people and goods has become one of the most important targets of the tensions in the political debate on borders in Brazil (Alvarez; Salla, 2013).

Within this logic, when we study the documents of the National Defense Policy of 1996, 2005 and their revision, we perceive that the border appeared with greater focus from one version to the other, highlighting mainly the need to vivify the border. Concerning this, there has also been an increase in the attributions of the Armed Forces in this space, being these endowed with police power in the borderland. 
Because of this process, in 2011 the Strategic Border Planwas launched, with the general objective of preventing, controlling and repressing cross-border crimes and crimes committed in the Brazilian borderland. The decree established cross-border crimes as trafficking drugs, arms and people, smuggling, eviction and illegal export of vehicles, environmental and homicides (Brasil, 2011).

In the scope, Operation Ágata was launched, being the most important operation, currently on the border, under the coordination of the Ministry of Defense and the Joint Chiefs of Staff of the Armed Forces. The execution is done by the Navy, the Army and the Brazilian Air Force (Força Aérea Brasileira, 2013). In addition to the Armed Forces, about 30 federal, state and municipal agencies participate in the operation, among ministries, regulatory agencies, and oversight and security agencies.

Also within the plan, there were smaller operations, such as the Operation Sentinel, coordinated by the Federal Police and formed by the Federal Highway Police, the National Security Force and the Rio Grande do Sul Military Brigade (Polícia Federal, 2012). This is a continuous operation differently from the Operation Ágata, which happens sporadically. In addition, there are other operations deployed by the various federal and state security agencies.

The strategic design of the Strategic Border Plan envisaged that Operation Ágata would be a momentary pressure on cross-border crimes, reducing the supply of illicit drugs and disrupting smuggling supply networks, at which point the Ministry of Justice, with a judicious use of intelligence, will employ its police departments in the context of Operation Sentinel.

Operation Ágata has among its objectives: to promote the integration of efforts between the Ministry of Justice and the Ministry of Defense in the borderland, including the participation of other federal, state, municipal and non-governmental bodies; ensure the legitimacy of the actions undertaken by Brazil in the national and international spheres. Moreover, strengthen state presence in the border region and promote integration with neighboring countries to strengthen prevention, control, enforcement and repression of cross-border crime.

In the spectrum of public security,in 2012, the National Strategy for Public Security at the Border was proposed in conjunction with the Strategic Border Plan. This plan seeks to create mechanisms to increase the effectivity of the coordinate actions of public agencies in the borderland, with the aim of reducing crime and illicit trafficking, being coordinated by the Ministry of Justice, through the National Secretariat of Public Security. 
Therefore, we can see that these plans aimed to affirm the presence of the State in this region, the greater effectiveness of repression of transnational crimes, and the improvement of the work of the security and defense agencies, without concern for the development dimension. Thus, we can infer that these are in some way limited to the issue of repression, based on a reactive approach, lacking a broader view of human security and prevention.

\section{THE ARTICULATION BETWEEN THE SPHERES OF DEFENSE AND DEVELOPMENT IN THE MANAGEMENT OF THE BORDER}

As was shown above, the borderland is a differentiated space on which diverse public policies at different levels of government are involved. In view of this, the Court of Auditors of the Union - TCU (2014) draws attention to the fact that in this region there are several organs in its management, with their own directives and multiple attributions in several lines of action, which must be carried out in a joint and cohesive manner, with adequate infrastructure, appropriate controls, and complementary purposes, in order that their actions be productive, without gaps or counterproductive efforts, and to enable common objectives to be achieved.

Among this myriad of agencies operating in the border area, in this study we call attention to the work of the Ministry of National Integration and the Ministry of Defense. In this regard, when we observe the performance of these, we find that they act together, especially with respect to the borderland. However, this interaction is often formal, existing only in regulations.

In this sense, the two ministries are members of the Permanent Commission for the Development of the Borderland (a committee that has in a way supplanted the Promotion Program for the Development of the Borderland) established by the Decree of September 8, 2010, within the Regional Development Secretariat of the Ministry of National Integration. The commission has the purpose of proposing measures and coordinating actions that aim at the development of initiatives necessary for the action of the federal government in the borderland (Neves, 2016). Therefore, we may infer that the Commission is an advance in the institutional strengthening agenda posted by the Promotion Program. The Commission is composed of several institutions: 
It is composed of eighteen ministries linked to the regional development and international integration actions, as well as the Institutional Relations Secretariat of the Presidency of the Republic and the Office of Institutional Security of the Presidency of the Republic, which bring together the necessary competencies for the materialization of plans and objectives for federal policies aimed at the borderland (TCU, 2014).

The Permanent Commission for the Development of the Borderland seeks to provide solutions to the problems generated, above all by the fragmentation and disarticulation of the public policies applied in the region. However, its effectiveness has been low. According to the report on the borderland of the Court of Auditors of the Union (2014) up to the date of the report, there had been very few meetings since the creation of the Commission. The actions of this are reserved for discussions and the field of ideas, with considerable disinterest and even a certain lack of knowledge on the part of several interviewees by the Court of Auditors of the Union ${ }^{3}$, especially those who work in the area of security. Nevertheless, this fact reinforces the conception that the actions voted for the development and integration of the borderland occupy a secondary position in the priorities of the government in relation to security actions.

This became evident from the funding of resources for the borderland, with a considerable share concentrated in the security area in detriment of actions aimed at the development and integration of the region, which restricts the number of actors involved in the network of policies that are effectively interested in these regions (TCU, 2016).

Considering that, the security and defense dimension has gained prominence in the management of the border, it is important to mention that there is a difference in the understanding of this in the National Defense Policy and in the National Policy for Regional Development. While the Defense Policy defends a plan of vivification and development in the borderland, using the strategy of presence, the

\footnotetext{
3 The Court of Auditors of the Unioninterviewed the coordinators of the Permanent Development Committee and the Integration of the Borderland - Ministry of National Integration and the Strategic Border Plan - Ministry of Defense, Justice and Finance, as well as the Department of Federal Highway Police, National Secretariat of Public Security, Federal Revenue Service of Brazil. In addition, also of the Ministry of Foreign Affairs, represented by the Assistant Secretary-General of South America, Central America and the Caribbean, by the Assistant Secretary Brazilian Communities Abroad, by the General Secretariat of Policy I, by the General Coordination of Defense Affairs, by the General Coordination of Budget and Finance and by the Internal Control Secretariat.
} 
National Policy for Regional Development identifies that the border deserves to be highlighted by its strategic importance in the greater objective of South American economic integration (Coutinho, 2015).

Thus, we can infer that the National Defense Policy, as well as the Border Strategic Plan and the National Strategy for Public Security in the Borderland, although its documents include the issue of integration, has a logic of national introspection, while the development policy is more integrative with neighboring countries.

Coutinho (2015) draws attention to the fact that in the National Defense Policy the word development appears dozens of times, as in the National Defense Strategy, almost a hundred repetitions, and in the White Paper on National Defense, there are more than 200 citations. On the other hand, in the National Policy for Regional Development, the word defense does not appear even once, nor in the Border Strategic Plan, whereas the issue of development is mentioned, which leads us to conclude that this alignment is not a legal, although a necessary requirement.

Such differences in mentality could be mitigated through meetings of the National Defense Policy, National Defense Strategy and National Defense White Paper working group since the Ministry of National Integration participates in this process (Coutinho, 2015).

Another dimension that is very evident in all the documents for the border is cooperation and integration with neighboring countries, which would complete the famous tripod of the three $D s$, Defense, Development and Diplomacy. In this sense, the deepening of cooperation would have a positive impact on the implementation of the policies defined for that territory, insofar as it facilitates the implementation of integrated actions indispensable for initiatives to promote socioeconomic development and security in the region.

However, the latest trends in security, defense, and development policies for the border show that the disarticulation between these dimensions is growing, since the agenda has been almost totally absorbed by security and defense issues, as we can observe in the process of formulating the Integrated Border Protection Program.

In an attempt to respond to the criticisms of the Court of Auditors of the Union, some of which presented in this paper, the federal government, in 2016, created a working group composed of the Ministry of Defense, the Ministry of Justice and 
the Ministry of Foreign Affairs, with the focus on cross-border flows, such as drugs, trade and arms.

The result of these works was the formulation of the Integrated Border Protection Program, established in November 2016, replacing the Strategic Border Plan, with the objective of promoting the integrated and coordinated action of public intelligence agencies, the Federal Revenue Department, the Treasury and the Armed Forces in the border regions, also involving municipal authorities and neighboring countries. It additionally provides for the reformulation of Operation Ágata.

Furthermore, the program creates an Executive Committee composed of representatives of the Institutional Security Office, the Brazilian Intelligence Agency, the Joint Chiefs of Staff of the Armed Forces, the Federal Revenue Department, the Federal Police, the Federal Highway Police, the Ministry of Justice, Public Security and Citizenship, and the General Secretariat of the Ministry of Foreign Affairs.

It is important to note that both during the formulation and in the implementation process of the Integrated Border Protection Program; the Ministry of National Integration was not called to participate, making clear the current government's vision regarding the management of the border, based much more on a negative agenda than on development and regional integration.

\section{THE DYNAMICS IN LA PLATA BASIN: THE CASE OF THE TRIPLE BORDER}

As we have seen above, there are huge differences in the understanding and disarticulation among public agencies in border management. This situation can be clearly seen in the cross-border region of La Plata Basin, since this may be considered as one of the most dynamic areas of the Brazilian border, being the logistic and geo-economic core of the Southern Common Market, especially in the cross-border region of Foz do Iguaçu, due to its regional economic importance as well as security problems. Therefore, this region imposes the challenge of how to guarantee the circulation and to protect itself from illicit activities.

The Triple Border is formed by the twin cities of Ciudad del Este (PRY), Foz do Iguaçu (BRA) and Puerto Iguaçu (ARG), which polarize an area that encompasses 
municipalities located in the Department of Alto Paraná in Paraguay; the Department of Iguazú in Argentina; and the Microregion of Foz de Iguaçu, Brazil, forming the cross-border region of Iguaçu. This regionalization was suggested by Pereira Carneiro (2016) and follows the standards of the European Union's cross-border regions, which are created from pre-existing political-administrative divisions (municipalities, states, provinces, etc.).

Unlike most of the borderland, the Triple Border is characterized by an area of strong economic dynamism, due to the tourist flow and the presence of two free zones - Puerto Iguazú and Ciudad del Este - the region polarizes the logistical nucleus which integrates the Argentine Northwest, the East of Paraguay and the West of Paraná State. Ciudad del Este is the third largest free trade zone in the world, thus being an important revenue for Paraguay. In addition, this area has a good infrastructure with airports, port and road networks.

However, due to the large volume of trade flowing through the region, there is a need to increase the local infrastructure that is why it is contemplated in the portfolio of the South American Council of Infrastructure and Planning, which incorporated the Initiative for Integration in Infrastructure of South America. The projects for the region are: the construction of the Cascavel-Foz do Iguaçu and Cascavel-Guairá-Maracaju Railway; a Railway Bridge with a cargo yard between Foz do Iguaçu and Ciudad del Este; the concession for the improvement of Highways No. 2 and 7 (Assuncíon-Ciudad del Este); the construction of the Iguaçu hydroelectric power station; and the transmission line $500 \mathrm{KW}$ (Itaipu-Assuncíon). In addition, there are complementary projects, the construction of the road ring in Foz do Iguaçu and the construction of the intermodal terminal on BR-277 (IIRSA, 2009).

In addition, the region has also become an important locus for the integration of Latin American peoples, with the foundation of the Federal University of Latin American Integration (UNILA acronym in Portuguese). The university has 57\% foreign students, as well as foreign teachers, with classes in Portuguese and Spanish, providing an environment for building a Latin American identity, but primarily a South American one.

Thus, we observe that various regional integration projects affect the region. In addition to these, the Promotion Program for the Development of the Borderland also covers the city of Foz do Iguaçu. Regarding this, there are discussions in 
the Thematic Chambers for the creation of an international border hospital; the construction of a second bridge integrating Foz do Iguaçu and Ciudad del Este, with the purpose of transporting loads. Moreover; the implementation of the Economic and Social Development Council of Foz do Iguaçu; and the integration of the airports at the Triple Border in normative and operational aspects (MI, 2017).

Thus, this is a highly integrated borderland from not only the economic as well as the social point of view. However, this integration also brings externalities; the region has become an important point in the activities of transnational criminal networks that use the local infrastructure to carry out all kinds of trafficking and smuggling, usually using small aircraft for the transportation of narcotics. The money generated by these illegal flows is "laundered" by the criminal networks in the commerce of Ciudad del Este.

Salvador Raza (2014) shows that this is a highly regulated border, with illicit transit and smuggling points, relatively effective in populated areas. The efficiency of illegal flows is due in large part to the high levels of corruption in these places, which is more serious on the Paraguayan side, a situation that has improved in recent years according to the Brazilian authorities. Another factor in this equation is that the illegal economy in Paraguay represents a large part of the country's economic activity.

In addition, the Triple Border is one of the main corridors for the international traffic of drugs and supply of the Brazilian market. After the entrance, mainly by the border with Paraguay (important producer of marijuana), this is internalized into Brazil. In addition, more recently, this space has become part of the international cocaine trafficking route. Smuggling is also intense in this area, facilitated by the porosity of borders.

In this way, the porosity of the border is seen in a negative way, generating the image of the border as a crime place, not as a space for integration. Nevertheless, in view of the growth of the political debate around the border as one of the sources of violence in large urban centers, it became the main agenda in the management of the border. In Foz do Iguaçu there was an increase in the operations carried out by all the security organs and the Internal Revenue Department, as well as operations in conjunction with the Armed Forces.

In this sense, although there are several infrastructure integration projects in the region, the implementation of these projects is low, and as discussed, the budget 
allocations for Promotion Program for the Development of the Borderland have declined significantly in recent years, while investments in security have shown an increase.

Another important aspect is the disarticulation between such initiatives as demonstrated above. While development and integration policies have a more universalist logic, of cooperation with neighboring countries, security and defense policies are based on deterrence, in other words, in the denial of access to Brazilian territory.

However, in an economic and social integrated region, such as that of Foz do Iguaçu, a security framework based on the closure of the border and national introspection is inadequate, especially since transnational crime networks act in a deterritorialized way. In this way, combating such crimes demands approaches based on cooperation with neighboring countries, as well as strategies that seek regional development, since social vulnerability on the other side of the border has impacts on both sides.

\section{FINAL CONSIDERATIONS}

Border management is indeed complex and it is a thorny terrain since it is surrounded by several divergent interests and presupposes the articulation between a vast myriad of actors at different levels of government. However, the need to create synergies is an imperative to ensure the well-being of border populations as well as to protect the country from negative flows, which often find an environment conducive to its activities in the border area.

However, the achievement of an environment conducive to interinstitutional cooperation is hampered by the way the border has been managed in Brazil. Without its own law, besides being disciplined exclusively by executive decree, government actions directed to the border are bound to the established priorities in each government, not constituting a state policy that integrates all entities and has an intergovernmental character (TCU, 2016).

In this sense, the articulation between organs of different spheres, with diverse mentalities, as exemplified above becomes even more complicated. In addition, it is important to mention that even cooperation between defense and security institutions is problematic in many ways. 
Moreover, the cooperation between the Ministry of National Integration agencies and the security sector was practically infeasible by the overlapping of the security dimension in the agenda and little emphasis on its coordination with development and integration activities. This process resulted in the incipience of formalization of plans and objectives by the Permanent Commission for the Development and Integration of the Borderland, not harmonizing the sequence of appropriate intervention to deal with problems already diagnosed through studies carried out by the Ministry of National Integration (TCU, 2014).

This discrepancy can also be observed by the allocation of resources, even though the border is an important space for integration and interconnection with the productive chains of neighboring countries, as could be observed in La Plata Basin. A number of resources applied by the federal government for development and integration, besides low materiality, has complex identification, if not infeasible, in the way it is configured in the Pluriannual Plan, as shown by the dilution of the Promotion Program for the Development of the Borderland in other headings.

However, although the previous model presented serious shortcomings, there was a certain articulation between the development and security dimension in the Committee for the Development of the Borderland, since it became the space for discussion of border issues. However, the new model established by the Integrated Border Protection Program seems to have moved further away from these spheres. Because the Ministry of National Integration did not participate in its formulation, nor does it participate in the Executive Committee of the program, which should become the main forum for articulating actions for the border, supplanting the Committee for the Development

Nevertheless, this shows a narrow understanding about the border. Because, as we could see in the case of La Plata Basin, more specifically in the transnational border region of Iguaçu, a repressive bias shows poor effectiveness in a highly integrated border, since this criminal networks function in a deterritorialized way. In this sense, policies that aim development that would bring more opportunities to the population, as well cooperation with neighboring countries could have results that are more beneficial. In addition, due to the extension of the Brazilian border, one approach could not be implemented in the whole borderland, since the realities are very distinguished.

Finally, we could observe that although development and security are interdependent, policies for Brazilian borders have neglected the issue of development, a process that seems to have deepened in the new security plan, and these are oriented almost entirely to the security bias, which evidences a myopic view of border management, since there is no security without development. 


\section{REFERENCES}

Alvarez, M. C. and Salla, F. (2013). Estado-nação, Fronteiras no Brasil: Redesenhando os Espaços Fronteiriços no Brasil Contemporâneo. Civitas 13(1), p. 9-26.

Brasil. (2011). Decreto n. 7496. Instituí o Plano Estratégico de Fronteira. Brasília, DF.

Buzan, B. (1983). People, State and Fear. Brighton: Wheatsheaf Books.

Cargnin, A. P. (2014). Política Nacional de Desenvolvimento Regional e Repercussões no Rio Grande do Sul. Mercator 13, p. 19-35.

Coutinho, W. T. Z. (2015). A Política NaRegionalcional de Defesa e a Política Nacional de Desenvolvimento. Monografia de Conclusão de Curso - Escola Superior de Guerra.

Dorfman, A. and Cardlin, E. G. (2014). Estratégias espaciais do ativismo em condição fronteiriça no Cone Sul. Cuadernos de Geografia, Bogotá, v. 23, p. 31-44.

Força Áerea Brasileira (FAB). (2013). Operação Ágata: Plano Estratégico de Fronteira. Brasília. Disponível em: <http://www.defesa.gov.br/operacao-agata/index.html>. Acessado em 20 de maio de 2015.

Iniciativa para a Integração da Infiraesturutura Sul-Americana (IIIRSA). (2009) Cartela de Projetos IIRSA.

Klingebiel, S. (2006). New Interfaces between Security and Development: changing concepts and approaches. German Development Institute.

Ministério da Integração Nacional (MI). (2017). Faixa de Fronteira: Programa de Promoção do Desenvolvimento da Faixa de Fronteira. Brasília, 2009.

Ministério da Integração Nacional (MI). (2017a). Consolidação dos Planos de Desenvolvimento e Integração das Faixas de Fronteira. Brasília.

Neves, A. J. das et al. (2016). Mapeamento das Políticas Públicas Federais na Faixa de Fronteira: interfaces com o Plano Estratégico de Fronteira e a Estratégia Nacional de Segurança Pública. Brasília: Ministério da Justiça e Cidadania. Secretaria Nacional de Segurança Pública.

Pëgo, B. et al. (2017). Fronteiras do Brasil: diagnóstico e agenda de pesquisa para política pública, volume 2. Brasília: IPEA: MI.

Polícia Federal. (2012).PF apresenta balanço de um ano da Operação Sentinela. Brasília. Disponível em: <http://www.pf.gov.br/agencia/2012/junho/pf-apresenta-balanco-de-um-ano-da-operacaosentinela>. Acessado em 01 de janeiro de 2016.

Silva, G. de V. (2013). Usos Contemporâneos da Fronteira Franco-Brasileira: Entre os Ditames Globais e a Articulação Local. Macapá: Unifap.

Tribunal de Contas da União (TCU). (2014). Auditoria Operacional. Avaliação de Governança de Políticas Públicas. Fortalecimento da Faixa de Fronteira. Análise Sistêmica das Oportunidades de Melhoria Constatadas. Recomendação aos Órgãos Responsáveis. Brasília.

Tschirgi, N. (2006). Security and Development policies: untangling the relationship. In: KLINGEBIEL, Stephan. New Interfaces between Security and Development: changing concepts and approaches. German Development Institute. 


\section{Datasheet}

\section{Editors}

\section{Antonio Paulo Cargnin}

Ph.D. in Geography by Universidade Federal do Rio Grande do Sul (UFRGS). Director of the Department of Governmental Planning (DEPLAN) of Secretaria de Planejamento, Governança e Gestão (SPGG) of Rio Grande do Sul State Government - Brazil. Fellow Professor of Programa de Pós-Graduação em Geografia (POSGEA) at Universidade Federal do Rio Grande do Sul (UFRGS).

\section{Aldomar Arnaldo Rückert}

Ph.D. in Science: Human Geography by Universidade de São Paulo (USP). Professor at Universidade Federal do Rio Grande do Sul (UFRGS). Researcher with scholarship Produtividade 2 - CNPQ. Member of the scientific committees of Collège International des Sciences du Territoire (CIST) - Université Paris I Panthéon Sorbonne and of Université Paris 7 Denis Diderot. Researcher of Laboratório Estado eTerritório (LABETER), of Programa de Pós-Graduação em Geografia (POSGEA) at Universidade Federal do Rio Grande do Sul (UFRGS).

\section{Bruno de Oliveira Lemos}

M.S. in Geography by Universidade Federal do Rio Grande do Sul (UFRGS). Geographer of technical-scientific career of Rio Grande do Sul State Government working at Secretaria do Planejamento, Governança e Gestão (SPGG). Researcher of Laboratório Estado e Território (LABETER), of Programa de Pós-Graduação em Geografia (POSGEA) at Universidade Federal do Rio Grande do Sul (UFRGS). 


\section{Alejandro Gabriel Benedetti}

Ph.D. in Geography. Independent Researcher of the scientific researcher career of Consejo Nacional de Investigaciones Científicas y Técnicas (CONICET). Professor of Department of Geography at Universidad de Buenos Aires and Instituto del Conurbano of the Universidad Nacional de General Sarmiento (Argentina). Director of Grupo de Estudios sobre Fronteras y Regiones and Editor of Revista Transporte y Territorio, at Instituto de Geografía, Universidad de Buenos Aires.

\section{Ana Maria de Aveline Bertê}

M. S. in Geography by Universidade Federal do Rio Grande do Sul (UFRGS). Geographer of the technicalscientific career of Rio Grande do Sul State Government working at Secretaria do Planejamento, Governança e Gestão (SPGG).

\section{Andressa Lopes Ribeiro}

Architecture and Urbanism student at Universidade Federal do Rio Grande do Sul (UFRGS).

\section{Eduarda Figueiredo Scheibe}

Ph.D. Student by Institut de Géographie de Paris, Université Paris I Panthéon Sorbonne with scholarship from Programa de Doutorado Pleno no Exterior of Coordenação de Aperfeiçoamento de Pessoal de Nível Superior (CAPES).

\section{Flávia Carolina de Rezende Fagundes}

Ph.D. Student in Geography by Universidade Federal do Rio Grande do Sul (UFRGS). Member of Centro de Estudos Internacionais sobre Governo (CEGOV) and of Laboratório Estado e Território (LABETER). 


\section{Heleniza Ávila Campos}

Ph.D. in Geography by Universidade Federal do Rio de Janeiro (UFRJ). Professor of Department of Urbanism at Architecture and Urbanism College at Universidade Federal do Rio Grande do Sul (UFRGS) and of Programa de Planejamento Urbano e Regional (PROPUR).

\section{Ludimila Losada da Fonseca}

M. S. in Geography - Territorial Analysis by Universidade Federal do Rio Grande do Sul (UFRGS). Researcher of Laboratório Estado e Território (LABETER), of Programa de Pós-Graduação em Geografia (POSGEA) at Universidade Federal do Rio Grande do Sul (UFRGS).

\section{Roberto Rodolfo Georg Uebel}

Ph.D. Student of Programa de Pós-Graduação em Estudos Estratégicos Internacionais of Universidade Federal do Rio Grande do Sul (UFRGS). Specialist in Effective Use of Energetic Resources by International Sustainable Energy Development Center under the auspices of UNESCO and by the Russian University of Friendship of People.

\section{Sébastien Velut}

Professor of at Université Paris 3 Sorbonne Nouvelle. Diretor of International Relations of Université Sorbonne Paris Cité. Studied Geography at Paris I and at Institute of Advanced Studies of Latin America, where he developed his tesis about Argentinian federalism in 2000. Director of Centre de Recherche et de Documentation sur les Amériques (CREDA) - Institut des Hautes Études de L'Amérique Latine (IHEA).

\section{Silvina Cecilia Carrizo}

Ph.D. in Geography, Territorial Planning and Urbanism by Université Sorbonne Nouvelle - Paris 3. Researcher of CONICET and of Centro de Estudios Sociales de América Latina (CESAL). 


\section{Suzana Beatriz de Oliveira}

Specialist in Environmental Geography by Universidade Federal do Rio Grande do Sul (UFRGS). Geographer of the technical-scientific career of Rio Grande do Sul State Government working at Secretaria do Planejamento, Governança e Gestão (SPGG). 
"Pierre Monbeig, the great French geographer who participated in the founding of Universidade de São Paulo (USP) used to quote a saying he had often heard in the 1930s: "Brazil grows up at night, while the politicians are sleeping". This is still true today, as the dynamism of Brazilian society often allows it not to be blocked by the weakness or ineptness of public policies.

It seems that this is also the case more widely on the continent, as shown in the book coordinated by Antonio Paulo Cargnin, Aldomar Arnaldo Rückert and Bruno de Oliveira Lemos. They had intended to identify and analyze common territorial dynamics among the countries of the region, as well as recent transformations in the multi-scale territorial policies applied to the boundaries of La Plata Basin. The cases presented in this book show precisely, in detail, the richness of current developments in these border regions, while national public policies, and even multilateral ones, are struggling to set up."

\section{Hervé Théry}

Researcher of Centre National de la Recherche Scientifique Professor of Universidade de São Paulo (USP) 